\title{
NOWA POLITYKA STRUKTURALNA W WARUNKACH OTWARTEJ GOSPODARKI RYNKOWEJ
}





\section{NOWA POLITYKA STRUKTURALNA W WARUNKACH OTWARTEJ GOSPODARKI RYNKOWEJ}

redakcja naukowa: Justin Yifu Lin i Alojzy Z. Nowak

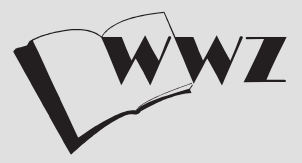

Wydawnictwo Naukowe Wydziału Zarządzania Uniwersytetu Warszawskiego
WARSZAWA 2018

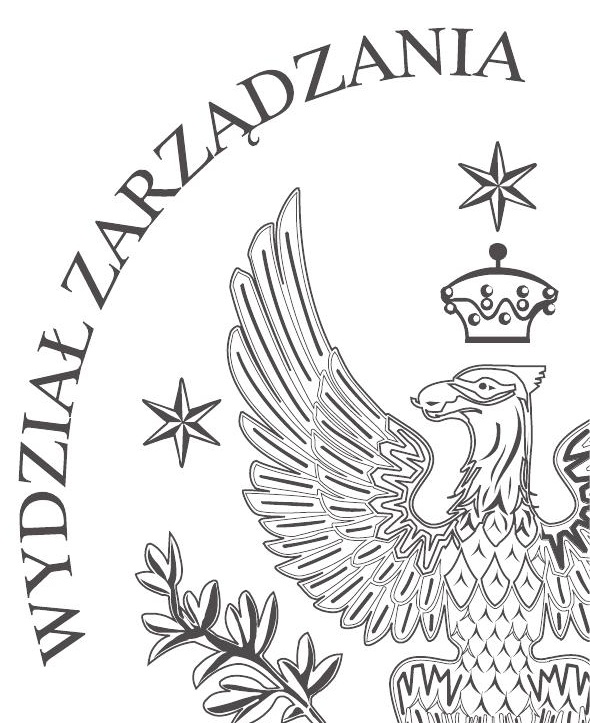


Recenzent: Prof. dr hab. Zofia Wysokińska, Uniwersytet Łódzki

Redakcja: Jerzy Jagodziński, Anita Sosnowska

Projekt okładki: Agnieszka Miłaszewicz

„Publikacja dofinansowana $z$ dotacji na utrzymanie potencjału badawczego na Wydziale Zarządzania Uniwersytetu Warszawskiego".

(C) Copyright by Wydawnictwo Naukowe Wydziału Zarządzania Uniwersytetu Warszawskiego, Warszawa 2018

ISBN: 978-83-65402-97-4

e-ISBN: 978-83-65402-93-6

https://doi.org/10.7172/978-83-65402-93-6.2018.wwz.11

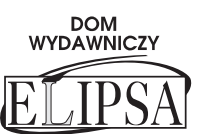

Opracowanie komputerowe, druk i oprawa:

Dom Wydawniczy ELIPSA

ul. Inflancka 15/198, 00-189 Warszawa tel. 226350301

e-mail: elipsa@elipsa.pl,www.elipsa.pl 


\section{Spis treści}

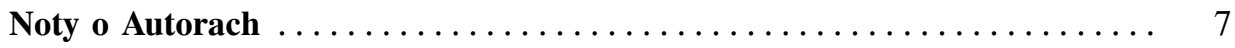

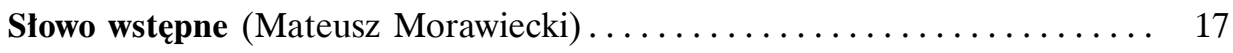

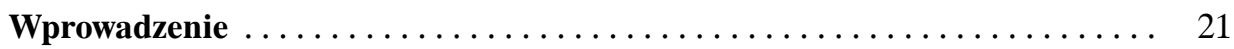

\section{CZĘŚĆ I}

\section{Alojzy Z. Nowak}

Jaka przyszłość globalnej gospodarki?

Kenneth Friedman, Ruth Taplin

Wolny handel czy niepohamowana promocja interesów narodowych

i korporacyjnych?

\section{Harald Sander}

Europa $w$ nowej ekonomii globalnej

\section{Andrzej Sopoćko}

Sekularne procesy strukturalne. Nieoczekiwane rezultaty . . . . . . . . . . . 94

Kazimierz Ryć

Kontrola kapitatu przeciw pułapce średniego dochodu

\section{CZĘŚĆ II}

\section{Justin Yifu Lin, Xiaobing Wang}

Państwo wspierajace a rozwój gospodarczy: rola państwa

w Nowej Ekonomii Strukturalnej

Grzegorz Jędrzejczak, Henryk Sterniczuk

Wykorzystanie Nowej Ekonomii Strukturalnej dla modernizacji

i zwiększenia innowacyjności polskiej gospodarki

\section{Marian Górski, Patrycja Chodnicka-Jaworska}

Proces doganiania rozwoju gospodarczego krajów OECD oraz rola bezpośrednich inwestycji zagranicznych $w$ tym procesie 


\section{Beata Kozlowska-Chyła}

Prawne otoczenie dla inwestycji zagranicznych $w$ Polsce . . . . . . . . . . . 195 Michał Kurtyka

Czy można zamienić państwa $w$ huby motoryzacyjnej innowacji? . . . . . 206 Bogdan J. Góralczyk

Polska na trasie chińskiego Jedwabnego Szlaku: szansa rozwojowa, czy wyzwanie? ............................... 221 


\section{Noty o Autorach}

Patrycja Chodnicka-Jaworska - doktor nauk ekonomicznych, adiunkt na Wydziale Zarządzania Uniwersytetu Warszawskiego w Zakładzie Bankowości i Rynków Pieniężnych, autorka i współautorka ponad 100 publikacji naukowych wydanych w językach polskim i angielskim. Uczestniczka konferencji i seminariów o charakterze naukowym, jak i branżowym (m.in. organizowanych przez STERN, University of Oxford, University of Cambridge, London School of Economics). Prowadzi badania naukowe w zakresie zarządzania ryzykiem bankowym. Należy do zespołu realizującego badania w ramach projektu „Regulacyjne determinanty procykliczności w działalności kredytowej banków”, które zostały sfinansowane decyzją Dyrektora Narodowego Centrum Nauki. Kierowniczka kilku projektów badawczych, m.in. dotyczących determinant credit ratingów instytucji finansowych i krajów, wpływu zmian credit ratingów na funkcjonowanie rynku finansowego, efektywności sektora bankowego, ryzyka upadłości sektora bankowego. Pełni funkcję członka zagranicznych komitetów naukowych czasopism oraz konferencji. Współredaktorka czasopisma naukowego Faculty of Management Working Paper Series. Członek ABSRC, IRMC, EAEPE. Uzyskała szereg nagród i wyróżnień, w tym Stypendium Ministra Nauki i Szkolnictwa Wyższego za wybitne osiągnięcia dla doktorantów (2012/2013). Laureatka Kongresów Rynku Kapitałowego oraz Konkursu XVI Konferencji Naukowej Młodych Ekonomistów.

Kenneth Friedman - profesor na Regis University, Colorado, USA, nagrodzony przez tę uczelnię za wybitne osiągnięcia pedagogiczne. Prezes Clifton Mining, firmy mikro-cap notowanej na giełdzie, która działa w branży badań metali szlachetnych oraz w branży biotechnologii.

Autor dwóch książek: Predictive Simplicity: Induction Exhum'd (1990, Pergamon) oraz Myths of the Free Market (2003, Algora Publishing), szeregu artykułów zamieszczanych w czasopismach naukowych z dziedzin fizyki i filozofii oraz redaktor działu recenzji książek w piśmie „Interdisciplinary Journal of Economics and Business Law”. Stopień doktora w dziedzinie filozofii otrzymał na M.I.T. (Massachusetts Institute of Technology po wcześniejszym zdobyciu tytułów magistra nauk ścisłych (M.S.) na M.I.T. oraz magistra nauk humani- 
stycznych (M.A.) na Uniwersytecie Harvarda. Laureat stypendium American Council of Learned Societies; przez rok studiował pod kierunkiem Ilii Prigogine'a na Wolnym Uniwersytecie w Brukseli. Przyznaje się do wpływów teorii nieliniowości.

Bogdan Góralczyk - profesor w Centrum Europejskim Uniwersytetu Warszawskiego; politolog i sinolog. Były szef Gabinetu Politycznego Ministra Spraw Zagranicznych (2001-2003) i długoletni dyplomata, m.in. w latach 2003-2008 ambasador RP w Tajlandii, na Filipinach i w Związku Mjanma (d. Birma). Od 1 września 2016 r. dyrektor Centrum Europejskiego UW. Stały komentator kanału TVN24 Biznes $i$ Świat oraz w Instytucie Obywatelskim; częsty gość radia TOK FM. Publikuje m.in. na łamach portalu NBP „Obserwator Finansowy” i wp.pl. Autor wielu książek i publikacji na temat Chin i Azji, problemów globalnych oraz Węgier, m.in.: Zmierzch i brzask. Notes z Bangkoku, Toruń 2009/2010; Chiński Feniks. Paradoksy wschodzacego mocarstwa, Warszawa 2010; Ztota Ziemia roni tzy. Esej birmański, Warszawa 2011; Przebudzenie smoka. Powrót Chin na scene globalna, Warszawa 2012; Sun Yat-sen. Misjonarz rewolucji, Warszawa 2013. Redaktor i współautor tomów: Polska-Chiny. Wczoraj, dziś, jutro, Toruń 2010 (wersja anglojęzyczna 2014); Unia Europejska jako aktor na scenie globalnej. Razem czy osobno?, Warszawa 2014 (rozszerzona wersja anglojęzyczna w przygotowaniu) oraz European Union in the Global Scene: United or Irrelevant?, Warszawa 2015.

Wykłada w kraju i za granicą. Specjalizuje się w tematyce globalnej i azjatyckiej (Chiny, Birma-Mjanma, Tajlandia, Filipiny), ale w polu jego zainteresowań znajdują się także kwestie z zakresu Protokołu Dyplomatycznego oraz różnic kulturowych (z racji wieloletniego doświadczenia dyplomatycznego i długoletnich pobytów za granicą).

Marian Górski - profesor ekonomii; kierownik Katedry Systemów Finansowych i Zakładu Bankowości i Rynków Pieniężnych na Wydziale Zarządzania Uniwersytetu Warszawskiego. Specjalizuje się w finansach, bankowości, makroekonomii, polityce pieniężnej. Autor i współautor wielu monografii i artykułów naukowych. Jego podręcznik akademicki pt. System Finansowy Gospodarki był trzykrotnie wydawany $(2007 ; 2009 ; 2013 ; 2018)$. W latach 1990-1996 dziekan Wydziału Zarządzania UW. Obecnie członek Senatu Uniwersytetu Warszawskiego, przewodniczący senackiej komisji ds. budżetu i finansów.

Był i jest związany z praktyką gospodarczą. W latach 1991-2005 członek i przewodniczący rady nadzorczej jednego z większych banków w Polsce - BZWBK S.A. Jako partner firmy consultingowej Premium-econ w latach 1991-2003 
doradzał m.in. Ministrowi Skarbu Państwa i Ministrowi Gospodarki. Aktualnie członek Rady ds. stawek referencyjnych WIBID i WIBOR, która nadzoruje rynek depozytów międzybankowych w Polsce.

Grzegorz Jędrzejczak - doktor habilitowany, profesor UW. W latach 1989-1991 Podsekretarz Stanu w Ministerstwie Przekształceń Własnościowych odpowiedzialny za stworzenie polskiego rynku kapitałowego. W latach 1993-2013 pracownik Banku Światowego w Waszyngtonie w Departamencie Rozwoju Prywatnego Sektora i Systemu Finansowego Europy i Azji Centralnej oraz przedstawiciel Banku Światowego w Ukrainie i Azerbejdżanie. Członek Rady Nadzorczej Polskiej Fundacji Badań nad Zarządzaniem oraz IBD Business School.

Od lat 80 . XX w. z powodzeniem łączy zainteresowania naukowe $\mathrm{z}$ działalnością praktyczną. Obszary jego zainteresowań obejmują: prywatyzację, tworzenie regulowanych rynków kapitałowych, powstawanie ładu korporacyjnego w Polsce i innych krajach przechodzących transformację od gospodarki planowej do gospodarki rynkowej. Ważnym obszarem jego działalności praktycznej i analitycznej były programy rozwojowe w krajach rozwijających się oraz możliwości pomocy ze strony organizacji międzynarodowych, ze szczególnym uwzględnieniem Banku Światowego. Obecnie specjalizuje się w tematyce z zakresu uwarunkowań polityki gospodarczej promującej innowacyjność w krajach o średnich dochodach oraz analizy długookresowych szans i zagrożeń gospodarki polskiej.

Beata Kozłowska-Chyła - doktor habilitowany nauk prawnych; adiunkt na Wydziale Prawa i Administracji Uniwersytetu Warszawskiego w Katedrze Prawa Handlowego Instytutu Prawa Cywilnego. Członek Rady Legislacyjnej przy Prezesie Rady Ministrów. Radca prawny specjalizujący się w sprawach gospodarczych. Arbiter rekomendowany w Sądzie Arbitrażowym przy Krajowej Izbie Gospodarczej w Warszawie. Senior Counsel w Research Center for „the Belt and Road" Law, China University of Political Science and Law (CUPL). Członek zarządów i rad nadzorczych dużych spółek akcyjnych, w tym spółek z udziałem Skarbu Państwa.

Autorka kilkudziesięciu publikacji naukowych z zakresu prawa spółek, prawa papierów wartościowych, problematyki przekształceń własnościowych i prywatyzacji przedsiębiorstw oraz prawa ubezpieczeniowego, opublikowanych w renomowanych czasopismach. Członek Rady Naukowej Przeglądu Ustawodawstwa Gospodarczego oraz Rady Programowej Gazety Bankowej. W roku 2018 otrzymała Nagrodę Rektora Uniwersytetu Warszawskiego za osiągnięcia naukowe i zasługi dla rozwoju Uniwersytetu Warszawskiego. 
Michał Kurtyka - absolwent prestiżowej paryskiej uczelni Ecole Polytechnique, gdzie uzyskał w 1996 roku tytuł inżyniera. Stypendysta w zakresie optyki kwantowej, znajdującego się pod Waszyngtonem (DC), National Institute of Standards and Technologies, gdzie pracował pod przewodnictwem, laureata Nagrody Nobla z fizyki, Williama D. Phillipsa, będącego jednocześnie promotorem jego pracy dyplomowej dotyczącej warunków powstania kondensatu Bosego-Einsteiena. W trakcie studiów specjalizował się również w ekonomii, ze szczególnym uwzględnieniem organizacji rynku pod przewodnictwem profesora Jean Tirole, laureata Nagrody Nobla z ekonomii w 2014 roku. W obszarze ekonomii międzynarodowej studiował na uniwersytecie w Louvain La Neuve oraz uzyskał tytuł magistra w Szkole Głównej Handlowej w Warszawie.

Pracownik Urzędu Komitetu Integracji Europejskiej, gdzie prowadził zespół analityczny wspierający negocjacje akcesyjne z Unią Europejską w zespole Głównego Negocjatora, Jana Kułakowskiego oraz bezpośrednio zajmował się obszarem transportu i energii. Jako doradca współprowadził projekty modernizacji największych polskich firm i wspierał ich dostosowanie do wyzwań rynku europejskiego. Promotor europejskiej współpracy w zakresie zmian przemysłowych i dostosowania przemysłu w Europie do wyzwań globalizacji, m.in. w ramach Europejskiego Uniwersytetu Pracy oraz Fundacji Dublińskiej.

Obronił pracę doktorską na Uniwersytecie Warszawskim. Wykładowca zarządzania zmianą, ekonomii, organizacji rynku i strategii przemysłowej na Uniwersytecie Warszawskim, Collegium Civitas, Oxford Programme On Modern Poland. Współautor koncepcji prowadzenia skutecznych zmian w przedsiębiorstwie opisanej w książce pt. Zarzadzanie zmiana. Od strategii do dziatania, jak również autor książki pt. Od restrukturyzacji do modernizacji. Opóźniona transformacja polskiego sektora elektroenergetycznego w latach 1990-2009.

Autor rządowego programu rozwoju elektromobilności w Polsce, opisanego po raz pierwszy jako koncepcja w książce we współautorstwie z prof. Leszkiem Jesieniem pt. New Electricity and New Cars (2013-2015).

Od 1 stycznia 2016 r. podsekretarz, a następnie sekretarz stanu w Ministerstwie Energii, gdzie był bezpośrednio odpowiedzialny za rozwój technologiczny oraz wprowadzanie innowacji do sektora energii, realizację polityki klimatycznej i energetycznej w sektorze paliwowo-gazowym, prowadzenie relacji międzynarodowych z państwami oraz organizacjami międzynarodowymi. Do jego obowiązków należało również nadzorowanie największych polskich Spółek Skarbu Państwa, takich jak Orlen, Lotos i PGNiG. Pomysłodawca „Planu Rozwoju Elektromobilności”. Pilotował także tworzenie ustawy o elektromobilności i paliwach alternatywnych oraz o Funduszu Niskoemisyjnego Transportu. Pełnił funkcję Przewodniczącego Komitetu Sterującego Programu Elektromobilności. 
27 kwietnia 2018 r. powołany na stanowisko Pełnomocnika ds. Prezydencji COP 24. Obecnie sekretarz stanu w Ministerstwie Środowiska.

Justin Yifu Lin - profesor i honorowy dziekan Krajowej Szkoły Rozwoju Uniwersytetu Pekińskiego. W 1986 roku uzyskał stopień doktora ekonomii na Uniwersytecie w Chicago, a w 1987 roku powrócił do Chin. Przez piętnaście lat pełnił funkcję dyrektora-założyciela Chińskiego Centrum Ekonomii Uniwersytetu Pekińskiego, którego był również profesorem. W latach 2008-2012 piastował stanowiska głównego ekonomisty i wiceprezesa Banku Światowego jako pierwszy ekonomista z kraju rozwijającego się.

Zagraniczny członek Akademii Brytyjskiej, członek Academy of Sciences for the Developing World; doktor honoris causa Uniwersytetu w Owernii.

Autor dwudziestu pięciu książek, w tym Economic Development and Transition: Thought, Strategy and Viability (2009); Demystifying the Chinese Economy (2011); New Structural Economics: A Framework for Rethinking Development and Policy (2012); The Quest for Prosperity: How Developing Countries Can Take Off (2012); Against the Consensus. Reflections on the Great Recession (2013).

Jego skłaniające do refleksji prace inspirują pracowników naukowych, studentów, decydentów oraz wszystkie osoby interesujące się gospodarką światową. Center for New Structural Economics, Uniwersytet Pekiński, Pekin, Chiny. E-mail: justinlin@nsd.pku.edu.cn

Alojzy Z. Nowak - profesor nauk ekonomicznych. Ukończył studia magisterskie w SGPiS (obecnie SGH w Warszawie), a także studia w Stanach Zjednoczonych w zakresie ekonomii na University of Illinois at Urbana - Champaign. Jest też absolwentem bankowości, finansów i rynków kapitałowych na Uniwersytecie w Exeter w Wielkiej Brytanii oraz w zakresie ekonomii na Free University of Berlin. W Antwerpii (Belgia) odbył studia w zakresie International Economics at RUCA.

W roku 1991 otrzymał nagrodę Rektora UW za pracę doktorską, a w 1996 został wyróżniony nagrodą Ministra Edukacji Narodowej za książkę pt. Banki a gospodarstwa domowe - dynamika rozwoju. Obecnie Dziekan Wydziału Zarządzania Uniwersytetu Warszawskiego. W latach 2012-2016 Prorektor UW ds. badań naukowych i współpracy. Visiting Professor na kilkunastu światowych uczelniach. Wykłada we Francji, Wielkiej Brytanii (m.in. University of Cambridge), USA, Rosji, Chinach i w Korei. Jest członkiem Rady Naukowej Instytutu Nowej Ekonomii Strukturalnej na Uniwersytecie w Pekinie. W gronie 22. wybitnych naukowców z całego świata, znajdują się między innymi czterej laureaci Nagrody Nobla z dziedziny nauk ekonomicznych: prof. Edmund 
S. Phelps z Columbia University, prof. Michael Spence z New York University, prof. Roger Myerson z University of Chicago oraz prof. Christopher Pissarides $\mathrm{z}$ London School of Economics.

Pełni wiele funkcji doradczych. Jest członkiem kilku rad nadzorczych. Wyróżnia się zaangażowaniem na rzecz działalności publicznej. Jest członkiem Kapituły Godła „Teraz Polska”, Narodowej Rady Rozwoju przy Prezydencie RP, Prezesem ogólnopolskiego Akademickiego Związku Sportowego oraz Prezesem AZS Uniwersytetu Warszawskiego. Zasiada w wielu organizacjach naukowych i radach programowych czasopism (w tym zagranicznych). Publikuje w jęz. polskim, angielskim, niemieckim i rosyjskim.

Kazimierz Ryć - profesor nauk ekonomicznych; zatrudniony na Wydziale Zarządzania Uniwersytetu Warszawskiego. Karierę naukową rozpoczął jako asystent w Katedrze Ekonomii Politycznej, kierowanej przez wybitnego polskiego ekonomistę Profesora Oskara Langego, a promotorem jego pracy doktorskiej był Profesor Włodzimierz Brus. W latach 70. XX w. odbył trzy staże naukowe we Francji na Sorbonie. Współautor zrealizowanej koncepcji popularnej motoryzacji w Polsce. Współtwórca Wydziału Zarządzania Uniwersytetu Warszawskiego - najstarszego wydziału biznesu w Polsce, pierwszego w Europie Środkowo-Wschodniej. Ekspert w Komisji ds. Reformy Gospodarczej; kierownik Zakładu Gospodarki Rynkowej.

Wielokrotny prodziekan i dziekan Wydziału Zarządzania Uniwersytetu Warszawskiego. Obecnie wykłada makroekonomię, politykę makroekonomiczną i sektorową oraz politykę społeczną. Opiekuje się przewodami doktorskimi, prowadzi badania naukowe $\mathrm{w}$ dwóch obszarach: makroekonomii i sektora ochrony zdrowia. Autor wielu publikacji z zakresu zmian dynamiki struktury konsumpcji, polityki przemysłowej oraz problemów polityki makroekonomicznej w warunkach integracji ponadnarodowej i globalizacji.

Harald Sander - profesor ekonomii i gospodarki międzynarodowej na Politechnice Kolońskiej (Technische Hochschule (TH) Köln), gdzie powierzono mu także prowadzenie Katedry Jeana Monnet „Europa w Ekonomii Globalnej”. Dyrektor Institute of Global Business and Society na Politechnice Kolońskiej i współzałożyciel GlobalMBA - programu dla absolwentów, realizowanego we współpracy pomiędzy Politechniką Kolońską, Uniwersytetem Warszawskim i Uniwersytetem North Florida, USA. Profesor ekonomii w Maastricht School of Management (Holandia).

Autor wielu artykułów publikowanych w czołowych czasopismach, takich jak „Journal of International Money and Finance”, „Journal of Banking and 
Finance”, „Journal of Financial Stability”, „Applied Economics”, „Economic Letters”, „Economic Systems”, „Comparative Economic Studies”, „Quarterly Review of Economics and Finance”, „South African Journal of Economics”, „Credit and Capital Markets” oraz „Journal of International Financial Markets”, „Institutions and Money”. Autor lub współautor książek, m.in. Integrating Europe's Retail Banking Markets: Where Do We Stand? (2007); Consumer Credit in the Eurozone: Evidence on the Emergence of a Single Eurozone Retail Banking Market (2002) oraz Kapitalbildung, Finanzmärkte und Beschäftigung. Eine vergleichende Studie makroökonomischer Analysekonzepte (1986). Współredaktor książek, m.in. World Trade after the Uruguay Round. Prospects and Policy Options for the 21st Century (1996) i Economic and Corporate Restructuring. Experiences and Challenges of the Decade (1996). Wspólautor podręczników akademickich, takich jak: Handbook of Competition in Banking and Finance (2017); Handbook of Environmental and Sustainable Finance (2016) oraz The Encyclopedia of Central Banking (2015). Członek zespołu redakcyjnego czasopisma „Finance Research Letters" i członek redakcyjnego komitetu doradczego czasopism „Journal of Banking and Financial Economics”, „Foundations of Management” oraz „Yearbook of Polish European Studies”. Badacz wizytujący przy Dziale Badań Międzynarodowego Funduszu Walutowego (1986-1987, 1989), Contemporary Europe Research Centre na Uniwersytecie Melbourne (2002) i Global Business Institute na Uniwersytecie Nowojorskim (2006) oraz zewnętrzny badacz stowarzyszony przy Graduate School of Business and Economics na Uniwersytecie w Maastricht (2003). Wyróżniany grantami i stypendiami Unii Europejskiej, Deutsche Forschungsgemeinschaft, Rządu Kraju Związkowego Nadrenia Północna - Westfalia, Centre for European Policy Studies, European Credit Research Institute oraz Instytutu Goethego.

Andrzej Sopoćko - profesor od 1994 r. (tytuł nadany przez Prezydenta RP); zatrudniony na Wydziale Zarządzania Uniwersytetu Warszawskiego oraz w Polskiej Akademii Nauk. Jeden z twórców polskiej transformacji ustrojowej początku lat 90 . Wiodąca postać w procesie tworzenia ustawy antymonopolowej i Urzędu Ochrony Konkurencji i Konsumenta. Prezes UOKiK w latach 1995-1997. Odegrał znaczącą rolę przy powstawaniu Giełdy Papierów Wartościowych (na początku jako Member of Board, a następnie, w latach 2003-2006, jako wiceprezes). Główny doradca ekonomiczny premiera, wiceminister finansów (w latach 2001-2003).

Autor licznych (ok. 150, w tym 8 książek) publikacji. Odbywał staże zagraniczne - trzykrotnie w RFN, trzykrotnie w USA, w Szwajcarii, w Rosji. Laureat nagród i wyróżnień: trzykrotnie nagrodzony przez Polską Akademię Nauk za najlepszą 
książkę roku w zakresie nauk społecznych oraz czterokrotnie - przez Ministra Nauki.

Wychował dwoje dzieci i trzy psy.

Henryk Sterniczuk - profesor zarządzania i biznesu międzynarodowego w University of New Brunswick w Kanadzie. Wieloletni dyrektor MBA w University of New Brunswick i profesor Wydziału Biznesu w The Pensylwania State University w USA. W latach 90. XX w. doradca Ministra Przekształceń Własnościowych i założyciel Centrum Prywatyzacji w Polsce, Instytutu Prywatyzacji i Zarządzania w Rosji oraz Międzynarodowego Instytutu Biznesu na Ukrainie, Białorusi i Kazachstanie. Przewodniczący Rady Nadzorczej Polskiej Fundacji Badań nad Zarządzaniem oraz Przewodniczący Rady Naukowej IBD Business School.

Jego zainteresowania naukowe to m.in. uwarunkowania społeczne i kulturowe procesu generowania innowacji w post-industrialnych społeczeństwach innowacyjnych.

Autor i redaktor naukowy obszernej monografii pt.: Nadzór korporacyjny, która kompleksowo przedstawia najważniejsze zagadnienia dotyczące kształtowania w Polsce zasad ładu korporacyjnego i dobrych praktyk w spółkach.

Ruth Taplin - profesor, dyrektor Centre for Japanese and East Asian Studies (Ośrodka Studiów Japonistycznych i Wschodnioazjatyckich), który w roku 2000 zdobył w Wielkiej Brytanii tytuł Eksportera Roku jako partner handlowy i poszukiwacz nowych rozwiązań. Stopień doktora uzyskała w London School of Economics; posiada także stopień GDL (świadectwo ukończenia studiów podyplomowych) w dziedzinie prawa. Jest autorka/redaktorką 21 książek i ponad 200 artykułów. Przez 9 lat jako niezależny autor pisywała dla dziennika „The Times” artykuły na tematy Japonii, Tajwanu i Korei; przez 9 lat była także konsultantką Federation of Electronics Industry (Federacji Przemysłu Elektronicznego). Ponad 20 lat temu na Uniwersytecie w Durham studiowała japonistykę jako część specjalnego kursu dla przyszłych wykładowców w Wielkiej Brytanii zajmujących się problematyką Japonii.

Autorka książek: Decision-making and Japan - A study of Japanese decisionmaking and its relevance to Western companies (1995, The Japan Library; 2003, Routledge); Exploiting Patent Rights and a New Climate for Innovation in Japan (2003, Intellectual Property Institute); Valuing Intellectual Property in Japan, Britain and the United States (2004, Routledge Curzon); Risk Management and Innovation in Japan Britain and the United States (2012, Routledge) oraz Japanese Telecommunications Market and Policy in Transition (2005, Routledge/Curzon); 
Innovation and Business Partnering in Japan, Britain and the United States (2006, Routledge); Outsourcing and Human Resource Management - An International Survey (2008, Routledge); Intellectual Property and the New Global Japanese Economy (2009, Routledge); Intellectual Property, Innovation and Management in Emerging Economies (współredaktor z Alojzy Z. Nowak) (2010, Routledge); Future Developments in the Japanese Exchanges w: Handbook of World Stock Derivative and Commodity Exchanges (czerwiec 2010, Mondo Visione). W lipcu 2009 r. przebywała z wizytą badawczą w Japonii i napisała raport na temat przyszłości japońskich papierów wartościowych i obracających nimi giełd.

W styczniu 2010 r. została wybrana przez wydawnictwo Routledge autorką miesiąca za całokształt swoich studiów azjatyckich. Jej kolejne książki wydane przez Routledge to: Mental Health Care in Japan, 2012; Intellectual Property Valuation and Innovation: towards global harmonization, 2013; Managing Cyber Risk in the Financial Sector: lessons from Asia, Europe and the USA, 2016; Innovation, Investment and Intellectual Property in South Korea: Park to Park, 2018. Ze względu na swoje doświadczenie przedsiębiorcze na polu innowacji bywa zapraszana przez ONZ do prac w roli eksperta.

Wydawca czasopisma „Journal of Interdisciplinary Economics” od 20 lat, obecnie również redaktor naczelny założonego przez siebie czasopisma „Interdisciplinary Journal of Economics and Business Law" (www.ijebl.co.uk). W roli profesora wizytującego lub zaproszonego wykładowcy wykładała na wielu uczelniach międzynarodowych, takich jak Uniwersytet w Osaka City, Uniwersytet Warszawski (Wydział Zarządzania), Uniwersytet w Bombaju (styczeń 2007) oraz Uniwersytet Bacheshir w Stambule (styczeń 2008/kwiecień 2009). W roku 2014 Ruth Taplin wykładała w Nepalu, a w roku 2018 pełniła funkcję głównego wykładowcy na konferencji MBALI, prowadząc także szereg seminariów i warsztatów na kilku uniwersytetach w Republice Południowej Afryki. Pracowała też przy realizacji indywidualnych projektów dla kilku kancelarii prawnych, specjalizujących się w tematyce praw własności intelektualnej na świecie.

Xiaobing Wang - starszy wykładowca (profesor nadzwyczajny) na Wydziale Ekonomii Uniwersytetu w Manchesterze. Tytuł doktora otrzymał w prestiżowej King's College London, a stopnie magisterskie w London School of Economics i na University of Birmingham. Jego badania dotyczą problematyki wzrostu gospodarczego i rozwoju, zmian strukturalnych oraz ekonomii Chin, ze szczególnym uwzględnieniem chińskich modeli rozwoju i dystrybucji dochodów.

Ma bogate doświadczenie w mediach, jest częstym komentatorem chińskiej gospodarki oraz szerokiego spektrum globalnych problemów gospodarczych, takich jak globalna nierównowaga i programy pomocowe w Afryce. 



\section{Słowo wstępne}

Ile wolnego rynku, a ile interwencjonizmu w gospodarce? To pytanie zadaje sobie dzisiaj nie tylko wielu ekonomistów, lecz także przywódców politycznych odpowiedzialnych za kwestie rozwojowe w większości krajów świata. Wiemy już, że uproszczona alternatywa „albo rynek, albo państwo” jest fałszywa. Polska ma w tym względzie bogate doświadczenie. Zero-jedynkowe podejście do teorii ekonomicznych spowodowało, że Polska na początku lat 90. ubiegłego wieku weszła w model rozwojowy opracowany przez państwa zachodnie. Model ten, choć niewątpliwie zdrowszy niż gospodarka centralnie planowana, nie uwzględniał specyfiki historycznej i społecznej Europy Środkowo-Wschodniej, w tym Polski. Fundament, na którym budowaliśmy dotychczas polski kapitalizm i dobrobyt stanowił zbiór reguł tzw. konsensusu waszyngtońskiego, który nie doceniał brzemienia postkomunistycznej rzeczywistości. Klasyczna teoria neoliberalna nie sprawdziła się zresztą w pełni także w wielu innych krajach Europy Środkowej i regionach świata. Jednak przez wiele lat była ona postrzegana jako nienaruszalny aksjomat, co uniemożliwiało dostosowanie rzeczywistych potrzeb rozwojowych do prowadzonej polityki.

Dopiero światowy kryzys gospodarczy, który zaczął się w 2007 roku, dał impuls do rewizji powszechnie uznawanych teorii ekonomicznych. Polska po 26 latach od dokonania transformacji ustrojowej i gospodarczej oraz po ponad 11 latach swojego członkostwa w Unii Europejskiej stanęła przed niełatwym wyzwaniem korekty swojej polityki gospodarczej poprzez opracowanie nowej strategii rozwojowej. Takiej, która z jednej strony odpowie na kluczowe, wewnętrzne oczekiwania i aspiracje społeczne. $\mathrm{Z}$ drugiej zaś - dostosuje polski wzorzec rozwoju do wymagań zewnętrznych współczesnej gospodarki światowej.

Polską odpowiedzią na obecne globalne wyzwania gospodarcze i społeczne są koncepcje zawarte w Planie Odpowiedzialnego Rozwoju. Jedną z największych wad prowadzonej po 1989 r. transformacji polityki gospodarczej był brak synchronizacji pomiędzy celem, jakim był wzrost krajowego PKB, a wzrostem zamożności wszystkich grup społecznych w Polsce. Realizowany model rozwoju nie uwzględniał także pogłębiających się strukturalnych różnic regionalnych. 
Wysoki wzrost gospodarczy często nie przekładał się wystarczająco na dobrobyt polskich obywateli i gospodarstw domowych, co skutkowało rozczarowaniem, wykluczeniem i polaryzacją społeczną, uderzając długofalowo w tempo i jakość polskiego rozwoju. Jedną z odpowiedzi na te wyzwania musiała być przemyślana i realnie wspierająca obywateli polityka społeczna, realizowana przy zachowaniu szczególnej troski o stabilność finansów publicznych i tempo wzrostu.

Choć nie powinniśmy kopiować cudzych rozwiązań systemowych, to naszym obowiązkiem jest śledzić poglądy oraz teorie ekonomistów i praktyków gospodarczych, aby móc modernizować państwo w sposób ciagły, przy zachowaniu najwyższych standardów. W polskich warunkach, w których przez wiele lat niepodzielnie rządziły rozwiązania dogmatycznie neoliberalne, na szczególne zainteresowanie zasługują te teorie, które uzupełniają tezę wstępnego warunku wzrostu gospodarczego, jakim jest sprawna gospodarka rynkowa, o rolę państwa w budowaniu fundamentów trwałości i stabilności tego wzrostu, także dzięki polskim tradycjom republikańskim oraz doświadczeniom solidarności i solidaryzmowi. Taką ciekawą doktrynę prezentuje m.in. Nowa Ekonomia Strukturalna, której czołowym autorem jest chiński ekonomista i były wiceszef Banku Światowego, Justin Yifu Lin. W pewnym uproszczeniu należy stwierdzić, że główne założenia tej doktryny pokazują pułapki i bariery trwałego wzrostu, przed jakimi stają kraje rozwijające się, które zbliżają się już do statusu krajów rozwiniętych. Co jednak ważniejsze, pokazuje ona rozwiązania i recepty pozwalające na przebicie się przez pułapkę średniego rozwoju i realne dogonienie najbogatszych państw. Polskim przykładem realizacji tej doktryny jest właśnie Plan Odpowiedzialnego Rozwoju, która również podkreśla istotność połączenia wydajnego i konkurencyjnego systemu rynkowego z państwem umożliwiającym ułatwienie strukturalnych zmian gospodarczych.

Dlatego należy docenić fakt, iż obecna publikacja, nawiązująca tematycznie do poprzedniej, wydanej w 2017 r. przez Wydawnictwo Naukowe Wydziału Zarządzania Uniwersytetu Warszawskiego pod redakcją Justina Yifu Lina oraz Alojzego Z. Nowaka - dziekana Wydziału Zarządzania Uniwersytetu Warszawskiego, kontynuuje badania i refleksję nad ważną tematyką procesów globalizacji i wniosków z nich wypływających dla takich państw, jak Polska. Nowa Ekonomia Strukturalna to nie tylko czysta teoria. Justin Yifu Lin, propagując ją, opiera się na doświadczeniach empirycznych, bada różnice i doświadczenia krajów, które osiągnęły sukces gospodarczy, nie podążając klasyczną drogą neoliberalizmu.

Wiemy doskonale, że nie opłaca się ulegać gospodarczym dogmatom - nawet tym najbardziej kuszącym. Trzeba natomiast analizować, badać, a także prezentować różne punkty widzenia w sprawach tak istotnych dla polityki gospodarczej, jak perspektywy globalizacji czy możliwe modele polityki rozwojowej. 
Wybór właściwej drogi zależy od wielu zmiennych charakterystycznych dla każdego z państw. Warto poznawać nowe pomysły, teorie i praktyki gospodarcze, bo w świecie - który zmienia się w galopującym tempie - elastyczność podejścia stanowi jeden z głównych atutów rozwojowych.

Mateusz Morawiecki

Prezes Rady Ministrów 



\section{Wprowadzenie}

Niniejsza, druga już dwujęzyczna publikacja pt. New Structural Policy in an Open Market Economy (Nowa Polityka Strukturalna a ekonomia globalnego rynku) pod redakcją Justina Yifu Lina i Alojzego Z. Nowaka jest kontynuacją tematyki zaprezentowanej w książce wydanej w roku 2017 przez Wydawnictwo Naukowe Wydziału Zarządzania Uniwersytetu Warszawskiego pt. New Structural Economics For Less Advanced Countries (Nowa Ekonomia Strukturalna wobec krajów mniej zaawansowanych). Rozważania i badania wokół koncepcji Nowej Ekonomii Strukturalnej na Wydziale Zarządzania Uniwersytetu Warszawskiego zawdzięczamy w dużej mierze obecności w Polsce i na Wydziale jednego z jej teoretyków i twórców, Profesora Justina Yifu Lina, doradcy rządu chińskiego w zakresie rozwoju gospodarczego oraz wiceprezydenta i głównego ekonomisty Banku Światowego w latach 2008-2012.

W Polsce potrzeba analitycznej oceny filozofii i praktyki rozwoju. Oparcie jej na założeniach Nowej Ekonomii Strukturalnej wydaje się tym bardziej uzasadnione, że polityka i założenia strategiczne obecnego polskiego rządu premiera Mateusza Morawieckiego traktują niektóre wskazania tej teorii z zainteresowaniem i aprobatą. Główny program rządu, oparty na Strategii na rzecz Odpowiedzialnego Rozwoju, znajduje potwierdzenie w realizacji polityki rozwojowej, której celem jest dokonywanie takich przemian strukturalnych w gospodarce, które uruchamiają proces doganiania krajów wysoko rozwiniętych przez kraje mniej zaawansowane w rozwoju, a Polskę należy zaliczyć do tej grupy państw.

Istotę teorii Nowej Ekonomii Strukturalnej i prowadzonej wokół niej analizy prezentuje publikacja z 2017 roku, dostępna w całości na stronie internetowej Wydawnictwa Naukowego Wydziału Zarządzania Uniwersytetu Warszawskiego (http://www.wz.uw.edu.pl/portale/wydawnictwo-WZUW/wydawnictwo/ksiazki-iskrypty). W bardzo dużym skrócie, teoria ta stwierdza, że rozwój gospodarczy jest procesem przemian strukturalnych, który cechują nieustanna innowacja technologiczna i postęp przemysłowy. Zjawiska te podnoszą produktywność pracy i towarzyszą udoskonaleniom $\mathrm{w}$ dziedzinach infrastruktury i instytucji, 
co wpływa na obniżenie kosztów transakcji. Polityka przemysłowa stanowi więc dla rządów niezbędne narzędzie, pozwalające wytyczać priorytety w zakresie wykorzystania ograniczonych zasobów, co pozwala z kolei na stymulację obu tych zjawisk: innowacji technologicznej i postępu przemysłowego, poprzez rozwiązywanie nieodłącznych problemów uzewnętrzniania i koordynacji w ramach przemian strukturalnych.

Oddawana właśnie do rąk Czytelników publikacja składa się z dwóch części. Jej Redaktorzy uznali, że obecne dylematy rozwoju gospodarczego warto prześledzić wraz z procesami zachodzącymi w warunkach globalizacji. Już dziś wydaje się całkowicie uzasadnione, aby do rozwikłania wielu problemów występujących w skali globalnej poszukiwać nowych rozwiązań systemowych, a może i podjąć próbę refleksji nad potrzebą nowego ładu i bardziej sprawiedliwego porządku ekonomicznego na świecie. Wydaje się to zadaniem niełatwym, można rzec karkołomnym, ale próbować warto. Na pewno koncepcja Nowej Ekonomii Strukturalnej wychodzi naprzeciw wielu dylematom rozwojowym, ale również i wątpliwościom, np. dotyczącym skali, roli i charakteru zaangażowania państwa w procesy rozwoju gospodarczego.

W części pierwszej sygnalizowanej tu książki podjęto rozważania i analizy związane z charakterem niewątpliwej ewolucji paradygmatów dotyczących gospodarki światowej i handlu światowego. Dominuje pogląd, że zarówno finansyzacja gospodarki światowej, będąca w dużej mierze rezultatem niekontrolowanych dostatecznie rynków finansowych, jak i bardzo dotkliwe dla społeczeństw skutki kryzysów przyczyniły się m.in. do zakwestionowania modelu rozwojowego opartego głównie na niekontrolowanych rynkach, bez należytego wsparcia regulacyjnego i jakiejś formy nadzoru ze strony państwa lub organizacji ponadnarodowych. Istnieje coraz powszechniejsze przekonanie, że na obecnym etapie globalizacja oparta na neoliberalnych zasadach (według konsensusu waszyngtońskiego) powinna zostać gruntownie przemyślana. Ale w jakim kierunku powinny nastąpić korekty lub zmiany obecnego stanu rzeczy? I czy pomysł taki jest w ogóle realistyczny?

Wobec tych niepewności warto najpierw zadać pytanie, jak może wyglądać najbliższa i dalsza perspektywa globalnej gospodarki. O tym, ale też o tym, gdzie szukać dodatkowych impulsów rozwojowych dla Polski traktuje artykuł Alojzego Z. Nowaka, pt. Jaka przysztość globalnej gospodarki?. W pewnych segmentach polityki gospodarczej już obecnie korzysta ona ze wskazań Nowej Ekonomii Strukturalnej. Autor tego artykułu wyraźnie podkreśla, że jednak to Unia Europejska jest organizacją, która może i powinna w większym stopniu stanowić punkt odniesienia dla integracji gospodarczej i społecznej, a przez to szerzej - dla globalnego ładu. Dla Polski stanowi to jeden z kluczowych wniosków. 
W nurcie tej tematyki zaprezentowane zostały stanowiska w artykułach Kennetha Friedmana i Ruth Taplin oraz Haralda Sandera. W artykule pt. Wolny handel czy niepohamowana promocja interesów narodowych $i$ korporacyjnych Kenneth Friedman i Ruth Taplin stwierdzają, że w zakresie oceny roli wolnego handlu w zglobalizowanym świecie mamy do czynienia z rozziewem pomiędzy teorią i praktyką. Teza ta dotyczy w szczególności neoklasycznej interpretacji wolnego handlu i jej faktycznego znaczenia w praktyce. Ich analiza wskazuje na konieczność zachowania umiaru. Z jednej strony, jak piszą, nie jest właściwe aprobowanie handlu wolnego bez ograniczeń, typowe dla podejścia laissez faire. $\mathrm{Z}$ drugiej zaś - nie da się również obronić postaw autarkii ani agresywnej, merkantylistycznej promocji własnych interesów narodowych lub korporacyjnych. Ponadto, w relacjach tych ważną rolę odgrywają aktywa niematerialne, takie jak prawa własności intelektualnej i ocena ich wartości w kontekście globalizacji.

Harald Sander w artykule pt. Europe in the New Global Economy podkreśla, że po niemal trzydziestoletnim okresie hiperglobalizacji, od czasu światowego kryzysu finansowego z lat 2008-2009 światowy proces integracji ekonomicznej stracił impet. Zdaniem autora, ogłaszanie śmierci globalizacji byłoby przedwczesne, natomiast proces globalizacji zmienia swój charakter. Głównymi cechami „nowej ekonomii globalnej” są: cyfryzacja, powstawanie i szybki wzrost firm „superstar”, rozwój gospodarek wschodzących oraz przemiany w geografii globalnych finansów. Jednocześnie, konsekwencje dystrybucyjne zarówno hiperglobalizacji w dawnej postaci, jak i zasadniczych struktur nowej ekonomii globalnej grożą osłabianiem lub nawet utratą wsparcia politycznego dla globalizacji i wiążą się ze wzrostem fali populizmu w krajach rozwiniętych. Wśród czynników kształtujących przyszłość Europy z pewnością znajdą się następstwa nowego wcielenia globalizacji i polityczne reakcje na nią. Wnioski z zawartych w artykule rozważań przekonują, że globalizacja nie jest procesem zdolnym samoczynnie podtrzymywać swój rozwój. Gdyby nie zarządzać globalizacją i jej konsekwencjami dystrybucyjnymi, proces ten przejawiałby tendencje do podważania własnych podstaw, czyli wiary w wolne, otwarte rynki, społeczeństwa i granice.

Andrzej Sopoćko w artykule pt. Sekularne procesy strukturalne. Nieoczekiwane rezultaty dokonuje analizy najważniejszych procesów kształtujących obecny system wytwarzania i podziału - globalizacji, sekurytyzacji, cyfryzacji i sztucznej inteligencji. Opisuje i analizuje ich skutki, szczególnie w dużych korporacjach. W konkluzji pisze: „przemiany społeczne wydają się obecnie zmierzać ku dwubiegunowemu społeczeństwu, czyli takiemu, w którym istnieje grupa bogatych i reszta, bynajmniej nie uboga, jednak oddzielona od tej pierwszej istotnym przedziałem dochodów. Oznacza to redukcję klasy średniej (w statystycznym 
ujęciu), która w odróżnieniu od poprzednich epok staje się coraz mniej znacząca dla rozwoju cywilizacyjnego. Główną siłą sprawczą tego procesu jest trwająca obecnie rewolucja cyfryzacji i automatyzacji”.

$\mathrm{Z}$ kolei Kazimierz Ryć w artykule pt. Kontrola kapitału w putapce średniego dochodu uważa, że w wielu gospodarkach narodowych dominują zagraniczne korporacje, które lokują w tych krajach pracochłonne procesy produkcji, korzystając z taniej siły roboczej. Podrzędną rolę miejscowej produkcji wzmocnił proces globalizacji. Gospodarki takie mogą znaleźć się w pułapce średniego rozwoju, a obecnie funkcjonują w swoistej niższej lidze gospodarki światowej. Kluczowe twierdzenie Kazimierza Rycia brzmi: „podrzędna rola miejscowych podwykonawców wynika $z$ tego, że nie partycypują oni we własności kapitałowej firm i tym samym mają mały wpływ na władzę międzynarodowych korporacji. Poprawa ich pozycji wymaga aktywnej polityki państw, w tym również w zakresie kontroli struktury przepływu kapitału w ujęciu brutto".

Drugą część książki otwiera artykuł Justina Yifu Lina i Xiaobing Wanga pt. Państwo przyjazne a rozwój gospodarczy. Rola Nowej Ekonomii Strukturalnej. Autorzy pogłębiają analizę koncepcji rozwoju i roli państwa w rozwoju gospodarczym oraz ich wpływ na przemiany instytucjonalne właśnie z punktu widzenia Nowej Ekonomii Strukturalnej. Podtrzymują tezę, że struktury ekonomiczne - włącznie ze strukturą techniki i przemysłu oraz infrastruktury twardej i miękkiej - mają charakter endogeniczny względem struktury uposażenia, która jest dana w każdej konkretnej chwili i zmienna w czasie. Opowiadają się za rolą państwa w zakresie ułatwiania przemian strukturalnych poprzez wykorzystanie polityki przemysłowej do naprawiania niedomagań rynku. Działania takie winny wspomagać branże przemysłu cechujące się ukrytymi przewagami komparatywnymi i ułatwiać im zyskanie konkurencyjności na rynku. Państwo powinno wykorzystywać swoje ograniczone zasoby i zdolności wdrożeniowe w sposób pragmatyczny, przyznając priorytet tworzeniu enklaw o korzystnej infrastrukturze i rozwijaniu instytucji, aby pobudzać dynamiczny wzrost w krajach o zasadniczo ubogiej zastanej infrastrukturze i sieci instytucjonalnej. W każdej publikacji Autorzy udowadniają więc za pomocą nowych badań i argumentów tezę o zaletach i korzyściach Nowej Ekonomii Strukturalnej.

Do założeń i praktycznych wskazań Nowej Ekonomii Strukturalnej nawiązuje także artykuł Grzegorza Jędrzejczaka i Henryka Sterniczuka pt. Wykorzystanie Nowej Ekonomii Strukturalnej dla modernizacji i zwiększenia innowacyjności polskiej gospodarki. Autorzy stwierdzają, że w ostatecznym rozrachunku decydujące znaczenie dla sukcesu modernizacyjnego Polski będzie miało promodernizacyjne nastawienie przedsiębiorców, pracowników i konsumentów (a więc całego społeczeństwa). Ich zdaniem aparatura Nowej Ekonomii Strukturalnej może 
być pomocna we wzmocnieniu roli państwa w stawianiu czoła wyzwaniom stojącym przed polską gospodarką, trzeba jednak mieć świadomość, że zastosowanie NES może zderzyć się z wieloma istotnymi wyzwaniami i ograniczeniami. Po pierwsze, duże firmy potrzebne do tworzenia innowacyjnej koalicji rozwojowej są własnością albo korporacji zagranicznych, albo państwa. Po drugie, jedynie nieliczne polskie małe i średnie firmy są w stanie podjąć wysiłek konkurencji globalnej. Po trzecie, społeczeństwo, a w tym i przedsiębiorcy odnoszą się nieufnie do instytucji państwa, a państwo z dużą nieufnością podchodzi do przedsięwzięć publiczno-prywatnych. I wreszcie po czwarte, Polacy po latach niedoboru chcą raczej konsumować niż oszczędzać, tym samym nie są podatni na obietnice poprawy przyszłego poziomu życia w zamian za zdyscyplinowane służenie interesom państwa i korporacji.

Marian Górski i Patrycja Chodnicka-Jaworska w artykule pt. Rola bezpośrednich inwestycji zagranicznych $w$ procesie doganiania rozwoju gospodarczego krajów $O E C D$ na przykładzie tych krajów dowodnie potwierdzają, że choć bezpośrednie inwestycje zagraniczne nie są ani jedynym, ani nawet głównym czynnikiem wpływającym na wzrost gospodarczy czy tempo wzrostu gospodarczego, to jednak ich napływ pozytywnie oddziałuje na tempo wzrostu gospodarczego, a z kolei wzrost gospodarczy zachęca inwestorów zagranicznych do inwestowania. Oznacza to, że inwestycje zagraniczne działają procyklicznie. Wspomagają one wzrost gospodarczy, ale również pogłębiają recesje i spadek PKB. Jeżeli zahamowanie bądź spadek tempa wzrostu gospodarczego następuje na skutek szoków wewnętrznych lub zewnętrznych, to reakcja inwestorów zagranicznych pogłębia ten spadek. Zjawisko to bardzo wyraźnie wystąpiło w roku 2018 w wypadku Argentyny i Turcji.

Beata Kozłowska-Chyła z Wydziału Prawa i Administracji Uniwersytetu Warszawskiego szerzej analizuje Prawne otoczenie dla inwestycji zagranicznych $w$ Polsce. Autorka nawiązuje m.in. do wprowadzonej w Polsce Konstytucji Biznesu i konkluduje: „wprowadzone zmiany normatywne w krajowym porządku prawnym w obszarze tworzącym organizacyjnoprawne warunki dla inwestycji zagranicznych na terytorium RP, poprzez przejrzystość i spójność regulacyjną, powinny przyczynić się do zmniejszenia barier wejścia kapitału zagranicznego na polski rynek. Polski ustawodawca wdraża w tym zakresie unijną dyrektywę usługową, a stworzone warunki prawne mają sprzyjać mobilności kapitału oraz intensyfikacji współpracy gospodarczej z przedsiębiorcami zagranicznymi. Przeprowadzona w ostatnim czasie gruntowna reforma polskiego prawa gospodarczego, dokonywana w celu poprawy sytuacji prawno-gospodarczej przedsiębiorcy oraz ułatwienia relacji przedsiębiorca - państwo, powinna również wpłynąć na zwiększenie atrakcyjności rynku polskiego dla inwestorów zagranicznych”. 
Jeszcze gdzie indziej szanse rozwojowe dla Polski widzi Michał Kurtyka. Autor, a także członek rządu polskiego, konsekwentnie twierdzi, że sprawą niezwykle ważną jest poszukiwanie nowych impulsów rozwojowych mogących stać się wartością dodaną dla gospodarek. Michał Kurtyka od dawna przekonuje do zalet i korzyści płynących z elektromobilności. Teraz, na przykładzie tejże elektromobilności, proponuje pięć czynników sukcesu dla rozwoju przemysłu samochodowego, w zależności od sytuacji państwa. Są to: siła tradycyjnych firm samochodowych, oczekiwania społeczne, potencjał kreacji miejsc pracy, możliwości umiędzynarodowienia i zdolność do inkubacji nowych podmiotów. Ze wstępnej analizy, wymagającej dalszej rozbudowy i weryfikacji wynika, że państwa, takie jak Chiny, wydają się już na starcie znajdować w uprzywilejowanej pozycji, aby najbardziej skorzystać z potencjału nowej mobilności.

Z taką diagnozą dotyczącą Chin mógłby się zgodzić Bogdan Góralczyk - profesor w Centrum Europejskim Uniwersytetu Warszawskiego, politolog i sinolog. W artykule pt. Polska na trasie chińskiego Jedwabnego Szlaku. Szansa rozwojowa, czy wyzwanie? Pokazuje on, jak do tego projektu odnoszą się kolejno elity państw Unii Europejskiej, regionu Europy Środkowo-Wschodniej objętej inną chińska strategią $16+1$ oraz w Polsce, która bezpośrednio na tym szlaku się znalazła. Co z tą szansą Polska zrobiła? Z analizy wynika, że stosunkowo niewiele - pomimo zauważalnej chińskiej obecności i interesów tu lokowanych. Jedwabne szlaki pozostają więc dla Warszawy raczej bardziej niewykorzystaną i potencjalną niż realną nową szansą rozwojową. Aby to zmienić, potrzebna jest polityczna wola, której po polskiej stronie brak. Być może na razie brak.

$$
* * *
$$

Druga z serii dwujęzyczna publikacja w naszym zamierzeniu ma pobudzić do dyskusji na zawarte w niej tematy także za granicą. Nie brakuje w niej poglądów i zdań zasługujących właśnie na pogłębione studia oraz różnych punktów widzenia. Dotyczy to choćby tematu związanego z obecnym stanem i perspektywami globalizacji oraz jej skutkami. Wciąż warto analizować i oceniać założenia, ewentualne konsekwencje i pożytki płynące z Nowej Ekonomii Strukturalnej oraz możliwości wykorzystania jej przez państwa chcące szybciej dogonić kraje najwyżej rozwinięte. W prezentowanej pracy przedstawione są również poglądy poruszające temat szans i impulsów rozwojowych dla Polski. Co ważne, oprócz środowisk naukowych, publikacja zgodnie z zamierzeniem powinna dotrzeć także do szerszej grupy Czytelników, w tym decydentów gospodarczych i politycznych oraz przedsiębiorców i środowisk opiniotwórczych. 
C Z ĘŚĆ I 



\section{ALOJZY Z. NOWAK}

\section{Jaka przyszłość globalnej gospodarki?}

Artykuł podejmuje kwestie związane z obecnym etapem globalizacji. Analizuje główne przyczyny ekonomicznej i społecznej kontrrewolucji antyliberalnej oraz podkreśla jej wpływ na nowo rodzący się kształt światowego ładu gospodarczego. Finansyzacja gospodarki światowej, będąca w dużej mierze rezultatem niekontrolowanych dostatecznie rynków finansowych, jak i bardzo dotkliwe dla społeczeństw bańki spekulacyjne, przyczynity się m.in. do zakwestionowania modelu rozwojowego opartego głównie na rynkach, bez należytego wsparcia regulacyjnego i kontrolnego ze strony państwa. Skoro istnieje coraz powszechniejsze przekonanie, że na obecnym etapie rozwoju gospodarczego globalizacja oparta na neoliberalnych zasadach powinna być gruntownie przemyślana, to w jakim kierunku powinny nastąpić korekty lub zmiany obecnego stanu. Autor podziela punkt widzenia Josepha E Stiglitza, że Unia Europejska jest taką organizacją, która może i powinna w większym stopniu stanowić punkt odniesienia dla integracji gospodarczej i społecznej, a przez to i dla nowo kształtującego się globalnego ładu ekonomicznego. Zwiększenie integracji politycznej, regulacyjnej i stymulacyjnej roli państwa w gospodarce nie oznacza zastępowania rynkowej konkurencyjności, poprzez politykę protekcjonizmu i nacjonalizmu ekonomicznego.

Słowa kluczowe: globalizacja, kontrrewolucja antyliberalna, paradygmat rozwojowy, Unia Europejska, Nowa Ekonomia Strukturalna.

\section{Wprowadzenie}

Interwencja na szeroką skalę ostatecznych pożyczkodawców (rządów i banków centralnych) zakończyła eskalację utraty płynności finansowej przez zdecydowaną większość podstawowych światowych podmiotów gospodarczych i finansowych (banki komercyjne, fundusze inwestycyjne, fundusze ubezpieczeniowe etc.). Spowodowało to wzrost optymizmu w gospodarce globalnej. Według najnowszych prognoz Organizacji Współpracy Gospodarczej i Rozwoju (OECD), gospodarka światowa wzrośnie w roku 2018, a także w 2019 r. o 3,9 procent, czyli najwięcej od 2011 roku. Przyspieszenie tempa nastąpi głównie za sprawą ożywienia w handlu i w inwestycjach ${ }^{1}$. Charakterystyczna wydaje się jednak opi-

1 https://www.ppr.pl/wiadomosci/oecd-gospodarka-swiatowa-w-2018-i-2019-r 
nia jednej z najbardziej prestiżowych brytyjskich gazet ekonomicznych, która prognozuje, że „globalizacja przetrwała wiele rzeczy, ale inwazja merkantylistycznego populizmu może być dla niej wyzwaniem największym od dziesięcioleci. Rok 2018 nie jest bynajmniej dla międzynarodowego handlu katastrofalny, ale może się okazać rokiem trwożnego wyczekiwania na wybuch wojen handlowych" (Financial Times, 2018).

Istnieje poważna obawa, że coraz więcej rządów, dostrzegając słabości obecnego etapu globalizacji, może przesadnie chronić przed zagraniczną konkurencją swoje gospodarki, w nadziei, że przyniesie to dobre rezultaty ekonomiczne i społeczne.

Coraz częściej stawiane jest również pytanie o rolę państwa i rynku w procesach gospodarczych. Poprzedni światowy kryzys finansowy postawił w centrum uwagi m.in. kwestię kontroli międzynarodowych przepływów kapitału. Teraz, w szczególności, w odniesieniu do gospodarek wschodzących pojawia się kwestia zasadności wprowadzenia określonych narzędzi kontroli transferu kapitału (Wojtyna, 2017), lecz temat ten zasługuje na oddzielne potraktowanie.

\section{Przyczyny ekonomiczne i społeczne kontrrewolucji antyliberalnej}

Jeden z najpoważniejszych ośrodków analitycznych na świecie - The Economist Intelligence - uważa, że potencjalny problem tkwi także w tym, że obecne i przyszłe działania prezydenta Donalda Trumpa wpisują się w obecny trend w światowej gospodarce. A mianowicie, coraz więcej krajów otwarcie mówi o tym, by zamykać swoje gospodarki przed zagraniczną konkurencją lub przynajmniej bardziej koncentrować się na wykorzystaniu własnych zasobów.

Jednakże problem jest znacznie poważniejszy i głębszy. W książce pt. Nowy Pragmatyzm kontra Nowy Nacjonalizm Grzegorz W. Kołodko trafnie zauważa, że występujące obecnie na świecie zjawiska i procesy społeczno-gospodarcze są coraz bardziej skomplikowane i konfliktogenne (Kołodko i Koźmiński, 2017). Gotów on jest przypisać je w dużej mierze nierównowadze zarówno społecznej, jak i gospodarczej, ale również procesom demograficznym oraz zagrożeniom naturalnego środowiska człowieka. Jego zdaniem, zjawiska te nie są jeszcze dostatecznie objaśnione przez nauki ekonomiczne, ponieważ - jak twierdzi - dotychczasowe szkoły ekonomii, a zwłaszcza ekonomii głównego nurtu, okazują się przestarzałe, nieadekwatne dla nowych problemów i w tym zakresie należy poszukać czegoś nowego (Kołodko i Koźmiński, 2017, s. 11). 
Andrzej K. Koźmiński uważa z kolei, że „ludzie na całym świecie zaczynają aspirować do coraz wyższego poziomu dobrobytu, i jak dawniej, w minionych wiekach, pokornie godzili się ze swoim losem, tak w chwili obecnej takiej zgody już nie ma i występuje potencjał gwałtowanego protestu" (Kołodko i Koźmiński, 2017, s. 11).

Pogląd ten koresponduje $\mathrm{z}$ głównymi konkluzjami badań Thomasa Piketty'ego, który w swojej książce pt. Kapitat w XXI wieku stwierdza, iż „dynamika akumulacji kapitału prywatnego prowadzi nieuchronnie do coraz większej koncentracji bogactw i władzy w kilku rękach...” (Piketty, 2015, s. 11). Piketty konkluduje: „Kiedy wskaźnik rentowności kapitału przewyższa w sposób trwały stopę wzrostu produkcji i dochodu, jak działo się to do XIX wieku i może stać się normą w wieku XXI, kapitalizm automatycznie tworzy arbitralne nierówności nie do zniesienia, stawiając pod znakiem zapytania podstawowe wartości, na jakich opierają się nasze demokratyczne społeczeństwa" (Piketty, 2015, s. 11). Wątpi on, iżby „równoważące się siły wzrostu, konkurencji i postępu technicznego prowadziły spontanicznie do redukcji nierówności i harmonijnej stabilizacji w zaawansowanych fazach rozwoju, jak myślał Kuznets w XX wieku” (Piketty, 2015, s. 11). W swoich badaniach Piketty słusznie zagłębia się w historię, chce bowiem wykazać tezę, że amerykańskie marzenie, czyli obietnica egalitarnego kapitalizmu w stylu zachodnim, nie jest w stanie się spełnić i prawdopodobnie w przyszłości nic się tu nie zmieni. W systemie tym bowiem tempo wzrostu gospodarczego jest zawsze niższe od stopy zysku z zainwestowanego kapitału. Ze wzrostu korzysta całe społeczeństwo, z zysku natomiast - jedynie najbogatsi (Piketty, 2015, s. 373).

Profesor Studiów Europejskich na Uniwersytecie w Oksfordzie, Jan Zielonka, w książce pt. Kontrrewolucja. Liberalna Europa $w$ odwrocie, próbuje dostrzec przyczyny, które stały i stoją u podstaw „kontrrewolucji” antyliberalnej i ustanowienia rządów i partii politycznych kwestionujących liberalną odmianę demokracji oraz reformy rynkowe oparte na konsensusie waszyngtońskim (Zielonka, 2018). „W całej Europie politykę w coraz większym stopniu postrzegano jako sztukę instytucjonalnej inżynierii, nie zaś jako sztukę negocjacji między elitami a elektoratem. Coraz więcej władzy powierzano instytucjom nie wyłanianym w wyborach powszechnych - bankom centralnym, sądom konstytucyjnym, agencjom regulacyjnym - by upewnić się, że podejmowaniem decyzji politycznych będzie rządzić rozum, nie zaś namiętności. Uleganie naciskom społecznym uważano za nieodpowiedzialne, jeśli nie wręcz niebezpieczne... Mówiono, że obywateli należy raczej edukować niż słuchać” (Zielonka, 2018, s. 24). 
Choć to zaskakująca diagnoza Profesora o poglądach liberalnych, który, mimo wspominanej wyżej krytyki, wierzy jednak w odrodzenie nowego liberalizmu, zasługuje na przytoczenie. Mamy bowiem do czynienia, przynajmniej na kontynencie europejskim i w Stanach Zjednoczonych, z wyraźnie zauważalnymi tendencjami, które przekładają się jednocześnie na charakter i architekturę nowego ładu ekonomicznego i społecznego.

Dani Rodrick już wcześniej twierdził, że istnieje konflikt między demokracją, nieograniczoną globalizacją gospodarczą i autonomią bądź suwerennością państw. Dowodzit, że niemożliwa jest koegzystencja tych trzech celów polityki na poziomie państwa narodowego.

Brytyjski tygodnik „The Economist” (2018) w analizie pn. Dlaczego demokracja umiera przypomniał, że w 1941 roku na świecie było tylko kilka demokracji. $\mathrm{Za}$ to do 2000 roku tylko w 8 krajach nie przeprowadzono wolnych wyborów. W badaniach dokonanych w 38 krajach, 4 na 5 osób preferowało wtedy system demokratyczny. Wtedy to właśnie, w 1989 roku, Francis Fukuyama wieszczył „koniec historii” - demokracja zwycięży - system liberalnej demokracji będzie powszechny, a gospodarka rynkowa niezagrożona (Fukuyama, 2009).

Dziś, jak pisze tygodnik „The Economist”, mamy do czynienia z odwrotem od demokracji. Pismo próbuje przytoczyć potwierdzające to przykłady i je zracjonalizować. Proces tego odwrotu wyraźnie przyspieszył w czasie kryzysu finansowego w latach 2007-2009, a wraz z postępującą destabilizacją spowodowaną migracją i nasileniem konfliktów zbrojnych:

1) narosły odczucia społeczne, że elity demokratyczne nie potrafią sobie poradzić w pełni lub całkowicie z pokonaniem kryzysu oraz napięciami na tle politycznym i społecznym. Największy kryzys finansowy od czasu depresji lat trzydziestych, narastający kryzys zadłużenia w Europie, biliony publicznych pieniędzy przekazane na ratowanie banków, pogłębiające się nierówności majątkowe, to wszystko przeraziło i sfrustrowało miliony osób;

2) nie pojawiło się wielu nowych silnych przywódców o demokratycznych przekonaniach w rodzaju Konrada Adenauera, Margaret Thatcher czy ojców założycieli Unii Europejskiej. Pojawili się za to silni przywódcy (strongmeni), którzy podważyli zaufanie do demokracji liberalnej i dotychczasowych elit.

Nowi silni przywódcy (strongmeni) zaproponowali natomiast:

- rozmontowanie lub ograniczenie dotychczasowych instytucji i obyczajów demokratycznych;

- wykreowanie i poszukiwanie wroga (Donald Trump za głównego wroga uznał elity demokratyczne i liberalne). W zamian nastąpiło poszukiwanie nowych elit, ale takich, które są lojalne, posiadają kwalifikacje, które nie kwestionują 
autorytetu przywódcy (także od strony intelektualnej). Elity islamskie z kolei przestraszyły się rosnącej roli nowych elit świeckich - nieudany, co prawda, zamach w Turcji był jednak dla nich sygnałem zagrożenia ich pozycji;

- nową politykę gospodarczą, która odwołuje się do pojęcia suwerenności gospodarczej i inaczej definiowanego interesu narodowego w warunkach procesów globalizacji.

\section{Znaki zapytania w sprawie międzynarodowego ładu}

Wszystkie powyższe rozważania prowadzą także do postawienia znaków zapytania związanych $\mathrm{z}$ dotychczasowym ładem w skali światowej, a szczególnie $z$ ładem gospodarczym. Do niedawna paradygmat rozwojowy oparty był na wspomnianym konsensusie waszyngtońskim. Wyrastał on nie tylko z naukowych badań, lecz także realnych tendencji, występujących w procesie globalizacji. Megatrendy w gospodarce światowej to przede wszystkim: deregulacja, liberalizacja, prywatyzacja i integracja. Te cztery główne tendencje, występujące w gospodarce światowej, stały się zasadniczym kanonem polityki ekonomicznej wielu państw.

Podstawowe wytyczne konsensusu dla polityki gospodarczej ulegały z czasem pewnym modyfikacjom, jednak ich główny trzon nie podlegał zmianom. W globalnej gospodarce stały się swego rodzaju wzorcem rozwojowym dla bardzo wielu państw o różnym stopniu zaawansowania ekonomicznego i społecznego. Momentem przełomowym weryfikującym ustalenia konsensusu stał się niespodziewany, co do skali i rozmiarów, światowy kryzys finansowy w latach 2007-2009. Pewne założenia teoretyczne teorii ekonomicznych opartych na wierze w samoczynne mechanizmy naprawcze wolnego rynku nie sprawdziły się. Co więcej, system, pozbawiony mechanizmów regulacji zaczął „produkować” różnego rodzaju wynaturzenia. Szczególnie dotkliwe dla gospodarki, ale i zwykłych obywateli okazały się „błędy i wypaczenia”, które pojawiły się na rynkach finansowych (Nowak, 2013). Narastały także problemy natury społecznej i politycznej, o których wcześniej napisano w tej rozprawie. Konsensus waszyngtonski, wyrosły z neoliberalnych teorii, został poważnie zakwestionowany.

Niemniej jednak jednoznacznie negatywne oceny skutków jego implementacji są także nieuprawnione. Można znaleźć też przykłady państw, które, realizując wspomniane założenia, doświadczyły internacjonalizacji swojej produkcji i dystrybucji, transferu i importu nowoczesnych technologii, rewolucji informatycznej, rozwoju nowych rynków etc. Polityka gospodarcza, oparta na konsensusie stała się istotnym elementem transformacji systemowej w wielu krajach tzw. gospodarek wschodzących, w tym i Polski. 
Jednak bezkrytyczna wiara w samoczynne mechanizmy naprawcze „wolnego rynku" nie sprawdziła się, co, jak wspomniano, ukazał w szczególności światowy kryzys finansowy (2007-2009), którego skutki - jak się wydaje - nie zostały ostatecznie i trwale przezwyciężone. Finansyzacja gospodarki światowej, będąca w dużej mierze rezultatem niekontrolowanych dostatecznie rynków finansowych, czy bardzo dotkliwe dla społeczeństw bańki spekulacyjne przyczyniły się m.in. do zakwestionowania modelu rozwojowego opartego głównie na rynkach, bez należytego wsparcia regulacyjnego i kontrolnego ze strony państwa. Do krytyki modelu, którego podstawą są zasady neoliberalne dołączyć można wszystkie inne ich konsekwencje: frustracje i nierówności społeczne, polityczne, ekologiczne zagrożenia, o których napisano wcześniej.

\section{Charakterystyka nowych tendencji globalizacyjnych}

Rozważania należy poprzedzić ogólną charakterystyką nowych tendencji w gospodarkach najważniejszych krajów świata oraz konsekwencji nowych zjawisk w procesie globalizacji.

- Coraz szybciej postępuje rewolucja technologiczna. Zbieranie i przechowywanie ogromnych ilości informacji do celów analitycznych w różnych dziedzinach praktykowane było od dawna. Dziś jednak gwałtowny wzrost i dostępność danych (big data), a jednocześnie ich zaprogramowana selekcja prowadzą do uzyskania jakościowo nowych możliwości. Łączenie i zestawianie relacji, hierarchii i różnorodnych powiązań, zbieranie i selekcjonowanie danych z różnych źródeł, w szczególności w sferze gospodarczej, otwiera nowe możliwości podejmowania szybkich i bardziej wiarygodnych decyzji oraz zmian w strategiach biznesowych. Z tej postępującej technologicznej rewolucji korzystają $\mathrm{w}$ pierwszej kolejności wielkie korporacje transnarodowe. One najszybciej dysponują zasobami umożliwiającymi dopasowywanie, oczyszczanie i przekształcanie danych w różnych systemach, również po to, aby uzyskać przewagę konkurencyjną na globalnym rynku.

- W wielu krajach (np. Chiny, Indie, Izrael) obserwujemy szybkie przechodzenie od rozwoju imitacyjnego do rozwoju opartego na innowacjach. Prowadzi to do coraz większych sporów, a nawet konfliktów, np. w kwestii przestrzegania praw autorskich.

- Kryzys finansowy lat 2007-2009 zmienił na trwałe dynamikę rozwojową tradycyjnych i nowo rodzących się potęg gospodarczych. Kontynent azjatycki staje się jednym z najważniejszych centrów gospodarki światowej. A co także 
bardzo ważne - pojawianie się nowych potęg gospodarczych wcale nie opiera się wyłącznie na zasadach neoliberalnych. Nawet Międzynarodowy Fundusz Walutowy zakwestionował główne założenia konsensusu waszyngtońskiego.

- Coraz bardziej bezwzględna rywalizacja na globalnym rynku odbywa się w sytuacji, gdy pokłady naturalnych zasobów na ziemi są na wyczerpaniu. Ale pojawiają się również opinie, że jeszcze groźniejszy na dłuższą metę jest brak wspólnej troski o ochronę środowiska naturalnego i spory wokół polityki klimatycznej.

- Pogłębia się podział na beneficjentów i outsiderów współczesnej globalizacji. Jak wspomniano wcześniej, rosną nierówności, stawiając pod znakiem zapytania podstawowe wartości, na jakich opierają się współczesne społeczeństwa. Wywołuje to bunt i narastanie sprzeciwu wobec praktyk globalizmu i jego bezkrytycznych obrońców.

- Wszystkie wymienione wcześniej zjawiska w różnym stopniu sprzyjają pojawieniu się nacjonalizmów gospodarczych i przekonaniu, iż w obliczu słabości i ułomności dotychczasowych tendencji występujących na globalnych rynkach należy wprowadzić jakieś formy protekcjonizmu, ograniczeń w wolnym handlu, nawet jeśli potencjalnie grozić to będzie wybuchem konfliktów handlowych. Takie podejście wzmacnia też rolę, wydawało się już nieco mniej eksponowanego znaczenia, soft i hard power poszczególnych państw.

Ów „,nowy nacjonalizm”, jak nazywają go autorzy książki (Kołodko i Koźmiński, 2017, s. 7) - „Nowy pragmatyzm, czy nowy nacjonalizm” charakteryzuje się w obecnych warunkach również „odrodzeniem agresywnych postaw, poglądów i polityki, która wydawało się, wygasła już raz na zawsze po straszliwych doświadczeniach dwóch wojen światowych". Tak więc w globalnej rywalizacji o charakterze gospodarczym wraca znaczenie polityki zagranicznej, która zakłada połączenie soft i hard power (m.in. czynników politycznych i manipulacyjnych) jako istotnych elementów skutecznie chroniących i wzmacniających interes narodowy.

\section{Globalizacja, ale jaka?}

Skoro istnieje coraz powszechniejsze przekonanie, że na obecnym etapie rozwoju gospodarczego globalizacja oparta na neoliberalnych zasadach powinna być gruntowanie przemyślana, to w jakim kierunku powinny nastąpić korekty lub zmiany obecnego stanu? Czy istnieje realistyczna koncepcja, aby skorzystać z nieodwracalności procesu globalizacji z jego także pozytywnymi rezultatami, 
ale dla coraz większej ilości państw świata. A jednocześnie, jak trzeba zminimalizować ewidentne słabości i wynaturzenia, skutkujące narastającą groźną degradacją społeczną i buntem wielu społeczeństw?

Ktoś, kto tylko w jednej dziedzinie skutecznie zaprojektuje i zapanuje nad żywiołem i siłą współczesnych rynków, w tym przede wszystkim rynków finansowych, a przez to zmieni w istotny sposób procesy i wektory globalizacji, zasłuży na Nagrodę Nobla.

Warto jednak przynajmniej nie popełniać nowych błędów lub nie warto wspierać tych scenariuszy zmian, które mogą potencjalnie tworzyć nowe zagrożenia, a może i nowe, poważne konflikty. Próby rozwiązywania sprzeczności naturalnych interesów koncernów czy państw poprzez formy indywidualnego protekcjonizmu, politykę nakładania ceł, zastępowanie rynkowej konkurencyjności, prowadzenie agresywnych strategii politycznych, zastępujących mechanizmy ponadnarodowych negocjacji i uzgodnień, doprowadzą najpewniej jedynie do powrotu egoizmów narodowych.

Tymczasem w globalnej gospodarce, gdzie istnieje także obiektywna rywalizacja i walka o interesy narodowe, państwa narodowe skazane są raczej na porażki, ponieważ poprzez realne niebezpieczeństwo izolacjonizmu lub separacji państwa te mają znacznie mniejsze możliwości realizacji swoich interesów. Dotyczy to nawet tak potężnych i wiodących krajów, jak Stany Zjednoczone. Choć do niedawna wydawało się to niemożliwe.

Zwiększenie regulacyjnej i stymulacyjnej roli państwa w gospodarce - jako konieczny postulat ograniczenia niekorzystnych procesów zachodzących na globalnym rynku - nie oznacza wyboru na rzecz ograniczania integracji i światowego handlu czy próby zastępowania rynkowej konkurencyjności poprzez politykę protekcjonizmu i nacjonalizmu ekonomicznego. Przy wszystkich mankamentach, integracja i swobodny przepływ technologii, kapitału i siły roboczej to jedne z najsilniejszych impulsów rozwojowych w skali państw, regionów i świata. „Zbiurokratyzowane wszechmogące państwo jest tak samo nie do przyjęcia, jak całkowity wolny rynek" (Nowak i Ryć, 2017, s. 81).

\section{Gdzie szukać dodatkowych impulsów rozwojowych?}

Skoro próba zastąpienia dotychczasowego ładu na drodze różnych form hegemonii jego głównych aktorów, a nie poprzez próby konsensusu, zostałaby zrealizowana, to globalna gospodarka będzie stawała się jeszcze poważniejszym zarzewiem globalnych konfliktów. Procesy globalizacji należy zatem poddać 
większej kontroli ze strony organizacji ponadnarodowych lub za pośrednictwem regulacji prawnych i innych, które zostaną uzgodnione poprzez konsensus lub przynajmniej poprzez większość państw. Będzie to wszakże niesłychanie trudne do zrealizowania. Realistycznie oceniając, nadzieja, iż jest możliwy na szczeblu globalnym „nowy pragmatyzm” ze strony głównych aktorów światowej gospodarki, wydaje się być płonna. Warto więc poszukać rozwiązań sprawdzonych w ujęciu nie tyle globalnym, ile regionalnym.

\subsection{Spójrzmy na Unię Europejską}

Unia Europejska jest taką organizacją, która może i powinna w większym stopniu stanowić punkt odniesienia dla integracji gospodarczej i społecznej, a przez to szerzej - dla globalnego ładu.

Laureat Nagrody Nobla, Joseph E. Stiglitz, w książce pt. Euro. W jaki sposób wspólna waluta zagraża przyszłości Europy (2017), który przekonująco ukazuje, jak dotychczasowe rozwiązania, szczególnie w strefie euro, przyczyniają się raczej do tworzenia rozbieżności niż spójności w europejskiej wspólnocie, zadaje pytanie, czy Europa może rozwijać się bez euro? W odróżnieniu od większości ekonomistów amerykańskich, Stiglitz pozytywnie rozważa, jak stworzyć strefę euro, która będzie działać. Podkreśla on swoją nadzieję, że to co proponuje przyczyni się do wdrożenia rozwiązań, które zapewnią kontynentowi dobrobyt i „wesprą naszą solidarność”. Jednak zakłada również, że jeśli przeprowadzenie gruntowanych reform, które proponuje, okaże się niemożliwe do wykonania, „Europa musi zdecydować się na porzucenie euro, aby ocalić projekt o wiele ważniejszy - projekt politycznej integracji, istotny nie tylko dla Starego Kontynentu, lecz także dla całego świata" (Stiglizt, 2017, s. 69).

Joseph Stiglitz jest przekonany, że jeśli wspólna waluta ma działać, to „potrzeba nam więcej Europy”. Precyzuje przy tym, że nie chodzi mu od razu o federację na kształt Stanów Zjednoczonych, gdzie dwie trzecie wszystkich wydatków publicznych ma miejsce na poziomie centralnym, ale o zdecydowane podniesienie obecnego stopnia integracji. Bardziej sprawny Jednolity Rynek i swobodna migracja wymagają „więcej Europy”. Tym bardziej więc wspólna waluta wymaga „więcej Europy” (Stiglizt, 2017, s. 69). Zaproponowane przez niego plany reform i gruntowanych zmian, które w konsekwencji mają prowadzić do uratowania strefy euro i projektu europejskiego zasługują na oddzielne potraktowanie, ponieważ kraje strefy euro bez dalszych reform, ale i bez akceptacji dla nich nadal będą narażone na pogłębienie dywergencji i konflikty.

J. Stiglitz spogląda jednak na Unię Europejską i strefę euro szerzej - w kontekście globalizacji. Pisze on, że „wciąż toczy się debata; jakie są warunki uda- 
nej globalizacji. Co robić, jeśli wcale nie przebiega ona tak, jak byśmy sobie tego życzyli? Jakie niesie za sobą koszta i kto na niej zyskuje? Kto przegrywa? W tym sensie sukcesy i porażki Europy są dobrą lekcją na przyszłość - zarówno, jak chodzi o integrację regionalną, jak i tę naukę na poziomie światowym...". Stiglitz na przykładzie Unii Europejskiej podkreśla, że „integracja gospodarcza (globalizacja) nie powiedzie się, jeśli pozostawi w tyle integrację polityczną. Rośnie więc potrzeba działań kolektywnych - tak by mieć pewność, że wzajemne korzyści będą większe od wyrządzanych sobie nawzajem szkód" (Stiglizt, 2017, s. 69). Przy wszystkich zastrzeżeniach odnośnie do obecnego etapu funkcjonowania Unii Europejskiej i strefy euro, Joseph E. Stiglitz, traktuje Unię Europejską jako istotny projekt, ważny nie tylko dla Starego Kontynentu. Jak podkreśla „powodzenie projektu europejskiego leży nie tylko w interesie Europy”.

Europejską regionalizację można postrzegać jako istotny element globalizacji. Jednak wychodzenie Wielkiej Brytanii z UE oraz nie do końca przezwyciężone skutki kryzysu finansowego lat 2007-2009 czy mankamenty strefy euro stawiają jednak pewne znaki zapytania nad podążaniem za europejskim modelem rozwojowym. Tym bardziej, że pojawiły się nowe azjatyckie potęgi gospodarcze, które uczyniły kontynent azjatycki jednym z najważniejszych centrów gospodarki światowej i tym samym zmieniają wektory globalizacji.

\section{Globalizacja z polskiej perspektywy}

Korzyści płynące z integracji gospodarki polskiej z gospodarką światową w ramach Światowej Organizacji Handlu (WTO) oraz Unii Europejskiej i uczestnictwo w procesie globalizacji pociągnęły za sobą także pewne zjawiska ujemne, które należy traktować jako koszty. Jednak w ogólnym bilansie korzyści przeważają nad kosztami.

Jako kraj doganiający państwa najbardziej rozwinięte, Polska dokonuje także rewizji powszechnie uznawanych teorii ekonomicznych. W większym stopniu przygląda się i wyciąga praktyczne wnioski z doświadczeń tych krajów, które osiągnęły sukces gospodarczy, nie podążając klasyczną drogą neoliberalizmu. Natomiast zwraca zdecydowanie większą uwagę na rozwój gospodarczy jako proces przemian strukturalnych i politykę przemysłową, która jest ważnym narzędziem pozwalającym wytyczać priorytety w zakresie wykorzystania ograniczonych zasobów. Stąd też zainteresowanie polskich władz doktryną Nowej Polityki Strukturalnej, której jednym z najważniejszych autorów jest chiński ekonomista Justin Yifu Lin. Istota tej doktryny polega na tym, iż czynnikiem 
o znaczeniu decydującym dla sukcesu rozwojowego jest państwo, które umożliwia ten rozwój, prowadząc odpowiednią politykę przemysłową. Jak wskazuje Justin Y. Lin, rozwój gospodarczy jest procesem przemian strukturalnych. Pożądana polityka przemysłowa powinna mieć zatem na celu ułatwianie rozwoju branż posiadających ukryte przewagi konkurencyjne, ale również powinna pomóc firmom w wychodzeniu z tych branż, w których dany kraj traci przewagi komparatywne. Na konkurencyjnym rynku rządy winny wynagradzać przedsiębiorstwa za wnoszenie wartości dodanych do domeny publicznej, wypracowanych przez pierwszych inicjatorów w nowych branżach - tych, w których kraj posiada ukryte przewagi komparatywne - ale także zapewniać i koordynować wspieranie twardej i miękkiej infrastruktury, aby obniżać koszty transakcyjne (Lin, 2017, s. 199-200).

Polska w pewnych segmentach polityki gospodarczej korzysta obecnie ze wskazań Nowej Ekonomii Strukturalnej, szczególnie poprzez bardziej aktywną rolę państwa, usuwanie barier inwestycyjnych w celu nadrobienia opóźnienia technologicznego w wielu ważnych sektorach gospodarki. Polska w warunkach globalnej gospodarki chce więc uwolnić i uruchomić istniejący potencjał wzrostu, a przez to osiągnąć sukces rozwojowy. Szuka więc w praktyce rozwiązań, które pozwolą jej jak najkorzystniej zaistnieć w zmieniających się realiach gospodarki światowej.

\section{Bibliografia}

De Grauwe, P. i Ji, Y. (2018). Inżynieria finansowa nie ustabilizuje niestabilnej strefy euro. Obserwator Finansowy, 19 kwietnia.

Financial Times. (2018). Komentarz redakcyjny, 28.06.2018.

Fukuyama, F. (2009). Koniec historii. Kraków: Wydawnictwo Znak.

http://globaleconomy.pl

https://www.ppr.pl/wiadomosci/oecd-gospodarka-swiatowa-w-2018-i-2019-r

Kołodko, G.W. i Koźmiński, A.K. (2017). Nowy Pragmatyzm Kontra Nowy Nacjonalizm. Warszawa: Wydawnictwo Prószyński i S-ka.

Krugman, P. (2008). The Return of Depression Economics and the Crisis of 2008. December. USA: W.W. Norton\&Company Inc.

Lin, J.Y. (2017). Nowa Ekonomia Strukturalna dla gospodarek doganiających. W: J.Y. Lin, A.Z. Nowak (red), Nowa Ekonomia Strukturalna wobec krajów mniej zaawansowanych. Warszawskiego: Wydawnictwo Naukowe Wydziału Zarządzania Uniwersytetu Warszawskiego.

Nowak, A.Z. (2013). Współczesny świat w erze turbulencji. W: J. Bogdanienko, W. Piotrowski (red.), Zarzadzanie: tradycja i nowoczesność. Warszawa: PWE.

Nowak, A.Z., Wojtaszczyk, K.A. i Zamęcki, Ł. (2016). Poland in the European Union. Coleccion Universidad 8. Madrid: Schedas. 
Nowak, A.Z. i Ryć, K. (2017). Polityka w regionach $w$ warunkach globalizacji. Warszawa: Wydawnictwo Naukowe Wydziału Zarządzania Uniwersytetu Warszawskiego.

Nowak, A.Z. i Lin, J.Y. (2017). New Structural Economics for Less Advanced Countries. Warszawa: Wydawnictwo Naukowe Wydziału Zarządzania Uniwersytetu Warszawskiego. Nowak, A.Z. i Taplin, R. (2010). Intelectual Property, Innovation and Management in Emerging Economics. London: Routledge.

Piketty, Th. (2015). Kapitat w XXI wieku. Warszawa: Wydawnictwo Krytyki Politycznej.

Stiglitz, J.E. (2006). Making Globalization Work. USA: W.W. Norton\&Company Inc., September.

Stiglitz, J.E. (2008) The Triumphant Return of John Maynard Keynes. Guatemala Times, 5 December.

Stiglizt, J.E. (2017). Euro. W jaki sposób wspólna waluta zagraża przyszłości Europy. Warszawa: Wydawnictwo Krytyka Polityczna.

The Economist. (2018). Why the democracy dies, 16 June, No. 12.

Wojtyna, A. (2017). Nowa faza dyskusji o kontroli międzynarodowych przepływów kapitału. Gospodarka Narodowa, listopad - grudzień.

Wojtyna, A. (2008). Współczesna ekonomia - kontynuacja, czy poszukiwanie paradygmatu. Ekonomista, 1.

Zielonka, J. (2018). Kontrrewolucja. Liberalna Europa w odwrocie. Warszawa: PWN. 


\section{Wolny handel czy niepohamowana promocja interesów narodowych i korporacyjnych?}

W zakresie oceny roli wolnego handlu w zglobalizowanym świecie mamy do czynienia z rozziewem pomiędzy teorią i praktyką. Teza ta dotyczy w szczególności neoklasycznej interpretacji wolnego handlu i jej faktycznego znaczenia w praktyce. Przeprowadzona tu analiza wskazuje na konieczność zachowania umiaru. Z jednej strony, nie jest właściwe aprobowanie handlu wolnego bez ograniczeń, typowe dla podejścia laissez faire. Z drugiej zaś - nie da się również obronić postaw autarchii ani agresywnej, merkantylistycznej promocji własnych interesów narodowych lub korporacyjnych. Ponadto, w relacjach tych ważną rolę odgrywają aktywa niematerialne, takie jak prawa własności intelektualnej i ocena ich wartości w kontekście globalizacji. Aktywa takie są źródłem zarówno efektów korzystnych, jak i konsekwencji w samych Stanach Zjednoczonych i na całym świecie. Jeżeli nie zostanie zachowana równowaga pomiędzy poszczególnymi czynnikami tego równania, przegranymi będą wszyscy: masy pracujące, rządy, ustrój demokratyczny, środowisko naturalne i ogół konsumentów.

Słowa kluczowe: wolny handel, globalizacja, prawa własności intelektualnej, wycena.

\section{Wprowadzenie}

Wśród dziedzin ekonomii, w których teoria i praktyka najjaskrawiej przeczą sobie nawzajem, kwestia wolnego handlu wysuwa się na jedno z pierwszych miejsc.

W teorii wolny handel powinien - a wręcz musi - przynosić korzyści wszystkim zaangażowanym weń stronom. Uzasadnienie tej tezy jest chyba oczywiste, intuicyjnie wyczuwalne nawet dla zupełnie przypadkowego obserwatora zjawisk ekonomicznych. Jedną z tych ewidentnych racji jest wolność działania. Gdyby dla danego uczestnika handel nie był korzystny, ten po prostu nie angażowałby się w jego mechanizm.

Inne rozumowanie w tym kontekście wywodzi się z pojęcia „przewagi komparatywnej", wprowadzonego przez Davida Ricardo. Jeżeli dana strona produkuje to, co jest w stanie wyprodukować i czyni to ze względną wydajnością, a oprócz tego zaopatruje się na rynku w inne towary i usługi, to łączna produk- 
cja dzięki temu wzrasta i wszyscy uczestnicy powinni czerpać z tego korzyści. Co więcej, taki handel sprzyja kształceniu specjalizacji, która powinna podnosić wydajność. Słowem, wolny rynek stanowi napęd dla efektywności Pareto. Prowadzi do takich dystrybucji ekonomicznych, w których nie jest możliwe, by ktokolwiek odniósł korzyści bez poniesienia przez kogoś innego straty.

W praktyce, pobocze szlaku wiodącego ku powszechnym korzyściom usiane jest niepowodzeniami. Kraje, które rygorystycznie przestrzegały reguł wolnego rynku, wolnego handlu i konsensusu waszyngtońskiego rozwijały się wolniej bądź nie rozwijały się wcale. I na odwrót, kraje, które dokonały cudów gospodarczych, w tym Stany Zjednoczone w wiekach dziewiętnastym i dwudziestym, wcześniej odrzuciły wolność handlu na korzyść wprowadzenia w pewnym zakresie dyryżyzmu, włącznie z wysokimi cłami i objęciem pomocą państwa sektorów tworzących wartość dodaną.

Wszyscy, którzy na tym zyskali uznawali przewagę komparatywną nie za z góry stałą daną, lecz za dynamiczną zmienną i systematycznie generowali swoje własne przewagi komparatywne. Nawet w Stanach Zjednoczonych pod wpływem myśli Alexandra Hamiltona państwo nałożyło wysokie cła, inwestowało w bank, w budowę kanałów oraz w produkcję przemysłową, a także odmawiało wypłacania honorariów od własności intelektualnej (Cohen i DeLong, 2016). W naszych czasach odmowa wypłacenia wynagrodzenia za prawa własności intelektualnej wywołałaby powszechne oburzenie.

W rzeczywistości prawa własności intelektualnej oraz wycena faktycznej wartości aktywów niematerialnych odgrywają kluczową rolę wśród przyczyn wszczęcia przez Stany Zjednoczone pod prezydenturą Donalda Trumpa wojny handlowej i nałożenia przez ten kraj wyższych stawek celnych na zarówno gospodarczych sojuszników, jak i konkurentów. Amerykańskie prawa własności intelektualnej są wysoko cenione przez kraje, które nie posiadają odpowiedniej wiedzy albo funduszy, by samodzielnie stworzyć technologie militarne lub biznesowe pozwalające im skutecznie działać w warunkach konkurencji na arenie globalnej. Przestępcy, najczęściej z Iranu, Korei Północnej, Rosji i Chin nieustannie usiłują wykraść zaawansowane amerykańskie technologie i sprzedać je krajom wrogim. Dotyczy to również planów i kopii patentów, które można wykorzystać do budowy broni i do działalności szpiegowskiej.

By posłużyć się niedawnym przykładem, Peter A. Zuccarelli, biznesmen z Teksasu, pracując dla grupy przestępczej kierowanej przez obywatela Stanów Zjednoczonych urodzonego w Pakistanie, przyjął kwotę 1,5 mln dolarów amerykańskich na zakup specjalnych, odpornych na promieniowanie obwodów scalonych na potrzeby programów kosmicznych realizowanych w Chinach i w Rosji. Dokumenty przedstawione w sądzie dowodziły, że Zuccarelli posłużył 
się sfałszowanymi listami przewozowymi, a przemycane części fałszywie oznakował jako komputery z ekranami dotykowymi. W styczniu 2018 roku biznesmen został skazany na karę czterech lat więzienia.

Ta tendencja do wykradania praw własności intelektualnej związanych z technologiami wojskowymi przez wrogów Stanów Zjednoczonych stale rośnie i osiąga rozmiary znacznie przekraczające skalę znaną z epoki Zimnej Wojny (Nixon, 2018).

W środowisku amerykańskiej polityki Chiny są często postrzegane jako kraj, który praktykuje nowatorski i niebezpieczny merkantylizm, polegający na wykradaniu amerykańskich praw własności intelektualnej i tajemnic handlowych w ramach dążenia do dalszego zwiększania swojej globalnej dominacji ekonomicznej i politycznej. Chiny przystąpiły do Światowej Organizacji Handlu w roku 2001 i od tej chwili łamią jej zasady, kradnąc prawa własności intelektualnej wszelkimi dostępnymi metodami - przeważnie poprzez cyberataki (Taplin, 2016).

Dlatego podejmując się oceny kwestii dotyczących wolnego handlu, praw własności intelektualnej i globalizacji, należy zadać sobie pytanie, czy mówimy o handlu wolnym dla wszystkich zaangażowanych stron, czy o handlu pełnym gorliwie promowanych interesów narodowych. Rozumując w ten sposób, dojdziemy, być może, do wniosku, że wykorzystywanie przez różne kraje - zarówno w przeszłości, jak i obecnie - dowolnej polityki handlowej dla własnych korzyści lub narzucanie słabszym krajom polityki wolnego handlu korzystnej dla siebie, w połączeniu z niepowodzeniami praktyk prawdziwie wolnego handlu, prowadzi do odkrycia faktycznych przesłanek i tła teorii wolnego handlu.

\section{Białe plamy w teorii wolnego handlu}

Teoria, utrzymana $\mathrm{w}$ duchu nieinterwencji, dopuszczenia postawy laissez faire, przekonująco i z naciskiem stwierdza, że wszelkie ograniczenia nakładane na handel muszą wywoływać efekt odwrotny od zamierzonego. W praktyce, wszystkie kraje, które odniosły sukces gospodarczy, bezkarnie ignorowały to kategoryczne przykazanie. Jak to możliwe, że praktyka tak radykalnie odbiegała od teorii?

Odpowiedź na to pytanie może obnażyć niejeden martwy punkt w teorii. Jeżeli zaś uświadomimy sobie występowanie na łonie teorii szeregu martwych punktów i białych plam, nie będziemy ulegali złudzeniom, że wolny handel prowadzi do efektywności Pareto lub - tym bardziej - do powszechnej korzyści. 
Jednym z takich martwych punktów jest założenie o autonomii. Przez wieki kraje europejskie handlowały przede wszystkim ze swoimi koloniami. Handel taki odbywał się na zasadach skrajnie nierównych, ponieważ kraje Europy importowały towary i surowce o niskiej wartości dodanej, natomiast eksportowały głównie gotowe produkty o względnie wysokiej wartości dodanej. Handel taki był często wymuszany groźbą użycia siły lub wręcz odbywał się w warunkach przemocy, a miejscowe elity zarządzające koloniami bywały zazwyczaj wyznaczane i utrzymywane na swoich stanowiskach przez mocarstwa europejskie. Handel mógł być korzystny dla owych elit, ale na pewno nie dla ogółu ludności w koloniach.

Wzorzec ten utrzymał się długo i trwał także w okresie, gdy większość kolonii zyskała już niepodległość. Krajom rozwijającym się przedstawiona została doktryna typu „Nie istnieje alternatywa”, a zatem były one zmuszane do zawierania mocno asymetrycznych umów pod milczącą groźbą użycia sankcji ekonomicznych. W tej sytuacji kraje takie rzeczywiście nie miały innego wyjścia niż godzić się na niekorzystne warunki wymiany handlowej.

Innym martwym punktem teorii jest fakt, że przewaga komparatywna może mieć charakter dynamiczny. Kraje, które obecnie opowiadają się za wolnym handlem lub nawet naciskają na jego stosowanie, są to kraje posiadające przewagę komparatywną w sektorach o wysokiej wartości dodanej, nierzadko wysoce kapitałochłonnych. Kraje te jak gdyby zapominają, że swoje przewagi komparatywne zbudowały właśnie poprzez odrzucenie wolnego handlu (choć, z drugiej strony, są doskonale świadome tego, że obecnie dzięki narzuceniu wolnego handlu innym krajom będą mogły łatwiej i dłużej podtrzymać swoją gospodarczą dominację).

Jeżeli przewagi komparatywne mają charakter dynamiczny, to wolny handel nie może prowadzić do osiągnięcia optymalnych dystrybucji Pareto. Kraje budujące nowe przewagi komparatywne kierowałyby konkurencję ku sektorom o większej wartości dodanej, często takim, które wymagają ochrony praw własności intelektualnej. Potencjalne zyski z produktywności w tych sektorach mają tendencję być wyższe, przez co łączna pula bogactwa rośnie bardziej niż miałoby to miejsce w innych warunkach. Historia wydaje się potwierdzać taką tezę 1 .

Jeszcze inną przyczyną suboptymalności Pareto jest krótkoterminowość przepływów kapitałowych. W przeciwieństwie do klasycznego obrazu, ceny środków inwestycyjnych - w tym walut - nie oscylują jedynie wokół stabilnych

1 Szczególnie Amerykanie mogą zadać sobie pytanie, jak wyglądałby PKB ich kraju - a także globalny - gdyby kraj ten pozostał głównie dostawcą surowców rolnych, nie angażując się śmiało w sektory finansów, przemysłu, wysokich technologii oraz tych innowacyjnych pól działalności, które chronione są prawami własności intelektualnej. 
i zrównoważonych poziomów. Inwestorzy nierzadko spekulują, nabywając dane środki dlatego, że aktualnie zyskują one na wartości lub sprzedając je dlatego, że ich wartość akurat spada. Zjawisko to nasila wahania cenowe, prowadząc do powstawania baniek spekulacyjnych i do nagłych załamań. Duże wahania wartości walut zaostrzają nastroje niepewności co do inwestycji długoterminowych, szczególnie w innowacyjnym sektorze działalności badawczo-rozwojowej (R\&D). To z kolei wpływa negatywnie na tempo wzrostu gospodarczego, prowadząc do długookresowych suboptymalnych dystrybucji Pareto.

\section{Wątpliwa efektywność zasady Pareto}

Niezależnie od powyższych rozważań, poważne problemy związane są również z samą kwestią efektywności Pareto. Owszem, społeczność niewolnicza może z powodzeniem osiągać optymalność Pareto, nie jest bowiem możliwe ani uwolnienie niewolniczej siły roboczej, ani należyte wynagradzanie jej właścicieli. Co więcej, istnieją dowody na to, że gospodarka oparta na niewolnictwie może być wydajniejsza od gospodarki opartej na wolnej sile roboczej (Fogel i Engerman, 1974) (i jest to przekonujące, bo trudno zaprzeczyć, że groźba śmierci lub tortur jest skuteczniejszym bodźcem do ciężkiej pracy niż przeciętne wynagrodzenie). Co do zasady, można by redystrybuować produkty zwiększonej w ten sposób wydajności z korzyścią dla wszystkich stron. Prowadziłoby to do powstania wolnych społeczeństw, mniej wydajnych od społeczności niewolniczych - w efekcie otrzymalibyśmy suboptymalność Pareto.

Zapewne da się wskazać odzwierciedlenie tego rozumowania w dziedzinie wolnego handlu. Otóż nawet, jeżeli wolny handel, podobnie jak niewolnictwo, cechuje się większą wydajnością, czyli jest grą o sumie dodatniej, to - zupełnie jak w ustroju niewolniczym - ponad 100\% zysków przechwytywanych jest przez garstkę graczy, podczas gdy pozostali ponoszą straty. Sam fakt, że istnieje możliwość takiej redystrybucji, przy której zyskaliby wszyscy, nie gwarantuje bynajmniej, że taka redystrybucja będzie realizowana ani nawet tego, że ktoś choćby podejmie taką próbę.

Poruszone tutaj problemy są poważne. Każdy z osobna wystarcza, by przeważyć korzyści, na jakie powołują się zwolennicy wolnego handlu. A jednak wiele autorytetów w środowisku ekonomicznym bądź odmawia zajęcia się nimi, bądź nawet nie przyjmuje ich do wiadomości (w szczególności dotyczy to konsekwencji braku autonomii, dynamicznego charakteru przewagi komparatywnej oraz braków w zakresie efektywności Pareto). 
Rozważania te pociągają debatę na temat wolnego handlu w dwóch przeciwnych kierunkach. Na poziomie powierzchownym wolny handel wydaje się przynosić korzyści wszystkim uczestnikom, jednakże na głębszym poziomie pozory te rozwiewają się. Długoterminowa dynamika przewagi komparatywnej może przeważać, czyli uchylać wszelkie bezpośrednie korzyści płynące z wolnego handlu. Destabilizujące efekty krótkoterminowego kapitału spekulacyjnego mogą zniechęcać do inwestowania. W dodatku, nawet gdyby wolny handel miał podnosić poziom łącznej produkcji, to braki w zakresie efektywności Pareto moga spowodować, że większość ludzi w końcowym efekcie i tak zubożeje.

W praktyce ważne umowy handlowe są zawierane w tajemnicy i realizowane dla stojących za nimi interesów potężnych korporacji. Te zaś na ogół usiłują przechwycić dla siebie ze wszelkich korzyści tyle, ile tylko się da. Nawet jeżeli dana umowa przechodzi test zwiększania przeciętnej produktywności i łącznej produkcji, to przechwycenie ponad $100 \%$ korzyści przez nielicznych zubaża wszystkich pozostałych.

Zjawiskiem powszechnym jest to, że jeden kraj zostaje w takich relacjach całkowitym zwycięzcą, podczas gdy jego partnerzy handlowi tracą. Równie powszechne jest to, że w każdym kraju wskazać można garstkę wygrywających i rzeszę przegranych. To z kolei przekłada się na swoisty rozkład zwolenników i przeciwników wolnego handlu w całym zakresie możliwych postaw - zarówno pośród krajów jako całości, jak i wśród ich obywateli. Normą jest to, że zwolennicy są mniej liczni, lecz za to lepiej zorganizowani, lepiej finansowani, z lepszymi koneksjami i większą motywacją, a więc aktywniejsi niż przeciwnicy. Co więcej, zwolennicy znajdują potężne wsparcie w środowisku biznesowym, akademickim i politycznym.

Oddzielną kwestią w kontekście zwolenników wolnego handlu jest siła lobbystów finansowanych przez korporacje, zwłaszcza w Stanach Zjednoczonych². Widać to także w pracach akademickich, których wnioski „usłużnie” odzwierciedlają interesy korporacji fundujących dane badania ${ }^{3}$. Wreszcie, mamy z tym do czynienia również w polityce, gdy Prezydent Stanów Zjednoczonych, Donald Trump, na stanowiska w Federalnej Agencji Ochrony Środowiska mianuje osoby bezpośrednio powiązane z przemysłem węglowym, naftowym i gazowym, te zaś robią wszystko, by uchylić wszystkie decyzje podjęte wcześniej w dziedzi-

2 Przykładem jest przemysł tytoniowy opłacający lobbystów, by bez zastrzeżeń promowali jego produkty, pomimo ostrzeżeń głównego lekarza federalnego o zgubnych konsekwencjach palenia tytoniu.

3 Przypadek przemysłu mięsnego, gdzie w sponsorowanych badaniach zachęca się do maksymalnego spożycia mięsa, podczas gdy przytłaczająca większość badań wykonanych przez niezależnych dietetyków wskazuje na ogromne zagrożenia dla zdrowia wynikające z takich nawyków żywieniowych. 
nie ochrony środowiska przez administrację Prezydenta Obamy. Ich działania przyśpieszają oczywiście proces globalnego ocieplenia.

\section{Przegrani z czterech sektorów}

Ogólnie biorąc, globalizacja i wolny handel przynoszą korzyści kapitałowi kosztem siły roboczej, rządów, środowiska naturalnego i globalnego zdrowia socjo-politycznego.

Siła robocza jest przegranym bezpośrednim. Rzesze pracujące w krajach o stosunkowo wysokich płacach, regulowanych w proporcji do wysokiej produktywności, narażone są na przenoszenie zatrudnienia za granicę. Grozi im nawet utrata pracy, przekazywanej w ręce globalnej siły roboczej w celu obniżenia płac i przejęcia korzyści przez kapitał.

Konsekwencje tego zjawiska odczuwane są przez rządy i przez obywateli państw. Korporacje, dążące do maksymalizowania zysków po opodatkowaniu i korzystające ze swobody przenoszenia się do rajów podatkowych, mają i motywację, i warunki, aby tak postępować. Koncern Apple Computer wynegocjował dla siebie w Irlandii stawkę podatku dochodowego na poziomie 0,005\% i przepuścił ogromną część swoich zysków przez fikcyjne korporacje w tym kraju, aby drastycznie obniżyć płacone przez siebie podatki (Stiglitz, 2018). Kraje pozbawiane podatków dochodowych od korporacji zmuszone są albo do cięcia wydatków na infrastrukturę (w tym struktury zabezpieczenia społecznego), albo do zwiększania obciążeń podatkowych dla swoich obywateli fizycznych.

Wśród innych powiązanych problemów wymienić można deficyt działań w zakresie przekwalifikowania siły roboczej z branż redukujących zatrudnienie. W Stanach Zjednoczonych przemysł węglowy podupada, a przyszłość energetyki rysuje się w sektorze źródeł odnawialnych, który daje zatrudnienie o wiele większe niż przemysł naftowo-petrochemiczny, a jego pracownicy wymagają szkoleń, by mieć przed sobą przyszłość zawodową.

Kolejnym przegranym jest środowisko naturalne oraz ci wszyscy, którzy są od niego uzależnieni. Przestrzeganie przepisów w tej dziedzinie często jest kosztowne. Firmy mogą zwiększać swoje zyski, obniżając te koszty poprzez przenoszenie zakładów na obszary o niższych standardach ochrony środowiska. W Stanach Zjednoczonych lobbowanie (i to skuteczne) rządu federalnego na rzecz zwolnienia producentów produktów naftowych i gazu (stanowią oni źródło jednej trzeciej zanieczyszczeń środowiska metanem) od obowiązujących uprzednio 
norm redukcji emisji metanu przyśpiesza zmiany klimatu, ale korzystnie wpływa na zyski producentów węglowodorów (Davenport, 2018).

Handel światowy jako element globalnej produkcji gospodarczej wykazał w ostatnich dekadach nagły wzrost, od około $20 \%$ w końcu lat dziewięćdziesiątych do $60 \%$ obecnie. Jednocześnie, w wielu krajach zaznaczyła się epokowa przemiana w zakresie nierówności społecznych. Nierówności te malały od czasu zakończenia II wojny światowej, głównie w efekcie działań politycznych na rzecz tworzenia i umacniania struktur zabezpieczenie społecznego. Jednakże, w miarę jak rósł udział handlu w ogólnej produkcji ekonomicznej, coraz większa część korzyści zaczęła trafiać w ręce elit ekonomicznych.

Szukając powodów tego zjawiska, natrafia się na szereg związków przyczynowych. Jednym z nich jest pętla dodatniego sprzężenia pomiędzy handlem, który pierwotnie przynosił korzyści dla kapitału i budował majątek a tworzonym w ten sposób majątkiem i kapitałem, który wykorzystując wpływy polityczne, naciska na zwiększanie skali i intensywności wolnego handlu oraz na wprowadzanie innych środków politycznych korzystnych dla kapitału. Ten samonapędzający się proces prowadzi do koncentracji majątku.

Jednakże jaskrawe nierówności społeczne mają niszczący wpływ na ten zbiór postaw i idei, który od dawna był charakterystycznym, a być może również niezbędnym atrybutem demokracji. W konsekwencji tego w Europie byliśmy świadkami pojawiania się ultranacjonalistycznych partii politycznych, dochodzenia demagogów faszystowskich do władzy w kilku krajach, natomiast w Stanach Zjednoczonych - wyboru kandydata o postawie parafaszystowskiej na urząd Prezydenta (Albright, 2018).

Resentymenty leżące u podłoża tych ruchów ekstremistycznych mogą być słabo określone, niemniej można przyjąć, że znaczącą rolę przyczynową odegrała w tym zakresie świadomość wyraźnego wzrostu nierówności społecznych, pobudzanego przez wolny handel funkcjonujący już w skali globalnej. Wyjaśniałoby to dlaczego postawy faszystowskie pojawiały się po I wojnie światowej i pojawiają się dzisiaj, natomiast nie występowały po II wojnie światowej.

„W okresie pomiędzy dwiema wojnami światowymi wolnorynkowo nastawieni liberałowie rządzący Wielką Brytanią, Francją i Stanami Zjednoczonymi starali się przywrócić system laissez faire obecny przed pierwszą wojną. Pobór podatków przedkładali oni ponad odbudowę ekonomiczną krajów. Była to epoka drapieżnej spekulacji i braku kontroli nad prywatnym kapitałem. Wszystko to miało w założeniu zapewniać dobrobyt i pokój, tymczasem w rzeczywistości przyniosło dekadę niepewności ekonomicznej, ekstremalnych nierówności, dyskredytowania demokracji, reakcji faszystowskiej i pogłębiającej się depresji... 
Jak wykazał Polanyi w swoim doniosłym dziele z roku 1944, Wielka Transformacja, oderwanie rynków od ich społeczeństw i wynikające z niego ignorowanie społecznych konsekwencji nieodmienne pociagga za sobą reakcję. Reakcja taka jest zazwyczaj gwałtowna, a przez to częściej bywa chaotyczna i faszystowska niż demokratyczna i wyważona..." (Kuttner, 2018).

Po II wojnie światowej wiele krajów starało się wyciągnąć wnioski z własnych błędów, popełnionych w latach po poprzedniej wojnie. Stąd m.in. „wielka kompresja”, czyli okres złagodzenia nierówności ekonomicznych. Pokazuje to, jak wysokie stawki są $\mathrm{w}$ grze $\mathrm{w}$ tym kontekście i jak poważne są potencjalne konsekwencje zmierzania przez dłuższy czas w niewłaściwym kierunku ekonomicznym.

Nie trzeba być stronnikiem żadnej konkretnej doktryny politycznej, by dostrzegać wyraźne świadectwa tego, że kraje posiadające pluralistyczne instytucje polityczne i gospodarcze radziły sobie zdecydowanie lepiej od krajów, których gospodarka bazowała na instytucjach przemysłu wydobywczego (Acemoglu i Robinson, 2012).

Ze względu na naturalne cykle sprzężeń zwrotnych, bogactwo i władza mają tendencję do koncentracji (Piketty, 2014), co prowadzi do autokracji plutokratycznej w dziedzinie przemysłu wydobywczego. Niekontrolowany wolny handel sprzyja takiej koncentracji, migracji majątku z krajów uboższych do bogatszych, a w ramach poszczególnych krajach od ludzi biedniejszych do zamożniejszych. Polityka ekonomiczna zwiększająca nierówności społeczne generuje zarazem ryzyko wywołania procesów, które prowadzić będą do ekstremalnych koncentracji majątku w instytucjach przemysłu wydobywczego, ze szkodą dla społeczeństw jako całości i dla ogromnej większości ich obywateli.

\subsection{Kierunki na przyszłość}

Istnieje wiele kierunków ekonomicznych, w których możemy podążyć. $\mathrm{Na}$ jednym biegunie można by podważać albo po prostu ignorować krytykę wolnego handlu i postępować tak, jak gdyby stanowił on najlepszy ze wszystkich możliwych systemów w najlepszym z możliwych światów. Na drugim biegunie, można by okopać się na pozycjach autarkii. Wśród postaw środka można szukać takich środków kontroli handlu, które zapewnią ochronę uczestnikom słabszym i potencjalnie przegranym - nie tylko krajom, lecz także osobom fizycznym: tym, którzy, choćby i w najsilniejszych krajach, nie są równie sprawni, jak inni.

Pierwsza z tych możliwości wprawdzie nadal znajduje poparcie wśród wielu ortodoksyjnie nastawionych ekonomistów z kręgów akademickich, jednak jej popularność zdaje się spadać. Częściowo wpływają na to podnoszone wątpliwości odnośnie do standardowej teorii neoklasycznej. Założenia, na których 
opierają się jej zasadnicze modele, są wyraźnie fałszywe (np. ekonomia behawioralna), a historia prognoz gospodarczych stawianych z jej pozycji jest słaba.

Niektórzy ekonomiści, nawet odrzucający ortodoksję neoklasyczną, reagują na to argumentem, że modele takie da się udoskonalić tak, by tworzyć na ich podstawie trafniejsze prognozy. Z pewnością jest to możliwe. Tyle, że dla $k a \dot{z}$ dej pożądanej prognozy da się znaleźć jakiś model, który generuje ją lepiej. A co istotniejsze, tryb rozumowania właściwy dla tworzenia założeń (modeli) i generowania prognoz jako twierdzeń jest zupełnie różny od trybu rozumowania właściwego dla nauk w ogólności (Friedman, 2016; 2018). Współczesna teoria ekonomiczna nie jest teorią nauki.

Takie rozważania skłaniały niektórych komentatorów do uznania, że fiasko recept neoklasycznych stanowi wprawdzie fiasko teorii, ale niekoniecznie przesądza o niepowodzeniu krajów, w których teorie te realizowano. Diagnoza wskazująca spekulacyjne przepływy kapitałowe jako przyczynę lub co najmniej powód zaostrzenia kryzysu finansowego w Azji Wschodniej w roku 1997 pokazała poważne pęknięcie na pancerzu teorii neoklasycznej.

Często spotykanym zjawiskiem jest to, że kiedy pewna pozycja ekstremalna traci siłę dominującą lub nie daje się dłużej podtrzymać, do natarcia rusza przeciwstawna ekstrema. Wielu amerykańskich neokonserwatystów to osoby nawrócone z ekstremy przeciwnej, marksistowskiej. Podobne zjawisko może zachodzić w domenie handlu. Wielu ludzi, widocznie nagle uwrażliwionych przez wizję utraty miejsc pracy z powodu importu, wydaje się nie dostrzegać przyrostu miejsc pracy następującego w efekcie eksportu bądź sposobności przekwalifikowania się do pracy w sektorach rosnących, takich jak sektor odnawialnych źródeł energii. Za pożądane rozwiązanie uważają oni albo wyeliminowanie handlu, albo prowadzenie go jedynie na warunkach tak korzystnych, że całkiem nierealnych.

Stanowisko takie trudno byłoby uzasadnić na gruncie ekonomicznym. Jednak politykom często brakuje kompetencji ekonomicznych, natomiast przekonanie, że własny kraj stał się ofiarą (i został nią z winy obcych, nie zaś przez błędy swoich elit ekonomicznych) od dawna okazuje się skutecznym narzędziem manipulacji politycznej. Resentymenty oparte na przekonaniu, że obcy uczynili z nas ofiarę, są silną i niebezpieczną negatywną emocją. W historii aż roi się od konsekwencji rozsiewania takich negatywnych uczuć zbiorowych.

Powyższe nie przeczy temu, że jedni uczestnicy świata ekonomicznego istotnie czynią ofiary z innych. Tyle tylko, że architektami jednostronnych i nieuczciwych umów handlowych są potężne korporacje z solidnym umocowaniem politycznym, które wynegocjowały nieprzejrzyste warunki handlowe dla realizacji swoich interesów, a kosztem obywateli swojego, jak również innych krajów. Słowem, wiktymizacja faktycznie ma miejsce, ale Stany Zjednoczone lub co naj- 
mniej amerykańskie korporacje wielonarodowe i ich polityczni poplecznicy są w tym zjawisku raczej stosującym przemoc drapieżnikiem niż ofiarą. Jednak są one jednocześnie głównymi fundatorami amerykańskich partii politycznych, dlatego tak łatwo przychodzi im odwrócenie oskarżycielskiego palca w inną stronę.

Na szczeblu krajowym szefowie koncernów tytoniowych od dawna wiedzieli, że ich produkty są uzależniające i rakotwórcze. Okłamywali oni w tej sprawie Kongres, jednocześnie dokładając starań, by ich produkty stawały się jeszcze bardziej uzależniające (Hilts, 1996). Jednak na szczeblu międzynarodowym „... Koncern Philip Morris... pozwał w 2010 r. Urugwaj, ponieważ państwo to uchwaliło przepisy, które zobowiązywały producenta do ujawnienia możliwych szkodliwych skutków zdrowotnych palenia papierosów" (Stiglitz, 2018, s. 36).

$\mathrm{Na}$ szczeblu krajowym wiele społeczności podejmuje działania na rzecz ochrony swojego środowiska naturalnego, a w szczególności ujęć wody. Jednak na szczeblu międzynarodowym „Kiedy, na przykład, wieś leżąca w meksykańskim stanie San Luis Potosi, w północno-środkowej części tego kraju, próbowała zmusić amerykańską firmę Metalclad zajmującą się gospodarką odpadami do zamknięcia toksycznego wysypiska, źródła skażenia lokalnych ujęć wody, rząd Meksyku skazano na zapłatę odszkodowania w wysokości 16,7 mln dolarów na mocy postanowień Rozdziału 11 porozumień NAFTA. Lobby antyśrodowiskowe odniosło sukces, zdołało bowiem ukryć w tym rozdziale postanowienie, którego celem było torpedowanie regulacji proekologicznych poprzez windowanie ich kosztów do poziomów nie do przyjęcia... Do dnia dzisiejszego w oparciu o ten rozdział wszczęte zostały postępowania sądowe o odszkodowania na kwoty przekraczające 13 miliardów dolarów” (Stiglitz, 2006, s. 130, 197).

Prawa własności intelektualnej mają szczególnie duże znaczenie w sektorze medycznym/farmaceutycznym. $\mathrm{Z}$ jednej strony, sektor ten potrzebuje praw własności intelektualnej do ochrony swoich inwestycji w prace badawczo-rozwojowe, aby być w stanie odzyskać poniesione wydatki (Dewan, 2010). Z drugiej zaś - firmy z tej branży często wyceniają leki ratujące życie na poziomie, który pozostaje poza zasięgiem ludności uboższych krajów, a w dodatku tak naginają prawa własności intelektualnej, by powołując się na nie „wykradać” tradycyjne lekarstwa, od dawna używane przez wiele miejscowych społeczności.

Na poziomie krajowym, jeżeli ludzie od dawna używali danego produktu, to firma, która nie miała żadnego udziału w opracowaniu tego produktu, nie może nabyć chroniących go praw patentowych. Jednak w wymiarze międzynarodowym „W porozumieniu o bioróżnorodności, podpisanym w roku 1992 na Konferencji ONZ (Szczycie Ziemi) w Rio de Janeiro, uznano prawo do wynagrodzenia, ale Stany Zjednoczone, częściowo pod naciskiem koncernów farmaceutycznych, nie ratyfikowały tej umowy. I nie ma się czemu dziwić, biorąc 
pod uwagę, że prawie połowa z 4000 patentów roślinnych przyznanych w ostatnich latach przez Stany Zjednoczone, dotyczy tradycyjnej wiedzy, uzyskanej od krajów rozwijających się...

To, czego w tym kontekście domagały się Stany Zjednoczone, naszym zdaniem nie leżało w interesie obywateli tego kraju. Ani w interesie postępu naukowego, a już z pewnością nie w interesie krajów rozwijających się. Jednakże amerykańscy i europejscy negocjatorzy reprezentowali interesy sektorów farmaceutycznego i rozrywkowego, a także innych, którym zależało po prostu na zapewnieniu jak najsilniejszych praw własności intelektualnej (w badaniu zrealizowanym przez Center for Public Integrity - rządowy ośrodek nadzorujący, wykazano, że najsilniejszą grupą nacisku był przemysł farmaceutyczny...).

Jednak TRIPs (Porozumienie w sprawie Handlowych Aspektów Praw Własności Intelektualnej) zaprojektowane zostało po to, aby umożliwić dyktowanie wyższych cen leków. Jego skutkiem było, że ceny te znalazły się poza zasięgiem niemal wszystkich $-\mathrm{z}$ wyjątkiem osób najzamożniejszych. Ministrowie handlu, którzy podpisywali TRIPs, byli tak zadowoleni z siebie, że nie zauważyli, iż swoje podpisy stawiają na wyroku śmierci na tysiące ludzi w uboższych krajach świata" (Stiglitz, 2006, s. 105, 116, 125-6).

Państwa na ogół mają możliwość obejścia patentów w sytuacjach alarmowych w skali narodowej. Jednak w skali międzynarodowej: „W roku 1998 Prezydent Nelson Mandela podpisał ustawę, która miała zezwalać firmom farmaceutycznym z Republiki Południowej Afryki na produkowanie generycznych odmian leków na AIDS. Zakładano, że Stany Zjednoczone uznają tę ustawę za zgodną z postanowieniem Światowej Organizacji Handlu, które dopuszcza „przymusowe wydanie licencji w wypadkach naglących szczebla narodowego". Tymczasem Amerykanie na wszystkich poziomach administracji rządowej zaatakowali... propozycję RPA i to pomimo faktu, że koncern Glaxo wykorzystuje lek wynaleziony przez służby rządowe (lek AZT został opracowany przez badaczy z Michigan Cancer Institute i Duke University, którzy otrzymywali na te prace granty z National Cancer Institute)" (Adler, 2010, s. 78-79).

Pewne nadzieje wzbudza fakt, że w Stanach Zjednoczonych zachodzą przemiany w zakresie akceptacji leków generycznych, co w kontekście patentów i globalizacji jest zjawiskiem pozytywnym. Badacze pracujący dla Programu Regulacji, Terapeutyki i Prawa (Program on Regulation, Therapeutics and Law, skr. PORTAL) przy Harvard Medical School wspólnie z lekarzami z Brigham \&Women's Hospital w przedstawionym niedawno studium wykazali, że około połowa spraw, w których firmy produkujące leki generyczne protestowały, na mocy nowej procedury administracyjnej dotyczącej ważności patentów, a stworzonej przez Kongres Stanów Zjednoczonych, przeciw produktom farmaceu- 
tycznym chronionym przez FDA (amerykańską Agencję Żywności i Leków), zakończyła się zwycięstwem tychże producentów (New, 2018).

Jednakże roszczenie patentowe zgłoszone przez kalifornijski uniwersytet UCLA w Sądzie Najwyższym Indii w imieniu dużych koncernów farmaceutycznych Pfizer i Astellas pokazuje inne oblicze globalizacji. Lek na raka prostaty został opracowany na UCLA, ale sprzedawany jest poprzez firmy farmaceutyczne za cenę równą $20 \%$ mediany rocznych dochodów ludności Indii. Kraj ten, który z takim powodzeniem zabiegał o promowanie leków generycznych, pod presją wywieraną przez UCLA być może orzeknie o podtrzymaniu patentu, co sprawi, że lekarstwo stanie się niedostępne dla milionów chorych. Opinia publiczna zauważa, że UCLA jest instytucją publiczną finansowaną przez amerykańskich podatników. Studenccy aktywiści usiłują skłonić Uniwersytet do rezygnacji z roszczenia patentowego, którego konsekwencją może być pozbawienie nawet miliardów ludzi w krajach rozwijających się dostępu do leków po racjonalnej cenie (Branigan, 2018).

Wszystkie podane przykłady ilustrują, jak wielonarodowe korporacje szukają zysku kosztem krajów rozwijających się. Nie brakuje jednak innych cech i zjawisk globalnego handlu wolnorynkowego, które wypaczają grę rynkową i krzywdzą słabsze kraje jeszcze bardziej niż czynią to machinacje korporacyjne ukryte w warunkach konkretnych umów handlowych.

Niekontrolowane krótkoterminowe przepływy kapitałowe, w których spekulacja nasila przebieg naturalnych cykli, działają na niekorzyść gospodarek, w których funkcjonują. Chcąc bronić własnych walut przed wahaniami wywołanymi przez spekulantów, państwa zmuszone są kupować kosztowne ubezpieczenia - płacąc za nie w obcych walutach, najczęściej w dolarach amerykańskich. Takie zamrożone zasoby dolarowe, które w przeciwnym razie mogłyby zasilać rozwój gospodarczy, są oprocentowane na minimalnym poziomie, podczas, gdy odnośne państwo musi zazwyczaj pożyczać fundusze oprocentowane znacznie wyżej, by finansować nimi rozwój kapitałowy. Takie różnice oprocentowania, rzutowane na olbrzymie kwoty kapitału w grze, są żyłą złota dla sektora finansowego Stanów Zjednoczonych, jednak odbywa się to kosztem krajów, które muszą wykupywać tego typu ubezpieczenie.

I kolejna, pokrewna kwestia: wiele krajów rozwijających się obciążonych jest ogromnymi długami denominowanymi w dolarach amerykańskich. Kiedy Rezerwa Federalna z racji czysto krajowych (wewnętrznych) podnosi stopy procentowe, wartość dolara wzrasta. Wraz z nią rosną zobowiązania zadłużonych krajów. Zjawisko to może mieć destabilizujący wpływ na gospodarki rozwijające się. Powiązanie wartości ich walut $\mathrm{z}$ kursem dolara amerykańskiego może nie być rozwiązaniem zadowalającym, ponieważ jest to operacja kosztowna, a jeżeli 
dolar amerykański jest silny, to takie powiązanie kursowe wpływa niekorzystnie na pozycję konkurencyjną kraju rozwijającego się.

Mechanizmy takie często traktuje się jako bezrefleksyjną oczywistość, warto jednak uświadamiać sobie ich efekt kumulacyjny.

Niezależnie od tych zjawisk, niektóre państwa, obecnie Chińska Republika Ludowa, prowadzą różnego rodzaju drapieżne taktyki handlowe, od nakładania wysokich taryf celnych na dotacje rządowe dla faworyzowanych sektorów po zwyczajne szpiegostwo przemysłowe. Tego typu przestępstw dopuszczało się wiele krajów, wśród nich Singapur, Korea Południowa, Japonia, Niemcy (w XIX w.), a także - nie da się ukryć! - Stany Zjednoczone. My jednak wydajemy się nieświadomi historii: agresywne instytucje nie przeszkadzają nam, gdy działają z ramienia potęg gospodarczych, ale kiedy próbę zyskania przewagi podejmują kraje rozwijające się, od razu wyrażamy swoje oburzenie.

Uświadomienie sobie tych zjawisk, czy nawet wyciągnięcie z nich wniosków, nie jest jeszcze tożsame ze znalezieniem skutecznych środków zaradczych dla ich rozwiązania. Niemniej, jest to istotne, sugeruje bowiem bardziej funkcjonalny sposób ich traktowania. Rozwinięte kraje uprzemysłowione mają miażdżącą naturalną przewagę nad krajami, które dopiero usiłują się rozwinąć.

Historycznie biorąc, gospodarki doganiające, które odniosły sukces, stosowały szereg środków i taktyk, przy użyciu których starały się wyrównać grę. Środki te miały różnoraki charakter - od manipulacji walutowych przez zapory celne, po szpiegostwo przemysłowe. Ten ostatni proceder też przybierał różne oblicza: od zwyczajnej kradzieży po angażowanie dobrze umocowanych ekspertów w dziedzinach technologii, kaptowanych z krajów wysoko rozwiniętych; od metod typu de-engineering i re-engineering po żądanie udostępnienia technologii i wyłącznych praw do patentów na wspólnie opracowane produkty w zamian za dostęp do dużych rynków konsumenckich.

\section{Podsumowanie}

Czy możliwe jest dokonanie przekonującego rozróżnienia pomiędzy takimi metodami politycznymi, jakie można uznać za uprawnione a tymi, które uznamy za bezwzględnie nieuprawione? I kolejne, niezależne pytania: czy istnieją programy lub inicjatywy partnerskie być może obejmujące dzielenie się technologiami, które państwa bardziej zaawansowane mogłyby zaoferować dla przyśpieszenia wzrostu gospodarczego zarówno u siebie, jak i w krajach rozwijających się? Czy istnieją sposoby pobudzenia dodatkowego wzrostu gospodarczego, 
który przyniósłby korzyści jak największej liczbie ludzi? Skoro niektóre kraje nie są w stanie w pojedynkę zapewnić sobie wystarczających korzyści, by uzasadnić dokonywane przez siebie inwestycje, to czy instytucje wielonarodowe mogą działać katalizująco w tym zakresie, generując taką pętlę sprzężenia zwrotnego, w wyniku której zwiększony wzrost gospodarczy danych krajów wywoła pozytywny wpływ na wzrost ich krajów ościennych?

Oto pytania, jakie zapewne powinni zadawać sobie ci, którzy poszukują dróg i rozwiązań pośrednich, czyli handlu racjonalnie regulowanego. Wydaje się, że właśnie takie rozwiązania stanowią kierunek najrozsądniejszy, choć zarazem najtrudniejszy i najbardziej złożony.

Jedną z kwestii implikowanych przez wybór takiego kierunku jest pytanie o granice polityki handlowej. Przykładowo, czy umowy handlowe powinny zawierać warunki podatkowe? Czy warunki takie powinny stanowić barierę powstrzymującą korporacje przed minimalizowaniem płaconych podatków metodą sztucznego lokowania swoich zysków w rajach podatkowych? Korporacje wielonarodowe można by opodatkowywać tam, gdzie ma miejsce końcowa sprzedaż produktów konsumentom, po stawkach obowiązujących w krajach, w których dane produkty lub usługi są sprzedawane. Skutkiem użycia takiej zasady byłoby, na przykład, uniezależnienie podatku dochodowego płaconego przez producenta samolotów, od tego, gdzie posiada on swoją oficjalną siedzibę lub gdzie siedzibę posiada linia lotnicza kupująca jego maszyny. W efekcie, kraje mogłyby żądać tego, ażeby korporacje, które osiągają zysk ze sprzedawania u nich towarów i usług również u nich płaciły podatki dochodowe. Podobne podatki można by wprowadzić od inwestycji. Takie procedury chronityby rządy i obywateli odnośnych państw przed pozbawieniem wpływów z podatku dochodowego od osób prawnych.

Umowy handlowe mogłyby przyczyniać się do ochrony środowiska poprzez uznanie sztucznie poluzowanych norm środowiskowych za tworzenie nieuczciwej przewagi dla producentów - przewagi, którą można by skutecznie zwalczać instrumentami celnymi.

W podobny sposób może być możliwe domaganie się standardów minimum w zakresie zatrudnienia: ich naruszanie byłoby uznawane za generowanie nieuczciwej przewagi i zwalczane metodami celnymi.

Pewien zakres ochrony konsumenta można by osiągnąć poprzez zobowiązanie do przejrzystości: na przykład w takim znaczeniu, że państwa mają prawo, a może nawet obowiązek, testować produkty i upubliczniać ich ewentualne szkodliwe lub niebezpieczne właściwości.

Wnioskiem z niniejszych rozważań mogą zatem być pewne minimalne środki ochronne. Kolejne, bardziej rozbudowane, da się stworzyć dzięki starannemu 
dopracowaniu formy proponowanych metod. W szczególności, wydaje się rozsądne i wskazane żądanie nie tylko przejrzystości, ale także rzetelnej, wiarygodnej reprezentacji dla i w imieniu tych stron, które bywają najbardziej narażone na niekorzystne potraktowanie - to znaczy ludności pracującej, środowiska naturalnego, rządów państw i ogółu konsumentów.

\section{Bibliografia}

Acemoglu, D. i Robinson, J. (2012). Why Nations Fail: The Origins of Power, Prosperity, Poverty. New York: Crown Business.

Albright, M. (2018). Fascism: A Warning. New York: Harper Collins.

Branigan, D. (2018). 'Student Activists Swarm To Demand UCLA Drop Indian High Court Patent Claim. Intellectual Property Watch online, 6 September.

Cohen, S. i DeLong, J.B. (2016). Concrete Economics: The Hamilton Approach to Economic Growth and Policy. Cambridge: Harvard Business Review Press.

Davenport, C. (2018). Trump Administration Wants To Make It Easier To Release Methane Into The Air. New York Times, 10 September.

Dewan, M. (2010). Socio-economic changes effected by intellectual property rights: the Indian perspective. W: R. Taplin, A.Z. Nowak (red.), Intellectual Property, Innovation and Management in Emerging Economies. Oxon: Routledge.

Fogel, R. i Engerman, S. (1974). Time on the Cross: The Economics of American Negro Slavery. New York: W.W. Norton and Company.

Friedman, K. (2016). Econoclastics 201: Meta-economics - Is Economics a Science? Interdisciplinary Journal of Economics and Business Law, 5(3), 76-101.

Friedman, K. (2018). Structural Failures and Non-structural Defects of Economic Theory. Interdisciplinary Journal of Economics and Business Law, 7(3).

Kuttner, R. (2018). Can Democracy Survive Global Capitalism? New York: W.W. Norton and Company.

New, W. (2018). Study: Generic Drug Industry Embraces Faster, Cheaper Pathway For Challenging Patents. Intellectual Property Watch online, 6 September.

Nixon, R. (2018). Smuggling of US Technology Outpacing Cold War Levels Experts Say. New York Times, March 17.

Piketty, T. (2014). Capital in the Twenty-first Century. Cambridge: Harvard University Press.

Rodrik, D. (2011). The Globalization Paradox: Democracy and the Future of the World Economy. New York: W.W. Norton and Company.

Rodrik, D. (2017). Straight Talk on Trade: Ideas for a Sane World Economy. Princeton: Princeton University Press.

Stiglitz, J. (2006). Making Globalization Work. New York: W.W. Norton and Company.

Stiglitz, J. (2017). Globalization and Its Discontents Revisited: Anti-Globalization in the Era of Trump. New York: W. W. Norton and Company.

Taplin, R. (red.). (2016). Postscript' in Ruth Taplin. Managing Cyber Risk in the Financial Sector: Lessons from Asia, Europe and the USA. Oxon: Routledge. 


\title{
HARALD SANDER
}

\section{Europa w nowej ekonomii globalnej}

\begin{abstract}
Po niemal trzydziestoletnim okresie hiperglobalizacji, od czasu światowego kryzysu finansowego z lat 2008-2009 światowy proces integracji ekonomicznej stracił impet. Niemniej, niniejszy artykuł stwierdza, że ogłaszanie śmierci globalizacji byłoby przedwczesne, natomiast proces globalizacji zmienia swój charakter. Głównymi cechami „nowej ekonomii globalnej” są: cyfryzacja, powstawanie i szybki wzrost firm „superstar", rozwój gospodarek wschodzących oraz przemiany w geografii globalnych finansów. Jednocześnie, konsekwencje dystrybucyjne zarówno hiperglobalizacji w dawnej postaci, jak i zasadniczych struktur nowej ekonomii globalnej grożą osłabianiem lub nawet utratą wsparcia politycznego dla globalizacji $i$ wiążą się ze wzrostem fali populizmu w krajach rozwiniętych. Niniejszy artykuł uwzględnia wyzwania polityczne wyłaniające się z procesu globalizacji i na ich podstawie omawia możliwości politycznego reagowania ze strony Unii Europejskiej. Zdaniem autora, nie wystarczy skuteczne rozwiązywanie kwestii ekonomicznych i dystrybucyjnych, gdyż pilnym zadaniem dla osiągnięcia legitymizacji w Europie jest również przywrócenie równowagi i zdemokratyzowanie metod rządzenia Unią. Tylko pod tym warunkiem możliwe będzie zyskanie wiarygodności, aby móc działać w skali globalnej na rzecz ksztaltowania stabilnej i sprawiedliwej ekonomii globalnej.
\end{abstract}

Słowa kluczowe: cyfryzacja, firmy superstar, gospodarki wschodzące, globalne finanse, populizm, rządy europejskie.

\section{Wprowadzenie}

Globalizacja zwalnia. Towarzyszą temu nasilenie populizmu i powrót protekcjonizmu w dawnym stylu. Niniejszy artykuł jest próbą określenia najważniejszych przyczyn i objawów niedomagania globalnej integracji ekonomicznej oraz konsekwencji politycznych tego zjawiska z perspektywy europejskiej.

Od końca lat 80. XX wieku skala międzynarodowej działalności gospodarczej rosła w szybszym tempie niż produkcja globalna. Jednakże po światowym kryzysie finansowym (ŚKF) z lat 2008/2009 ta trwająca około 30 lat epoka „hiperglobalizacji” ustąpiła miejsca fazie, która bywa nazywana „nową normalnością”. Jej objawami są względny zastój w handlu i napływie bezpośrednich inwestycji zagranicznych (BIZ) w stosunku do skali produkcji oraz zastój 
i postawy zachowawcze w dziedzinie transgranicznych operacji finansowych, szczególnie w bankowości (zob. rys. 1). Autor niniejszego artykułu wyznacza sobie dwa zasadnicze cele. Po pierwsze, stawia i uzasadnia tezę, że ogłaszanie śmierci globalizacji byłoby obecnie przedwczesne, stwierdzając, że proces globalizacji jedynie zmienia swój charakter. Po drugie, analizuje następstwa „nowej ekonomii globalnej”, której świadkami jesteśmy obecnie i ocenia je z punktu widzenia polityki europejskiej.

Rysunek 1. Skala działalności transgranicznej w stosunku do globalnego PKB, 1980-2017 $(1980=100)$

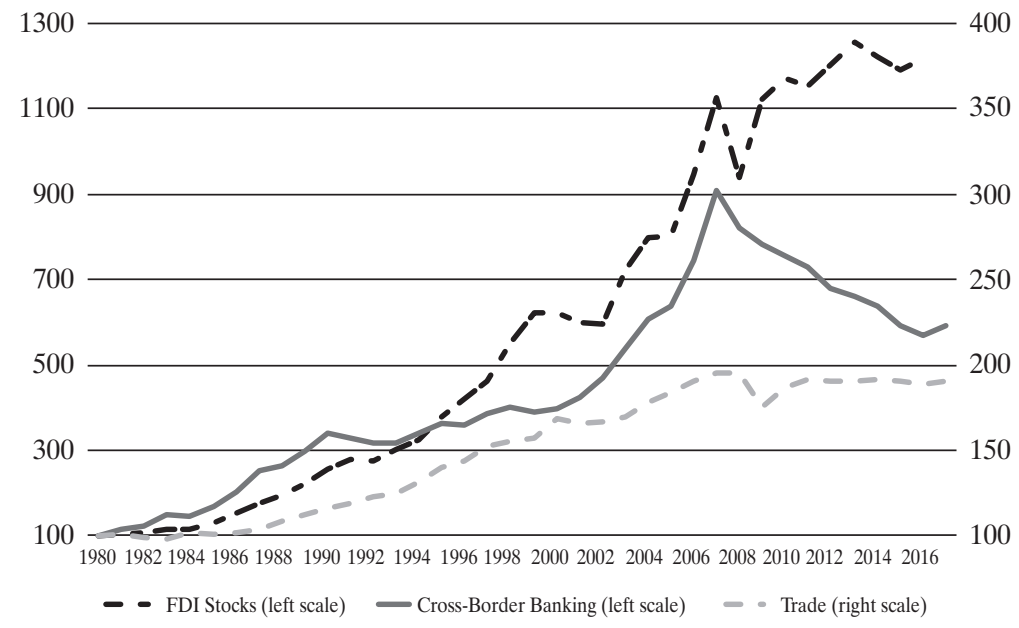

Źródło: obliczenia własne na podstawie IMF World Economic Outlook Database (PKB, Trade), UNCTAD (BIZ), i BIS Locational Banking Statistics (Cross-Border Banking).

Zasoby BIZ mierzone są jako średnia zapasów wewnętrznych i zewnętrznych. Wielkość bankowych operacji transgranicznych mierzona jest jako średnia zobowiązań i roszczeń w relacjach transgranicznych.

Podobnie jak w przeszłości, na tempo i charakter globalnej integracji ekonomicznej, a więc także na efekty tych zjawisk dla społeczeństw wpływać będą interakcje pomiędzy postępem technicznym a polityką. $Z$ punktu widzenia techniki przemiany światowej gospodarki będą w największym stopniu kształtowane przez procesy cyfryzacji i robotyzacji - w stopniu porównywanym do wpływu, jaki w krajach rozwiniętych w latach 1870-1914 wywierał silnik parowy, a w okresie po roku 1990 - techniki informatyczne. Z punktu widzenia polityki, euforia wywołana otwarciem zachodzącym w latach 90 . XX wieku i pierwszej dekadzie nowego stulecia, uznawanym przez tzw. konsensus waszyngtoński za panaceum 
na wiele, jeśli nie wszystkie bolączki ekonomiczne (Williamson, 1990), mocno przybladła po tym, jak ŚKF ujawnił wrażliwość gospodarek ściśle powiązanych ze sobą relacjami finansowymi. Co więcej, i postęp techniczny, i globalizacja stanowią zagrożenie dla poziomu życia nie tylko ludzi o niskich kwalifikacjach: ich wpływ coraz mocniej penetruje w głąb klasy średniej. Jednocześnie ruchy populistyczne w wielu krajach rozwiniętych w coraz większym stopniu wyzwalają polityczny gniew i sprzeciw wobec globalizacji. Nową popularnością cieszy się tradycyjny protekcjonizm, wspomagany przez odradzające się podpowierzchniowo ruchy nacjonalistyczne. Uważnym obserwatorom zjawiska te niepokojąco kojarzą się z ponurym obliczem doby międzywojennej i nasilaniem postaw, które nieco później przyczyniły się do zdruzgotania światowego ładu ekonomicznego. Czy populizm i nacjonalizm powtórzą swój niszczący wpływ na światową gospodarkę? - będzie to w decydującym stopniu zależeć od tego, w jaki sposób twórcy polityki poradzą sobie z dwojakimi zagrożeniami, wynikającymi z techniki i z globalizacji.

W niniejszym artykule zbadano te kwestie z perspektywy europejskiej. W części 2 starano się ogólnie rozpoznać główne obecne i przyszłe siły sprawcze procesu globalizacji, a w szczególności określić ich wpływ na Europę. Na podstawie tej analizy, w części 3 naszkicowano związki pomiędzy globalizacją a wzrostem populizmu, znowu głównie w Europie. W części 4 omówiono dostępne na tym kontynencie opcje polityczne i poszukiwania reformy Unii Europejskiej w celu jej przygotowania na wyzwania rozwijającej się nowej ekonomii globalnej. Ostatnia, piąta część artykułu zawiera podsumowanie i wnioski.

\section{Ku nowej ekonomii globalnej}

\subsection{Powstanie globalnych łańcuchów wartości}

Od połowy lat 80. XX wieku postępy techniczne w dziedzinie teleinformatyki oraz globalne naciski polityczne domagające się deregulacji i otwarcia gospodarek umożliwiły korporacjom szybkie globalizowanie się. Wraz z nadejściem doby CAD (projektowania komputerowego), numerycznego sterowania procesami produkcji i ogólnego komputerowego wkładu w wytwórczość nagle możliwe stało się „poszatkowanie” łańcuchów wartości. Produkcję danego produktu można było rozdzielić na szereg poszczególnych zadań w taki sposób, by następowały one niezależnie od siebie, a zarazem dokładnie pasowały do siebie, umożliwiając gładki końcowy montaż. Dzięki temu produkcja wielu towarów nie 
musiała już odbywać się w murach jednej fabryki. Te nowe możliwości podziału łańcucha wartości wykorzystywane są wszędzie tam, gdzie podział taki przynosi zysk. Naturalnie, nie przesądza to jeszcze o zasięgu takiego podziału, który może zachodzić w skali jednego kraju bądź nawet niedużego regionu. W efekcie częstym zjawiskiem stało się także zlecanie czynności produkcyjnych w ramach danego kraju. Jednakże ze względu na znacznie większe różnice w zakresie kosztów produkcji oraz wielkie zróżnicowanie kompetencji i specjalizacji w skali globalnej, globalizacja łańcuchów wartości często pozwala uzyskać o wiele większą wydajność i daje lepsze sposobności biznesowe niż stosunki czysto krajowe. To zresztą zależy od jeszcze jednego czynnika - od rozsądnych kosztów łączności i przekazu informacji. I właśnie ten czynnik odegrał kluczową rolę w okresie po roku 1990: rosnące możliwości podziału łańcuchów wartości zbiegły się z radykalnym spadkiem kosztów łączności i przekazu informacji. W efekcie łańcuchy wartości zostały nie tylko podzielone, lecz także rozrzucone po wielu dalekich krajach, dając początek temu, co z czasem nazwano globalnymi łańcuchami wartości (GŁW). Przenoszenie produkcji podzielonej na szereg czynności zachodzi na kolosalną skalę od końca lat 80., w dużym stopniu pobudzane przez BIZ. Gospodarki wschodzące, zwłaszcza w krajach Azji Południowo-Wschodniej, które szybko zrozumiały, jak wiele mogą zyskać na tych inwestycjach, otworzyły się na wymianę handlową i na BIZ i pogłębiły treść swoich regionalnych umów o wolnym handlu. Niektóre kraje, jak Chiny, wyrazily chęć przystąpienia do Światowej Organizacji Handlu (WTO). To właśnie szczególnie te kraje mogły wynieść ogromne korzyści z tego nowego rodzaju „arbitrażu pracy” poprzez uczestnictwo w globalnych łańcuchach wartości najważniejszych branż, a zwłaszcza w przemyśle odzieżowym i elektronicznym. W Europie ważnym ogniwem regionalnych sieci produkcji głównych branż przemysłowych z krajów zachodnich stały się kraje Europy Środkowej i Wschodniej (ESW), zyskując istotną rolę m.in. w przemyśle motoryzacyjnym. $Z$ kolei na kontynencie amerykańskim meksykański przemysł Maquiladora zaczął coraz głębiej penetrować północnoamerykański łańcuch wartości.

Warto zauważyć, że globalne łańcuchy wartości są skoncentrowane regionalnie ${ }^{1}$. Na przykład, w przemyśle elektronicznym dostawcy komponentów

1 Odzwierciedleniem tego jest również tak zwana „zagadka odległości” widoczna w szacunkach modeli grawitacyjnych handlu. Model grawitacyjny zakłada, że handel pomiędzy dwoma krajami jest proporcjonalny do iloczynu skali ekonomicznej tych krajów i pozostaje w zależności odwrotnej względem dzielącej je odległości geograficznej. Zagadka odległości odnosi się do stwierdzenia, wynikającego $\mathrm{z}$ większości badań w zakresie modeli grawitacyjnych, że w ostatnich latach skutki znacznych odległości nie tylko utrzymują się, ale wręcz nasilają - pomimo spadku kosztów transportu i łączności komputerowej. Regionalne sieci produkcji w znacznym stopniu pozwalają wyjaśnić ten dylemat. 
i półproduktów w wielu wypadkach zlokalizowani są w jednym regionie, a konkretnie we wschodniej Azji. Sytuacja taka tworzy intensywną sieć relacji handlowych w ramach danego regionu, na stosunkowo krótkie odległości, w efekcie czego regionalne umowy handlowe stają się ważnym instrumentem politycznym w promocji regionalnych klastrów. Handel nabiera charakteru naprawdę globalnego dopiero wtedy, gdy produkt końcowy zostaje dostarczony na rynek konsumencki. Podobne zjawisko zaobserwować można w europejskim przemyśle motoryzacyjnym: branża ta, szczególnie w Niemczech, wykształciła regionalne sieci produkcji, najczęściej z udziałem krajów ESW.

Od czasu światowego kryzysu finansowego tempo wzrostu handlu i inwestycji zagranicznych spada. Dlaczego globalizacja zwalnia? Czy odzyska swój impet, a jeżeli tak, to w jakiej postaci? Inaczej mówiąc, czy jesteśmy świadkami jedynie czasowego impasu, czy zasadniczej przemiany strukturalnej? Obecne spowolnienie częściowo jest konsekwencją wielkiej recesji, jaka miała miejsce po ŚKF oraz - w Europie - w szczególności po kryzysie waluty euro, odczuwalnym od roku 2010. Jako takie, wydaje się ono jedynie skutkiem tymczasowym. Spotykane są również tezy, że GŁW weszły w fazę malejących przychodów: wszystko, co dało się podzielić, już zostało podzielone. Istotnie, rozwój GŁW ostatnio wykazuje stagnację. Udział zagranicznej wartości dodanej w handlu przez dwie dekady rósł - z poziomu 24\% w roku 1990 do $31 \%$ w 2010 - tymczasem przez siedem ostatnich lat zmalał do $30 \%$ w roku 2017. Należy jednak zauważyć, że w Europie udział ten nadal pozostaje bardzo wysoki, wynosząc 38\% (UNCTAD 2018).

Niemniej, spowolnienie w handlu, inwestycjach i tworzeniu GŁW może wynikać także z innych czynników technicznych, ekonomicznych i politycznych. Ażeby zrozumieć, w jakim kierunku światowa gospodarka podąży od stanu obecnego, przebadano cztery główne czynniki destabilizujące: cyfryzację, zachodzącą w związku z dalszymi postępami teleinformatyki, powstanie i gwałtowny wzrost firm typu superstar, pojawianie się coraz to nowych krajów o rynkach wschodzących i ich szybki wzrost, oraz kształtowanie się nowego wzorca finansów globalnych po ŚKF.

\subsection{Cyfryzacja}

O ile rozwijające się teleinformatyka i cyfryzacja umożliwiały podzielenie łańcucha wartości do niespotykanego wcześniej stopnia, o tyle potencjał cyfryzacji jest większy i wykracza poza samo tworzenie GŁW. Dziedzina ta zdolna jest zmieniać intensywność i charakter globalizacji poprzez takie instrumenty, jak robotyzacja, uczenie maszynowe czyli sztuczna inteligencja (AI) oraz zdol- 
ność do obniżania kosztów komunikacji osobistej poprzez zastosowanie technik rzeczywistości wirtualnej (VR) oraz rzeczywistości rozszerzonej (AR) (zob. Baldwin, 2016).

Przede wszystkim, robotyzacja z samej swojej natury nie skłania do relokowania produkcji za granicę, ponieważ procesy produkcji zrobotyzowanej można realizować równie dobrze w kraju, jak i za granicą. Różnica polega jedynie na tym, że w tym pierwszym wypadku robot zastąpi krajowe, a w drugim wypadku - zagraniczne miejsca pracy. Istotniejsze w kontekście robotyzacji jest to, w jaki sposób będzie ona wpływać na geografię globalnej produkcji. To z kolei zależeć będzie od wpływu robotyzacji na koszty produkcji. Przejście na produkcję maszynową nastąpi wtedy, gdy ceny maszyn (czyli kapitał) spadną w stosunku do kosztów pracy ludzkiej, jaką dane roboty miałyby zastąpić. W tym kontekście ważne są dwie obserwacje: po pierwsze, ceny kapitału rzeczywiście spadają (zob. np. Nordhaus, 2015), a po drugie, koszty pracy, szczególnie w gospodarkach wschodzących o szybkim tempie wzrostu, takich jak Chiny i inne kraje Azji Południowo-Wschodniej, rosną. Biorąc pod uwagę, jak wiele zadań zostało relokowanych za granicę, w dalekie regiony o niskich kosztach pracy, przemiany te mogą pobudzać relokację powrotną. Co więcej, proces taki może być wymuszany przez efekt wielkości rynku, skłaniający do przenoszenia produkcji bliżej konsumentów.

Należy pamiętać, że nawet inteligentne roboty nie są w stanie przejąć na siebie procesów produkcji w całości, a jedynie poszczególne zadania - w pierwszej kolejności te, które najłatwiej poddają się robotyzacji. W wydanym niedawno artykule Acemoglu i Restrepo (2018, s. 48) przedstawiają model automatyzacji na poziomie zadań. Badacze twierdzą, że technologiami najgroźniejszymi dla pracy ludzkiej „nie są te, które stanowią największy przełom i pozwalają wydatnie podnieść produktywność, lecz właśnie pośledniejsze - na tyle dobre, by je stosować, ale nie dość sprawne, by znacznie zwiększać produktywność". W efekcie tego relokacja zadań staje się zjawiskiem coraz bardziej rzeczywistym i to nie tylko w Europie. Marin i in. (2017) opisują zmienny wzorzec relokacji, wskazujący na to, że spowolnienie w handlu w ramach GLW następuje jako nowa postać globalizacji z firmami, które przebudowują swoje lańcuchy wartości w taki sposób, aby je skracać i nadawać im charakter bardziej lokalny lub regionalny. Autorzy ci dostrzegają też wymierne efekty relokacji i to nie tylko powodowane przenoszeniem produkcji przez firmy chińskie. W Europie zauważają oni znacznie mniejszą skalę relokacji z północnych do południowych krajów kontynentu - ruch taki zachodzi raczej w kierunku Chin i krajów ESW.

Sztuczna inteligencja (AI) jest drugim z głównych z potencjalnych czynników destabilizujących o charakterze technicznym. Uczenie maszynowe rozwija się 
szybko, powodując wręcz szokującą koncentrację regionalną - z jednej strony w Stanach Zjednoczonych, z drugiej strony w Chinach. Inaczej mówiąc, Europa jest w tych przemianach właściwie nieobecna, szczególnie w zakresie wykorzystania AI, które wymaga dostępu do olbrzymiej puli danych, by umożliwiać uczenie maszynowe. W ten sposób rolę dominującą przejmują dwa modele biznesowe: model komercjalizacji danych realizowany przez amerykańskie giganty w branży danych oraz model chiński „gromadzenia danych na szczeblu państwa”.

Trzecim potencjalnym źródłem zakłóceń i destabilizacji może być spadek kosztów bezpośredniej komunikacji osobistej (face-to-face), na co z naciskiem wskazuje Richard Baldwin (2016). Teleobecność, telekonferencje, telerobotyka, technologie VR i AR mogą obniżyć koszty, eliminując konieczność podróży. Dzięki temu kraje dotychczas słabo reprezentowane w globalizacji napędzanej przez GŁW, czyli w przemianach zachodzących przez ostatnich 30 lat, mogą zbudować nowe przewagi konkurencyjne oparte na różnicach kosztów pracy. Na dalszym etapie ewolucja ta może połączyć kraje odległe, takie jak Argentyna i odcięte od dogodnych szlaków kraje śródlądowe w Afryce i Azji, które do tej pory nie uczestniczyły w „wielkiej konwergencji” gospodarki światowej. Taka działalność transgraniczna rozwijać się będzie nie tylko w dziedzinie handlu towarami, lecz także w handlu siłą roboczą, a więc usługami i pracą, stanowiąc nową formę globalizacji.

\subsection{Nowe firmy globalne}

Gwałtownie rozwijające się globalne, cyfrowe przedsiębiorstwa wielonarodowe (MNE), handel dobrami niematerialnymi oraz BIZ dokonywane w celach optymalizacji podatkowej zyskują na względnym znaczeniu w wymianie transgranicznej kosztem tradycyjnego handlu towarowego i BIZ lokowanymi w wytwórczość.

Handel dobrami niematerialnymi obejmuje dwa nurty - handel usługami $i$ handel wiedza. Zaczynając od obserwacji najmniej efektownej, obecnie dobrze udokumentowany jest fakt, że ogólnie dominują BIZ w usługi - z udziałem przekraczającym $60 \%$. Wielkość ta jest zasadniczo zgodna z ogólnym udziałem usług w gospodarce światowej ${ }^{2}$. Natomiast widoczna w ubiegłym wieku tendencja do lokowania BIZ w usługach przestała rosnąć po kryzysie finansowym,

2 Należy jednak zauważyć, że dane nt. udziału usług są nieco zawyżone. Według UNCTAD (2017, s. 21), „globalne BIZ w sektorze usług w znacznej części plasują się w działalności biznesowej, włącznie z funkcjami wykonywanymi przez firmy holdingowe i bazy regionalne. Działania takie są domyślnie zaliczane do usług, nawet jeżeli odnośne spółki macierzyste działają w sektorze surowcowym lub produkcyjnym". 
co może sugerować, że usługi rozwijane dzięki BIZ są często bezpośrednio powiązane z działalnością wytwórczą albo działaniami w sektorze surowcowym (zob. rys. 2). Niemniej, jako że obecnie ponad połowa wszystkich strumieni BIZ w skali globalnej trafia do krajów rozwijających się i krajów przechodzących transformację, w których udział sektora usług jest stosunkowo niski, to jest to zarazem sygnałem, że kraje te zaczynają nadganiać czołówkę w zakresie usług.

Rysunek 2. Globalne zapasy wewnętrzne BIZ z podziałem na sektory, 2001, 2007, 2015

(w bilionach dolarów)

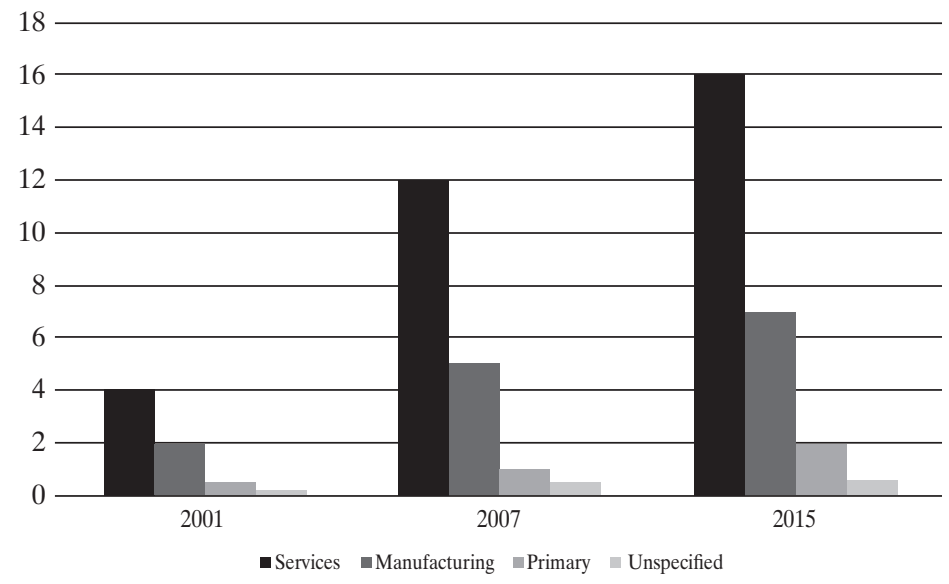

Źródło: UNCTAD, 2017, s. 21.

Przemiany strukturalne mają ostrzejszy przebieg w dziedzinie geografii wiedzy i handlu wiedzą. W przeszłości globalna pula wiedzy i technologii tradycyjnie skupiała się w krajach rozwiniętych. Ostatnio jednak wiedza w coraz większym stopniu pokonuje granice i pobudza błyskawicznie rozwijające się działania innowacyjne w gospodarkach wschodzących, w szczególności w Korei i Chinach, co dokumentuje niedawne badanie MFW oparte na statystykach patentowych (IMF, 2018). Wiedza zazwyczaj wędruje wraz z handlem, z BIZ, z migracją ludności i z innymi działaniami o charakterze transgranicznym. Oznacza to, że jej ruch jest bezpośrednio i pośrednio pobudzany przez postępy w teleinformatyce. Udział wiedzy w GŁW wydaje się odgrywać ważną rolę w jej przekazie i w działalności patentowej. Autorzy badania MFW stwierdzają, że „ogólny wpływ na działalność patentową w wydaniu przeciętnych firm jest pozytywny, jako że obserwowany wzrost udziału w GŁW o 1 procent co pięć lat wyjaśnia wzrost o jedną dziesiątą w zakresie działalności patentowej przeciętnych firm w takim samym okresie" (IMF, 2018, s. 15). W oparciu o dodatkową analizę cytatów 
między patentami autorzy dokumentują także wzrost wymiany handlowej knowhow oraz rosnące znaczenie handlu wiedzą w relacjach południe-północ oraz południe-południe.

Z punktu widzenia krajów rozwiniętych, tradycyjnie utożsamianych z rozwojem innowacji, transfer wiedzy jest mieczem obosiecznym. $Z$ jednej strony sprzedaż know-how staje się coraz ważniejszym źródłem dochodów i w ten sposób przynosi bezpośrednie korzyści spółkom tworzącym innowacje. Ponadto, skoro rozpowszechniona wiedza może pobudzać produktywność w kraju odbiorcy, to może również pośrednio przekładać się na większy popyt na produkty wytwarzane przez innowacyjne firmy. Minusem jest to, że cena zapłacona za knowhow nie zawsze jest adekwatna i nie zawsze równoważy skutki późniejszego nasilenia konkurencji.

Istotą tego zagadnienia jest na dobrą sprawę stworzenie równego, uczciwego pola gry. Problem jest tutaj dwojaki. Po pierwsze, konieczna jest odpowiednia równowaga pomiędzy innowatorami a naśladowcami, po drugie zaś, co do dziś zostało już obszernie udokumentowane, handel know-how bywa często wykorzystywany w celach uchylania się od podatków metodą cen transferowych.

Wreszcie, odnośnie do nowych globalnych firm superstar w branżach cyfrowych, a zwłaszcza tak zwanej wielkiej piątki (Alphabet, Apple, Amazon, Facebook i Microsoft), nasuwa się pięć istotnych obserwacji.

Po pierwsze, firmy superstar w branży cyfrowej przeważnie działają na zasadzie „Zwycięzca bierze wszystko”. Rynki cyfrowe cechują się występowaniem silnego efektu sieciowego, a przez to także brakiem skutecznej konkurencji, co z kolei przekłada się na wyjątkowo wysokie, ponadnormatywne zyski.

Po drugie, firmy superstar są silnym czynnikiem sprawczym spadku udziału pracy w wytworzeniu produktu. Van Reenen (2018, s. 21) zauważa, że „,wielkie firmy superstar będą dążyły do zapewnienia sobie wyższych marż zysku przy niższym udziale pracy w tworzeniu wartości dodanej”. To jednak nie dotyczy typowych firm amerykańskich, co wykazał autor (Sander i in., 2018). Dlatego, jak pisze dalej Van Reenen: „Tym, co wyjaśnia spadek zbiorczego udziału pracy i wzrost marż, jest realokacja w stronę firm większych i bardziej produktywnych". Inaczej mówiąc, rosnący udział firm superstar w krajowej puli wartości dodanej przesuwa dochody od siły roboczej w kierunku kapitału. Po trzecie, międzynarodowy ślad cyfrowych MNE różni się zasadniczo od śladu innych MNE, co dokumentuje UNCTAD (2017). Tabela 1 pokazuje, że tym pierwszym wystarcza ulokowanie za granicą jedynie ok. $40 \%$ łącznych aktywów własnych, aby skutecznie wejść na rynki zagraniczne i powiększyć udział sprzedaży zagranicznej w swojej sprzedaży łącznej na poziomie $70 \%$. Wynika z tego, że stosunek sprzedaży za granicę do ulokowanych za granicą aktywów jest jak 
ok. 1,8:1, czyli znacznie korzystniejszy niż stosunek 1:1 osiągany przez inne MNE. Stosunek ten jest szczególnie wysoki dla MNE będących dostawcami platform internetowych, rozwiązań cyfrowych oraz dla firm z branży informatycznej (oprogramowanie i usługi, urządzenia i komponenty do nich). W konsekwencji firmy te generują mniej inwestycji i niższe zatrudnienie w krajach, które obsługują swoimi produktami, w porównaniu do MNE z branż innych niż informatyka.

Tabela 1. Ślad międzynarodowy 100 czołowych przedsiębiorstw wielonarodowych (MNE, 2015)

\begin{tabular}{|c|c|c|c|}
\hline & MNE techniczne & $\begin{array}{c}\text { MNE } \\
\text { telekomunikacyjne }\end{array}$ & MNE inne \\
\hline $\begin{array}{l}\text { Udział aktywów } \\
\text { zagranicznych }\end{array}$ & $41 \%$ & $66 \%$ & $65 \%$ \\
\hline $\begin{array}{l}\text { Udział sprzedaży } \\
\text { zagranicznej }\end{array}$ & $73 \%$ & $57 \%$ & $64 \%$ \\
\hline \multirow{7}{*}{$\begin{array}{l}\text { Stosunek udziału } \\
\text { sprzedaży zagranicznej } \\
\text { do udziału aktywów } \\
\text { zagranicznych }\end{array}$} & 1.8 & 0.9 & 1.0 \\
\hline & z czego: & & z czego: \\
\hline & $\begin{array}{l}\text { platformy } \\
\text { internetowe: }\end{array}$ & & $\begin{array}{l}\text { przemysł } \\
\text { motoryzacyjny } \\
\text { i lotniczy: }\end{array}$ \\
\hline & $\begin{array}{l}\text { płatności cyfrowe } \\
\text { i inne rozwiązania } \\
\text { cyfrowe: }\end{array}$ & & \\
\hline & $\begin{array}{ll}\text { IT } & 1.8\end{array}$ & & \\
\hline & e-handel & & \\
\hline & treści cyfrowe & & \\
\hline
\end{tabular}

Źródło: na podstawie UNCTAD 2017, s. 170 i 171.

Po czwarte, MNE cyfrowe mają ściślejsze powiązania z macierzystymi krajami niż MNE z innych branż, a ponadto mają one swoje główne siedziby w zaledwie kilku krajach, z wyraźną koncentracją na terenie Stanów Zjednoczonych.

Po piąte, znaczna część uzyskanych za granicą dochodów, wyrażonych jako udział w łącznych dochodach przedsiębiorstwa, w wielu wypadkach nie jest ani odsyłana do kraju macierzystego, ani przeznaczana na finansowanie zdolności produkcyjnych za granicą w sposób porównywalny do tego, jak robią to MNE spoza branż technicznych (zob. tab. 2). W związku z tym UNCTAD (2017, 
s. 174) na podstawie analizy amerykańskich MNE wysuwa przypuszczenie, że: „głównym celem takiego postępowania wydaje się raczej zmniejszanie obciążeń podatkowych poprzez odraczanie (na czas nieokreślony) spłaty korekty podatku od repatriacji dochodów do Stanów Zjednoczonych. Co ciekawe, w roku 2015 MNE z branż technicznych obciążone były faktyczną stawką podatku dochodowego w wysokości 19\% - znacznie niższą od stawki obowiązującej inne amerykańskie MNE. Podane tu wzorce prawdopodobnie dotyczą także MNE z branży cyfrowej - można tak zakładać, biorąc pod uwagę ich cechy wspólne z przedsiębiorstwami o profilu technicznym"3.

Tabela 2. Dochody zagraniczne a faktyczna stawka podatkowa płaconego przez MNE ze Stanów Zjednoczonych należące do pierwszej setki UNCTAD (Top100, rok 2015)

\begin{tabular}{|l|c|c|c|}
\hline & $\begin{array}{c}\text { Udział lącznych } \\
\text { dochodów zagranicznych }\end{array}$ & $\begin{array}{c}\text { Stosunek nie przekazanych } \\
\text { dochodów zagranicznych } \\
\text { do środków trwałych }\end{array}$ & $\begin{array}{c}\text { Obowiązująca } \\
\text { stawka podatkowa }\end{array}$ \\
\hline $\begin{array}{l}\text { MNE } \\
\text { techniczne }\end{array}$ & $62 \%$ & 6 & $19 \%$ \\
\hline MNE inne & $23 \%$ & 1 & $27 \%$ \\
\hline
\end{tabular}

Źródło: na podstawie UNCTAD, 2017, s. 174.

Co wszystkie omówione tendencje mają ze sobą wspólnego? Po pierwsze, handel usługami, wiedzą i produktami cyfrowymi jest domeną poważnych wypaczeń. Po drugie, zjawiska te wyraźnie wskazują na potrzebę stworzenia lub utrzymania równego, uczciwego pola gry dla handlu usługami, know-how i danymi. Strategie doganiania, strategie build-up i strategie cyfrowe są zatem zasadniczym komponentem nowej polityki przemysłowej. Kluczowym pytaniem jest to, jak pogodzić te polityki z argumentem o równym i uczciwym polu gry. Wreszcie, po trzecie, wskazują one na konieczność znalezienia środków zaradczych przeciw strategiom uchylania się od podatków. W opublikowanym niedawno studium Tørsløv, Wier i Zucman (2018) szacują, że prawie 40\% zysków przedsiębiorstw wielonarodowych jest co roku przenoszonych do krajów o niskich podatkach. Przenoszenie zysków dokonywane jest głównie metodą cen transferowych i największe rozmiary przybiera wśród amerykańskich MNE. Z kolei straty z tytułu niezrealizowanych podatków szacowane są na najwyższym poziomie w krajach Unii Europejskiej oraz w krajach rozwijających się.

3 UNCTAD zastrzega, że dane te są ściśle związane z amerykańskim systemem podatkowym i mogą się zmienić po dokonaniu zamierzonych zmian w tym systemie. 


\subsection{Kraje szybkiego wzrostu i ich wielka konwergencja}

Udział w GŁW przyniósł niejednej wschodzącej gospodarce radykalną poprawę poziomu życia obywateli i wielką redukcję skali ubóstwa. Co więcej, szybki rozwój tych krajów zmienia globalną równowagę sił ekonomicznych, co prowadzi do kształtowania się świata wielobiegunowego lub przynajmniej trójbiegunowego (zob. rys. 3). O ile pod względem obecnego kapitału wyrażonego w dolarach amerykańskich Unia Europejska i Stany Zjednoczone nadal jeszcze wyprzedzają Chiny, o tyle w kategoriach siły nabywczej świat trójbiegunowy jest już faktem.

Rysunek 3. Udział w światowym PKB: UE, USA i Chiny, 1990-2016
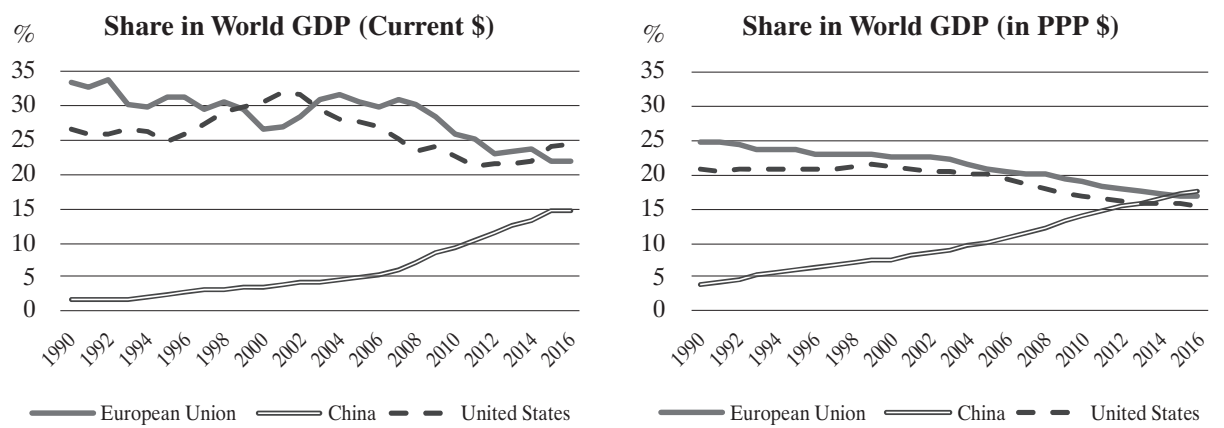

Źródło: obliczenia własne na podstawie danych Banku Światowego, World Development Indicators.

Czy „wielka konwergencja” będzie trwać dalej? I jakie będą jej następstwa dla globalnej geografii ekonomicznej? W tym kontekście rozważyć należy trzy kwestie: po pierwsze, czy znajdą się inne kraje zdolne pójść śladem modelu chińskiego; po drugie, czy w nowych technologiach kryją się nowe możliwości konwergencji dla krajów późno dołączających oraz, po trzecie, czy Chiny utrzymają tempo, które pozwala im doganiać kraje rozwinięte?

Ad 1. Czy inne kraje - w tym kontekście od razu nasuwają się Indie - okażą się następnym czynnikiem destabilizującym, po Chinach? Zacznijmy od tego, że takie kraje, jak Indie najprawdopodobniej będą się rozwijały bardziej stopniowo. Polityka przemysłowa „zza muru” w stylu chińskim nie będzie w nich równie skuteczna ani nawet równie dostępna, a to ze względu na przeszkody natury politycznej, zarówno krajowe, jak i wielostronne (WTO). Po drugie, nadzieje na relokację zadań z Chin do krajów sąsiednich o wciąż niższych kosztach produkcji mogą się nie ziścić, ponieważ odnośne zadania w Chinach mogą zostać zrobotyzowane, a nie relokowane. Na podobnej zasadzie - jak już wspomnieliśmy 
- robotyzacja ma potencjał nie tylko zastępowania relokacji, lecz nawet sprzyjania przenoszeniu działalności z powrotem do krajów, które uprzednio relokowały ją za granicę. Dlatego może się okazać, że model chiński przestanie dostarczać wzorca i recepty dla innych krajów „późno przystępujących” i nadganiających. Być może bardziej obiecującą metodą skorzystania na relokacjach pomiędzy krajami sąsiednimi będzie powiększanie skali rynku (również dzięki regionalnym umowom handlowym). Na przykład, dla spółek chińskich atrakcyjniejsze może być przenoszenie produkcji do Afryki niż do krajów ościennych, ze względu na to, że Afryka leży bliżej Europy i ma preferencyjny dostęp do rynku UE.

Ad 2. Nowe technologie, w szczególności te, których rozwój przyśpiesza dzięki redukcji kosztów komunikacji face-to-face, a więc takie jak teleobecność $\mathrm{i}$ telerobotyka - zgodnie z tezami Baldwina (2016). Te nowe technologie destabilizujące wzorzec mogą umożliwiać pracownikom w gospodarkach rozwijających się wykonywanie zadań o charakterze usługowym, takich jak zabiegi chirurgiczne, sterowanie robotami, konsultacje online przy użyciu technik VR i AR itd. W ten sposób kraje położone odlegle, w głębi dużych kontynentów, które w okresie ostatnich 30 lat nie korzystały z włączenia do GLW, mogą wkrótce znaleźć swoje nowe przewagi komparatywne w dziedzinie zadań wirtualnych. „Wielka konwergencja” może postępować dalej, nawet przy destabilizujących przemianach zachodzących w sektorach usług w gospodarkach rozwiniętych.

Ad 3. Co dalej z Chinami? Jeśli przyjrzymy się integracji handlowej na szczeblu regionalnym (rys. 4), zauważymy, że integracja handlowa wykazywała największą dynamikę w Azji, a w ramach tego kontynentu szczególnie w Chinach w pierwszej dekadzie XXI wieku. Działo się tak głównie z powodu wyjątkowo silnego udziału Chin w GLW. Obecnie wyraźnie widać, że Chiny tracą impet, przynajmniej z punktu widzenia PKB. Na to spowolnienie musiały wpłynąć trzy ważne przemiany: (1) rosnące znaczenie rynku krajowego Chin; (2) efekt „wyższych szczebli drabiny”, dzięki któremu obecnie wykonanie wielu zadań możliwe jest w samych Chinach, bez uzależnienia od importowanych półproduktów i komponentów, a zatem relokacja pracy w kierunku Chin, o czym mówiliśmy w części 2.2, oraz (3) czynnik „Made in China 2025”, czyli celowa strategia realizowana przez chiński rząd.

Ponadto, Chiny kładą silny nacisk na zdobycie przodującej pozycji technologicznej w dziedzinie odnawialnych źródeł energii oraz innych technologii i produktów przyjaznych dla środowiska, na przykład samochodów elektrycznych. Wreszcie, co wcale nie mniej ważne, chińskie podejście do kwestii technologii cyfrowych, animowane i nadzorowane przez państwo, może zapewnić branży cyfrowej w tym kraju przewagę konkurencyjną, zwłaszcza w zakresie AI, gdzie kluczem do rozwoju jest sama wielkość puli dostępnych i użytecznych danych. 
Rysunek 4. Handel towarami i usługami jako udział w PKB

(\%) w wybranych regionach 1960-2016

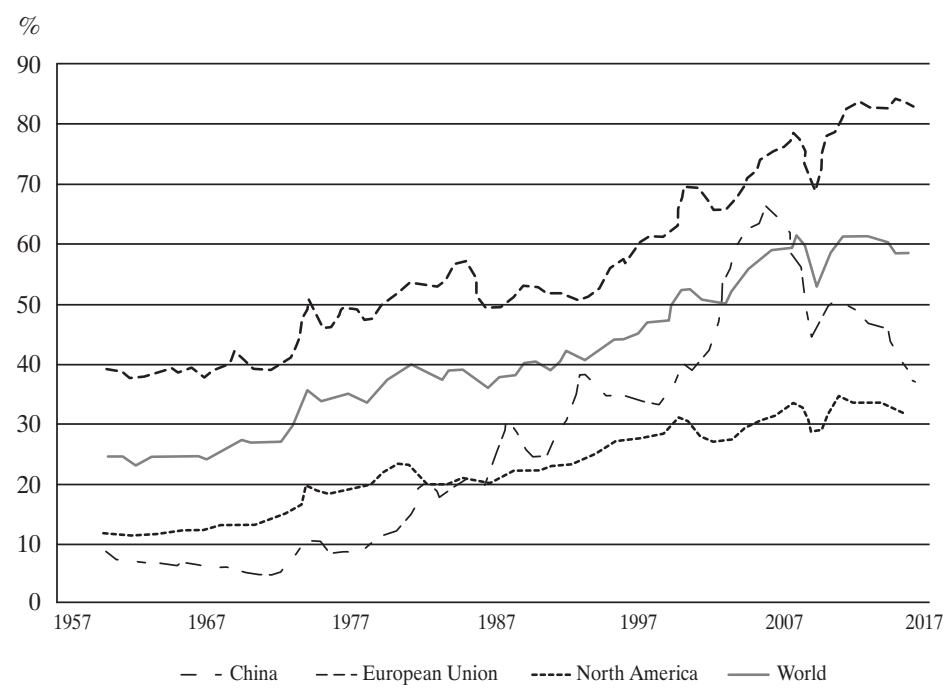

Źródło: World Bank, 2017. Pozyskano z: http://data.worldbank.org.

\subsection{Finanse globalne po światowym kryzysie finansowym}

Na pierwszy rzut oka, świadectwa empiryczne wskazują na globalną tendencję międzynarodowych finansów do okopania się na zajętych pozycjach, czyli ostrożności i oszczędzania. Bliższa analiza ujawnia dwie poważne zmiany: po pierwsze, taka redukcja kosztów w globalnej bankowości występuje w największym stopniu w Europie, a po drugie, wśród innych typów transgranicznych operacji finansowych jedyną kategorią aktywów, które rosły w stosunku do PKB w okresie po ŚKF, były BIZ. Tyle tylko, że rosły one z bardzo wyraźną koncentracją na tak zwanych centrach finansowych.

Odnośnie do globalnej bankowości, przede wszystkim zauważyć należy, że tendencję do oszczędności, okopywania się na zajętych pozycjach napędzają głównie banki europejskie. Trwałe następstwa wstrząsu, jakim był kryzys euro, nadal nieuzdrowiony system bankowy i nie w pełni ustabilizowana architektura strefy euro - w szczególności brak programu ubezpieczeniowego dla wkładów europejskich (EDIS) i ograniczony stopień dystrybucji obciążeń podatkowych - przyczyniły się do ogólnego spadku aktywności i wpływu europejskich banków, zwłaszcza w bankowości globalnej.

Dla pełnego zrozumienia przemian strukturalnych w globalnej bankowości ważne jest rozróżnienie dwóch postaci globalizacji w dziedzinie bankowości: 
$\mathrm{z}$ jednej strony międzynarodowego modelu biznesowego transgranicznej działalności kredytowo-depozytowej, z drugiej zaś międzynarodowego modelu tworzenia oddziałów zagranicznych poprzez BIZ (McCauley, 2011). W konsekwencji ŚKF wyhamował i zmalał głównie model międzynarodowy, przez co środek ciężkości bankowości globalnej przesunął się ku bankowości wielonarodowej. Wynika z tego, że obecna ekspozycja na zagrożenia zagraniczne jest w rzeczywistości bardziej „,skonsolidowana” niż sugeruje to bilans pozycji płatniczych ${ }^{4}$. Na podstawie skonsolidowanych statystyk bankowych z Banku Rozrachunków Międzynarodowych (mierzonych ze względu na narodowość banków), McCauley i in. (2017) stwierdzają, że w okresie 2007-2016 postawa oszczędności i ostrego cięcia kosztów widoczna była w całej strefie euro plus Wlk. Brytania i Szwajcaria, choć wyraźny wyjątek stanowiły banki hiszpańskie. Banki amerykańskie zasadniczo utrzymały swoje operacje międzynarodowe na poziomie nie zmienionym względem lat sprzed kryzysu, a jedynie przesunęły profil działalności bardziej w kierunku modelu bankowości wielonarodowej i nieco zwiększyły ekspozycję. Stąd też następujący wniosek w pracy McCauley i in. (2017, s. 8): „Jednakże banki z pozostałej [względem Europy] części świata nadal podążały szlakiem międzynarodowej integracji finansowej (...) - instytucje japońskie, amerykańskie, kanadyjskie, australijskie oraz z rynków wschodzących powiększały skalę swoich roszczeń zagranicznych na całym świecie, częściowo kompensując w ten sposób odwrót banków europejskich. W tym sensie tendencja ku deglobalizacji nie zyskała szerokiego oparcia”. Warto zauważyć, że rosnąca obecność gospodarek wschodzących w bankowości globalnej zapewne pozostaje niedoszacowana, jako że wiele $\mathrm{z}$ nich nie raportuje do Banku Rozrachunków Międzynarodowych lub - jak Chiny - czyni to dopiero od niedawna. W każdym razie pierwsze analizy wykazują, że banki z rynków wschodzących w szybkim tempie dołączają do globalnych rynków bankowych i że w największym stopniu dotyczy to banków chińskich.

Przechodząc do bezpośrednich inwestycji transgranicznych, odporności BIZ na kryzys finansowy nie należy traktować jako faktu zupełnie zaskakującego. Owszem, zostało dobrze udokumentowane, że w obrazie następstw kryzysu finansowego BIZ okazały się znacznie stabilniejszym źródłem finansowania zagranicznego niż strumienie bankowe lub portfelowe. Działo się tak w niemałym stopniu dlatego, że kryzysy finansowe mają tendencję zbiegać się z kryzysami

4 Raporty Banku Rozrachunków Międzynarodowych podają dane statystyczne na temat bankowości światowej na podstawie skonsolidowanej i lokalizacyjnej. W statystykach skonsolidowanych banki klasyfikuje się według ich narodowości, podczas gdy w statystykach lokalizacyjnych klasyfikuje się je według usytuowania siedziby, podobnie jak w statystykach bilansów płatniczych. 
walutowymi, a duża dewaluacja zwiększa konkurencyjność cenową gospodarki w kryzysie. Jednak w odniesieniu do globalnego kryzysu finansowego takie wyjaśnienie wydaje się niewystarczające. Lane i Milesi-Ferretti (2016) przedstawili gruntowne badanie na temat pokryzysowych tendencji ku integracji finansowej i wykryli ponad proporcjonalną rolę „,entrów finansowych” w BIZ - rolę, która po ŚKF jeszcze się zwiększyła. Wzrost skali BIZ w okresie pokryzysowym da się w dużej mierze wyjaśnić wzrostem pozycji BIZ w tych jurysdykcjach.

Czym są wspominane „centra finansowe” i o jakiego rodzaju BIZ mówimy? Lane i Milesi-Ferretti wybierają centra finansowe na podstawie ich nadzwyczaj wysokich wskaźników aktywów zewnętrznych oraz pasywów w stosunku do $\mathrm{PKB}$, w porównaniu z resztą świata. Oprócz dobrze znanych małych centrów finansowych (takich jak Bermudy lub Kajmany) do kategorii tej zalicza się także szereg gospodarek rozwiniętych, zwłaszcza Belgię, Hongkong, Irlandię, Luksemburg, Holandię, Singapur, Szwajcarię i Wielką Brytanię. W następstwie ŚKF w tej grupie krajów nastąpiło gwałtowne zmniejszenie skali transgranicznych operacji bankowych. Jednocześnie nastąpił drastyczny wzrost poziomu roszczeń i zobowiązań BIZ. Jakie są główne czynniki sprawcze tej dynamiki BIZ?

Zacznijmy od tego, że większe kraje z tej grupy są siedzibami wielkich przedsiębiorstw wielonarodowych. Dlatego kiedy poziom działalności w zakresie BIZ ogólnie wzrasta, rośnie również poziom BIZ w tych krajach. To jednak nie wystarcza do wyjaśnienia zarówno koncentracji BIZ w tych krajach, jak i ogromnych przesunięć BIZ w stronę centrów finansowych. Lane i MilesiFerretti (2017, s. 14) raportują: „Na koniec roku 2007 rezydenci centrów finansowych posiadali około 43 procent wszystkich zagranicznych roszczeń BIZ na świecie, natomiast BIZ w centrach finansowych stanowiły około 40 procent łącznej puli światowej BIZ. Do końca roku 2014 roszczenia BIZ ze strony centrów finansowych wzrosły do połowy łącznej puli globalnej, a zobowiązania do poziomu 44 procent”. Następnie badacze ci diagnozują dwa główne czynniki mogące wyjaśniać rozmiary niedawnej dynamiki pozycji BIZ w centrach finansowych.

Po pierwsze, autorzy ci wskazują na rosnące znaczenie tak zwanych „podmiotów specjalnego przeznaczenia". Są to podmioty prawne stworzone przez swoje spółki macierzyste usytuowane w innych jurysdykcjach. Celem istnienia takich podmiotów nie jest prowadzenie żadnej działalności produkcyjnej. Tworzone są one po to, by zdobywać i pomnażać kapitał albo utrzymywać aktywa i/lub pasywa. Wprawdzie dane na temat takich spółek nie są łatwo dostępne, jednak udokumentowano, że ponad $75 \%$ wszystkich roszczeń i zobowiązań BIZ w Holandii powiązana jest właśnie z takimi podmiotami. Dla Luksemburga odnośna wielkość jest jeszcze wyższa i przekracza $90 \%$. 
Po drugie, autorzy informują o rosnącej skłonności MNE do przenoszenia swoich siedzib do centrów finansowych. W sytuacji, w której przeniesiona zostaje tylko oficjalna siedziba, a nie zakłady produkcyjne, te ostatnie i tak zaliczają się do puli BIZ centrum finansowego. To właśnie w ten sposób znane raje podatkowe, takie jak Irlandia, zdołały zwiększyć skalę wykazanych roszczeń BIZ o 600 mld dolarów w latach 2007-2014, podnosząc roszczenia BIZ na poziom, który przekracza wielkość PKB Irlandii o czynnik wyższy niż 5 .

Podsumowując, globalne finanse po ŚKF charakteryzuje: 1) słabość bankowości europejskiej; 2) przesunięcie ku bankowości wielonarodowej; 3) postępująca globalizacja banków wywodzących się z gospodarek wschodzących, a zwłaszcza z Chin oraz 4) przesunięcie BIZ w stronę centrów finansowych, które następuje z przyczyn innych niż produkcja, co sugeruje, że „poważną rolę w tych zjawiskach odgrywa rosnąca złożoność struktury przedsiębiorczej wielkich korporacji międzynarodowych" (Lane i Milesi-Ferretti, 2017, s. 5).

\section{Globalizacja i populistyczny gniew}

Zarówno Europa, jak i Stany Zjednoczone doświadczają fali populizmu, który - zwłaszcza w wypadku USA - powoduje przywrócenie na arenie politycznej postaw protekcjonistycznych w dawnym, tradycyjnym wydaniu. Przemiany takie zagrażają wielostronnemu podejściu do zjawiska globalizacji, jakie dominuje w powojennych stosunkach międzynarodowych. Dla naszych rozważań istotą sprawy jest pytanie, w jakim stopniu źródła eksplozji populizmu da się powiązać przyczynowo z wstrząsami ekonomicznymi, których źródłem lub przekaźnikiem jest globalizacja.

W wydanym niedawno stadium historycznym Eichengreen (2018) rozważa: „Przytoczona tutaj historia sugeruje, że populizm uruchamiany jest przez połączenie niepewności ekonomicznej, zagrożenia dla tożsamości narodowej i niewrażliwego ustroju politycznego, ale że można go tłumić poprzez reformy gospodarcze i polityczne pozwalające rozwiać obawy niezadowolonych". Przytaczany badacz przechodzi następnie do zdefiniowania populizmu jako ruchu politycznego, który przejawia tendencje antyelitarne, autorytarne i natywistyczne (antyimigracyjne). Sformułowana w ten sposób definicja obejmuje zarówno populizm

Lane i Milesi-Ferretti (2017) przypominają, że w sytuacji, w której udziałowcy MNE relokowanych do kraju pochodzenia nie zmieniają się, to portfolio zobowiązań z tytułu akcji wzrasta o taką samą kwotę, w efekcie czego bilans na koncie kapitałowym pozostaje bez zmian. 
lewicowy, w którym dominuje element antyelitarny, jak i populizm prawicowy, skłonny za wszystkie trudności i problemy winić „obcych”.

W dyskusjach na temat ostatniej fali populizmu rozróżnić można dwa obozy intelektualne, które z całą stanowczością podają różne źródła i powody tego ruchu. Jeden z nich koncentruje się na roli ekonomii, a zwłaszcza na wzroście niepewności ekonomicznej, jaką sprowadza globalizacja, szczególnie w okresie po ŚKF, drugi natomiast skupia się bardziej na „reakcji i kontestacji kulturowej”. Historyczny punkt widzenia Eichengreena pozwala połączyć obie te perspektywy, ale zarazem kładzie wyraźny nacisk na odpowiedzialność „niewrażliwego ustroju politycznego".

Aby przeanalizować rolę globalizacji we wzbudzeniu fali populizmu, w pierwszej kolejności zajęto się efektem dystrybucyjnym globalizacji, by następnie omówić zauważalną w ostatnim okresie niewrażliwość, czyli nieczułość ustrojów politycznych i na koniec ocenić związek przyczynowy pomiędzy globalizacją i populizmem.

\subsection{Globalizacja i niezadowoleni}

Globalizacja, a w szczególności wstrząs chiński, mają zarówno aspekty pozytywne, jak i negatywne. Oprócz typowych korzyści z wymiany handlowej, to znaczy niższych cen towarów, w których wykorzystano tańsze surowce pochodzące zza granicy, uczestnictwo w GŁW może wywierać korzystny wpływ na produktywność siły roboczej, podnosząc tym samym międzynarodową konkurencyjność firm krajowych. Według Constantinescu i in. (2017), wzrost udziału w GLW o $10 \%$ podnosi średnią produktywność siły roboczej o $1,7 \%$.

Jednakże zwiększona globalizacja łańcuchów wartości wymaga również dokonania w krajach rozwiniętych restrukturyzacji na wielką skalę i pociagga za sobą problemy tych, którzy tracą miejsca pracy wskutek relokacji zadań do odległych krajów. Obecnie jest dobrze udokumentowane, że od lat dziewięćdziesiątych XX wieku globalny rozkład dochodów uległ kolosalnym zmianom. Zebrane świadectwa wskazują na dwa główne czynniki sprawcze rozbicia dawnych wzorców dystrybucji. Pierwszym są poważne skutki redystrybucyjne zarówno pomiędzy poszczególnymi krajami, jak i wewnątrz nich w kategoriach warstw dochodu. Drugim - wyraźny spadek udziału dochodów z pracy względem udziału dochodów odpływających do kapitału.

Skutki redystrybucyjne są obecnie spektakularnie uwidocznione w postaci głośnej „krzywej słonia” (Elephant Curve; Lakner i Milavonic, 2013). Wykres ten ilustruje wzrost dochodu na głowę wyrażony w percentylach dystrybucji dochodu globalnego, od 5\% najuboższych krajów po lewej stronie do 1\% naj- 
bogatszych po prawej. W okresie 1988-2008 dochody per capita wzrosły średnio o około $24 \%$ (czyli ok. 1,1\% rocznie). Widać wyraźnie, że 5\% najuboższych krajów nie w pełni korzystało z tego wzrostu, natomiast warstwy średniego dochodu w gospodarkach wschodzących skorzystały z niego wydatnie, czego efektem było wywindowanie dużych grup ludności ponad poziom ubóstwa. Nierówności pomiędzy krajami zmniejszały się - Baldwin (2016) nazwał ten proces „wielką konwergencją”. W krajach rozwiniętych głównym powodem do obaw są przemiany zachodzące w górnych $20 \%$ percentyli: „krzywa słonia” wykazuje niemalże stagnację dochodów na głowę dla grupy 80-90 percentylu oraz słabe wyniki niemal wszystkich z wyjątkiem szczytowego $1 \%$. Zjawisko to często bywa interpretowane jako dowód na zapaść klasy średniej w krajach rozwiniętych, której towarzyszy kolosalny wzrost dochodów gromadzonych przez niezwykle wąską elitę. Biorąc pod uwagę, że przemiany te nastąpiły równocześnie $\mathrm{z}$ wielkim rozwojem globalizacji, trudno się dziwić, że dostrzega się powiązanie pomiędzy utratą dobrze płatnych miejsc pracy (w produkcji) w krajach zamożnych a gwałtownym rozwojem konkurencji w gospodarkach wschodzących.

Jednakże zbieżność tego zjawiska $z$ hiperglobalizacją i rozwojem GLW nie ma charakteru związku przyczynowego. Jak już mówiono, odpowiedzialność za utratę miejsc pracy i dochodów (w szczególności przez gorzej wykwalifikowanych pracowników w krajach rozwiniętych) w dużej mierze ponoszą nowe technologie i powstanie cyfrowych firm superstar. Niedawne badanie MFW (IMF, 2017) analizuje przyczyny powszechnego spadku udziału pracy w dochodach. Jego autorzy raportują, że w krajach rozwiniętych udział pracy w dochodach zmniejszył się w latach 1993-2014 o prawie cztery punkty procentowe. Spadek ten przypisywany jest $\mathrm{w}$ około połowie postępom techniki, natomiast udział w GLW oraz integracja finansowa odegrały tu znacznie mniejszą rolę. W tym samym studium prześwietlono także wpływ przemian na ludzi ze względu na poziom ich kwalifikacji. Analiza ta ujawnia silne efekty redystrybucyjne zachodzące w całym spektrum: wysoko wykwalifikowani zyskują więcej, a nisko wykwalifikowani tracą więcej, podczas gdy sytuacja grup pośrednich zmienia się mniej wyraźnie. O ile w odniesieniu do grup wysoko i nisko wykwalifikowanych procesy te można by jedynie w małym stopniu tłumaczyć wpływem technologii lub uczestnictwa w GLW, to w wypadku grupy pracowników o średnich kwa-

6 Przeciwnie dzieje się na rynkach wschodzących, gdzie powodem spadku udziału pracy w dochodach o prawie 6 pkt procentowych jest w decydującym stopniu uczestnictwo w GLW, podczas, gdy nowe technologie odgrywają pod tym względem małą rolę. Trzeba jednak zauważyć, że mówimy tutaj o udziale w dochodach, a nie o całkowitej wielkości dochodów. Ponieważ w wielu gospodarkach wschodzących, a zwłaszcza w Chinach, dochody rosły gwałtownie, dochody z pracy w sumie nadal się zwiększają, tyle tylko, że nie tak spektakularnie jak dochody z kapitału. 
lifikacjach z pewnością jest inaczej. Ci ludzie stracili poważną część swojego udziału w dochodach właśnie z powodu postępu technicznego i uczestnictwa w GLW. Co więcej, w krajach rozwiniętych technologia była jeszcze ważniejszym czynnikiem w „drążeniu i drenowaniu klasy średniej”. Zgodnie z wnioskami wcześniej przywołanego studium Acemoglu i Restrepo (2018), efekt taki da się łatwo pogodzić z efektami automatyzacji zadań, co przy okazji wskazuje na poważną rolę robotyzacji.

$\mathrm{Z}$ tych zjawisk można wnioskować, że wynikający z globalizacji rozdział zysków wśród pracowników w świecie uprzemysłowionym zmienia się i w coraz większym stopniu preferuje osoby wysoko wykwalifikowane. Ponadto, w miarę, jak rośnie udział kapitału w dochodach, beneficjentem niezmiernych korzyści stają się globalne korporacje.

Opisywana sytuacja zaostrzyła się po tym, jak ŚKF zepchnął w szczególności kraje rozwinięte w długotrwałą recesję, która dotknęła Stany Zjednoczone i Europę. W Europie, a zwłaszcza w strefie euro, sytuację dodatkowo pogorszył kryzys strefy euro, który nastąpił wkrótce później. O ile w gospodarce wysokociśnieniowej skutki uboczne przemian strukturalnych bywają znacznie łatwiej amortyzowane przez wzrost możliwości zatrudnienia, to taki podwójny wstrząs globalizacji i kryzysów finansowych wyraźnie przekłada się na głębokie i trwałe następstwa w zakresie dochodów i bezpieczeństwa ekonomicznego dużych grup ludności.

Podsumowując, określiliśmy trzy najważniejsze czynniki sprawcze niepewności ekonomicznej: uczestnictwo w GŁW i relokację miejsc pracy; postęp techniczny wraz z robotyzacją i cyfryzacją oraz kryzysy finansowe.

\subsection{Wrażliwość i zdolności reagowania systemów politycznych}

Jeśli historia może być tutaj wskazówką, fali populizmu można spodziewać się wtedy, gdy ustrój polityczny jest nieczuły i niereagujący (Eichengreen, 2018), a w ujęciu pozytywnym, populizm można kontrolować poprzez punktualne, właściwe i proporcjonalne reakcje polityczne. Skoro tak, to co wstrzymuje takie reakcje?

Po piewsze, klasyczny argument ekonomistów, mówiący, że przegranych na globalizacji można wynagrodzić, bo pozwolą na to łączne korzyści z wymiany handlowej, jest zasadniczo słuszny, lecz niestety wyłącznie jako możliwość teoretyczna. W praktyce ostatnich dziesięcioleci globalne korporacje skwapliwie wykorzystywały sposobności uchylania się od płacenia podatków, jakie otwiera zglobalizowany świat inwestycji, a wygrani na globalizacji głosowali i lobbowali raczej na rzecz obniżania podatków niż na rzecz redystrybucji rosnących docho- 
dów, mogącej przywrócić przegranym utracone możliwości pracy zarobkowej. Jednocześnie zaś kryzys finansowy oraz wielka recesja, która po nim nastąpiła, radykalnie pogorszyły szanse przegranych procesu globalizacji na znalezienie nowego zatrudnienia.

Po drugie, reakcje polityczne zależą od woli politycznej - od decyzji i wyborów. Oczywiście, niektóre kultury są mniej skłonne do amortyzowania skutków przemian strukturalnych narzędziami polityki socjalnej i polityki zatrudnienia, a inne bardziej. W tym kontekście wystarczy pomyśleć o Stanach Zjednoczonych w porównaniu z Europą, a w jej ramach szczególnie o krajach skandynawskich $\mathrm{z}$ ich hojnymi systemami podtrzymania dobrobytu i zabezpieczenia społecznego.

Po trzecie, adekwatne reakcje polityczne mogą być też ograniczane przez wielkość dostępnych zasobów w stosunku do skali nietypowego wstrząsu ekonomicznego. Wstrząs globalizacyjny może być tak wielki, że środki przeznaczane na „rekompensaty dla przegranych” bywają ograniczone wysokością wpływów podatkowych, np. skalą dochodów, których fiskus nie zrealizował $\mathrm{z}$ winy skutecznych strategii uchylania się od podatków przez wielkie korporacje wielonarodowe. Albo odwrotnie, wstrząsy wywołane przez kryzys finansowy mogą być tak dramatyczne - przykładem ŚKF - że nawet interwencje polityczne na dużą skalę nie wystarczają i nie chronią przed głęboką i długotrwałą recesją.

Po czwarte, pewne ramy instytucjonalne, takie jak przepisy podatkowe ograniczające deficyty fiskalne, mogą stanowić „polityczny kaftan bezpieczeństwa". Tak właśnie dzieje się w widoczny sposób w krajach strefy euro. Kraje członkowskie UGW (Unii Gospodarczej i Walutowej) nie są w stanie reagować na niespodziewany i nieregularny wstrząs ani instrumentami krajowej polityki monetarnej, ani dewaluacją waluty ${ }^{7}$. Co gorsza, polityka fiskalna w wielu państwach członkowskich została poważnie skrępowana przepisami skarbowymi Europejskiego Paktu Stabilności i Wzrostu.

Wreszcie, pewną rolę może także odgrywać ideologia i brak solidarności międzynarodowej. W strefie euro twórcy polityki postawili w największym stopniu na liberalizację rynku pracy i w ten sposób usiłowali wytłumić wstrząsy wywołane przez globalizację i kryzys finansowy. Podczas kryzysu strefy euro brak mechanizmów transgranicznych transferów fiskalnych oraz niechęć krajów-wierzycieli do przyjmowania z zagranicy odpowiedniej porcji obciążenia ukierunkowały pakiety ratunkowe w stronę polityki oszczędności i wyrzeczeń w połączeniu z reformami strukturalnymi obliczonymi na wywołanie korekt wynagrodzeń

7 Ponieważ kryzys finansowy roku 2008 był wstrząsem doświadczanym wspólnie przez wszystkie kraje członkowskie, ten argument miał zapewne mniejsze znaczenie (chociaż adekwatność ówczesnych reakcji ze strony polityki monetarnej EBC jest dyskusyjna) niż podczas kryzysu w strefie euro, który zaczął się w roku 2010 i uderzył w kraje członkowskie asymetrycznie. 
i cen w dół. Większość obserwatorów z kręgów akademickich zgadza się, że taka reakcja polityczna poważne pogłębiła i przedłużyła kryzys w wielu dotkniętych kryzysem krajach Europy, szczególnie na południu kontynentu.

\subsection{Globalizacja, kryzys finansowy i nasilenie populizmu}

Podsumowując to wszystko, możemy udokumentować narastającą niepewność ekonomiczną w wielu krajach rozwiniętych, odczuwaną w największej mierze przez osoby o niskich kwalifikacjach, ale coraz wyraźniej zagrażającą także klasie średniej. Natomiast trudno byłoby wskazać jedną konkretną przyczynę lub choćby głównego winnego tego stanu. Społeczeństwa stojące w obliczu złożonych zagrożeń dla swojego poziomu życia i bezpieczeństwa ekonomicznego widzą niewrażliwość polityki i szukają kozłów ofiarnych. Zależnie od zaplecza ideologicznego, edukacyjnego i kulturalnego ludzi, jako winnych wskazuje się różne grupy: populiści prawicowi na ogół obwiniają „obcych” - imigrantów, konkurencję zagraniczną itd., podczas gdy populiści z lewicy oskarżają „elity”. Oczywiście populistyczni „przedsiębiorcy polityczni” objaśniają świat w sposób uproszczony i podają niezadowolonym proste recepty na to, jak ulżyć ich doli.

Co prawda pewne świadectwa wskazują na słuszność hipotezy kulturowej, szczególnie w zakresie ścierania się populizmu lewicowego i prawicowego, jednak przeprowadzone ostatnio gruntowne badanie wykryło, że głównym źródłem narastania fali populizmu jest nasilona postrzegana i uświadamiana niepewność ekonomiczna. W skupionym na sprawach europejskim studium Guiso i in. (2018) badają, w jaki sposób rozkład głosów oddanych na partie populistyczne w różnych regionach Europy odzwierciedla reakcję na: 1) „wstrząs globalizacji” (czyli „efekt Chin”) oraz 2) na europejski kryzys finansowy lat 2008-2013. Europa stanowi naturalny poligon doświadczalny do rozpoznawania źródeł populizmu, ponieważ „wstrząs chiński” wywarł inne skutki w Europie Zachodniej, inne zaś - w Europie Wschodniej. Na zachodzie kontynentu dominował odpływ zadań i miejsc pracy za granicę, natomiast kraje Europy Wschodniej były częściowo również odbiorcą zadań i miejsc pracy relokowanych z zachodu. $\mathrm{Z}$ drugiej strony, kraje członkowskie strefy euro skrępowane były ciasnym politycznym kaftanem bezpieczeństwa (zależnym od względnej kondycji ekonomicznej i fiskalnej danego kraju w chwili nadejścia nieregularnych wstrząsów), podczas gdy kraje nie członkowskie były wolne od takich ograniczeń.

Guiso i in. (2018) wykorzystują tę właśnie perspektywę, aby pokazać, że wstrząs globalizacji, który dotknął regiony Europy Wschodniej najbardziej narażone na globalizację, nie sprzyjał pojawianiu się ani wzmacnianiu głosów 
populistycznych. W Europie Zachodniej, przeciwnie, wstrząs globalizacji wywołał wielkie pomnożenie głosów oddanych na partie populistyczne. Świadectwo takie sugeruje, że w kontekście głosowania na populistów istotnym czynnikiem jest podział na wygranych i przegranych globalizacji. Co więcej, autorzy ci wskazują również, że w tych krajach Europy Zachodniej, które należą do strefy euro, efekt kaftana bezpieczeństwa wyjaśnia aż w trzech czwartych zwiększone powodzenie wyborcze partii populistycznych w porównaniu z krajami spoza strefy euro. Inaczej mówiąc, im bardziej ograniczona swoboda państw w zakresie podejmowania środków naprawczych po wstrząsach globalizacji i kryzysach finansowych, tym większe poparcie polityczne dla partii populistycznych. Dlatego Guiso i in. (2018, s. 4-5) twierdzą, że „Bunt kulturalny przeciw globalizacji, tradycyjnej polityce i instytucjom, a także przeciw imigracji i automatyzacji, nie może być zjawiskiem egzogenicznym, lecz napędzany jest niezadowoleniem i lękiem o podłożu ekonomicznym".

Na podobnej zasadzie, w studium historycznym na temat wpływu kryzysów finansowych na zachowania wyborców i sukcesy politycznych ekstremistów w długim okresie od roku 1870 do 2014, Funke i in. (2015) dowodzą, że recesje wywołane kryzysami finansowymi zwiększają pulę głosów oddawanych na partie skrajnie prawicowe o około $30 \%$. Z drugiej strony, badacze ci nie byli w stanie wykazać analogicznego wpływu zwyczajnych recesji gospodarczych ani innych wstrząsów makroekonomicznych. Autorzy wnioskują z tego, że opinia publiczna ma większą tendencję uznawać, że to kryzysy finansowe, a nie „zwyczajne” kryzysy są konsekwencją błędów i zaniedbań politycznych, o które obwiniać należy tradycyjne elity polityczne. Co więcej, badacze ci podkreślają fakt, że pokonywanie kryzysów finansowych często wymaga niepopularnych akcji ratunkowych i oddłużeniowych na rzecz przedsiębiorstw zagrożonych upadłością, co opinia publiczna uznaje za nagradzanie tych, którzy w największym stopniu przyczynili się do wywołania kryzysu. Wreszcie, reperkusje społeczne kryzysu finansowego na ogół sięgają głębiej i trwają dłużej niż w wypadku zwyczajnych kryzysów.

Podsumowując, wymieńmy raz jeszcze co stanowiło podłoże, na którym populiści z łatwością budowali swoje autorytarne, upraszczające diagnozy i recepty, chętniej oskarżając kozły ofiarne niż podejmując i usiłując rozwiązać prawdziwe problemy. Na podłoże to składały się: pęknięcia społeczne zlekceważone przez politykę państwa, rosnące obawy wywołane wstrząsami globalizacji i kryzysów finansowych, niestabilny i przez to podatny na kryzysy system globalny, regionalny i finansowy, a równocześnie - o czym na porządku dziennym informowały media - gigantyczne fortuny i zyski jednego procenta najbogatszych oraz korporacji, skutecznie uchylających się od płacenia podatków. 


\section{Opcje polityczne w Europie w ramach nowej ekonomii globalnej}

Wśród czynników kształtujących przyszłość Europy z pewnością znajdą się następstwa nowego wcielenia globalizacji i polityczne reakcje na nią. Wnioski z zawartych powyżej rozważań przekonują, że globalizacja nie jest procesem zdolnym samoczynnie podtrzymywać swój rozwój. Gdyby nie zarządzać globalizacją i jej konsekwencjami dystrybucyjnymi, proces ten przejawi tendencje do podważania własnych podstaw, czyli wiary w wolne, otwarte rynki, społeczeństwa i granice.

Dla Europy otwarte rynki zarówno w ramach UE, jak i wobec reszty świata, są niezbędnym warunkiem jej modelu sukcesu ekonomicznego. Dlatego zapewnienie trwałości globalizacji leży w żywotnym i długofalowym interesie Europy. Aby było to możliwe, konieczne jest spełnienie szeregu warunków, od zachowania wrażliwości i uwagi społecznej, po podjęcie zdecydowanych działań politycznych. Potencjalna lista zadań do wykonania jest długa i można ją znaleźć na stronach internetowych wielu inicjatyw, zespołów eksperckich i doradczych oraz dyrekcji unijnych. Obejmuje ona i obraca się wokół takich zagadnień, jak cyfryzacja, populizm, nierówności, konkurencyjność i inne. Jednak zestawienie listy to nie wszystko; warunkiem adekwatnej reakcji politycznej jest rozwiązanie trudnej kwestii rozdysponowania zadań. Na jakim szczeblu winny one być realizowane? Na krajowym, europejskim czy globalnym? W dalszej części niniejszego studium najpierw omówione zostaną najpilniejsze kwestie polityczne, a w dalszej kolejności problem rządów.

\subsection{Obszary reakcji politycznych}

W swoim wystąpieniu na Sympozjum Polityki Ekonomicznej Banku Rezerwy Federalnej Kansas City w Jackson Hole, w roku 2017, Prezydent EBC Mario Draghi stwierdzit: „Ludzie niepokoją się o to, czy otwartość jest uczciwa, czy jest bezpieczna i czy jest sprawiedliwa”.

By rozważyć na początek kwestię sprawiedliwości, ekonomiści handlu w zasadzie zgadzają się co do tego, że po otwarciu się na wymianę handlową w społeczeństwie rysuje się podział na wygranych i przegranych. Jako, że korzyści netto z handlu są znaczne i stanowią silny argument, ekonomiści wolą proponować rekompensowanie przegranych niż protekcjonizm. Problem $\mathrm{z}$ rekompensowaniem polega na tym, że w większości wypadków jest to działanie albo niewystarczające, albo zostaje ono w ogóle zaniechane. Konsekwencje dystrybucyjne da się łagodzić poprzez wynagradzanie przegranych metodami systemów opieki i zabezpieczenia społecznego, redystrybucją ze środków pań- 
stwowego systemu podatkowego oraz działaniami na rzecz przekwalifikowania siły roboczej.

Wraz z rozpowszechnieniem się GŁW stało się oczywiste, że konkurencja zmieniła swoją postać. Obecnie zachodzi ona nie tyle pomiędzy towarami i firmami z poszczególnych krajów, ile pomiędzy poszczególnymi pracownikami na globalnym rynku pracy i toczy się o miejsca pracy (Baldwin, 2006). Relokacja zadań za granicę może nastąpić w każdej chwili. Głównymi cechami podzielonej globalnej produkcji stały się nagłość i nieprzewidywalność. Ponadto, postępująca robotyzacja zadań oraz ich przenoszenie za granicę, a następnie sprowadzanie z powrotem do kraju powodują gwałtowną zmianę typu pożądanych kwalifikacji w kierunku umiejętności pracy zespołowej, umiejętności cyfrowych, przystosowawczych, elastyczności oraz umiejętności uczenia się. Co więcej, nadejście cyfrowej łączności indywidualnej (face-to-face) będzie coraz bardziej zagrażać miejscom pracy osób wysoko wykwalifikowanych.

W związku z tym tradycyjny protekcjonizm chroniący konkretne branże gospodarki może okazać się niewystarczającym narzędziem, aby stawić czoła cyfryzacji i nowej globalizacji. Preferowaną reakcją powinno być raczej skupienie się na edukacji, uczeniu umiejętności uczenia się i kształtowaniu zdolności przystosowawczych. Obecnie kluczem do skutecznej polityki (re-)dystrybucji nie jest, jak dawniej, ochrona branż, lecz ochrona ludzi (Baldwin, 2006). Oprócz tego, jako że cyfryzacja i globalizacja przyczyniają się do zmniejszania udziału globalnych dochodów trafiających do pracowników, a więc pośrednio nasilają nierówności dochodowe w wielu krajach, kolejną pilną kwestią polityczną staje się również znalezienie środków zaradczych na te nierówności, co wykracza poza ochronę przegranych na globalizacji.

Jednakże, jak pokazują powyższe rozważania, wpływu globalizacji na sprawiedliwość społeczną często nie da się odróżnić od wpływu nowych technologii, ponieważ z punktu widzenia osoby zwolnionej nie ma żadnej różnicy pomiędzy tym czy jej miejsce pracy przeją robot, czy zrobili to pracownicy zagraniczni. W obydwu wypadkach doszło do utraty miejsca pracy i do okresowej, a być może nawet trwałej utraty dochodów. Natomiast tym, co odróżnia przemiany w handlu od innych przemian strukturalnych jest zagadnienie uczciwości. Rodrik (2017) twierdzi, że sama polityka redystrybucji nie wystarcza, aby stawić czoła wyzwaniom globalizacji: „Prowadzi nas to do innego społecznego i politycznego zarzutu wobec handlu: mianowicie, że handel narusza normy zakorzenione w naszych rozwiązaniach instytucjonalnych. Sugeruję tym samym, że handel może podkopywać interesy społeczne właściwe $\mathrm{i}$ istotne dla narodu, uznane i gwarantowane w jego prawie i przepisach. (...) Handel jest nie tylko stosunkiem rynkowym - jest również ingerencją w krajowe instytucje i narzę- 
dziem ich przekształcania ze szkodą dla niektórych grup”. W związku z tym Rodrik uważa za uzasadnione reagowanie na „dumping społeczny” (czyli np. sytuacje, w których konkurenci zagraniczni podcinają płace przez naruszanie praw pracowniczych swojej siły roboczej, ograniczając płace metodami politycznymi lub wykorzystując pracę przymusową itd.) w sposób analogiczny do tego, jak państwa reagują na zwyczajny „dumping cenowy”. Propozycja Rodrika sprowadza się zasadniczo do chronienia narodowej umowy społecznej instrumentami państwowej polityki antydumpingowej, a nie poprzez reakcje wielostronne.

Przeciwne stanowisko zajmuje Mario Draghi (2017), który opowiada się za reakcją wielonarodową na rzecz rozwiązania kwestii uczciwości (i jednocześnie bezpieczeństwa): „...współpraca wielostronna, prowadząca do konwergencji przepisów prawnych, stanowi warunek wstępny dla zaradzenia głębokim przyczynom tych niedomagań. Wykażę to, odwołując się do doświadczeń zarządzania otwartością w Unii Europejskiej. Odnośnie uczciwości, sprawa jest oczywista: ujednolicenie przepisów stanowi najsilniejszą gwarancję, że na całym wspólnym rynku europejskim zapewnione będzie równe pole gry. Właśnie z tego powodu po otwarciu granic wewnętrznych w Europie nastąpiło równoległe i jednoczesne wzmocnienie wspólnych, ponadnarodowych organów ustawodawczych i egzekucyjnych. Podobnie, tym, co sprawiło, że Jednolity Rynek przetrwał rozmaite kryzysy finansowe i związane $\mathrm{z}$ ochroną konsumentów była jego zdolność do przywracania bezpieczeństwa poprzez dostosowywanie przepisów wykonawczych i środków egzekucyjnych na całym obszarze”.

Niemniej, europejska konwergencja w zakresie przepisów prawnych nie jest tylko atrakcyjnym narzędziem tworzenia w Europie równego i uczciwego pola gry. Jako przykład weźmy ostatnie doświadczenia z unijnym rozporządzeniem RODO. „The Economist” (22.09.2018, s. 13) stwierdza, że „zasady RODO są obecnie wykorzystywane jako wzorcowe praktyki w zakresie danych na wielu rynkach pozaeuropejskich". Unia Europejska ze swoim ogromnym wspólnym rynkiem jest w stanie użyć swoich kompetencji regulacyjnych do zwiększenia w oczach swoich obywateli legitymacji i uczciwości nie tylko integracji europejskiej, lecz także globalizacji. Wobec nowego oblicza globalnej gospodarki najważniejsze dziedziny skutecznego wpływania lub choćby przyczyniania się do realizacji wzorcowych praktyk w sferze regulacyjnej w skali globalnej z pewnością obejmują przeciwdziałanie uchylaniu się od podatków i korporacyjnemu „wyścigowi po najniższe podatki”, gwarancje praw pracowniczych, zapewnienie stabilności finansowej oraz inne wielostronne inicjatywy na rzecz regulacji globalnych finansów, handlu, inwestycji, know-how i obrotu danymi. Europa, która solidnie zajmie się tymi dziedzinami i naprawi je zarówno w ramach UE, jak i na całym kontynencie, ustanawiając tym samym globalny wzorzec dbałości o uczci- 
wość w stosunkach wielostronnych, może przyczynić się znacząco do tego, że globalizacja stanie się nie tylko uczciwa, bezpieczna i sprawiedliwa, lecz także trwała i długofalowo akceptowalna.

Europa, która za priorytet w zakresie sprawiedliwości uzna ludzi i poważnie zajmie się kwestiami uczciwości, tak na kontynencie, jak i na szczeblu międzynarodowym, podejmując kluczowe kwestie, które ludzi drażnią i niepokoją, osiągnie widoczne efekty z pewnością dostrzegalne dla europejskich wyborców.

\subsection{Rządy europejskie}

\subsubsection{Europejski trylemat polityczny}

Na jakim szczeblu winny być podejmowane decyzje? Co powinno pozostać w gestii państwa narodowego, a co należy przekazać na szczebel ponadnarodowy - delegując czy to do Unii Europejskiej, czy do globalnych instytucji wielonarodowych, takich jak WTO? Rodrik (2011) jest zdania, że w tym kontekście pojawia się „trylemat globalizacji”, który zmusza twórców polityki do dokonania wyboru pomiędzy hiperglobalizacją, podejmowaniem decyzji na szczeblu narodowym i polityką demokratyczną (zob. rys. 5).

Rysunek 5. Trylemat globalizacji Rodrika (w którym wybrać można tylko dwa rozwiązania)

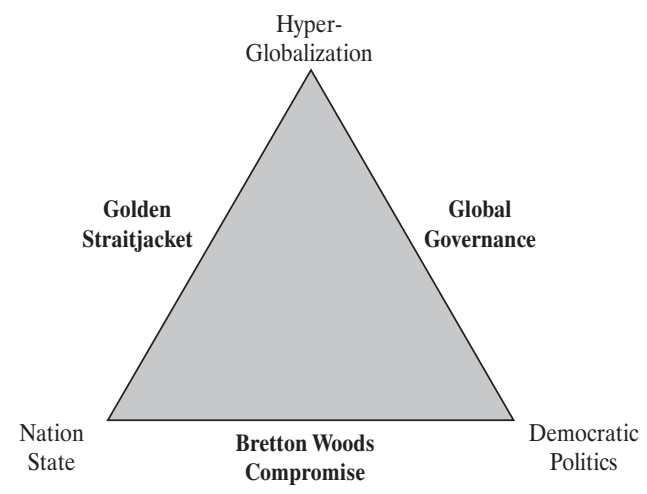

Źródło: diagram na podstawie: Rodrik, 2011, s. 201.

Argument podstawowy mówi, że nadmierna globalizacja potrzebuje globalnych rządów opartych na demokratycznej legitymacji. Alternatywnie, jeżeli państwa nie są skłonne odstąpić części swojej suwerenności przez jej przekazanie instytucjom ponadnarodowym, stracą demokratyczną kontrolę w obliczu hiperglobalizacji, a wtedy znajdą się praktycznie na łasce „mechanizmów” ryn- 
kowych. Przykładowo, parytet złota wymuszał stosowanie w razie konieczności automatycznych korekt. Doświadczenia z początku XX w. z automatycznymi (deflacyjnymi) korektami były katastrofalne, jako że młode demokracje i rosnące w siłę ruchy robotnicze nie chciały zaakceptować niezwykle wysokiego poziomu bezrobocia jako narzędzia pobudzania deflacji płac. Podobnie, próby zastosowania deflacji płac i cen w celu przywrócenia konkurencyjności w kilku krajach w okresie kryzysu strefy euro wywołały masowe bezrobocie i zagroziły tkance społecznej w krajach dotkniętych kryzysem. Z kolei - jak sugeruje omawiany trylemat - zachowanie kompetencji decyzyjnych na szczeblu państwa narodowego wymaga ograniczania hiperglobalizacji.

Czy Unia Europejska, jawnie dążąca do ujednolicenia norm prawnych na całym swoim obszarze, nie jest lepiej przygotowana do realizacji tych zadań w kontekście europejskiej integracji ekonomicznej? Benoît Cœuré (2017), członek zarządu Europejskiego Banku Centralnego (EBC), następująco komentuje trylemat Rodrika: „...doświadczenia europejskie pokazują, że te kompromisy dadzą się zrealizować. Możliwy jest wariant globalizacji oparty na szczątkowym szkielecie przepisów międzynarodowych szczebla wspólnotowego, który pozostawi swobodę manewru rządom krajowym. Zasadę subsydiarności, silnie zakorzenioną w postanowieniach Traktatu o Unii Europejskiej, można faktycznie interpretować jako regionalną próbę rozwiązania trylematu Rodrika. Jej celem jest zapewnienie, aby decyzje w jak największym stopniu podejmowane były na korzyść obywatela i aby działania na szczeblu europejskim inicjowane były tylko wtedy, kiedy danych celów nie da się zadowalająco osiągnąć na szczeblu krajowym, regionalnym lub nawet lokalnym".

$\mathrm{Z}$ niniejszych rozważań wynika konieczność rozwiązania dwóch istotnych problemów. Po pierwsze, trylemat Rodrika może być obecny w niektórych, ale nie wszystkich aspektach „globalizacji”. Dlatego ważne jest ustalenie, na jakim szczeblu najsłuszniej jest podejmować dane decyzje, uzależniając to od konkretnych kwestii, których decyzje te dotyczą. Po drugie, wszystkie decyzje przekazywane na poziom ponadnarodowy wymagają pewnej formy legitymizacji demokratycznej.

\subsubsection{Obszary polityki w Europie - jak przywrócić równowagę?}

Kwestia optymalnej alokacji polityki, czyli powierzenia jej poszczególnych obszarów w gestie różnych szczebli nie jest zagadnieniem nowym. Jej podstawy teoretyczne można znaleźć w klasycznych pozycjach na temat integracji europejskiej, takich jak książka Baldwina i Wyplosza (2012) pod nagłówkiem „teoria federalizmu fiskalnego". Zgodnie z tą teorią, podejmowanie decyzji należy dele- 
gować na szczebel ponadnarodowy tylko wtedy, gdy korzyści z takiego rozwiązania przeważają nad kosztami pozbawienia się części suwerenności. W przeciwnym razie decyzje lepiej jest podejmować na szczeblu krajowym lub nawet lokalnym. I rzeczywiście, ulokowanie kompetencji decyzyjnych na najniższym możliwym szczeblu bez rezygnacji z korzyści netto stanowi sam rdzeń zasady subsydiarności. Poważne korzyści płynące z regulacji ponadnarodowej wynikają z efektów skali i zysków ubocznych, jednak muszą one być zrównoważone przez preferencje krajowe, które stanowią „koszty”.

Zaczynając od kwestii sprawiedliwości, nie ulega wątpliwości, że rozwiązywanie problemów dystrybucyjnych w celu stabilizowania tkanki społecznej kraju jest w największej mierze zadaniem państw narodowych. Państwa członkowskie UE nadal różnią się od siebie dość wyraźnie pod względem krajowych preferencji w zakresie redystrybucji i instytucji państwowych systemów socjalnych. Próżno oczekiwać, że w przewidywalnym czasie upodobnią się one do siebie na tyle, by taka konwergencja umożliwiała zastosowanie w tej dziedzinie odgórnych kompetencji europejskich. Jeżeli jednak pozostawiamy kwestie redystrybucji na szczeblu państw narodowych, to pojawiają się trzy poważne zastrzeżenia. Po pierwsze, przemiany strukturalne wywołują o wiele mniejsze zawirowania w środowisku makroekonomicznym, przyjaznym wobec zatrudnienia, które często pozostaje poza pełną władzą rządów narodowych. Szczególnie w strefie euro ważnymi zagadnieniami, które należy koniecznie brać pod uwagę, są niemal całkowita nieobecność mechanizmu transferów fiskalnych oraz koordynacja polityki ostrożnościowej w skalach mikro i makro. Drugie zastrzeżenie dotyczy umów handlowych, które negocjowane są na szczeblu wspólnotowym, ale często mają różny wpływ na poszczególne kraje członkowskie, które z tego powodu domagają się takiego lub innego mechanizmu transferowego ${ }^{8}$. Trzecim są strategie uchylania się od podatków, stosowane tak w skali europejskiej, jak i globalnej, ograniczając zasoby dostępne na potrzeby redystrybucji - ten problem można próbować skutecznie rozwiązać tylko na szczeblu ponadnarodowym.

Poważnym argumentem na rzecz wyższości rządów wspólnotowych jest europejski jednolity rynek, będący źródłem silnych efektów skali. Oczywiście, czasami krajowe preferencje przemawiają przeciw normom produktowym UE itd.,

8 W 2007 r. UE powołała Europejski Fundusz Dostosowania do Globalizacji (EGF), aby z jego środków współfinansować przywracanie na rynek pracy pracowników, którzy negatywnie odczuli skutki globalizacji. EGF był od początku niedofinansowany - jako pułap jego środków ustalono ok. $0,1 \%$ budżetu UE, a w dodatku ponad $50 \%$ gromadzonych funduszy przeznacza się na łagodzenie konsekwencji makroekonomicznych kryzysu finansowego. Gruntowna analiza na ten temat - zob. Claeys i Sapir (2018). 
ale ogólnie biorąc, korzyści w tym zakresie zdecydowanie górują nad kosztami zrzeczenia się części suwerenności. Jednak bilans kosztów i korzyści nie jest dany raz na zawsze. Na przykład, zwłaszcza w czasach napięć ekonomicznych po ŚKF, zasada „swobodnego przepływu osób”, będąca jedną ze swobód jednolitego rynku, wywołała silne tarcia i uznana została za jeden z czynników wpływających na brytyjską decyzję o brexicie. Właśnie dlatego negocjacje pomiędzy Unią a Wielką Brytanią obracają się wokół (nie-)możliwości uzgodnienia swobodnego dostępu do jednolitego rynku z wyłączeniem swobodnego przepływu osób. W chwili pisania niniejszego artykułu Komisja UE zdecydowanie wyklucza takie rozwiązanie.

Zupełnie inaczej jest ze wspólną polityką zagraniczną, obronną, migracyjną i kwestią ochrony granic zewnętrznych Unii - w tych dziedzinach wspólnota daje ogromne korzyści, jednak dotyczące ich preferencje krajowe były w przeszłości tak skrajnie różne, że obszary te w znacznej mierze pozostały w gestii państw narodowych. Obecnie - przynajmniej w niektórych, jeśli nie wszystkich wymienionych dziedzinach - szybko zmieniająca się sytuacja geostrategiczna coraz wyraźniej przesuwa punkt ciężkości w stronę rządów europejskich.

Istnieją jednak inne ważne obszary, w których przywrócenie równowagi w zakresie rządów jest niezbędne. Dotyczy to przede wszystkim Unii Gospodarczej i Walutowej (UGW). Obecnie panuje ogólna zgoda co do tego, że UGW w postaci zaprojektowanej postanowieniami traktatu z Maastricht z roku 1992 jest unią walutową o poważnych niedomaganiach. Była ona faktycznie próbą stworzenia unii monetarnej bez unii bankowej i bez żadnych mechanizmów transferów fiskalnych. Tymczasem skuteczna obrona przed skutkami wstrząsów asymetrycznych w ramach unii walutowej wymaga posiadania adekwatnych mechanizmów rozkładania ryzyka. Przekładając to na język trylematu Rodrika, oznacza to, że dla dalszego funkcjonowania i trwałości UGW konieczna jest rezygnacja państw członkowskich z częśsi suwerenności w niektórych obszarach (Sander, 2011). Na temat tego, co konkretnie jest niezbędne, można się spierać, niemiej widoczna jest coraz powszechniejsza zgoda co do tego, że oprócz pewnego rodzaju narzędzi podziału ryzyka fiskalnego (np. poprzez Europejski Mechanizm Stabilizacyjny - EMS), decydujące znaczenie ma uzupełnienie europejskiej unii bankowej przez wprowadzenie Europejskiego Systemu Ubezpieczenia Depozytów Bankowych (EDIS) (zob. np. Bénassy-Quéré i in., 2018)9 . W innych dziedzinach, a zwłaszcza w odniesieniu do „fiskalnego kaftana bez-

9 Jednakże - jak wynika z trwającej obecnie debaty w sprawie EDIS - emocje i postawy narodowe niejednokrotnie sprzeciwiają się wprowadzeniu regulacji przynoszących korzyści netto. Poważną przeszkoda dla tego projektu są obecnie szczególnie niemieckie opory przeciw postrzeganemu ryzyku „uwzajemnienia długów”. 
pieczeństwa" nakładanego przez Europejski Pakt Stabilności i Wzrostu, mówi się o tym, że być może wskazana jest „renacjonalizacja” polityki fiskalnej w celu „przywrócenia rządom narodowym kontroli” nad - i trzeba tu dodać: również odpowiedzialności za sposób wykorzystania wpływów podatkowych (Eichengreen i Wyplosz, 2016) ${ }^{10}$. Trudno zaprzeczyć, że rządy te zostały w tym celu wybrane i za te sprawy odpowiadaja one przed swoimi wyborcami. Inaczej mówiąc, rządy w strefie euro wymagają przywrócenia równowagi - nie tylko po to, by zapewnić trwałość funkcjonowania UGW, lecz także, by stawiać czoła wzbierającej fali antywspólnotowego populizmu (Sander, 2016).

Wreszcie, na szczeblu europejskim (i nie tylko) pojawiło się też nowe, ważne i nabierające znaczenia zadanie rozwiązania problemów, jakie niesie ze sobą cyfryzacja i firmy superstar. W tym kontekście rysują się dwa główne obszary wspólnych działań.

Po pierwsze, zasadnicze znaczenie ma posiadanie i prowadzenie wspólnej europejskiej polityki przemysłowej. UNCTAD (2018, s. 128) informuje: „W ciągu dekady, jaka minęła od światowego kryzysu finansowego, dramatycznie wzrosła liczba krajów, które wprowadzają własne, krajowe strategie rozwoju przemysłowego. (...) Kraje na różnych poziomach rozwoju stosują dziś celowe strategie przemysłowe, nakierowane nie tylko na rozwój gospodarczy, lecz mające również zapewniać reagowanie na wszelkiego rodzaju wyzwania naszych czasów. Wśród wyzwań takich można wymienić np. tworzenie miejsc pracy i zmniejszanie skali ubóstwa, uczestnictwo w rewolucji technologicznej i w globalnych łańcuchach wartości (GLW), promowanie produkcji wydajnej, czystej energii i ogólnie gospodarki bardziej przyjaznej dla środowiska". O ile polityki te są często projektowane na szczeblu krajowym, można podać co najmniej dwa argumenty przemawiające za wyższością śmiałej strategii europejskiej w tych dziedzinach. Po pierwsze, globalizacja i cyfryzacja wykazują nierównomierny wpływ na jednolitym rynku europejskim - bardziej niekorzystny zwłaszcza w południowych krajach członkowskich, czemu można by skuteczniej zaradzić narzędziami wspólnotowymi. Po drugie, firmy superstar mają zasięg globalny, ale są głęboko zakotwiczone w swoich krajach pochodzenia, co sugeruje, że dla rozwijania takich branż ważne są warunki krajowe w zakresie wielkości rynku, zaplecza gospodarczego i surowców, jak również zachęt politycznych. Jednolity rynek europejski ma zatem co prawda decydujące znaczenie pod tym względem, ale potrzebuje również uzupełnienia w postaci jednolitego rynku cyfrowego oraz działalności w zakresie wiedzy i doświadczenia, słowem

10 Eichengreen i Wyplosz (2016) twierdzą, że renacjonalizacja polityki fiskalnej wymaga rozwiązania problemu nawisów zadłużeniowych oraz wprowadzenia wiarygodnych przepisów wykluczających pomoc dla przedsiębiorstw zagrożonych upadłością. 
- czegoś w rodzaju Inicjatywy dotyczącej Europejskich Szkół Wyższych. Faktem jest, że inicjatywy takie już istnieją, ale dla ich naprawdę skutecznego działania potrzeba jeszcze odpowiedniej skali ich działań i chęci do przekazywania zasobów za granicę.

Wreszcie, jak już wspomniano, regulacje europejskie można wykorzystać do ustanawiania lub przynajmniej wpływania na globalne normy na obecnie zdecydowanie niedoregulowanych rynkach cyfrowych, co może ostatecznie pomóc Europie w wypracowaniu i kształtowaniu przewag konkurencyjnych w branżach cyfrowych.

\subsubsection{Ku silniejszej legitymacji demokratycznej rządów europejskich}

Rozważana te prowadzą nas do kwestii legitymacji demokratycznej dla procesów decyzyjnych przekazanych na szczebel ponadnarodowy. W tym kontekście najpoważniejszy problem polega na tym, że większość decyzji podejmowana jest na szczeblu międzyrządowym, najczęściej w oparciu o propozycje przygotowane przez Komisję Europejską. Parlament Europejski ma w tych kwestiach pewien udział, ale niewielki, zależnie od konkretnej sprawy. Dlatego legitymacja demokratyczna przeważnie wywodzi się, pośrednio, z wyborów krajowych. To z kolei oznacza, że krajowym wyborcom najczęściej trudno jest prześledzić jakikolwiek związek nowych regulacji z tym, na kogo oddali oni głos przy urnie wyborczej. Czy zatem Europa potrzebuje gruntownej reformy swojej struktury i procedur decyzyjnych w obliczu nowej ekonomii globalnej?

Utrzymanie strategii ,jak gdyby nigdy nic" z jedynie drobnymi korektami wydaje się szczególnie niebezpieczne w obliczu narastającej fali postaw i emocji antywspólnotowych i populistycznych w krajach Unii Europejskiej. Komisja Europejska z pewnością zdaje sobie z tego sprawę. W „Białej Księdze o Przyszłości Europy" (European Commission, 2017) Komisja zestawia pięć różnych scenariuszy. Są to: 1) „kurs dotychczasowy”, czyli dalszy stopniowy postęp w kierunku ,jeszcze ściślejszej unii”; 2) „nacisk na jednolity rynek”, czyli bierne reagowanie na różnice w zakresie preferencji; 3) „kto chce, niechaj robi więcej”, co oznacza dopuszczenie Europy różnych prędkości, również postępującej w kierunku jeszcze ściślejszej unii; 4) koncentracja na wybranych obszarach polityki i na „większej wydajności w załatwianiu spraw”, co może oznaczać nową listę priorytetów, zapewne po dogłębnym rozważeniu kosztów i korzyści; 5) „zróbmy więcej wspólnie”, co z kolei oznacza przyśpieszenie rozwoju ku ściślejszej unii. Chociaż wniesienie przyczynku do analizy procesu przywracania w Europie równowagi w świetle pięciu wymienionych scenariuszy wykracza poza ramy niniejszego studium, omówimy poniżej trzy kwestie w kontekście wspo- 
mnianego wyżej podwójnego wyzwania, niesionego przez globalizację i cyfryzację.

Po pierwsze, istnieje wiele oczywistych obszarów, w których korzyści z czysto ekonomicznego punktu widzenia są olbrzymie: na przykład jednolity rynek o otwartych granicach wewnętrznych, w których europejskie łańcuchy wartości z łatwością zachowują konkurencyjnośćc11; europejska strategia cyfrowa, wykorzystująca dźwignię jednolitego rynku, aby sięgnąć swoimi regulacjami poza Europę; działania na rzecz rozwiązania problemu uchylania się od podatków; promowanie przepisów mających gwarantować stabilność finansową; tworzenie europejskiej przestrzeni wiedzy; wspólnotowe inwestycje w infrastrukturę transportu i komunikacji i szereg innych.

Po drugie, przewagi wynikające ze współpracy są mniej wyraźne w innych dziedzinach, szczególnie w związku z UGW. W istocie, dziś jest sprawą mocno kontrowersyjną czy pierwotny cel i intencje traktatu z Maastricht $w$ tym zakresie są nadal aktualne. Wątpliwości takie prowadzą nas do kwestii scenariuszy: jeszcze ściślejsza unia, czy Europa różnych prędkości, a może Europa wielotorowa? W pierwszym wypadku wszystkie kraje zobowiązane są do wspólnego dążenia do większej integracji we wszystkich dziedzinach (zgodnie z intencją traktatu). Jednak to jest de facto tylko złudzeniem, bo przecież nie wszystkie kraje członkowskie Unii przystąpiły do dziś do UGW czy też do obszaru Schengen. Można by już dzisiaj postrzegać UE jako unię dwóch prędkości, w której kraje członkowskie UGW stanowią szybko integrującą się czołówkę, a reszta podąża $\mathrm{w}$ tyle. Nie wolno przy tym tracić z pola widzenia faktu, że również nie wszystkie kraje członkowskie UGW są gotowe lub chętne do wejścia na szybki tor. W rzeczywistości UE już obecnie jest Europą niejednorodną i to nie dwóch, lecz raczej wielu prędkości. Co więcej, są w niej kraje, które wcale nie podzielają pierwotnej wizji traktatowej, skoro wolą pozostawać poza UGW lub poza Schengen. W tym kontekście słuszniej byłoby mówić o Europie wielu torów, a problemem takiej wielotorowości jest ryzyko, że członkowie zechcą wydłubywać rodzynki z ciasta, czyli z całości wybierać to, co im najbardziej odpowiada. Ryzyko takie należy akceptować i wyważyć względem innego zagrożenia, mianowicie wzrostu niechęci lub nawet sprzeciwu wobec dalekiej ingerencji rządów europejskich, zwłaszcza w nowych państwach członkowskich. W każdym razie

11 Nie wymieniłem tu takich dziedzin, jak migracje, bezpieczeństwo i polityka zagraniczna, ponieważ nie wchodzą one w zakres zainteresowań niniejszego studium. Niemniej, ażeby pozbawiona granic wewnętrznych strefa Schengen mogła bez przeszkód funkcjonować, konieczna może się okazać skuteczniejsza, a więc realizowana wspólnie kontrola granic zewnętrznych, przy czym w kontekście niniejszych rozważań argument ten opieramy na przesłankach czysto ekonomicznych. 
atrakcyjność uczestnictwa w większej liczbie lub nawet we wszystkich sferach integracji europejskiej w ramach porządku wielotorowego zasadniczo zależy od „legitymizacji wyników”. Jak pokazaliśmy powyżej, istnieje wiele dziedzin, w których europejskie wspólnotowe działania polityczne pozwalają znacznie lepiej radzić sobie $\mathrm{z}$ wyzwaniami globalizacji w porównaniu z poprzestaniem na polityce czysto krajowej w świecie firm superstar i wschodzących nowych superpotęg, takich jak Chiny. Jeżeli Europa ma funkcjonować skutecznie, to porządek wielotorowy nie może stanowić zagrożenia dla integracji europejskiej - przeciwnie, powinien on wspierać integrację zawsze i wszędzie tam, gdzie jest to konstruktywne i korzystne.

Po trzecie i ostatnie, niezbędna jest „legitymizacja wkładu”. Debata o legitymacji demokratycznej dla europejskich procesów decyzyjnych jest złożona i obraca się wokół wzmocnienia kompetencji Parlamentu Europejskiego. W kontekście tym pojawia się wiele propozycji, których dokładniejsze omówienie dalece wykracza poza ramy niniejszego studium. Tutaj należy jedynie odnotować, że propozycje reform zależą zasadniczo od tego, jakie stanowisko zajmuje się względem prędkości integracji - jednej versus wielu - oraz jej porządku: jedno- lub wielotorowego. Przykładowo, zespół skupiony wokół francuskiego ekonomisty Thomasa Piketty'ego, o postawie proeuropejskiej zaleca wzmocnienie kompetencji Parlamentu Europejskiego oraz utworzenie "Zgromadzenia strefy euro" (Hennette i in., 2017). Z kolei Eichengreen (2018) krytykuje takie podejście jako rozwiązanie w najlepszym razie niepełne, bo oparte - jego zdaniem - na przestarzałej wizji Europy dwuprzęsłowej, w której strefa euro stanowi przęsło główne. Badacz ten proponuje coś innego: wyposażyć istniejący Parlament Europejski w kompetencje proporcjonalnie do tego, które państwa członkowskie uczestniczą w których strefach, instytucjach i politykach Wspólnoty w ramach wielotorowej Europy. Na przykład, członkowie parlamentów krajów strefy euro głosują w sprawach tejże, przedstawiciele krajów strefy Schengen w sprawach dotyczących Schengen i tak dalej. W ten sposób Eichengreen (2018) liczy na to, że „Parlament stałby się przekaźnikiem woli ludzi i umożliwiłby im demokratyczną kontrolę w tym sensie, że technokraci z Komisji, z EBC, i z innych instytucji UE byliby przed nimi demokratycznie odpowiedzialni - z tym, że głos i kontrolę zyskaliby nie wszyscy, lecz ludzie właściwi to jest obywatele tych krajów, które zgodzity się scedować w danym zakresie swoje narodowe prerogatywy". Jak również - co Eichengreen dodaje pod koniec swojej książki - rozwiązanie takie mogłoby ostatecznie nawet pomóc w powstrzymaniu fali populizmu antyeuropejskiego wzmagającej się na kontynencie. 


\section{Europejska agenda polityczna w i na rzecz nowej ekonomii globalnej}

Europa stoi w obliczu potrójnego wyzwania - odnalezienia się w dobie globalizacji, cyfryzacji oraz przybierających na sile postaw antyeuropejskich w Unii i populizmu w innych krajach. Czynnikiem, który sprawia, że wyzwaniom tym jest tak trudno sprostać są ich głębokie i zawiłe współzależności. Nowe technologie napędzały proces globalizacji dawniej i będą napędzać go nadal, choć zmieni się charakter tego wpływu. Konsekwencje socjoekonomiczne tych procesów są złożone i powiązane, a polityka nie zajmuje się nimi w stopniu dostatecznym, co zwiększa niepewność ekonomiczną w wielu krajach Europy i coraz poważniej zagraża stabilności jej klasy średniej.

Jednakże w wielu sytuacjach zjednoczona Europa lepiej niż małe państwa narodowe jest przygotowana do pokonania problemów, jakie niesie ze sobą globalizacja i globalne firmy superstar. Przede wszystkim, wspólnota jest w stanie wykorzystać swój olbrzymi jednolity rynek, by wpływać na ukształtowanie takiej globalnej agendy, w której ludzie stawiani będą na pierwszym miejscu w porządku globalnych spraw ekonomicznych. W ten sposób można doprowadzić do ustalenia lepszych globalnych przepisów regulujących biznes cyfrowy, prawa pracownicze, stabilność finansową, inwestycje transgraniczne, przepływ wiedzy i inne dziedziny.

Niemniej, warunkiem, od którego wszystko to zależy jest silna, funkcjonalna Unia Europejska o mocniejszej legitymacji demokratycznej. Maksyma Jeana Monnet: „L'Europe se fera dans les crises et elle sera la somme des solutions apportées à ces crises" [Europa wykuwać się będzie w kryzysach i stanowić będzie sumę rozwiązań, jakie wypracuje, by kryzysy te pokonać ] zapewne sprawdzała się w przeszłości. W świecie zglobalizowanym, cyfrowym, pozbawionym łagodnego i dobroczynnego hegemona, gwaranta światowego porządku ekonomicznego opartego na zestawie jasnych i wspólnych reguł, Europa musi podjąć się nowej roli - roli jednej z trzech superpotęg. Jeżeli Europa ma mieć zdolność faktycznego współkształtowania przyszłości globalnej gospodarki, musi zdecydować się na działanie i wykonać duży, pewny krok naprzód, nie czekając na kryzysy i nie poprzestając na wydobywaniu się z nich.

Europa potrzebuje przebudzenia. Musi działać proaktywnie w trzech dziedzinach naraz: wzmacniać metodami demokratycznymi legitymizację prowadzonej przez siebie polityki, osiągać dobre wyniki w zakresie stanu majątku, prosperity mieszkańców i stabilności oraz wziąć na siebie globalną odpowiedzialność za gospodarkę światową - po to, by nowa ekonomia globalna stała się lepszym środowiskiem do pracy i do życia. 


\section{Bibliografia}

Acemoglu, D. i Restrepo, P. (2018). Modeling automation. American Economic Review Papers and Proceedings, 108, 48-53.

Autor, D., Dorn, D., Katz, L.F., Patterson, C. i Van Reenen, J. (2018). The fall of the labor share and the rise of superstar firms. MIT mimeo updated from NBER Working Paper.

Baldwin, R. (2006). Globalization: The great unbundling(s). Prime Minister's Office: Economic Council of Finland. Eu2006.fi.

Baldwin, R. (2016). The great convergence: Information technology and the new globalization. Cambridge, MA.: Harvard University Press.

Baldwin, R. i Wyplosz, C. (2012). The economics of European integration. $4^{\text {th }}$ edition. Maidenhead: McGraw-Hill.

Bénassy-Quéré, A. i in. (2018). Reconciling risk sharing with market discipline: A constructive approach to euro area reform. CEPR Policy Insight 91, January. London: CEPR.

Claeys, G. i Sapir, A. (2018). The European globalisation adjustment fund: Easing the pain from trade? Bruegel Policy Contribution 5. Brussels: Bruegel.

Couré, B. (2017). Sustainable globalization: Lessons from Europe. Speech at the Workshop "Financial globalization and its spillovers - monetary and exchange rate policy in times of crises". Special public event " 25 years after Maastricht: The future of money and finance in Europe", February 16. Maastricht. Acquired from: https://www.ecb.europa. eu/press/key/date/2017/html/sp170216.en.html.

Constantinescu, C., A. Mattoo i Ruta, M. (2017). Trade developments in 2016: Policy uncertainty weighs on world trade. February 21. Washington DC: World Bank Group.

Draghi, M. (2017). Sustaining openness in a dynamic global economy. Speech at the Economic Policy Symposium of the Federal Reserve Bank of Kansas City, Jackson Hole, 25 August. Acquired from: https://www.ecb.europa.eu/press/key/date/2017/html/ecb.sp170825.en.htm.

Eichengreen, B. (2018). The populist temptation: Economic grievance and political reaction in the modern era. Oxford: Oxford University Press.

Eichengreen, B. i Wyplosz, C. (2016). Minimal conditions for the survival of the Euro. In: Baldwin, R. and F. Giavazzi (eds.). How to fix Europe's monetary unions: Views from leading economists. London: A VoxEU.org eBook. CEPR.

European Commission. (2017). White paper and the future of Europe: Reflections and scenarios for the EU27 by 2015. Brussels: European Commission.

Funke, M., Schularick, M. i Trebesch, C. (2015). Going to extremes: Politics after financial crises, 1870-2014. CESifo Working Paper No. 5553. October.

Guiso, L., H. Herrera, M. Morelli, M. i Sonno, T. (2018). Global crises and populism: The Role of Eurozone institutions". EIEF Working Papers Series 1806. Rome: Einaudi Institute for Economics and Finance.

Hennette, S., Piketty, T., Sacriste, G. i Vauchez, A. (2017). Pour un traité de démocratisation de l'Europe. Paris: Editions du Seuil.

IMF. (2017). World Economic Outlook April 2017. Washington DC: International Monetary Fund.

IMF. (2018). World Economic Outlook April 2018, Chapter 4. Washington DC: International Monetary Fund.

Lakner, C. i Milavonic, B. (2013). Global income distribution: from the fall of the Berlin Wall to the great recession. The World Bank. Policy Research Working Paper 6719, December. Washington DC: World Bank. 
Lane, P.R. i Milesi-Ferretti, G.M. (2017). International Financial Integration in the Aftermath of the Global Financial Crisis. IMF Working Paper WP/17/115. Washington DC: International Monetary Fund.

Marin, D., Veugelers, R. i Felia, J. (2017). A revival of manufacturing in Europe. Recent evidence about reshoring. In: Veugelers, R. (ed.), Remaking Europe: The new manufacturing as an engine of growth (p. 102-125). Bruegel Blueprint Series 26. Brussels: Bruegel.

McCauley, R. (2011). De-internationalizing global banking? Comparative Economic Studies, 56(2), June, 257-270.

McCauley, R., Bénétrix, A.S., McGuire, P.M. i von Goetz, P. (2017). Financial deglobalisation in banking? Trinity Economic Papers No. 1717, July. Dublin: Trinity College.

Nordhaus, W.D. (2015). Are we approaching an economic singularity? Information technology and the future of economic growth. Cowles Foundation Discussion Paper No. 2021. New Haven, CT: Cowles Foundation.

Rodrik, D. (2011). The globalization paradox. Democracy and the future of the world economy. New York and London: W.W. Norton \& Co.

Rodrik, D. (2017). It's time to think yourself on free trade. Foreign Policy, January 27. Acquired from: https://foreignpolicy.com/2017/01/27/its-time-to-think-for-yourself-onfree-trade/.

Sander, H. (2011). Europe must grapple with the debt crisis now. The Conversation: Global Perspectives. May 18. Acquired from: https://theconversation.com/europe-must-grapplewith-debt-crisis-now-1264.

Sander, H. (2016). Renationalising fiscal policy would help rebuild support for the EU. EUROPP Blog: European Politics and Policy. London School of Economics and Political Science. Acquired from: http://bit.ly/2bAYUYx.

UNCTAD. (2017). World Investment Report 2017. Geneva: United Nations Conference on Trade and Development.

UNCTAD (2018). World Investment Report 2018. Geneva: United Nations Conference on Trade and Development.

Tørsløv, T., Wier, L. i Zucman, G. (2018). The missing profit of nations. NBER Working Paper 24791. Cambridge, MA: NBER.

Van Reenen, J. (2018). Increasing differences between firms: Market power and the macroeconomy. Economic Policy Symposium of the Federal Reserve Bank of Kansas City, Jackson Hole, 29 July.

Williamson, J. (1990). What Washington means by policy reform. In: J. Williamson, (ed.): Latin American readjustment: How much has happened. Washington DC: Institute for International Economics. 


\section{ANDRZEJ SOPOĆKO}

\section{Sekularne procesy strukturalne. Nieoczekiwane rezultaty}

Gospodarki poszczególnych krajów są coraz bardziej zintegrowane ze swoim otoczeniem zarówno bliższym, w postaci głównych partnerów w handlu zagranicznym, jak i dalszym, czyli krajów dostarczających specyficzne, niezbędne jednak dla wytwarzania dobra. Nie można prowadzić biznesu bez ciągłej analizy sytuacji poza krajem, nie tracąc z oczu obszarów nawet bardzo odległych. Dla polityki gospodarczej fakt ten ma podstawowe znaczenie. Procesy zachodzące w systemie światowej gospodarki muszą być punktem wyjścia jakichkolwiek działań dostosowawczych oraz chroniących przed niekorzystnymi zdarzeniami i procesami (np. zalew plastikowych śmieci czy ceny transferowe).

Zależności te ograniczają zakres działania państwa, wymagając głębokiej analizy obszarów, gdzie to działanie jest możliwe i efektywne. Doświadczenia starej polityki strukturalnej dowodzą, że bezpośrednie ingerencje w sferę wytwarzania nie mają przed sobą przyszłości. Zagadnienie, gdzie obecnie można przyspieszyć rozwój za pomocą oddziaływań państwa - również jest przedmiotem zainteresowania w tej książce. W tym fragmencie rozważany jest $w$ istocie jeden z procesów, który, jak się wydaje, powinien być ujęty w karby działań regulacyjnych. Należy on nie tyle do gospodarki sensu stricto, ile do obszaru relacji społecznych wywołanych mechanizmami ekonomicznymi. Chodzi tu o problem narastających dysproporcji majątkowych i społecznych, który nie daje się pogodzić z wiodącymi współcześnie wartościami, jak demokracja i solidarność społeczna. Przeciwdziałanie wspomnianemu zjawisku nie jest przedmiotem przedstawionej tu analizy. To mógłby być kolejny etap pracy. Tu ograniczono się jedynie do zadania pytania: co i dlaczego w gospodarce przyczynia się do powstawania dysproporcji dochodowych. Autor stara się określić, tkwiące w samym mechanizmie wytwarzania, przyczyny bogacenia się bogatych i systematycznej redukcji warstwy średniej z punktu widzenia uzyskiwanych dochodów. Szczególny nacisk położony został na badanie udziału w narastaniu tego zjawiska procesów cyfryzacji, automatyzacji i zastosowań sztucznej inteligencji.

Słowa kluczowe: dysproporcje dochodowe, globalizacja, cyfryzacja, sekurytyzacja.

\section{Najważniejsze procesy kształtujące system wytwarzania i podziału}

Signum temporis obecnych przemian jest ujawnienie się trzech czynników zmieniających zarówno gospodarkę, jak i społeczeństwo, czyli:

- globalizacji,

- sekurytyzacji,

- cyfryzacji i sztucznej inteligencji. 
Wspólnym mianem tych procesów jest zaskakujący charakter ich skutków. Nie są one bowiem takie, na jakie wskazywałaby intuicja, względnie tzw. zdroworozsądkowe spekulacje. Obserwowane zjawiska okazały się wręcz odwrotne od oczekiwanych, a najwcześniej odkryto to w przypadku procesu globalizacji.

Globalizacja, prowadząc do głębokiej, międzynarodowej specjalizacji produkcji powinna sprzyjać wykorzystywaniu lokalnych przewag komparatywnych i podnosić poziom globalnego dobrobytu. Okazuje się jednak, że proces ten miał miejsce przede wszystkim w grupie krajów wysoko rozwiniętych, które poszły w kierunku coraz bardziej zintegrowanego systemu wytwarzania, ukształtowanego wewnątrz ponadregionalnego „światowego trójkąta” (Ameryka Płn., Europa, Azja Wsch.). Globalizacja nie przyczyniła się do wyrównania poziomu dochodów na świecie. Zamiast oczekiwanego przepływu kapitału z wolniej rozwijających się ku krajom o niższym poziomie PKB, występuje od lat zjawisko odwrotne, tj. tzw. up hill capital flow (Prasad, Rajan i Subramanian, 2007). W rezultacie różnice między krajami w sferze zasobności majątku produkcyjnego nie zmalały, lecz jeszcze się pogłębiły. Okazuje się także, że globalizacji towarzyszy zwiększanie się różnic dochodowych wewnątrz krajów, szczególnie w grupie słabiej rozwiniętych. Jacek Tomkiewicz, opierając się na badaniach własnych oraz pracy Nomaana Majid, pisze że „im gospodarka jest bardziej otwarta, tym wzrost gospodarczy w mniejszym stopniu przekłada się na spadek ubóstwa i szybciej rosną nierówności dochodowe" (Tomkiewicz, 2017, s. 29; Majid, 2010).

W sferze czysto ekonomicznej skutkiem globalizacji jest rozkooperowanie produkcji po całym świecie. Złożone produkty składane są z części pochodzących z różnych jego zakątków. Tym sposobem składane gdzieś tam towary z części wytwarzanych na całym świecie tracą swoją identyfikację narodową na rzecz identyfikacji z ponadnarodową marką. To z kolei prowadzi do umiędzynarodowienia kadry zarządzającej, która przynajmniej w pracy musi reprezentować kosmopolityczne postawy oraz globalny, a nie narodowy punkt widzenia w swojej działalności zawodowej. W tej sytuacji rola państw w kształtowaniu struktury produkcji, jak również relacji społecznych wewnątrz przedsiębiorstwa staje się bardzo ograniczona. Wysokość płac i ich struktura są coraz bardziej odbiciem zależności i uwarunkowań globalnych, a nie krajowych. Płaci się tak, jak dyktuje światowy rynek pracy. Regulacje krajowe mogą co prawda poprawić sytuację w przedsiębiorstwie, istnieje jednak wówczas ryzyko wyłączenia go z międzynarodowej sieci przepływów produktowych.

Zaskakujące są także rezultaty cyfryzacji i robotyzacji w gospodarce. Pod koniec minionego wieku wydawało się, że będą one miały wpływ na ograniczenie zapotrzebowania na pracę. Roboty zastępują przecież człowieka, im więcej 
zatem robotów, tym mniejsze zapotrzebowanie na pracowników. I niewątpliwie jest to prawda, tyle że - w skali mikro. Jeśli bowiem w jednym miejscu automaty redukują liczbę miejsc pracy, to w innym miejscu jednocześnie je tworzą. Wyrafinowane technicznie urządzenia muszą być przecież gdzieś produkowane i przez kogoś serwisowane. Instalacja i utrzymywanie ich wymaga specjalistycznej wiedzy i kwalifikacji. Rozwinięcie stosownych komórek organizacyjnych realizujących takie zadania wewnątrz każdego przedsiębiorstwa jest nieopłacalne. Powstają więc specjalistyczne firmy i zakłady usługowe, obsługujące przedsiębiorstwa użytkujące urządzenia określonego typu. Występuje tu podobna sytuacja, jak w dziedzinie napraw i serwisu samochodów. Kiedyś były to zakłady uniwersalne, zajmujące się dowolną marką pojazdu. Obecnie są one wypierane przez wyspecjalizowane serwisy, autoryzowane przez konkretnych wytwórców. Dodatkowo wewnątrz tych serwisów również występuje specjalizacja (np. są jednostki zajmujące się jedynie skrzyniami biegów, elektryką). Przybywa różnego rodzaju firm usługowych, które muszą trwać w gotowości, by podtrzymać złożony system gospodarki. Są one w stanie stosunkowo szybko usuwać awarie i dokonywać zmian w parku maszynowym. Bez nich byłby on narażony na przestoje i niedobory powodujące sekwencję strat $\mathrm{w}$ jego bliższym i dalszym otoczeniu. Posiadając stosowne doświadczenie i wiedzę, firmy takie pozwalają na płynne implementacje nowych procedur i potrzebnych produktów. Outsourcing jest więc nieodłącznym elementem rozwoju.

Najbardziej spektakularne są usługi ośrodków programowania, przeprowadzania strukturalizacji wytwarzania, automatyzacji itp. Zapotrzebowanie na nie wzrasta ponad proporcjonalnie do PKB, to zaś podnosi ich cenę. Poszukiwani pracownicy z tego obszaru, świadomi swojej relatywnej rzadkości, dyktują warunki zatrudnienia. Chodzi nie tylko o płacę, lecz także odpowiednią ofertę warunków życia, co wiąże się z kosztowną infrastrukturą (mieszkania, oferta kulturalna, sportowo-rekreacyjna itd.). Poszczególne regiony, a nawet kraje muszą spełniać te wymagania, w przeciwnym razie nastąpi niebezpieczny drenaż tej obecnie najcenniejszej kadry ku ośrodkom z lepszą ofertą pracy i życia w ogóle.

Podobny efekt wywołuje sekurytyzacja gospodarki. Jest to sytuacja nieoczekiwana, ponieważ jeszcze $\mathrm{w}$ drugiej połowie $\mathrm{XX}$ wieku wydawało się, że proces ten, przyczyniając się do upowszechnienia własności, sprzyjać będzie przy okazji wyrównaniu dochodów. Nawet jeśli nie wszyscy się z tym zgadzali, to przez długi czas nie dostrzegano żadnych przesłanek rozciągania struktury dochodów spowodowanego tym procesem.

Okazało się jednak, że sekurytyzacja, stanowiąc pozornie upowszechnienie własności, spowodowała głęboką redukcję wpływu właścicieli na proces wytwa- 
rzania. W rezultacie nastąpiła minimalizacja znaczenia nadzoru własnościowego. W rzeczywistości zaś instytucją oceniająca nie jest żaden statutowy organ spółki, ale rynek giełdowy, gdzie kursy akcji stają się podstawowym wymiarem wartościowania przedsiębiorstwa. Strategiczna rola właściciela staje się fikcją. O tym, jakie przedsiębiorstwo jest i jakim będzie decydują menedżerowie zasiadający w gremiach wykonawczych spółki (zarząd, CEO). To zaś określa w znacznej mierze całą strategię przedsiębiorstwa. Ponieważ kursy akcji są bieżącą miarą jego efektywności, misją organów wykonawczych jest tak nimi sterować, by w okresie trwania kadencji menedżerów były jak najwyższe. O ile tradycyjnie uważano, że kadra kierownicza powinna utożsamiać się z produktem (m.in. buty Baty, kamery Leica, odkurzacze Elektrolux), o tyle obecnie dominuje utożsamianie się z zyskiem i rentownością. Prowadzi to do poszerzania i zmian profilu produkcji, który podąża za branżowymi rankingami efektywności.

Obecnie podkreśla się, że nie występuje teraz kapitalizm w sensie schumpeterowskim. Przedsiębiorczość przestaje być związana z własnością kapitału. O funkcjonowaniu dużych przedsiębiorstw niesłychanie rzadko decydują takie osobowości, jak bracia Michelin, Ferdynand Porche, w Polsce - Kazimierz Szpotański czy Hipolit Cegielski. Współczesnym wzorcem jest miliarder, który ma stale zmieniający się portfel aktywów finansowych. On spotyka się ze swoim doradcami co parę dni. Wtedy słucha, jakie pozycje tego portfela wymienić na inne. Kryterium jest oczywiście krótkookresowa efektywność elementów tego portfela, przede wszystkim - akcji spółek. Poza rzadkim sytuacjami, lista celów jego działalności ogranicza się do tego jednego.

Typowy kapitalista nie zarządza tymi spółkami. W tym procesie zajmuje bierną postawę. Energię kieruje nie na sferę wytwarzania, lecz bieżące kształtowanie pozycji portfelowych. Wybiera, a w istocie - akceptuje propozycje włączenia do niego aktywów, które obecnie rokują szansę na najwyższą stopę zwrotu, pozbywając się tych, które pod tym względem wypadają słabiej. Sam jednak dla zwiększania ich produktywności w zasadzie nie robi nic.

Na wartość spółki pracują menedżerowie, czyli CEO. Od ich strategii zależy czy akcje spółki osiągną odpowiednio wysoką dynamikę, przez co staną się obiektem zainteresowania właścicieli finansowego kapitału. Starają się więc w krótkim okresie wycisnąć ze spółki jak najwięcej, by uzyskane wyniki przyciągnęły pieniądze inwestorów. Pracują na takie efekty, które mogą ich od razu zainteresować - na krótkotrwałe zyski. Długofalowe strategie rozwojowe schodzą w tej sytuacji na dalszy plan.

W warunkach ograniczonego popytu najbardziej perspektywicznym działaniem służącym podniesieniu rentowności jest obniżka kosztów. W długim okresie dokonać tego można przez odpowiednie inwestycje, ta perspektywa jednak 
schodzi na dalszy plan. Decydujący o przedsiębiorstwie najwyżsi rangą menedżerowie mają kontrakty kilkuletnie. Ten więc horyzont czasowy jest dla nich najważniejszy i w tym czasie powinni się wykazać wysoką efektywnością. W tych warunkach najskuteczniejszym sposobem jej zwiększenia jest cięcie kosztów, szczególnie ich głównej pozycji - płac. Wewnątrz standardowego, dużego przedsiębiorstwa występuje więc mechanizm tłumienia wzrostu wynagrodzeń, tłumacząc przynajmniej częściowo stagnację mediany dochodowej.

Można więc powiedzieć, że w dużych korporacjach występuje następująca sekwencja zdarzeń:

- właściciele kapitału finansowego szukają możliwości zainwestowania dużych porcji środków w spółki, dające w perspektywie kilku lat wysokie i stabilne stopy zwrotu;

- kierujący korporacjami menedżerowie, aby być atrakcyjnymi dla właścicieli kapitału finansowego, kierują swoją aktywność przede wszystkim na ograniczenie płac, bo jest to w tym okresie najwydajniejsza droga podnoszenia stopy zwrotu z pasywów (kapitału) spółki;

- skutkiem takiej postawy menedżerów jest silne hamowanie wzrostu dochodów, co przekłada się na hamowanie popytu osób żyjących z pracy najemnej, czyli o dochodach w pobliżu lub poniżej mediany.

Oczywiście gospodarki nie tworzą wyłącznie duże korporacje. Nie obejmują także większości zatrudnionych. Nie tyle jednak ważny jest ich udział w tworzeniu PKB, ile znaczenie w kształtowaniu się wzorców zarządzania. Tu zaś nie mają konkurencji. Są one biznesowymi liderships. O nich pisze się w gazetach i studiuje na uczelniach. Pozostali, obserwują tych „dużych chłopców”, snując domniemania, że metody przez nich stosowane są najlepsze, no bo jak inaczej osiągnęliby swoją pozycję. Mamy więc do czynienia z szerokim naśladowaniem poczynań menedżerskich wielkich korporacji w całej reszcie gospodarki. Dotyczy to także stosunku do wzrostu płac.

Wspomniane zjawisko nie wydaje się możliwe do zatrzymania. Wzorzec firmy, gdzie skrupulatnie szuka się oszczędności, głównie w płacach i zatrudnieniu, nie wydaje się mieć alternatywy w obecnej, nasilonej, globalnej konkurencji. Wynikające stąd ograniczenia wzrostu dochodów pracowników i generowanego przez nich niskiego popytu trzeba, jak się wydaje, przyjąc jako zjawisko obiektywne. Dla części z nich idzie w sukurs proces wymuszeń innowacyjnych („nie unowocześniasz, wypadasz z rynku"), który tworzy rosnący popyt na pracowników o bardzo wysokich kwalifikacjach i sprawności intelektualnej. Statystyka wynagrodzeń ogółem wskazuje jednak, że nie jest to cześć dominująca, ponieważ w przeciwnym wypadku odnotowywano by ich znaczący wzrost. 


\section{Stan i zagrożenia wzrostu stratyfikacji społecznej}

Zmiany relacji międzybranżowych gospodarki i związanej z nią struktury zatrudnienia wypada potraktować jako naturalną konsekwencję rozwoju. Jak wspomniano, niewiele można w tym wymiarze zdziałać, ponieważ ryzyko nietrafionych wzorców struktury produkcji jest bardzo wysokie. Gospodarka może układać swoje relacje wewnętrzne sama i choć można oceniać to w różny sposób, lepiej powstrzymywać się od bezpośrednich interwencji. Inaczej jest jednak w sferze społecznej. Trudno przecież pozostawać obojętnym wobec skutków, gdy wydają się uderzać w podstawy uniwersalnego systemu wartości. Mamy obecnie do czynienia z sekularnymi procesami kształtowania rozwarstwienia społecznego i społecznej stratyfikacji. Wydają się one w zauważalnym stopniu niweczyć osiągnięcia ery nowożytnej w zakresie demokracji, jak i pokoju społecznego. Niegdysiejszą walkę klas wydaje się zastępować coraz ostrzejsza konfrontacja rosnącej grupy niezadowolonych z niewielką grupą beneficjentów zmian, znajdujących się w górnych decylach dochodowych.

Zróżnicowanie dochodowe jest naturalnym efektem każdej gospodarki. Nigdzie się nie udało wprowadzić utopijnych wzorców powszechnej równości, począwszy od „utopii” Tomasza Morusa i Tomasza Campanelli („Państwo Słońca"), nie mówiąc o komunizmie, którego weryfikacja kosztowała życie milionów ludzi. Względnie najbardziej udane implementacje takich systemów, w postaci izraelskich kibuców, uległy daleko idącej erozji, przez co tęsknoty za powszechną równością zaliczyć należy do mitów, które obecnie nie odgrywają żadnej roli.

O ile jednak egalitaryzm społeczny nie stanowi dzisiaj żadnej atrakcyjnej społecznej propozycji, o tyle pogarszanie się relacji między biednymi a bogatymi spotyka się z coraz większym sprzeciwem. Jest to niezgodne z paradygmatem równych szans, jaki zastąpił mit równości. Znaczna część społeczeństwa uważa, że te szanse maleją wraz z dochodowym rozwarstwieniem. Uzyskanie lepszej pozycji społecznej staje się bardzo trudne dla osób z ubogich rodzin. Amerykański mit, według którego pucybut może zostać milionerem już tylko śmieszy.

Otóż możliwość płynnego awansowania, tzn. sytuacja, gdy każdy ma szanse przesunąć się o szczebel wyżej, wymaga odpowiedniego ku temu systemu społecznego. Powinien on zapewnić ciągłość wertykalnej struktury społecznej, w której poszczególne szczeble są stosunkowo bliskie siebie i w miarę równych odległościach. Nie powinno być więc tak, że po osiągnieciu pewnej pozycji niezbędny jest, nieporównywalny w stosunku do poprzednich etapów, skok wysiłków i determinacji. Niestety niesione przez przemiany gospodarcze przemiany społeczne właśnie do tego zmierzają. Istnieje wyraźna tendencja ku uksztalto- 
waniu się dualistycznego modelu, w którym wyraźnie zaznaczają się dwie warstwy: bardzo dobrze sytuowanych i biednych, z trudnością walczących o utrzymanie poziomu życia powyżej stanu społecznego wykluczenia. Kurczy się grupa, których dochody były pomiędzy bogatymi a średnio zamożnymi. To co kiedyś było solidnym filarem społeczeństwa, tj. klasa średnia, ma coraz mniejsze znaczenie, ponieważ liczebność tej grupy stale spada. Szczególnym skutkiem działania tych procesów jest, specyficzny dla tej struktury zatrudnienia i dochodów, wzrost liczby zatrudnianych okresowo oraz zamiany oferty pracy w kierunku niskopłatnych stanowisk.

W tej sytuacji trudno oprzeć się wizji powrotu modelu społecznego sprzed rewolucji przemysłowej. W XVIII wieku we Francji, jak i zresztą w innych krajach europejskich, istniały pod względem dochodowym dwie grupy społeczne: arystokracja i reszta składająca się z chłopów i miejskich rzemieślników. O ile ci pierwsi żyli dostatnio, a często wręcz rozrzutnie, o tyle reszta często (w okresie nieurodzaju) cierpiała głód. Arystokracja była pod opieką króla (regularnie spłacał nawet jej długi), pozostała część społeczeństwa przeżywała zaś kolejne klęski głodu. Widowiskową (a to ma znaczenie) egzemplifikacją tej struktury był Wersal, składający się z pałacu, gdzie żył król i arystokracja (ok. 3 tys.), oraz miasta Wersal, które w większości było zamieszkałe przez służbę tej ostatniej (1789 r. - 60 tys.) (La Grande Encyclopedie, 1902, s. 886). Obecna rzeczywistość jest w niektórych krajach bynajmniej niezbyt daleko odbiegła od tego wzorca. Przykładowo, $16 \%$ ludności Rosji żyje poniżej progu ubóstwa, natomiast rosyjska oligarchia, która w tym kraju zajęła miejsce dawnej arystokracji to $10 \%$ najbogatszych posiadających $87 \%$ bogactwa kraju (w USA - 76\% majątku; w Chinach - 67\%) (Walker, 2017). Zbliżone relacje występują w krajach latynoskich, znanych skądinąd z częstych przewrotów czy wręcz rewolucji. Rządy poszczególnych krajów są protektorami „super-bogatych” jak świat długi i szeroki. Podobnie jak niegdyś arystokraci, tak dzisiaj wielkie koncerny coraz mniej podatków płacą w kraju, gdzie prowadzą swoją działalność. Curiosum jest koncern Google, który ma siedzibę w Stanach Zjednoczonych, zatrudnia też przede wszystkim obywateli tego kraju (łączenie zatrudnienie 88 tys.) (Statista, 2018), jednak nie płaci ani centa podatku federalnego na terenie USA. Głęboko zredukowany jest także podatek stanowy (tylko w stanie Iowa łączna redukcja tego podatku wyniosła 48 mln USD) (Sverdlik, 2015).

Ani w XVIII wieku, ani obecnie nieregularna „piramida” dochodowa nie powstała jednak wskutek działań regulacyjnych rządu. Ukształtowana została przez znacznie silniejsze czynniki, mające charakter uniwersalny.

W przeszłości zróżnicowanie dochodów stanowiło naturalny skutek funkcjonowania ustroju feudalnego, opartego na kryterium „dobrego urodzenia” 
i majątku. Majątek pozostaje oczywiście jako kryterium różnicowania społecznego, istotne znaczenie ma jednak zdolność wejścia i utrzymania się w górnej warstwie społecznej, do której należą, poza właścicielami kapitału, tzw. top management, wolne zawody, pracownicy nauki. Problem w tym, że wejście to coraz więcej kosztuje. Tworzy się zaklęty krąg, w którym na pytania jak zostać bogatym, odpowiada się - być bogatym wcześniej.

Dane statystyczne wskazują, że dochód uboższych części społeczeństwa nie rośnie, mimo wzrostu PKB. Tak dzieje się zarówno w USA, jak i w Unii Europejskiej.

Wykres 1. Mediana dochodów ludności oraz PKB w USA

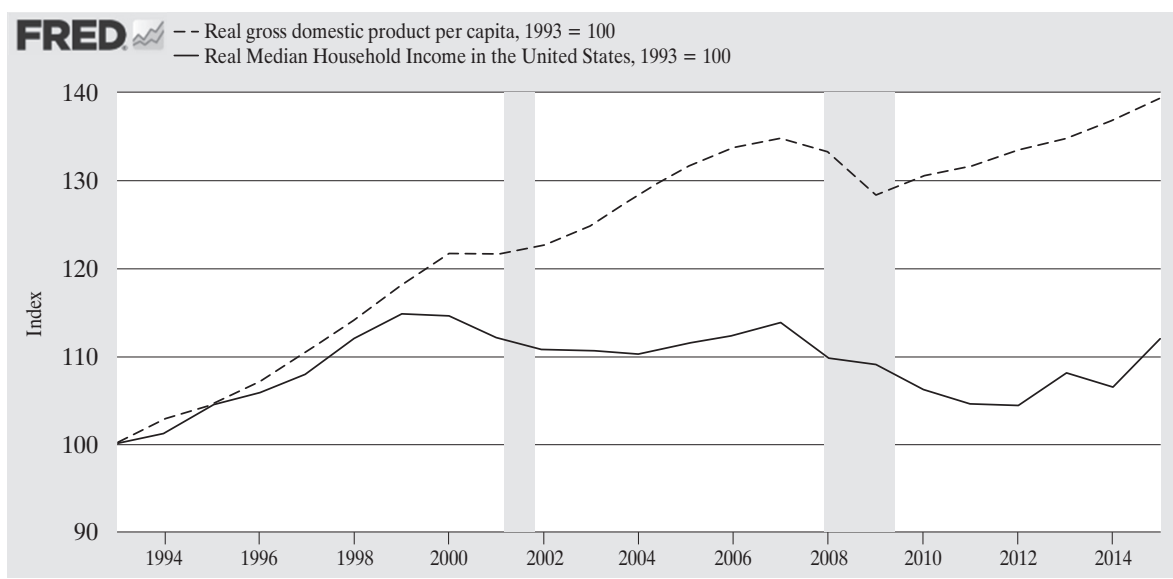

Źródło: U.S. Bureau of Economic Analysis, 2018.

To rozejście się krzywych wzrostu PKB i uboższej połowy ludności oznacza przyspieszenie procesu bogacenia się zamożniejszej części społeczeństwa. Dotyczące USA dane są powszechnie znane i nie wydaje się potrzebne jeszcze raz je przytaczać (wykres 1). Okazuje się jednak, że proces ten zachodzi także w Unii Europejskiej, co zaprezentowano na wykresie 2.

Z obu wykresów wynika, że w krajach rozwiniętych mediana dochodów, mimo wzrostu PKB, w istocie nie rośnie a się stabilizuje. Dzieje się tak zarówno w Stanach Zjednoczonych, jak i w dziewiętnastu najbogatszych krajach Europy.

Interesujące wydaje się także to, że rozciąganie odchodowej struktury społeczeństwa nie występuje na całej długości rozkładu. Zmiany występują w drugiej jego połowie, a polegają na coraz większym przejmowaniu wolumenu dochodów przez najbogatszych. Jednocześnie to, co znajduje się w uboższej połowie, 
a więc poniżej mediany, pozostaje bez zmian. Można to zauważyć, porównując tabele 1 i 2.

Wykres 2. Wzrost dochodu w grupach dochodowych w krajach EU 19

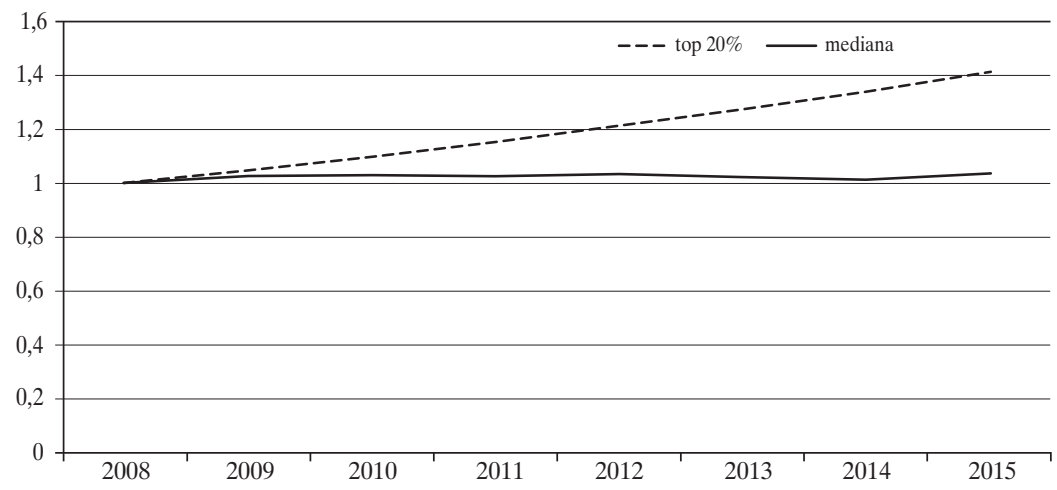

Źródło: opracowanie własne na podstawie: OECD Statistics, 2018.

Tabela 1. Udział 10\% najbogatszych w dochodach ogółem (w \%)

\begin{tabular}{|l|c|c|c|c|c|c|c|}
\hline \multicolumn{1}{|c|}{ Kraje } & $\mathbf{2 0 0 1}$ & $\mathbf{2 0 0 2}$ & $\mathbf{2 0 0 3}$ & $\mathbf{2 0 0 4}$ & $\mathbf{2 0 0 5}$ & $\mathbf{2 0 0 6}$ & $\mathbf{2 0 0 7}$ \\
\hline USA & $42.20 \%$ & $41.20 \%$ & $41.80 \%$ & $43.70 \%$ & $45.70 \%$ & $46.50 \%$ & $47.20 \%$ \\
\hline Francja & $34.50 \%$ & $35.10 \%$ & $34.50 \%$ & $35.30 \%$ & $34.50 \%$ & $34.90 \%$ & $35.60 \%$ \\
\hline Niemcy & $36.20 \%$ & $36.10 \%$ & $35.50 \%$ & $36.00 \%$ & $38.50 \%$ & $38.40 \%$ & $39.60 \%$ \\
\hline Włochy & $33.00 \%$ & $33.00 \%$ & $33.00 \%$ & $33.10 \%$ & $33.20 \%$ & $33.70 \%$ & $34.10 \%$ \\
\hline Japonia & $39.60 \%$ & $40.60 \%$ & $41.20 \%$ & $42.10 \%$ & $42.40 \%$ & $42.80 \%$ & $43.00 \%$ \\
\hline Holandia & $21.70 \%$ & $29.80 \%$ & $29.80 \%$ & $30.40 \%$ & $30.70 \%$ & $30.80 \%$ & $31.70 \%$ \\
\hline $\begin{array}{l}\text { Wlk. } \\
\text { Brytania }\end{array}$ & $41.40 \%$ & $41.00 \%$ & $41.40 \%$ & $40.80 \%$ & $41.60 \%$ & $42.00 \%$ & $42.60 \%$ \\
\hline Szwecja & $28.90 \%$ & $27.90 \%$ & $27.70 \%$ & $28.20 \%$ & $29.80 \%$ & $30.70 \%$ & $31.70 \%$ \\
\hline Szwajcaria & $31.90 \%$ & $31.20 \%$ & $31.30 \%$ & $31.60 \%$ & $31.90 \%$ & $32.60 \%$ & $33.30 \%$ \\
\hline & & & & & & & \\
\hline & $\mathbf{2 0 0 8}$ & $\mathbf{2 0 0 9}$ & $\mathbf{2 0 1 0}$ & $\mathbf{2 0 1 1}$ & $\mathbf{2 0 1 2}$ & $\mathbf{2 0 1 3}$ & $\mathbf{2 0 1 4}$ \\
\hline USA & $45.30 \%$ & $43.50 \%$ & $45.00 \%$ & $45.20 \%$ & $47.80 \%$ & $45.60 \%$ & $46.90 \% *$ \\
\hline Francja & $35.90 \%$ & $35.40 \%$ & $36.10 \%$ & $37.90 \%$ & $38.00 \%$ & $36.40 \%$ & $37.00 \%$ \\
\hline Niemcy & $40.00 \%$ & $39.80 \%$ & $39.70 \%$ & $39.00 \%$ & & & \\
\hline Włochy & $34.00 \%$ & $33.90 \%$ & & & & & \\
\hline Japonia & $42.30 \%$ & $41.30 \%$ & $41.60 \%$ & & & & \\
\hline
\end{tabular}

${ }^{*}$ W 2015 r. udział ten wynosił 50,5\%.

Źródło: Sverdlik, 2015. 
Tabela 2. Relacja piątego do pierwszych decyla rozkładu dochodów (P50/P10)

\begin{tabular}{|l|l|l|c|c|c|c|c|c|c|c|c|c|}
\hline & $\mathbf{2 0 0 2}$ & $\mathbf{2 0 0 3}$ & $\mathbf{2 0 0 4}$ & $\mathbf{2 0 0 5}$ & $\mathbf{2 0 0 6}$ & $\mathbf{2 0 0 7}$ & $\mathbf{2 0 0 8}$ & $\mathbf{2 0 0 9}$ & $\mathbf{2 0 1 0}$ & $\mathbf{2 0 1 1}$ & $\mathbf{2 0 1 2}$ & $\mathbf{2 0 1 3}$ \\
\hline USA & & & & 2.7 &.. &.. & 2.7 & 2.6 & 2.7 & 2.7 & 2.7 & \\
\hline Francja & & & & 1.8 &.. &.. & 1.8 & 1.8 & 1.9 & 1.9 & 1.9 & 1.9 \\
\hline Niemcy & & & & & & & 1.9 &.. &.. & 1.9 & 1.9 & 1.9 \\
\hline Włochy & & & & & & & & 2.6 &.. &.. & 2.6 & \\
\hline Japonia & & & & & & & & & 1.8 & 1.8 & 1.9 & 1.9 \\
\hline Holandia & & & & & & & & 1.8 & 1.8 & 1.9 & 1.9 & 1.9 \\
\hline $\begin{array}{l}\text { Wlk. } \\
\text { Brytania }\end{array}$ & 2.2 & 2.1 & 2.1 & 2.1 & 2.2 & 2.2 & 2.1 & 2.1 & 2.1 & 2 & 2 & 2 \\
\hline Szwecja & & & 1.7 &.. &.. &.. & 1.9 & 1.9 & 2 & 2 & & \\
\hline Szwajcaria & & & & & & & & 2 &.. & 2 & & \\
\hline
\end{tabular}

Źródło: jak tab. 1.

Choć dane dotyczące uboższej połowy społeczeństwa są bardzo niekompletne, nigdzie nie widać zmian relacji między decylami do poziomu mediany. Natomiast wzrost udziału najbogatszego decyla jest zjawiskiem powszechnym i znaczącym. Ma to ogromne znaczenie społeczne, jak również wywołuje skutki ekonomiczne, negatywne dla rozwoju ekonomicznego.

W teorii ekonomii to margines, jednak znaczna cześć społeczeństwa jest skłonna uznawać prawo Saya, niekoniecznie wiedząc, że takowe zostało sformułowane 150 lat temu. Mówi ono, że bogaci tworzą popyt, tak samo jak biedni. Każda jednostka pieniężna wydawana przez jej przedstawicieli ma więc taką samą siłę ssącą w stosunku do wytwarzanych produktów. Tak samo zatem tworzy miejsca pracy, rozwija technikę itp.

Otóż jest to po prostu nieprawda. Po pierwsze, bogaci mają większą skłonność do oszczędzania. Po drugie, popyt bogatych jest inny niż popyt osób biedniejszych. Nie tylko chodzi o różnicę w jakości dóbr, lecz także o wpływ wydatków tych grup na intensywność procesów produkcyjnych. Otóż popyt ludzi bogatych w coraz mniejszym stopniu kieruje się na dobra wytworzone w gospodarce. Dla tej grupy istnieją obecnie dwa obszary, gdzie istnieje największa dynamika wydatków. Pierwszy z nich to zakupy dóbr rzadkich. Od 10 lat mamy najwyższą stopę zwrotu na rynku funduszy inwestujących w dzieła sztuki. Wynosi ona $8 \%$ przy stopie wzrostu gospodarczego oscylującego wokół 0,5-1\% (Alindogan, 2015). Druga grupa to nieruchomości, a zainteresowanie nimi ilustruje wzrost wskaźnika cen mieszkań (wykres 3). 
Wykres 3. Indeks cen mieszkań w Europie

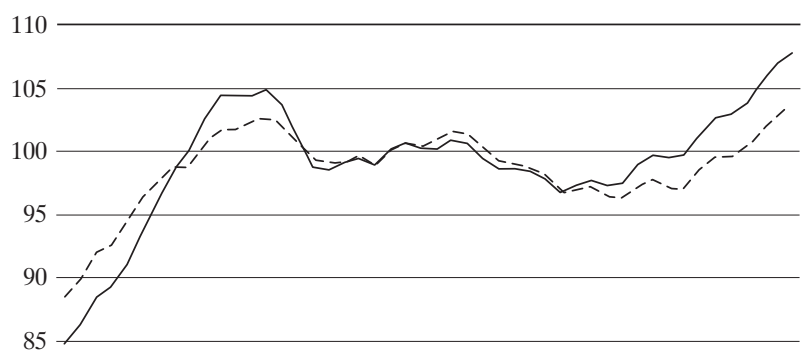

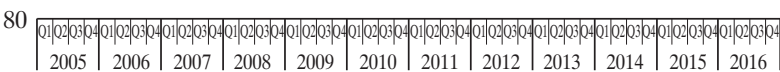
- EU - - Euro area

Źródło: Eurostat, 2016.

Wykres 4. Index cen mieszkań w USA. Dane kwartalne

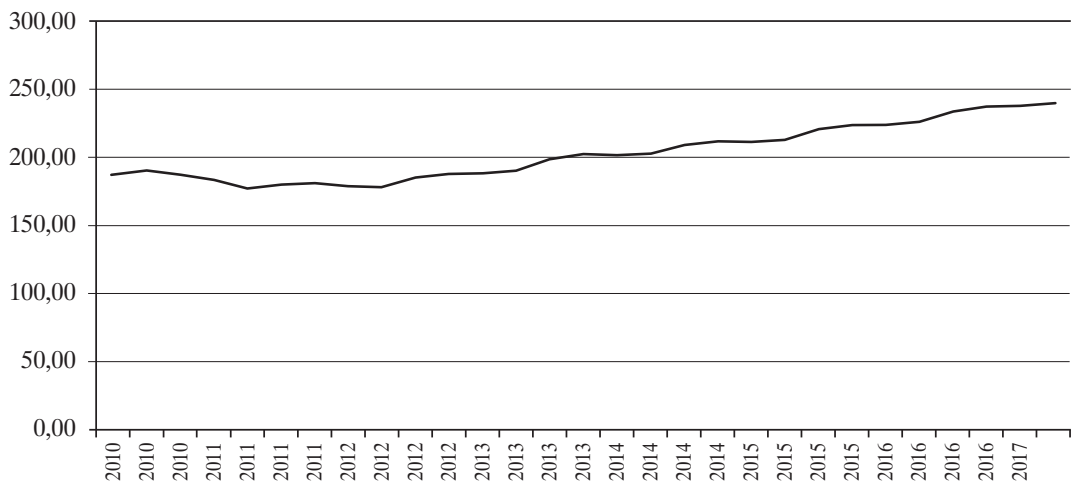

Źródło: Federal Housing Finance Agency. House Price Index Datasets. Purchase-Only Indexes (Estimated using Sales Price Data). Pozyskano z: https:/www.fhfa.gov/DataTools/Downloads/Pages/ House-Price-Index-Datasets.aspx.

W USA wzrost cen mieszkań jest nieco wolniejszy niż w Europie, jednak od 2012 roku systematycznie przekracza 5\% rocznie (wykres 4).

Kolejnym obszarem zasilanym przez najbogatsze percentyle są spekulacje. Ich obszar się powiększa, co nie jest obojętne dla gospodarki i to niekoniecznie z powodu możliwych bąbli cenowych. Przekonanie bowiem, że przy spekulacjach jedni wygrywają to, co drudzy przegrywają jest tylko częściową prawdą. Problem leży w tym, że spekulacje zasysają pieniądz. Według obliczeń autora sprzed trzech lat, ilość pieniądza zaabsorbowanego tylko przez obrót derywatami jest kwotą mniej więcej rzędu dochodu narodowego Niemiec (Sopoćko, 
2016). Wzrost tej kwoty wynosił wówczas mniej więcej 6-7\%. Można powiedzieć, że znaczna ilość pieniądza zasysana jest właściwie przez potrzeby samego obrotu.

\section{Zatrudnienie w epoce cyfryzacji}

Jak wspomniano, XXI wiek nie stał się bynajmniej okresem, w którym zaczęło brakować miejsc pracy. W epoce niebywałego przyspieszania automatyzacji po prostu zaczyna brakować pracowników i to nie tylko w określonych dziedzinach. Deficyt ma charakter ogólny, co pokazują obecne statystyki oraz prognozy na przyszłość.

Wykres 5. Stopa bezrobocia w USA po II wojnie światowej

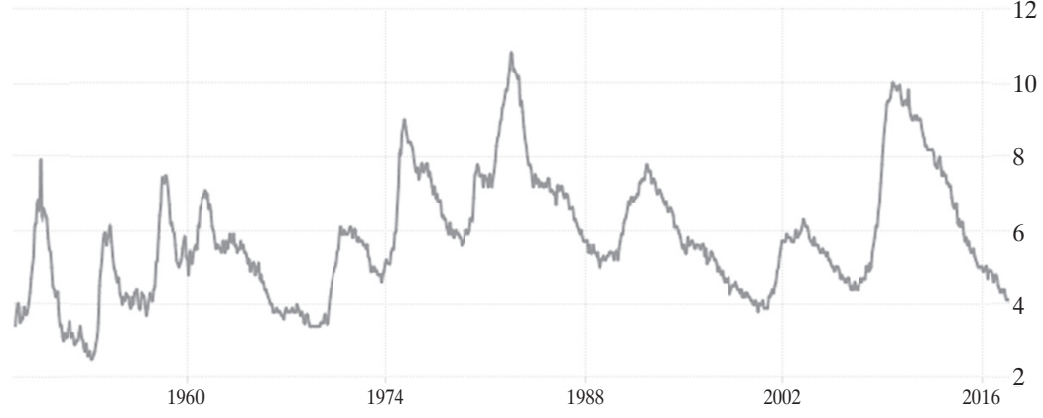

Źródło: TradingEconomist, 2018.

Brak związku spadku nowych miejsc pracy ze wskaźnikiem bezrobocia tłumaczy się dość prosto. Zasoby pracy we współczesnej, wysoko rozwiniętej gospodarce rosną (jako potencjał) dość wolno, co tłumaczy się starzeniem społeczeństwa. Potencjalnych pracowników przybywa, ale w znacznej części nie wskutek nowych urodzin, lecz wydłużenia długości życia. W dodatku takie rezerwy, jak możliwość wyższej aktywizacji zawodowej kobiet są praktycznie wyczerpane.

Przynajmniej w bliskiej perspektywie nie widać zagrożenia bezrobociem liczonym w wartościach absolutnych. U.S. Congressional Budget Office przewiduje przykładowo w roku 2020 osiągnięcie pełnego zatrudnienia, czyli likwidacji 
wartości bezrobocia do poziomu NAIRU (Non-Accelerating Inflation Rate of Unemployment). Oznacza to zlikwidowanie luki w zapotrzebowaniu na pracę, jaka powstała wskutek kryzysu subprime. W ten sposób w 2020 roku wartość PKB potencjalnego ma być taka sama jak rzeczywistego. Przyjmuje się bowiem w tym kraju, iż potencjał wzrostu praktycznie określony jest przez zatrudnienie - oczywiście do momentu, gdy przyrost zapotrzebowania na pracę zaczyna przyspieszać inflację.

Tabela 3. Wybrane poziomy i dynamika PKB w USA w bln USD, wg wartości z $2005 \mathrm{r}$.

\begin{tabular}{|l|c|c|c|}
\hline \multicolumn{1}{|c|}{ Typ PKB } & $\mathbf{2 0 1 0}$ & Projekt 2020 & Stopa wzrostu (w \%) \\
\hline Rzeczywisty & 13,0880 & 17,5129 & $3.0 \%$ \\
\hline Potencjalny & 14,0171 & 17,5129 & $2.3 \%$ \\
\hline
\end{tabular}

Źródło: Dubina, 2017.

$\mathrm{Z}$ tabeli 3 wynika, że przedstawiona projekcja zakłada całkowite wyjście $\mathrm{z}$ ekstremum dekoniunktury na początku następnego dziesięciolecia. Wiąże się to z wyższym wykorzystaniem zasobu pracy, który w początkowym okresie był istotnie poniżej stopy NAIRU. Tym samym, przy wykorzystaniu tej koniunkturalnej rezerwy, tempo wzrostu dochodu rzeczywistego wynosi więcej niż potencjalnego (o $0,7 \%$ ). Gdyby tej rezerwy nie było, przy utrzymaniu obecnej stopy inflacji PKB rosłoby o 2,3\% (Dubina, 2017).

Wykres 6. Stopa bezrobocia w EU

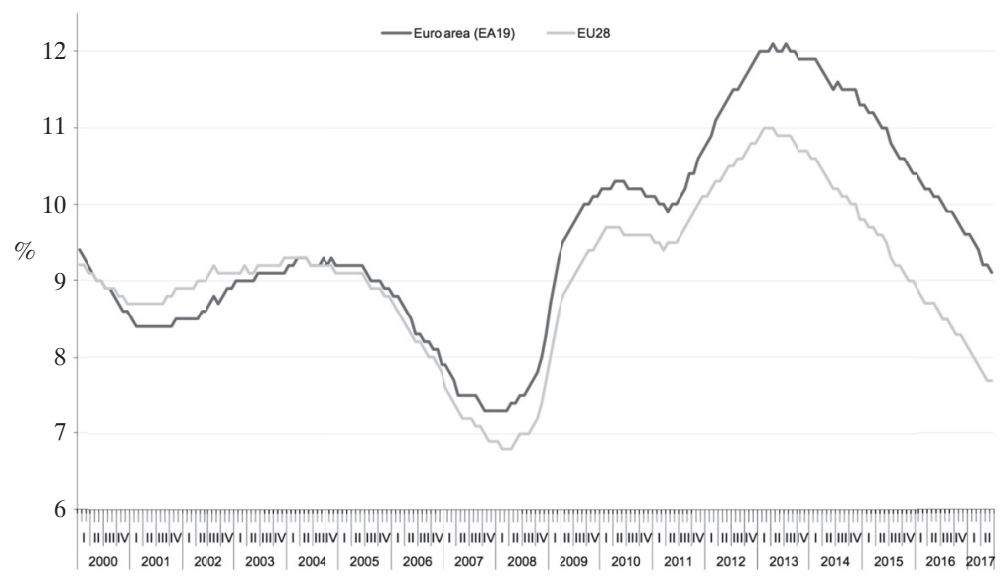

Źródło: Bowman, 2017. 
Przedstawiona projekcja dotyczy krótkiego okresu, co nie zmienia jednak jej wartości. Ma ona istotne znaczenie dla analiz przyszłości, ponieważ została przyjęta przez agencję rządową. Takie prognozy zwykle są podstawą dla działań rządu, muszą być więc dokonywane bardzo odpowiedzialnie. W tym przypadku można przyjąć, że rząd USA, opierając się na istniejących danych, nie przewiduje w najbliższym czasie wzrostu bezrobocia, jakie mogłoby powstać m.in. na skutek automatyzacji procesu pracy. Do podobnych wniosków można dojść, obserwując silny spadek tego wskaźnika w ubiegłym roku w Unii Europejskiej.

Japonia, gdzie bezrobocie tradycyjnie było na bardzo niskim poziomie, teraz pod tym względem bije rekordy. Dzieje się to w kraju o najwyższych osiągnieciach w dziedzinie konstrukcji robotów i automatyzacji procesów technologicznych.

Wykres 7. Bezrobocie w Japonii

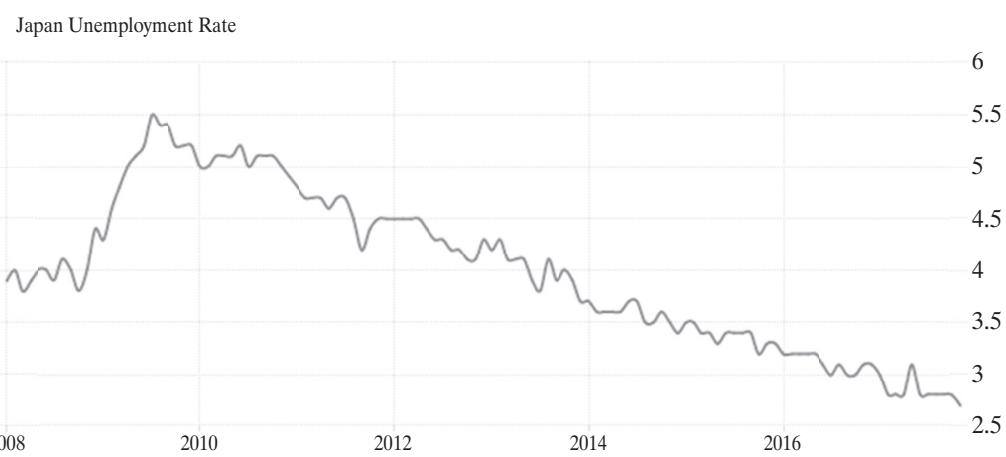

Źródło: Trading Economics, 2017.

Wspomniane dane empiryczne w żadnym stopniu nie potwierdzają tendencji do redukcji zatrudnienia wskutek rewolucji przemysłowej XXI wieku. Jednakże logika uruchomionych procesów zastępowania pracy nakazuje ostrożność. W perspektywie kilku, a może kilkunastu lat, trend może się odwrócić. Nie powinno się więc całkiem odrzucić scenariusza, w którym liczba ofert pracy ogółem ulegnie zmniejszeniu. Obecnie jednak brak ku temu tzw. twardych danych.

Na razie w gospodarce globalnej automatyzacji i cyfryzacji towarzyszy spadek bezrobocia (!), przy jednoczesnym wzroście liczby różnorakich ostrzeżeń o jego rychłym wzroście. Te ostatnie raczej nie maja charakteru systemowego, wywodzą się bardziej z obserwacji nowych produktów technologii. O ile bowiem wręcz daje się obliczyć ile miejsc pracy zastępuje automatyzacja, o tyle trudno 
oszacować ile (jednocześnie, bezpośrednio lub pośrednio) tworzy. Względnie łatwo można określić tendencje występujące w istniejących zawodach, ale prawie nie sposób określić przyrostu miejsc pracy wskutek zastosowania przełomowych wynalazków. Ilu ludzi trzeba będzie dla utrzymania infrastruktury i ochrony przed zakłóceniami autonomicznych pojazdów? Ilu ludzi znajdzie pracę przy kreowaniu i dystrybucji programów i urządzeń wirtualnej rzeczywistości itd.? $\mathrm{Na}$ razie nie sposób kompetentnie na te pytania odpowiedzieć.

Cyfryzacja i automatyzacja tworzy problemy, które trzeba będzie rozwiązywać przy pomocy wykwalifikowanych pracowników. Ważne jest przecież, by procesy te nie wymknęły się spod kontroli, by chronić system przed wirusami, atakami hackerskimi itp. Prawdopodobnie długo jeszcze będzie istniała potrzeba kreowania nowych programów komputerowych. Będzie więc praca dla programistów, ale również personelu niezbędnego dla serwisowania już istniejących, obrony przed ich hakowaniem itp.

Jak się wydaje, oceniając i analizując możliwe scenariusze zastosowania cyfryzacji i automatyzacji, należy odejść od podejścia określonego w pytaniu: co ona zastępuje? Te dwa zjawiska nie tyle bowiem zastępują jakieś elementy systemu wytwarzania, ile zmieniają cały system. A więc nie ograniczają się tylko do zastąpienia np. rutynowej, manualnej pracy. Takie podejście nie oddaje istoty zmian. Jak piszą Michael A. Osborne i Carl B. Frey (2013) „...kluczowym aspektem jest nie tyle posługiwanie się komputerami, ale szerokie zmiany w organizacji, które umożliwia technologia informatyczna. Najbardziej produktywne firmy reorganizują system decyzyjny, motywacyjny, przepływ informacji, naboru kadr oraz inne składowe organizacji, by uzyskać jak najwięcej z nowej technologii”. Dokonują się więc głębokie zmiany, w których jedne miejsca pracy znikają, inne się pojawiają. Jaki będzie bilans tych zmian - trudno przewidzieć. Zbyt dużo jest tu zmiennych, stopni swobody i luk informacyjnych. Nie znamy przecież ani wszystkich możliwości nowej techniki, ani granic jej adaptacji przez ludzi. Rysujący się aktualnie trend tworzenia miejsc pracy dzięki nowej technologii (a nie ich redukcji) ma też logiczne uzasadnienie. A są zdarzenia, które wywołują całe sekwencje zmian w dziedzinach towarzszących branżom, gdzie obserwuje się je bezpośrednio. Komputery jakieś czynności zastępują, ale powstaje wokół nich cała infrastruktura. Według wspomnianych autorów, 1 USD wydany na komputery wymaga 10 USD przeinaczonych na funkcjonowanie sieci, urządzeń peryferyjnych itp. Do tego potrzebni są wyspecjalizowani pracownicy.

Jak się okazuje, charakterystyczną cechą obecnych przemian w zatrudnieniu nie jest redukcja miejsc pracy, ale jego restrukturalizacja. W jednych obszarach zatrudnienie prawdopodobnie spadnie, w drugich - wzroście, bilans zmian wydaje się być jednak dodatni. W USA szacuje się, że mimo dość głębokich 
przesunięć w ofertach pracy przyszłość rysuje się dość optymistycznie. Oczekuje się bowiem wzrostu zatrudnienia, a nawet, że będzie ono szybsze niż do tej pory. O ile przyrost zatrudnienia w latach 2006-2016 wyniósł rocznie ok. 0,5\%, o tyle w następnej dekadzie prognozuje się $0,7 \%$, wobec $0,6 \%$ przyrostu zasobów siły roboczej (BLS News Relase, 2017). W następnym dziesięcioleciu miejsc pracy wydaje się więc przybywać więcej niż samej ilości osób w wieku produkcyjnym. W dodatku to wszystko będzie się odbywało w warunkach wysokiego wzrostu wydajności pracy. Ma on wg BLS wynosić 1,6\% rocznie w dziesięcioleciu 2017-2026, wobec istotnie słabszego $(1,2 \%)$ w dziesięcioleciu poprzednim (BLS News Relase, 2017). Według oficjalnych prognoz amerykańskich, nie oczekuje się więc w tym kraju zjawiska redukcji miejsc pracy przez automatyzację i sztuczną inteligencję. Podobnie sytuacja wygląda w strefie euro, gdzie przewiduje się spadek bezrobocia w tej dekadzie ${ }^{1}$.

Możliwe redukcję i zapotrzebowanie na pracę wskutek automatyzacji i cyfryzacji procesu można jako zilustrować jako rozejście się dwóch światów - rzeczywistego, gdzie najnowsze dane empiryczne nie wskazują na redukcję wolumenu miejsc pracy, a wręcz przyrost ofert oraz świadomości społecznej, w której pokutuje powszechne oczekiwanie, że automatyzacja i cyfryzacja zwiększy bezrobocie.

\subsection{Zmiany strukturalne}

Z danych Bureau of Labour and Statistics (BLS) wynika, że, z jednej strony, w 30 najbardziej zagrożonych zawodach do 2026 roku zostanie zlikwidowanych 11,5 mln miejsc pracy. Należą do nich m.in.: operatorzy lokomotyw, zegarmistrzowie, pracownicy call-centrów, sekretarki, pracownicy poczty, pracownicy powielarni itp. Średnie zarobki w tych zawodach mieszczą się w granicach 30-50 tys. USD rocznie ${ }^{2}$. Z drugiej zaś - oczekuje się znacznego przyrostu miejsc pracy w innych zawodach (zob. tab. 4).

Arwa Mahdawi w artykule z 26 stycznia 2017 roku pt. What jobs will still be around in 20 years? Read this to prepare your future wymienia pięć najbardziej zagrożonych przez automatyzację zawodów, w nawiasach szanse automatyzacji (Mahdawi, 2017): telemarkerzy (99\%), specjaliści od oceny wiarygodności kredytowej (98\%), personel kancelarii prawnych (98\%), kasjerzy (97\%), taksówkarze $(89 \%)$, kucharze fast-foodów (81\%). Najmniej zagrożeni są zaś: psycho-

1 EBC przewiduje, że w ciągu 5 lat w Eurostrefie bezrobocie zmniejszy się z obecnych (4 kw. 2017 r.) 9,1 do $7,9 \%$. Zob. ECB Unemployment rate forecast, w: European Central Bank, 2018.

2 Bureau of Labour and statistics. Employment projection. Table 1.5 Fastest declining occupations, 2016 and projected 2026, October 24, 2017. 
terapeuci $(0,3 \%)$, zajmujący się couchingiem $(35 \%)$, dietetycy $(0,39 \%)$, lekarze i chirurdzy $(0,42 \%)$ oraz duchowni $(0,81 \%)$.

Tabela 4. Spodziewane przyrosty zatrudnienia w wybranych zawodach w latach 2016-2026

\begin{tabular}{|l|c|}
\hline \multicolumn{1}{|c|}{ Zawód } & Przyrost zatrudnienia (w \%) \\
\hline Instalatorzy paneli fotowoltaicznych & 105.30 \\
\hline Serwisanci turbin wiatrowych & 96.10 \\
\hline Domowa pomoc medyczna & 46.70 \\
\hline Opieka osobista & 37.40 \\
\hline Asystenci medyczni & 36.00 \\
\hline Pielęgniarki & 33.40 \\
\hline Statystycy & 33.40 \\
\hline Terapeuci & 30.80 \\
\hline Programiści software & 30.50 \\
\hline Matematycy & 29.40 \\
\hline
\end{tabular}

Źródło: BLS News Relase, 2017.

Niektóre z tych pozycji są dość zaskakujące, jak analitycy bankowi czy personel kancelarii prawnych. Mało kto bowiem jest obecnie w stanie ogarnąć zakres powstałych aplikacji komputerowych. Niektóre z nich wyszły z etapu wyszukiwania, znajdowania koniunkcji, porównywania z zadanym wzorcem itp. Nadchodzi era samouczących się systemów, pozwalających na redagowanie pism procesowych czy szczegółową analizę pozycji i szans klienta na utrzymanie dochodów pozwalających spłacić dług. Zgodne natomiast $\mathrm{z}$ intuicją wydają się profesje uważane w tym artykule za w zasadzie niezagrożone. Nie znaleziono przecież dotąd sposobów, by komputery odczuwały empatię, były dobrymi doradcami w kwestiach estetycznych, reżyserowały filmy. Można bowiem skomputeryzować czynności, ale tą drogą trudno ukształtować osobowość elektronicznego partnera i uzyskać takie cechy jego działania, do których ludzie są przyzwyczajeni (poczucie humoru, nieschematyczność relacji, chęć zaciekawienia rozmówcy). Dlatego w tych zawodach, gdzie bezpośredni kontakt z człowiekiem jest punktem wyjścia dla odniesienia sukcesu biznesowego, automaty prawdopodobnie przejmą jedynie marginalną cześć wykonywanej pracy.

Automatyzacja i sztuczna inteligencja wydają się stosunkowo szybko opanować sferę wytwarzania dóbr, choć z pewnością na dłuższy czas pozostaną poza nią pewne obszary tej sfery (design, public relations, kreowanie działań promocyjnych). Tam będą przechodzili pracownicy, trzeba jednak pamiętać, że obszar, z którego mogą przejść, się kurczy. W przemyśle, gdzie robotyzacja 
zaznacza coraz bardziej swoją obecność, w krajach OECD pracuje obecnie tylko $22 \%$ zatrudnionych, 18\% w Wielkiej Brytanii, 17\% w Stanach Zjednoczonych. W Chinach, przemysłowym zagłębiu świata, zatrudnionych w przemyśle jest 22\% ogólu pracowników (World Bank, 2017).

W sferze usług automatyzacja dokonała i pewnie jeszcze dokona znacznych postępów, szczególnie w transporcie czy handlu. Jednak w pewnych obszarach usług można się spodziewać wręcz wzrostu zatrudnienia. Chodzi tu przede wszystkim o zawody wymagające kontaktów interpersonalnych. Bogacenie się górnych decyli dochodowych (o czym dalej w tekście) musi zwiększyć zapotrzebowanie na usługi w zakresie pielęgnacji ciała, rekreacji czy też usług wykonywanych zwykle przez domowników (sprzątanie). Trudno sobie wyobrazić roboty wykonujące manicure czy czyszczące porcelanę z Serves - to raczej pozostanie domeną ludzkich rąk.

Biorąc pod uwagę wszystkich pracujących, oczekiwane są istotne zmiany w strukturze zawodowej. Proces ten zaczął się jeszcze wcześniej, bo w latach dziewięćdziesiątych, kiedy automatyzacja i cyfrowe sterowanie pojawiły się na wielką skalę. W najbliższym dziesięcioleciu przewiduje się, że zmiany zawodu będzie musiało dokonać $14 \%$ populacji pracowników na świecie (2,6 mld osób). Największe potrzeby zmian wystąpią w krajach wysoko rozwiniętych: USA - co najmniej 32\%; Japonia - 46\%; Niemcy - 33\%. W sumie w krajach rozwiniętych przewiduje się, że zawody zmieni $1 / 3$ wszystkich pracujących, podczas gdy w krajach rozwijających się - ok. 9\% (Manyika, Lund, Chui i in., 2017, s. 11).

Te wielkości określają skalę stresu społecznego. Zmiana profilu zawodowego ze względów oczywistych wymaga sporego wysiłku (nowe kwalifikacje, wdrożenie się w nowe czynności, przestawienie percepcji na inne obszary). Jeśli jednak dotyczy znacznej części zatrudnionych (od jednej trzeciej do połowy), generuje poczucie zagrożenia dla wszystkich. $Z$ punktu widzenia relacji pracodawca - pracownik nie jest to dobra sytuacja dla tego ostatniego. Siła negocjacyjna, ale i sama motywacja do negocjowania warunków pracy i płacy, jest wówczas niska. Obawa o utrzymanie miejsca pracy w sytuacji, gdy zwalniana jest większa liczba osób ma psychologiczne uzasadnienie. Oznacza to, że będą bali się także ci, którzy w warunkach nowych technologii będą obiektywnie potrzebni. Przedstawione nieco dalej dane pokazują, że ogólnie o pracę nie będzie specjalnie trudno, w każdym razie nie trudniej niż obecnie. Samo jednak przejście $\mathrm{z}$ jednego miejsca pracy do drugiego nie musi być natychmiastowe. Kredyty jednak trzeba spłacać regularnie, podobnie jak płacić za mieszkanie. W jednym i drugim przypadku rysuje się rosnąca tendencja po stronie wydatków. Gospodarstwa domowe stają się coraz bardzie zadłużone, a czynsze, wraz ze wzrostem cen nieruchomości, także idą w górę. 
W perspektywie przynajmniej jednego pokolenia nie wydaje się by sytuacja społeczna uległa w tym zakresie zmianie, jak na razie obecne trendy są bardzo silne. Narastanie dysproporcji płacowych wyraźnie wystąpiło w przeprowadzonej przez autora ekonometrycznej analizie procesu stratyfikacji wynagrodzeń (Jaworski i Sopoćko, 2017). Dane z lat 2002-2015 wskazują, że wzrost dochodu narodowego powoduje bardzo szybkie bogacenie się górnych decyli struktury dochodowej, natomiast stagnację, a nawet spadek dochodów w biedniejszej części społeczeństwa. Obliczone na odstawie danych OECD Statistic wskaźniki elastyczności dochodu względem PKB wskazują, że mediana dochodów ludności nie nadąża za wzrostem dochodu narodowego. Wartość $\beta \mathrm{w}$ równaniach regresji dla poszczególnych krajów wynosi zawsze poniżej jedności, a czasem jest ujemna (Wielka Brytania - 0,92; Niemcy - 0,691; Francja - 0,831; USA - 0,995; Włochy - minus 0,472; Holandia - minus 0,631; Japonia - minus $\left.0,341^{3}\right)$. Z kolei elastyczność dochodów najwyższego decyla w stosunku do PKB wynosi we wszystkich badanych krajach powyżej jedności, a czasem powyżej dwu (Niemcy - 2,148; Francja - 1,365; Wielka Brytania - 1,298; USA - 2,336; Włochy - 1,034; Holandia - 1,466; Japonia - 1,8434).

Dane te dla Europy, wobec stosunkowo niskiego wzrostu PKB, oznaczają praktycznie stagnację dochodów uboższej części społeczeństwa. W Stanach Zjednoczonych tempo wzrostu PKB było wyższe niż w Europie i Japonii, jednak nie do końca można uznać je za zjawisko pozytywne, ponieważ wiązał się z tym wzrost dysproporcji dochodowych. Mediana dochodów w tym kraju przez 15 lat XXI wieku była niższa niż z końca ostatniego dziesięciolecia wieku XX5.

W tych warunkach ocena rynku pracy w najbliższych 10 latach, uważanych za okres ekspansji automatyzacji i cyfrowego sterowania, nie wypada jednoznacznie. Bezrobocie w krajach rozwiniętych wykazuje tendencję spadkową, ale korzyści z tego nie odnosi bynajmniej większość społeczeństwa. Bogaci bogacą się coraz szybciej, połowa społeczeństwa pozostaje zaś na stabilnym poziomie dochodów realnych. Pożytki ze wzrostu wydajności pracy raczej jej nie dotyczą. Nowa rewolucja techniczna ma tu swój wkład. Prognozę dynamiki płac w Stanach Zjednoczonych dla poszczególnych decyli ich struktury prezentuje wykres 8 .

Test istotności dla tego parametru funkcji regresji wyniósł powyżej 0,9 .

Wartości parametrów obliczone przy współczynniku ufności przekraczającym 0,95.

Zob. Tabela A-2. Selected Measures of Household Income Dispersion: 1967 to 2015 (Wybrane mierniki dochodu gospodarstw domowych), w: United State Census Bureau, 2017. 
Wykres 8. Oczekiwane tempo wzrostu płac (w \%) w poszczególnych decylach placowych w USA w latach 2016-2030

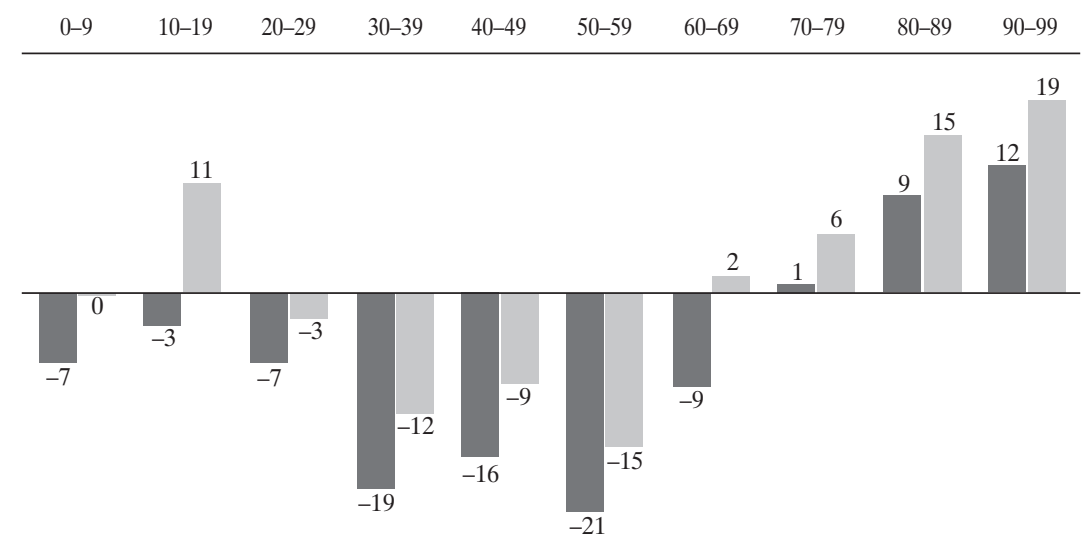

Źródło. Manyika, Lund, Chui, Bughin, Woetzel, Batra, Ko i Sanghvi, 2017, s. 89.

Na wykresie 8 widać wspomniane zjawisko spadku dochodów w środkowych grupach, wobec $w$ istocie ich stabilizacji (sumarycznie) w grupie $1 / 3$ najuboższych. Zdecydowanie wysoki wzrost jest przewidywany w grupie najlepiej zarabiających. W Niemczech przewiduje się stabilizację w 2/3 ogółu ludności, podzielonej według dochodów, wzrost w najlepiej zarabiającej trzeciej tercji. W Japonii przewiduje się w ogólny spadek dochodów realnych, największy jednak w grupie środkowej, najmniejszy zaś - wśród najlepiej zagrabiających (Manyika, Lund, Chui i in., 2017, s. 88).

Ze względu na różnice w systemach opieki socjalnej i redystrybucji dochodów wnioskowanie co do siły zmian ich struktury w krajach rozwiniętych musi być ostrożne. Jednak teza o pogorszeniu się sytuacji klasy średniej w okresie przemian, które według przewidywań mają się dokonać w okresie następnego pokolenia, ma obecnie racjonalne i empiryczne podstawy.

\section{Podsumowanie}

Przemiany społeczne wydają się obecnie zmierzać ku dwubiegunowemu społeczeństwu, czyli takiemu, w którym istnieje grupa bogatych i reszta, bynajmniej nie uboga, jednak oddzielona od tej pierwszej istotnym przedziałem dochodów. Oznacza to redukcję klasy średniej (w statystycznym ujęciu), która w odróżnieniu od poprzednich epok staje się coraz mniej znacząca dla rozwoju cywiliza- 
cyjnego. Główną siłą sprawczą tego procesu jest trwająca obecnie rewolucja cyfryzacji i automatyzacji. Nie redukuje ona, wbrew niedawnym oczekiwaniom, liczby miejsc pracy. Wywołuje jednak głęboką restrukturalizację zatrudnienia, która nieproporcjonalnie wysoko wynagradza osoby o dużych predyspozycjach intelektualnych, znacznej wiedzy i specjalistycznych kwalifikacjach. Inni są też potrzebni, ale w tej grupie latwo jest zastąpić jednych drugimi. Natomiast na stanowiskach o wysokich wymaganiach ten zabieg jest znacznie trudniejszy, przez co utrzymuje się tu wysokie płace. Możliwość odejścia tego typu pracowników wywołuje zagrożenie destabilizacji procesu wytwarzania, naturalne w przypadku wypadnięcia fachowców kluczowych dla funkcjonowania fabryk i systemów świadczenia usług.

Niewątpliwie wspomniana rewolucja przyczynia się do zwiększania wolumenu społecznego dobrobytu, tyle że korzystają z tego przede wszystkim najwyższe decyle dochodowe. Rodzi to lukę nie tylko w poziomie indywidualnej konsumpcji, lecz także w dostępie do świadczeń społecznych, w szczególności zdrowotnych i edukacyjnych. Tam, gdzie są one odpłatne, stają się barierą w migracji między warstwami społecznymi, a wzorzec społeczeństwa równych szans przesuwa się coraz bardziej w sferę iluzji. W krajach, gdzie dostęp do tych świadczeń jest powszechny, zagrożenia dwubiegunowością rozwoju społecznego wydają się mniejsze, choć raczej nie zanikną. Wysokie różnice w poziomie życia przyczyniają się także do innych zjawisk, jak nierówności w dysponowaniu majątkiem, w tym także produkcyjnym, co ma dalsze istotne konsekwencje społeczne.

\section{Bibliografia}

Acemoglu, D. i Robinson, J. (2013). Why Nation Fail. The origins of Power, Prosperity and Powerty. London: Profile Books Ltd. (s. 73-75).

Alindogan, M. (2015). Van Gogh's painting sells for \$66M, nearly six times its 2003 price. AOL News, 6 maja. Pozyskano z: http://www.aol.com/article/2015/05/06/van-gogh-s-paintingsells-for-66m-nearly-six-times-its-2003-pr/21180474/.

Allen, R.C. (2009). Engels' pause: Technical change, capital accumulation, and inequalityin the british industrial revolution. Explorations in Economic History. https://doi.org/10.1016/j. eeh.2009.04.004. Pozyskano z: https://www.nuff.ox.ac.uk/Users/Allen/engelspause.pdf

BLS News Relase. (2017). Employment projections 2016-26. U.S. Department of Labor, 24 października. Pozyskano z: https://www.bls.gov/news.release/pdf/ecopro.pdf.

Bowman R. (2017). Unemployment in the Eurozone has fallen to its lowest level since 2009. World Economic Forum, 3 sierpnia. Pozyskano z: https://www.weforum.org/agenda/2017/08/unemployment-falls-optimism-rises-in-eu/.

Brynjolfsson, E. i McAfee, A. (2011). Why Workers Are Losing the War Against Machines. The Atlantic, October 26. 
Brynjolfsson, E. i McAfee, A. (2014). The Second Machine Age. Work, Progress, and Prosperity in a Time of Brilliant Technologies. Nowy Jork: W.W. Norton \& Company.

Deloitte. (2016). Art \& Finance Report 2016. Luksemburg: Deloitte, ARTTactic. Pozyskano z: https://www2.deloitte.com/content/dam/Deloitte/at/Documents/finance/art-and-financereport2016.pdf.

Dubina, K.S. (2017). Full employment: an assumption within BLS projections. Monthly Labor Review. U.S. Bureau of Labor Statistics, November, https://doi.org/10.21916/mlr.2017.30. Pozyskano z: https://www.bls.gov/opub/mlr/2017/article/full-employment-an-assumptionwithin-bls-projections.htm.

Employment protection. (2017). U.S. Bureau of Labor Statistics. Pozyskano z: https://www. bls.gov/emp/tables/emp-by-detailed-occupation.htm (24.10.2017).

European Central Bank. (2018). ECB staff macroeconomic projections for the euro area. March. Pozyskano z: https://www.ecb.europa.eu/pub/pdf/other/ecb.ecbstaffprojections201803.en.pdf.

Eurostat. (2016). House Price Statistic _ House Price Index. Pozyskano z: https://ec.europa. eu/eurostat/statistics-explained/index.php/Housing_price_statistics_-_house_price_index euro area and EU aggregates Index levels 2010100 2016Q4.PNG.

Jaworski, P. i Sopoćko, A. (2017). Impact of income distribution on the economic growth. Referat przedstawiony na konferencji Oxford University i Bilbao University, 28-29 czerwca.

Kelso, L.O. i Hetter, P. (1967). Two-Factor Theory. The Economics Of Reality: How to Turn Eighty Million Workers into Capitalists on Borrowed Money and Other Proposals. Nowy Jork: Random Hause.

Kurland, N.G. (2001). A New Look at Prices and Money: The Kelsonian Binary Model for Achieving Rapid Growth Without Inflation. The Journal of Socio-Economics, 30(6), 495-515. https://doi.org/10.1016/S1053-5357(01)00121-4. Pozyskano z: https://www. researchgate.net/publication/4932117_A_New_Look_at_Prices_and_Money_The_Kelsonian_Binary_Model_for_Achieving_Rapid_Growth_Without_Inflation.

Mahdawi, A. (2017). What jobs will still be around in 20 years? Read this to prepare your future. The Guardian, June 26. Pozyskano z: https://www.theguardian.com/us-news/2017/ jun/26/jobs-future-automation-robots-skills-creative-health.

Majid, N. (2010). On the Income Dimension of Employment in Developing Countries. Employment Sector. Employment Working Paper No. 72. International Labour Office. Geneva. Pozyskano z: http://www.ilo.org/wcmsp5/groups/public/---ed_emp/---emp_elm/--analysis/documents/publication/wcms_151802.pdf.

Manyika, J., Lund, S., Chui, M., Bughin, J., Woetzel, J., Batra, P., Ko, R. i Sanghvi, S. (2017). Jobs Lost, Jobs Gained: Workforce Transitions In A Time Of Automation. McKinsey Global Institute, December. Pozyskano z: https://www.mckinsey.com/ /media/McKinsey/ Featured $\% 20$ Insights/Future $\% 20$ of $\% 20$ Organizations/What $\% 20$ the $\% 20$ future $\% 20$ of $\% 20$ work $\% 20$ will $\% 20$ mean $\% 20$ for $\% 20$ jobs $\% 20$ skills $\% 20$ and $\% 20$ wages/MGI-Jobs-Lost-JobsGained-Report-December-6-2017.ashx.

Osborne, M.A. i Frey, C.B. (2013). The Future of Employment: How Susceptible Are Jobs to Computerisation?. Oxford Martin School, University of Oxford, Working Paper, September 17.

OECD Statistics. (2018). Income Distribution and Powerty. Pozyskano z: https://stats.oecd. org/Index.aspx?DataSetCode $=$ IDD.

Piketty, T. (2015). Kapitat w XXI wieku. Warszawa: Wydawnictwo Krytyki Politycznej. 
Prasad, E., Rajan, R. i Subramanian, A. (2007). The Paradox of Capital. Finance \& Development. A quarterly magazine of the IMF, 44(1).

Rotman, D. (2013). How Technology Is Destroying Jobs. MIT Technology Review, June 12. Pozyskano z: https://www.technologyreview.com/s/515926/how-technology-is-destroyingjobs/.

Rzońca, A. (2014). Kryzys Banków centralnych. Skutki stopy procentowej bliskiej zera. Warszawa: C.H. Beck.

Saez, E. i Zucman, G. (2014). Wealth Inequality in the United States since 1913: Evidence from Capitalized Income Tax Data. NBER Working Paper 20625, October.

Sopoćko, A. (2015). Mit pieniądza. Realna gospodarka wobec iluzji polityki monetarnej. Warszawa: PWN.

Sopoćko, A. (2016). Polityka emisji pieniądza procesie zrównoważonego wzrostu. W: J. Kleer, K. Prandecki (red.), Ekonomiczna pozycja Europy w świecie. Warszawa: Komitet Prognoz „Polska 2000 Plus”.

Spannagel, D. (2015). Trotz Aufschwung: Einkommensungleichheit geht nicht zurück. WSIVerteilungsbericht 2015. WSI-Mitteilungen, 8. Pozyskano z: https://www.boeckler.de/wsimitteilungen_62503_62548.htm.

Statista. (2018). Number of full-time Alphabet employees from 2007 to 2017. The Statistics Portal. Pozyskano z: https://www.statista.com/statistics/273744/number-of-full-timegoogle-employees/.

Stierli, M., Shorrocks, A., Davies, J.B., Lluberas, R. i Koutsoukis, A. (2015). Global Wealth Report 2015. Zurich: CREDIT SUISSE AG Research Institute, October. Pozyskano z: http://publications.credit-suisse.com/tasks/render/file/index.cfm?fileid=F2425415-DCA780B8-EAD989AF9341D47E.

Sverdlik, Y. (2015). Iowa Officials Approve Tax Breaks for Google Data Center Expansion. Knowledge \& Networking Division of Informa PLC, Data Center Knowledge, 17 kwietnia. Pozyskano z: http://www.datacenterknowledge.com/archives/2015/04/17/iowa-officialsapprove-tax-breaks-for-google-data-center-expansion.

Tomkiewicz, J. (2017). Dynamika i struktura dochodów w warunkach globalizacji. Warszawa: PWN.

Trading Economics. (2017). Pozyskano z: https://tradingeconomics.com/japan/unemploymentrate, 26 December.

Trading Economist. (2018). Pozyskano z: https://tradingeconomics.com/united-states/unemployment-rate, 3 August.

United State Census Bureau. (2017). Table A-2. Selected Measures of Household Income Dispersion: 1967 to 2015. Pozyskano z: https://www2.census.gov/programs-surveys/demo/ tables/p60/256/table4.xls.

U.S. Bureau of Economic Analysis. (2018). Real Gross Domestic Product [GDPC1]. FRED, Federal Reserve Bank of St. Louis, September 3. Pozyskano z: https://fred.stlouisfed. org/series/GDPC1.

Walker S. (2017). Unequal Russia: is anger stirring in the global capital of inequality? The Guardian, 25 kwietnia. Pozyskano z: https:/www.theguardian.com/inequality/2017/apr/25/ unequal-russia-is-anger-stirring-in-the-global-capital-of-inequality.

World Bank. (2017). Employment in industry (\% of total employment). Pozyskano z: https:// data.worldbank.org/indicator/SL.IND.EMPL.ZS?view= chart 


\section{Kontrola kapitału przeciw pułapce średniego dochodu}

Kraje rozwijające się i obecnie znacznie już zaawansowane w rozwoju, do których zalicza się Polska mają niższą produktywność czynników wytwórczych, w tym wydajności pracy. Wśród przyczyn ważne znaczenie ma niekorzystny dla nich podział pracy w światowym łańcuchu tworzenia wartości. Ważną przyczyną takiego stanu w krajach postsocjalistycznych była przyspieszona prywatyzacja, głównie z udziałem kapitału zagranicznego, a także struktura zagranicznych inwestycji bezpośrednich. W gospodarce narodowej dominują zagraniczne korporacje, które lokowały w tych krajach pracochłonne procesy produkcji, korzystając z taniej siły roboczej. Podrzędną rolę miejscowej produkcji wzmocnił proces globalizacji. Mogą one znaleźć się w pułapce średniego rozwoju, a obecnie funkcjonują w swoistej niższej lidze gospodarki światowej. Podrzędna rola miejscowych podwykonawców wynika z tego, że nie partycypują oni we własności kapitałowej firm i tym samym mają mały wpływ na władzę międzynarodowych korporacji. Poprawa ich pozycji wymaga aktywnej polityki państw, w tym również w zakresie kontroli struktury przepływu kapitału w ujęciu brutto.

Słowa kluczowe: transformacja, globalizacja, inwestycje zagraniczne, międzynarodowe korporacje, kontrola kapitału, międzynarodowy łańcuch tworzenia wartości.

\section{Wprowadzenie}

Polskiej gospodarce grozi spowolnienie tempa wzrostu z powodu wygasania czynników dających jej przewagę komparatywną w stosunku do wysoko rozwiniętych partnerów gospodarczych i handlowych, ponieważ wystąpią skutki niekorzystnego podziału pracy, który przypadł Polsce w międzynarodowym łańcuchu tworzenia wartości towarów i usług. O korzystnej pozycji zajmowanej w tym łańcuchu przesądza kapitał, który daje władzę w dominujących korporacjach międzynarodowych. Poprawa tej pozycji wymaga zaś bardziej skutecznego zarządzania kapitałem.

Polska, stanowiąca małą gospodarkę otwartą, osiągnęła w ostatnim ćwierćwieczu, po transformacji ustrojowej, wydatny postęp gospodarczy. Wysokie tempo wzrostu ułatwiały znaczne zasoby dobrze wykształconej i taniej siły roboczej, przyuczonej do produkcji w warunkach uprzemysłowienia, w procesie nieefektywnej tzw. industrializacji socjalistycznej. Zasoby ludzkie pozostawały 
dostępne dla inwestorów miejscowych i zagranicznych, w kraju w znacznym stopniu zurbanizowanym. Można dodać, że miało też znaczenie korzystne położenie geograficzne Polski, w bliskim sąsiedztwie Unii Europejskiej.

Transformacja ustrojowa na początku lat 90 . ubiegłego wieku przyniosła radykalne zmiany w gospodarce polskiej nazwane „terapią szokową”. Przyśpieszona prywatyzacja w ramach „terapii szokowej” sprawiła, że podstawowe zakłady produkcyjne $\mathrm{z}$ braku kapitału rodzimego zostały przejęte przez kapitał zagraniczny. Stworzone też zostały atrakcyjne warunki dla zachęty do bezpośrednich inwestycji zagranicznych (BIZ). Inwestorzy zagraniczni wykorzystali tę zachętę, tj. przede wszystkim tanią siłę roboczą, przenosząc pracochłonne procesy produkcyjne do Polski. Prywatyzacja była niekiedy w istocie sprzedażą segmentu rynku, prywatyzowane przedsiębiorstwo wkrótce zostawało zamknięte, a jego miejsce na rynku krajowym zajmował zagraniczny producent. Czasem jednak zakład przechodził restrukturyzację i modernizację, stając się wykonawcą produkcji zlecanej przez nowego właściciela. W tej fazie rozwoju polskiej gospodarki dawało to jednak wzrost produktywności, wydajności pracy i w efekcie korzyści obu stronom: zagranicznym właścicielom - zarządcom i krajowym wykonawcom. Był to więc offshoring korzystny dla obu stron. Z powodu braku rodzimego kapitału alternatywą zagranicznych inwestorów mogłoby być tzw. uwłaszczenie - niestety z realną groźbą oligarchizacji gospodarki, jak u wschodnich sąsiadów kraju.

W łańcuchu tworzenia wartości przedsiębiorstwo znajdowało się na dole łańcucha tej krzywej opisywanego „krzywą uśmiechu”, w którym najwyższą marżę wartości dodanej uzyskują firmy ulokowane na początku i na końcu łańcucha. $\mathrm{Na}$ obu podniesionych jego krańcach tworzą bowiem cenę produktu i wartość dodaną właściciele kapitału, twórcy marki producenta, projektanci, organizatorzy łańcucha kooperacji produkcji, zarządzający tym łańcuchem i specjaliści marketingu. Niżej będą usługi dla biznesu: księgowe. finansowe, prawne, logistyczne inne, a po środku krzywej, najniżej - działalność fabryczna. Działalność najbardziej profitującą, umieszczoną na krańcach krzywej, nazwę skromnie: zarządzaniem.

Niestety owo zarządzanie procesowe nie jest polską specjalnością w międzynarodowym podziale pracy. O tej uprzywilejowanej lokacie decyduje właśnie własność kapitału i dzięki temu władza, a ta należy do akcjonariuszy i podległych im menedżerów zarządzających korporacją, nawet jeśli ci ostatni rekrutują się spośród rezydentów. Kapitał, jak wiadomo, nie ma ojczyzny, natomiast akcjonariusze ją mają lub nawet często sobie ją wybrali w rajach podatkowych.

Rozbudzona aktywność przedsiębiorcza społeczeństwa w nowych warunkach ustrojowych, a jedocześnie znaczny napływ kapitału, prywatyzacja przez wykup 
przedsiębiorstw państwowych przez zagranicznych inwestorów oraz nowe inwestycje bezpośrednie z zagranicy sprawiły, że Polska została włączona gwałtownie w proces globalizacji gospodarki światowej, osiągając ewidentne korzyści, jak też, niestety, została narażona na pewne ograniczenia czy wręcz zagrożenia, które uwidoczniły się z czasem.

Globalizacja, globalne rynki utrwaliły więc tę samą pozycję zarówno dla producentów krajowych, jak i inwestorów zagranicznych inwestujących w Polsce - podrzędne miejsce w łańcuchu tworzenia wartości produktów i usług. Były to nadal role: kooperanta, podwykonawcy czy wykonawcy produktów finalnych, zlecanych przez międzynarodowe korporacje. Nie było to jednak w ówczesnym stanie polskiej gospodarki zupełnie niekorzystne.

Bezpośrednie inwestycje zagraniczne przyczyniły się wydatnie do wzrostu zatrudnienia i wydajności pracy, lecz nie były przełomem w zakresie upowszechnienia nowych technologii, ponieważ stanowiły przeniesienie części procesów produkcyjnych. Ten charakter inwestycji dobrze ilustruje ich wydajność mierzona wartością dodaną według poszczególnych branż, w których te inwestycje były lokowane. Efekty bezpośrednich inwestycji zagranicznych (FDJ) mierzone udziałem w tworzeniu Produktu Krajowego Brutto w Polsce badała platforma wiedzy „Polityka Insight”. Część tych wyników zawiera tabela 1 .

Tabela 1. Udział FDI w wybranych branżach w nakładach i rezultatach

\begin{tabular}{|l|c|c|}
\hline & $\begin{array}{c}\text { Struktura branżowa napływu } \\
\text { inwestycji zagranicznych (FDJ) }\end{array}$ & $\begin{array}{c}\text { Udział branż we wzroście PKB } \\
\text { dzięki tym inwestycją (FDJ) }\end{array}$ \\
\hline $\begin{array}{l}\text { Przetwórstwo } \\
\text { przemysłowe }\end{array}$ & $32 \%$ & $17 \%$ \\
\hline Budownictwo & $4 \%$ & $6 \%$ \\
\hline Handel & $16 \%$ & $19 \%$ \\
\hline Pozostałe usługi & $52 \%$ & $68 \%$ \\
\hline
\end{tabular}

Źródło: Czerniak i Blauth, 2017.

Choć zagraniczne inwestycje przynosily do Polski nowe technologie, to jednak były one z obszaru produkcji przetwórczej, przynoszącej stosunkowo mały wzrost wartości dodanej w działalności przemysłowej i budowlanej, wyższy natomiast w handlu, a zwłaszcza w pozostałych usługach. Natomiast o wiele ważniejszym rezultatem był ich wpływ na rozszerzenie możliwości eksportu, co miało duże znaczenie dla poprawy bilansu płatniczego kraju.

Otwarcie gospodarki na procesy globalizacji przynosiło także nowe doświadczenia organizacyjne $\mathrm{w}$ dziedzinie międzynarodowych relacji gospodarczych 
i handlowych ${ }^{1}$, a także szeroki dostęp do kapitału, dostęp do rynków zagranicznych i wzrost eksportu. Rosła też wydajność pracy i wynagrodzenia, gospodarka Polski skracała dystans rozwojowy do krajów wyżej rozwiniętych. Zasadność w tych okolicznościach przyjęcia instytucji wykształconych w Europie przez Polskę podkreśla Dani Rodrik (2011). Przeprowadzone reformy i dobry stan finansów państwa pozwoliły również spełnić kryteria przystąpienia Polski do Unii Europejskiej w 2004 roku. Wspólny rynek unijny stał się kolejnym impulsem rozwojowym. Postępował proces konwergencji realnej, wzmacniany dodatkowo przez solidarnościowe fundusze unijne. Kryzys gospodarki światowej z lat 2008-2009 tylko spowolnił tempo wzrostu, lecz nie przerwał procesu konwergencji. Również obecne ożywienie czy wręcz dobra koniunktura w gospodarce światowej pozwalają nadal podtrzymać ten proces lecz - jak się wydaje - nie na długo. Rola podwykonawcy nieuchronnie da o sobie znać. Proces konwergencji realnej ustanie. Kraj może wpaść w pułapkę średniego dochodu. Ten termin, choć powszechnie używany, określający sytuację danego kraju, w przypadku sytuacji polskiej gospodarki nie jest - moim zdaniem - odpowiedni. Lepiej tu skorzystać z terminologii sportowej: kraj pozostaje na trwałe graczem niższej ligi gospodarki światowej, z niewielką szansą awansu do ekstraklasy. Może się rozwijać, lecz nie osiągnie poziomu PKB liczonego na 1 mieszkańca, a zatem i dobrobytu obywateli krajów wysoko rozwiniętych. Główną przyczyną jest właśnie ta niższa produktywność pracy, wynikająca z mniej korzystnego miejsca w łańcuchu tworzenia wartości (GWC). Nie jest to bowiem dobry podział pracy między równymi partnerami, bo też partnerzy nie są równi. Nie sposób tu stosować zasady korzyści komparatywnych Davida Ricardo, ponieważ gospodarka światowa jest odmienna od tej sprzed dwóch wieków. Postulat, by każdy robił to, co potrafi najlepiej i najtaniej przestaje być słuszny w warunkach stwarzanych przez globalizację, gdy wszyscy robią ten sam produkt finalny, wykonując tylko różne czynności w różnych krajach².

1 Rodrik zwraca uwagę na to, że Polska, podobnie jak inne kraje Europy, przeszła podobną drogę historyczną. Naśladowanie instytucji, które zostały w Europie stworzone mogły być przydatne w warunkach polskich (Rodrik, 2011).

2 Np. Francuzi lansują modne sukienki i organizują produkcję, mieszkańcy Azji Wschodniej tkają i szyją, a Polacy prowadzą księgowość, magazynują i transportują. Wszyscy pracują w tym bynajmniej nie najnowocześniejszym sektorze gospodarki, lecz wnoszą różną wartość dodaną, co owocuje różnym wynagrodzeniem i różnym poziomem partycypacji w tworzeniu PKB. 


\section{Pułapka czy druga liga?}

Tempo wzrostu gospodarczego w Polsce jest w dalszym ciągu wyższe niż w sąsiadujących krajach wysokorozwiniętych, a ostatnio osiąga nawet 4-5\% rocznie, gdy u sąsiadów stopa wzrostu jest o połowę niższa. Może powstać pytanie, skąd ta obawa o przyszłość polskiej gospodarki o ustanie procesu konwergencji realnej. Niepokój wynika z kilku powodów.

Zawansowanie w rozwoju gospodarczym Polski sprawia, że niebezpieczeństwo pułapki średniego dochodu jest póki co mało prawdopodobne. Poziom PKB $\mathrm{w}$ przeliczeniu na jednego mieszkańca według parytetu siły nabywczej stanowi nieco ponad 50\% PKB najbogatszego sąsiada - Niemiec i około 70\% analogicznego poziomu 19 krajów „starej” Unii Europejskiej. Polsce bliżej do krajów rozwiniętych niż większości emerging markets. W przeglądzie literatury światowej na temat pułapki średniego poziomu rozwoju Andrzej Wojtyna (2016, s. 8) stwierdza, że „definicje 'pułapki' można podzielić na te o charakterze jakościowo-deskryptywnym oraz te o charakterze ilościowym. W przypadku tych pierwszych często zwraca się uwagę na trudności w przesuwaniu się krajów na średnim poziomie rozwoju w górę międzynarodowego łańcucha wartości. W tym ujęciu bariery wzrostu mają przede wszystkim charakter mikroekonomiczny w związku z czym ich przezwyciężenie wymaga zastosowania określonych narzędzi polityki przemysłowej”. W tego typu pułapce, w niższej lidze gospodarki światowej może znaleźć się Polska. W tym przypadku tradycyjna polityka przemysłowa, lub szerzej - sektorowa, już nie wystarczy. Powstaje więc pytanie, czy w poszukiwaniu sposobu przeciwdziałania w przypadku takiej postaci pułapki średniego poziomu rozwoju można wykorzystać metodę Nowej Ekonomii Strukturalnej (NES) sformułowanej przez J.Y. Lina (Lin i Nowak, 2018). Samo promowanie sektorów o wyższej wartości dodanej, w tym przypadku już nie przyniesie pożądanych rezultatów, ponieważ poszczególne sektory, w tym również tego typu, w kraju już istnieją, lecz miejsce krajowych producentów w tych sektorach jest niekorzystne, podrzędne. Wynika to ze struktury własności i wspomnianej funkcji zarządzania łańcuchem tworzenia wartości w poszczególnych korporacjach. W tych warunkach chodzi więc o wykorzystanie instrumentów zarządzania przepływem kapitału, aby uniknąć niebezpieczeństw pozostania na trwałe w „drugiej lidze” krajów zaawansowanych w rozwoju, skazanych na niższą produktywność pracy i tym samym niższą marżę wartości dodanej w przeliczeniu na zatrudnionego. Ten stan to niekorzystny rezultat $\mathrm{w}$ istocie pożądanej, lecz pośpiesznej prywatyzacji i również pożądanych, choć nie zawsze spełniających oczekiwania gospodarzy, zagranicznych inwestycji bezpośrednich (BIZ). 
Pomyślny rozwój gospodarczy partnerów handlowych Polski, zwłaszcza krajów Unii Europejskiej sprzyja wzrostowi gospodarczemu również krajów pozostających w owej niższej lidze gospodarki europejskiej. Krzywa produktywności w kształcie „krzywej uśmiechu” może się nawet wygładzać w kierunku prostej. Po pierwsze - dlatego, że zwiększa się udział w tworzeniu PKB wyżej wycenianych usług w porównaniu $\mathrm{z}$ działalnością fabryczną, w tym zwłaszcza usług dla biznesu. Mogą również wzrastać i rzeczywiście wzrastają wynagrodzenia w działalności produkcyjnej oraz w usługach, zarówno w następstwie wzrostu poziomu kwalifikacji pracowników, lepszego wyposażenia technicznego miejsc pracy, jak i w następstwie sytuacji na rynku pracy. Wyczerpują się bowiem zasoby taniej siły roboczej w tym jednak przypadku pojawia się także zagrożenie, o czym niżej.

Po drugie - w polskiej gospodarce dużą rolę odgrywają małe i średnie przedsiębiorstwa w tym również przedsiębiorstwa rodzinne. Przedsiębiorstwa te zarządzane są oczywiście przez miejscowych przedsiębiorców, co powinno sprzyjać wyższej produktywności wynikającej z pozycji własności i władzy. Jednak skala prowadzonej działalności w ramach tych przedsiębiorstw jest niewielka, a więc w rezultacie również i produktywność jest niższa niż w przypadku firm wchodzących w skład wielkich korporacji. Rozwój takich przedsiębiorstw musi jednak sprostać konkurencji na rynku zdominowanym przez wielkie korporacje. Jeśli tego typu przedsiębiorstwa nie zostaną zdominowane przez konkurencję, czy też przez nią wykupione, to w rezultacie ich działalności następować będzie również wygładzenie krzywej produktywności. Z kolei wszystkie inne małe i średnie przedsiębiorstwa wraz z wyczerpywaniem się zasobów siły roboczej będą między sobą konkurować o pozyskanie pracowników, co spowoduje również wzrost kosztów pracy, wymuszając zmiany organizacji pracy i inwestycje na rzecz wzrostu wydajności pracy także w tym sektorze. Takie działania w efekcie łącznym przyczynią się też do wzrostu wartości dodanej. Niestety taki bieg zdarzeń może okazać się nazbyt optymistyczny.

Wzrost wynagrodzeń to utrata ważnego elementu przewagi konkurencyjnej. To przecież niższe koszty pracy sprzyjały przenoszeniu do Polski pracochłonnych procesów produkcji oraz szeregu usług w tym również biznesowych. Międzynarodowe korporacje mogą ten rodzaj działalności przenosić do krajów tańszych rąk do pracy. Tak więc outsourcing, który służył polskiej gospodarce w poprzednim stanie niskich płac i bezrobocia, w początkach budowy gospodarki rynkowej, teraz może stać się zagrożeniem, jeśli pozostawi po sobie pogorszenie pozycji przetargowej pracowników czy wręcz bezrobocie.

Po trzecie - dla krajów rozwijających się oraz krajów znacznie zaawansowanych w rozwoju goszczących jednak w niżej lidze gospodarki światowej poja- 
wia się niestety nowe zagrożenie wynikające $\mathrm{z}$ nowej rewolucji przemysłowej nazywanej „Przemysłem Generacji 4.0. Choć postęp techniczny związany z tą generacją jest przyjmowany z entuzjazmem, to jednak kraje, które nie nadążaja za przesuwającą się w górę granicą wysokich technologii mogą wiele stracić. Wynika to nie tylko $\mathrm{z}$ następstw $\mathrm{w}$ postaci zaniku konwergencji realnej, lecz także może spowodować dywergencję, pogłębienie różnic w poziomie rozwoju (Ryć, 2017). Offshoring procesów produkcji z krajów o wysokich kosztach pracy może zamienić się $\mathrm{w}$ reshoring, ponieważ $\mathrm{w}$ wyniku cyfryzacji produkcji, inteligentnych fabryk oszczędzających ludzką pracę i tym samym jej koszty przywraca opłacalność. Powrót przetwórstwa przemysłowego do krajów macierzystych międzynarodowych korporacji spowoduje powstanie poważnych problemów dla krajów słabiej rozwiniętych (Götz, 2018).

Jest więc wystarczająco dużo powodów, aby kraje mniej zaawansowane w rozwoju podjęły wysiłki na rzecz opuszczenia owej drugiej ligi.

\section{Zarządzanie strukturą przepływu kapitału dla pożądanych efektów w skali mikroekonomicznej}

Panuje powszechna opinia, że drogą do osiągnięcia wysokiej produktywności są innowacje i przedsiębiorczość. Innowacje tworzy kapitał ludzki i społeczny, na który składają się też instytucje sprzyjające innowacyjności. Tworzenie kapitału ludzkiego wymaga nakładów finansowych na badania naukowe i kształcenie kadr. Niezbędne jest też publiczne wspieranie inkubacji przedsiębiorczości i aktywna w tej dziedzinie rola państwa.

Protegowanie rozwoju gospodarczego przez państwo sprawdziło się w przeszłości w przypadku krajów dziś wysoko rozwiniętych. Również zdało egzamin w wielu gospodarkach dawniej ubogich zwłaszcza w Azji Wschodniej i Południowo-Wschodniej obecnie wysoko rozwiniętych lub znacznie zaawansowanych w rozwoju. Tego typu protekcjonizm jest wykluczony w przypadku Polski - członka Unii Europejskiej - kraju, który po transformacji ustrojowej wkroczył z sukcesem na drogę liberalnej gospodarki rynkowej, choć jest narażony na przedstawione wcześniej zagrożenie pozostania w statusie podwykonawcy.

Postulat postawienia na innowacje, ich tworzenie, formowanie kapitału ludzkiego i społecznego jest oczywisty. Nakłady kapitałowe na ten cel są uzasadnione. Nie ma jednak gwarancji, że dzięki nim wyrosną w kraju potęgi technologiczne generujące wysoką wartość dodaną. Powodem tego są niesprzyjające warunki „hodowli” takich championów, jakie stwarza wolny rynek, a tym bar- 
dziej wspólny rynek europejski. Można co najwyżej liczyć na odosobnione przypadki, ponieważ swobodny przepływ kapitału i wolny rynek temu nie sprzyjają. Swoją opinię, która odnosi się do typu emerging market, ale także do Polski najbardziej dobitnie wyraził J.S. Stiglitz (2010, s. 258) „Liberalizacja handlu oznaczała, że zagraniczne firmy mogły „wyżynać w pień” raczkujące miejscowe branże, tłamsząc rozwój przedsiębiorczych talentów. Gdy kapitał przepływał swobodnie, przepływ siły roboczej był ograniczony $-\mathrm{z}$ wyjątkiem najbardziej utalentowanych jednostek, z których wiele znajdowało dobre zatrudnienie na globalnym rynku pracy”. Te ostre słowa noblisty odnoszą się również do doli wielu inicjatyw i karier wybitnych jednostek w Polsce. Nie są natomiast usprawiedliwieniem dla polskich lamentów nad odpływem zysków za granicę od międzynarodowych korporacji, które zainwestowały w Polsce. Do tego mają prawo i powinniśmy pozostać im życzliwi za to, co uczynili, tworząc miejsca pracy i za to, co pozostawiają w Polsce w postaci wynagrodzeń pracowniczych $-\mathrm{z}$ reguły wyższych od tych rodzimych w małych i średnich przedsiębiorstwach oraz zapłaconych u nas podatków. Nie znaczy to bynajmniej rezygnacji z osłony i ze wspierania rodzimych konkurentów również za pomocą środków kapitałowych, tym bardziej przez skuteczne zarządzanie strukturą przepływu kapitału. A więc nie chodzi o zmianę reguł gry, lecz o skuteczniejsza grę o wejście przez rodzimy kapitał na pozycję zarządzania w coraz większej części liczących się producentów i świadczeniodawców usług. Wypracowanie metod i narzędzi operowania kapitałem w tym kształtowaniem struktury kapitału w skali mikroekonomicznej wspierającym politykę przemysłową wydaje się zadaniem możliwym w założeniach Nowej Ekonomii Strukturalnej.

W tym miejscu można wskazać kilka kierunków oddziaływania za pomocą środków kapitałowych.

1. Na pierwszym miejscu należy postawić to, co prawie wszyscy badacze uważają za istotne, a mianowicie na nakłady finansowe na wzrost kapitału ludzkiego i społecznego. Chodzi o to by zdolnych ludzi kształcić, a wykształconych nie tracić, badania finansować, lecz ich wyników, które mogą być zaczynem innowacji nie eksportować w surowej postaci. Nie jest to więc zadanie prostego powiększania środków na ten cel, lecz ich przemyślanej struktury zabezpieczającej uzyskanie pożytku z zainwestowanego kapitału. Struktura angażowanych środków winna nie tylko maksymalizować wzrost, lecz także minimalizować ubytek i straty tego kapitału.

2. Należy ostrożnie podchodzić do państwowej „hodowli” championów. Co było możliwe w Azji Wschodniej, nie jest do powtórzenia w Europie Środkowej i we wspólnym rynku. Przykładowo, w Polsce postawienie na elektromobilność w przemyśle samochodów osobowych, bez rodzimych innowacji, nie ma 
praktycznie wielkich szans na wyjście poza wykonawstwo i montaż. Technologicznie zaawansowane komponenty będą zakupywane za granicą nawet wtedy, gdy zagraniczni producenci zechcą je wytwarzać w Polsce. To oni właśnie znajdują się w korzystnej pozycji wnikającej z ich własności i władzy. Nie znaczy to, że podobnych prób nie należy całkowicie wykluczyć, lecz nie można wzorem reguł „starej” Ekonomii Strukturalnej, która m.in. dopuszczała produkcję antyimportową - na nich budować korzystnej pozycji w łańcuchu tworzenia wartości ${ }^{3}$ (Lin i Nowak, 2018).

3. Kontrola struktury dopływu i odpływu kapitału: wspieranie outsursingu do Polski przedsięwzięć innowacyjnych zgłaszających popyt na pracę wykwalifikowaną, dobrze wynagradzaną oraz na usługi dla biznesu. $Z$ rezerwą natomiast trzeba się odnosić do przenoszenia prostej produkcji, jeśli ona nie ułatwia rozwiązywania, np. lokalnych problemów rynku pracy.

4. Udomowienie zagranicznego kapitału przez tworzenie korzystnych warunków dla wprowadzania przez nie nowych technologii, reinwestowania zysków. Co prawda nie można obecnie liczyć na współczesnych Wedli, Moteli czy Bliklich, zagranicznych przedsiębiorców i inwestorów, którzy w Polsce osiedli i od pokoleń prowadzili tu swój biznes. Zapewne za przyczyną choćby większej mobilności społecznej trwała rezydencja zagranicznych współwłaścicieli czy właścicieli jest mniej prawdopodobna.

5. Możliwy jest wykup przez rodzimy kapitał niepubliczny w całości lub też udziałów w zagranicznych przedsiębiorstwach działających w kraju. Nie chodzi tu o repolonizację, czyli wykup przez spółki państwowe, lecz przede wszystkim rodzimy sektor prywatny wraz z jego umocnieniem na rynku kapitałowym.

6. Pogłębienie usług finansowych nie tylko dla małych i średnich przedsiębiorstw oraz poczatkujących producentów, lecz także dla ambitnych przedsięwzięć kapitałowych polskich producentów w kraju i za granicą.

7. Celowy offshoring - Polska dotychczas korzystała i nadal korzysta z przenoszenia do nas produkcji zagranicznych firm. Dziś obawiamy się ich ucieczki do miejsc o tańszej sile roboczej. Jednak stosunkowo mały jest offshoring polskich firm do krajów o niższych kosztach produkcji. Teraz i w przyszłości należy na większą skalę korzystać z tej metody i przenosić mniej wydajną produkcję poza granice naszego kraju. Oczywiście pod warunkiem, że nie grozi to wzrostem bezrobocia. Tego typu działania polskich przedsiębiorców należy mocniej wspierać.

3 Polskie przedsiębiorstwo, które z sukcesem wytwarzało autobusy z napędem elektrycznym, również $\mathrm{z}$ sukcesem je eksportowało zostało wystawione na sprzedaż i zapewne trafi w ręce zagranicznych inwestorów. 


\section{Podsumowanie}

Proces dochodzenia do korzystnej pozycji w międzynarodowym łańcuchu tworzenia wartości, za pomocą aktywnej polityki kontroli przepływu kapitału, nie jest bynajmniej pewny ani tym bardziej krótki. Wysiłki w tej dziedzinie należy podejmować, ponieważ pozostawanie kraju w owej niższej lidze gospodarki światowej nie tylko nie satysfakcjonuje społeczeństwa, lecz także jest niebezpieczne. Grozi bowiem wpadnięciem w autentyczną pułapkę średniego poziomu rozwoju.

\section{Bibliografia}

Czerniak, A. i Blauth, K. (2017). Co przyniosty inwestycje zagraniczne. Warszawa: Polityka Insight.

Götz, M. (2018). Przemysł czwartej generacji (przemysł 4.0) a międzynarodowa współpraca gospodarcza. Ekoomista, (4), 385-403.

Lin, Y.J. i Nowak, Z.A. (2018). New structural economics for less advanced countries. Warszawa: Wydawnictwo Wydziału Zarządzania Uniwersytetu Warszawskiego.

Rodrik, D. (2011). Jedna ekonomia wiele recept. Warszawa: Krytyka Polityczna.

Ryć, K. (2017). The expiring real convergence process under conditions of the common market - how to counteract. W: Y.J. Lin, A.Z. Nowak, New structural economics for less advanced countries (s. 69-79). Warszawa: Wydawnictwo Naukowe Wydziału Zarządzania Uniwersytetu Warszawskiego.

Stiglitz, J.E. (2010). Freefall. Warszawa: Polskie Towarzystwo Ekonomiczne.

Wojtyna, A. (2016). Standardowe i niestandardowe działania antykryzysowe. Gospodarka Narodowa, (6). 5-22. 
CZĘŚĆ II 



\title{
Państwo wspierające a rozwój gospodarczy: rola państwa w Nowej Ekonomii Strukturalnej ${ }^{1}$
}

\begin{abstract}
Artykuł analizuje koncepcje rozwoju i roli państwa w rozwoju gospodarczym oraz ich wpływ na przemiany instytucjonalne z punktu widzenia Nowej Ekonomii Strukturalnej. Wysunięto tezę, że struktury ekonomiczne - włącznie ze strukturą techniki i przemysłu oraz infrastruktury twardej i miękkiej - mają charakter endogeniczny względem struktury uposażenia, która jest dana w każdej konkretnej chwili i zmienna w czasie. Opowiedziano się za rolą państwa w zakresie ułatwiania przemian strukturalnych poprzez wykorzystanie polityki przemysłowej do naprawiania niedomagań rynku. Działania takie winny wspomagać branże przemysłu cechujące się ukrytymi przewagami komparatywnymi i ułatwiać im zyskanie konkurencyjności na rynku. Państwo winno wykorzystywać swoje ograniczone zasoby i zdolności wdrożeniowe w sposób pragmatyczny, przyznając priorytet tworzeniu enklaw o korzystnej infrastrukturze $i$ rozwijaniu instytucji, aby pobudzać dynamiczny wzrost $w$ krajach o zasadniczo ubogiej zastanej infrastrukturze i sieci instytucjonalnej.
\end{abstract}

Słowa kluczowe: rola państwa, rozwój gospodarczy, Nowa Ekonomia Strukturalna.

\section{Wprowadzenie}

Po drugiej wojnie światowej wiele krajów uzyskało polityczną niezależność i weszło na ścieżkę modernizacji. W odpowiedzi na potrzebę budowania państwa w krajach rozwijających się wyłoniła się nowa poddyscyplina współczesnej ekonomii: ekonomia rozwoju. Spodziewano się, że będzie ona przeprowadzać te kraje przez proces industrializacji i pomoże im w osiagnnięciu dobrobytu.

Wyniki jednak rozczarowują, ponieważ wśród prawie 200 rozwijających się gospodarek jedynie Korea Południowa i Tajwan (Republika Chińska) zdołały podnieść swój status do państwa o wysokim dochodzie (Lin i Rosenblatt, 2014)2 a wśród 110 gospodarek o średnich dochodach w latach 60. XX wieku tylko

1 Opublikowano w: Man and the Economy, 4(2), grudzień, 2017, s. 1-19.

2 Chiny kontynentalne mogą stać się trzecią gospodarką, która zmieni status z państwa o niskich na państwo o wysokich dochodach około roku 2025. 
trzynaście zmieniło status na gospodarki o wysokim dochodzie (Agenor i in., 2012). Z tych trzynastu gospodarek osiem było zaś albo krajami ościennymi Europy Zachodniej, w których dystans do krajów rozwiniętych był niewielki już na starcie, albo krajami produkującymi ropę. Pozostałe pięć to Japonia, Korea, Tajwan, Hongkong i Singapur.

Nowatorski model wzrostu Solowa prognozuje konwergencję dochodów, zgodnie z którą kraje ubogie powinny rozwijać się szybciej niż bogate z powodu zjawiska malejących przychodów z kapitału (Solow, 1956). Niemniej, pomimo wysiłków podejmowanych przez kraje rozwijające się oraz wielostronnej pomocy wielu agencji rozwoju, większość z tych gospodarek nie dogoniła gospodarek o wysokich dochodach, co warto przeanalizować.

Mankiw i in. (1992) argumentują, że rozszerzony model Solowa, obejmujący gromadzenie kapitału ludzkiego i fizycznego, stanowi doskonały opis danych występujący między krajami. Zgodnie z zasadą, podobną jak w wypadku kapitału fizycznego, niższy poziom kapitału ludzkiego powinien oznaczać wyższą stopę zwrotu. Jednakże biedne kraje nie są w stanie zgromadzić wystarczającej ilości kapitału ludzkiego z powodu deficytu inwestycji w wysokiej jakości edukację, a także znacznych problemów z „drenażem umysłów”. Problem ten porównywany jest do zjawiska ucieczki kapitału z krajów ubogich do zamożnych (Lucas, 1990). Zatem mniejsze kapitały fizyczny i ludzki muszą wynikać $\mathrm{z}$ bardziej fundamentalnego zjawiska, które leży u podstaw niepowodzenia rozwojowego.

Jak twierdzi Kuznets (1966), obecnie wzrost dochodów ma charakter procesu nieprzerwanych transformacji strukturalnych z ciągłymi innowacjami technologicznymi $\mathrm{w}$ istniejących branżach oraz $\mathrm{z}$ pojawianiem się nowych branż o wyższej wartości dodanej, które podnoszą produktywność pracy i ulepszeń infrastruktury - zarówno ciężkiej, czyli materialnej, jak i miękkiej, czyli niematerialnej, w tym instytucjonalnej. Wszystkie te innowacje i ulepszenia obniżaja koszty transakcyjne gospodarki. Ponieważ kraje rozwijające się są stosunkowo zacofane pod względem technologii i przemysłu, powinny mieć większy potencjał wzrostu niż kraje rozwinięte i osiągać konwergencję z uwagi na łatwość podnoszenia poziomu swoich technologii i przemysłu (Gerschenkron, 1962). Jednakże od czasu drugiej wojny światowej większość krajów rozwijających się nie wykorzystała tych możliwości i utknęła w segmencie państw o dochodach niskich lub średnich.

Argumentuje się, że skuteczne i sprawne instytucje są kluczem do wzrostu gospodarczego i że to właśnie rozwój tych instytucji w Europie Zachodniej przyczynił się do ukształtowania nowoczesnego Zachodu (zob. North i Thomas, 
1976; North, 1990; Acemoglu i Robinson, 2012). Powszechnie przyjmuje się także, że instytucje są oporne na zmiany i jest mało prawdopodobne, aby źle funkcjonujące instytucje w danym kraju uległy samoczynnej naprawie (North, 1990; Acemoglu i in., 2001). Kraje, które posiadają sprawniejsze instytucje, bezpieczniejsze prawo własności i mniej wypaczoną politykę będą również więcej inwestowały w kapitał fizyczny i ludzki. Będą wykorzystywały te czynniki efektywniej dla osiągnięcia wyższego poziomu dochodów (Acemoglu i in., 2001). Jednak czy w krajach, w których niewydolne instytucje hamują wzrost gospodarczy istnieje sposób, aby je zreformować i rozwinąć gospodarkę - zmienić bieg historii zamiast cofać się w czasie?

Jak powiedział Keynes (1935, s. 384), „to idee, a nie konkretne interesy stanowią groźną broń w służbie dobra lub zła”. W artykule tym postawiono tezę, że słabe postępy w rozwoju większości krajów rozwijających się wynikają z niewłaściwych pomysłów na ścieżkę rozwoju i rolę państwa. Niniejszy artykuł omawia koncepcje rozwoju i rolę państwa w rozwoju gospodarczym i zmianach instytucjonalnych z perspektywy Nowej Ekonomii Strukturalnej (Lin, 2011; 2012).

Zdaniem autorów niniejszego artykułu, państwo wspiera rozwój gospodarczy poprzez przezwyciężanie nieodłącznych nieprawidłowości w funkcjonowaniu rynku, związanych z przemianami technologicznymi, modernizacją przemysłu i ulepszeniami infrastruktury twardej i miękkiej. Nieprawidłowości takie wynikają z różnych efektów zewnętrznych, z roli pierwszych graczy oraz z problemów $\mathrm{z}$ koordynacją, jakie pojawiają się $\mathrm{w}$ procesie poprawy twardej infrastruktury i instytucji w ramach transformacji strukturalnej.

Dynamiczny rozwój gospodarki wymaga organicznego związku między rynkiem a państwem, który polega na tym, że rynek jest wydajny tylko wtedy, gdy państwo ułatwia przezwyciężanie nieprawidłowości w działaniu rynku, a czyni to w celu zapewnienia wydajności rynku. Stwierdzono również, że jeżeli zasadnicze koncepcje są prawidłowe, to państwo rozwijające się - bez względu na to czy jest silne, czy słabe - może w sposób pragmatyczny podejmować i realizować politykę pobudzającą dynamiczny wzrost, pomimo istniejących niedomagań w postaci słabo rozwiniętej infrastruktury i instytucji. Nie wysunięto postulatu zwiększenia zakresu kontroli państwa nad rynkiem ani pogłębiania interwencjonizmu. Stwierdzono jedynie, że ułatwiająca rola państwa jest koniecznym warunkiem rozwoju i jedynie posiadanie i realizacja właściwych pomysłów pozwalają krajom rozwijającym się na pobudzenie i utrzymanie dynamicznego wzrostu gospodarczego.

Artykuł ma na celu zaprezentowanie nowej teorii państw ułatwiających rozwój gospodarczy. W pierwszej kolejności omówiono wcześniejsze koncepcje ekonomii rozwoju z naciskiem na ich poglądy na temat roli państwa. Następnie 
przedstawiono główne idee Nowej Ekonomii Strukturalnej i z jej perspektywy przedstawiono rolę państwa.

\section{Poprzednie generacje ekonomii rozwoju ${ }^{3}$}

\subsection{Ekonomia rozwoju 1.0: strukturalizm}

Pierwszą generacją ekonomii rozwoju był strukturalizm. Po drugiej wojnie światowej wiele krajów rozwijających się dążyło do zapewnienia swoim obywatelom takiego standardu życia, jaki zdobyły społeczeństwa świata rozwiniętego. Warunkiem realizacji tego celu było osiągnięcie w kraju rozwijającym się takiego samego dochodu i wydajności pracy, jak w krajach rozwiniętych. To z kolei wymagało posiadania równie zaawansowanego przemysłu, tymczasem rzeczywistość krajów rozwijających się była inna - dominowały w nich tradycyjne rolnictwo i eksploatacja zasobów naturalnych.

$\mathrm{Na}$ ambicję stworzenia zaawansowanego przemysłu w krajach rozwijających się równie silnie wpływało pogorszenie warunków wymiany handlowej między eksporterami surowców a importerami produktów przemysłowych w latach 30. i 40. XX wieku od czasu Wielkiego Kryzysu. Przywódcy polityczni i elity społeczne w wielu krajach Ameryki Lacińskiej dostrzegały nieustanny spadek cen dóbr eksportowanych (produktów podstawowych, surowców) i trwałe pogarszanie się ich stosunku do cen dóbr importowanych. Zjawisko to powodowało przepływ dochodów z bogatych w zasoby krajów rozwijających się do bogatych w kapitał krajów rozwiniętych. W tej sytuacji uznano, że pomysłem na uniknięcie takiego wykorzystywania krajów rozwijających się przez kraje rozwinięte będzie zapewnienie warunków do krajowej produkcji przemysłowej poprzez stopniową substytucję importu. Jednocześnie, przemianie byłych kolonii lub półkolonii w nowe niepodległe państwa w Azji i na Bliskim Wschodzie, a później także w Afryce, towarzyszyły silne nastroje nacjonalistyczne.

$\mathrm{Z}$ punktu widzenia strukturalizmu kraje rozwijające się nie mogły zbudować nowoczesnego przemysłu, ponieważ na przeszkodzie stały istniejące sztywne struktury państwowe, które osłabiały działanie rynku i uniemożliwiały samoczynny rozwój przemysłowy. Strukturalizm opowiada się za państwem rozwojowym i zaleca rządom krajów rozwijających się przyjęcie strategii substytucji importu wraz z odpowiednią polityką cenową i mobilizacją na rzecz rozwijania zaawansowanego, nowoczesnego przemysłu. Podejście takie było również

3 Ta część nawiązuje do: Lin, 2011; Lin i Rosenblatt, 2012. 
zgodne z dominującą w tym okresie doktryną interwencjonizmu państwowego Keynesa. Realizując strategię substytucji importu, wiele krajów rozwijających się przeżywało okres inwestycyjnego wzrostu, choć przerywanego okresami zastoju i częstych kryzysów. Zjawiska te dodatkowo zwiększyły różnicę w dochodach krajów rozwiniętych i rozwijających się.

\subsection{Ekonomia rozwoju 2.0: neoliberalizm}

O ile realizowane przez rządy strategie rozwoju gospodarczego oparte na strukturalizmie poniosły porażkę $\mathrm{w}$ wielu krajach, o tyle doktryna wolnego rynku zdawała się triumfować i wpływać na myślenie o rozwoju. Dominująca keynesowska makroekonomia została zakwestionowana w okresie stagflacji lat 70., kryzysu zadłużeniowego Ameryki Łacińskiej oraz upadku socjalistycznego systemu planowania w latach 80 . Pojawiła się wówczas tzw. rewolucja racjonalnych oczekiwań, która obaliła podstawy teoretyczne strukturalizmu dotyczące roli państwa i jego polityki fiskalnej oraz pieniężnej w rozwoju gospodarczym.

W latach 80. pojawił się natomiast neoliberalizm. Trend ten interwencje rządu uznawał za główną przyczynę niepowodzenia krajów rozwijających się w doganianiu krajów rozwiniętych, a w ich miejsce zalecał zestaw wytycznych polityki neoliberalnej wspierany konsensusem waszyngtońskim. Miało to eliminować interwencję rządu w procesy gospodarcze i zapobiegać jego nietrafnym decyzjom (Williamson, 1990). Neoliberalizm promuje zatem liberalizację gospodarki, prywatyzację i opowiada się za minimum państwa, doradzając krajom rozwijającym się ukształtowanie dobrze funkcjonujących instytucji rynkowych na wzór krajów rozwiniętych. Wyznawcy tej koncepcji wierzyli, że gdy rynek zacznie dobrze funkcjonować, dynamiczny rozwój i transformacja strukturalna nastąpią samoczynnie.

Zgodnie z wytycznymi konsensusu waszyngtońskiego wiele z krajów rozwijających się zastosowało w latach 80. i 90. „terapię szokową” w celu wdrożenia programów dostosowań strukturalnych. Interwencje rządu zastąpiła polityka doradztwa i wsparcia finansowego ze strony takich międzynarodowych instytucji, jak Bank Światowy czy Międzynarodowy Fundusz Walutowy. Zamysł dostosowania strukturalnego był słuszny, a analiza ekonomiczna tych programów wyglądała wiarygodnie i przekonująco, jednak wynik nie okazał się satysfakcjonujący. Tempo wzrostu w dwóch ostatnich dekadach XX wieku w wielu krajach rozwijających się było jeszcze niższe niż w latach 60 . i 70., a kryzysy jeszcze częstsze. W niejednym spośród nich mówiło się o straconych dekadach i nic dziwnego, skoro różnice dochodowe pomiędzy krajami rozwiniętymi i rozwijającymi się rosły coraz bardziej (Easterly, 2001). 


\section{Nowa generacja ekonomii rozwoju}

\subsection{Nowa Ekonomia Strukturalna}

Według raportu Banku Światowego z 2008 roku (Commission on Growth and Development, 2008) na temat wzrostu gospodarczego, po drugiej wojnie światowej trzynaście gospodarek osiągnęło wyjątkowy wynik, rosnąc średnio o co najmniej 7\% nieprzerwanie przez ok. 25 lat. Ta wygrana trzynastka posiadała pięć następujących cech wspólnych: 1) były to gospodarki otwarte; 2) utrzymywały stabilność makroekonomiczną; 3) miały wysokie oszczędności i wysokie stopy inwestycji; 4) utrzymywały dobrze funkcjonujący mechanizm rynkowy lub przynajmniej zmierzały w kierunku gospodarki rynkowej; 5) działały w nich wiarygodne, zaangażowane i proaktywne rządy.

Michael Spence, przewodniczący Komisji ds. Wzrostu Gospodarczego i Rozwoju (Commission on Growth and Development), podkreśla, że te pięć cech to wprawdzie składniki sukcesu, ale jeszcze nie przepis na sukces. Zdaniem autorów niniejszego artykułu, potrzebna jest nowa ekonomia rozwoju, która jest w stanie zapewnić spójną strategię obejmującą tych pięć cech skutecznie rozwijających się gospodarek. Ponadto, musimy zapewnić praktyczne wytyczne, którymi rządy krajów rozwijających mogłyby się kierować.

Trzecia generacja rozwoju, zaproponowana przez Lina $(2011 ; 2012)$, określana mianem Nowej Ekonomii Strukturalnej, jest zastosowaniem podejścia neoklasycznego do badania czynników wpływających na strukturę gospodarczą, zmiany strukturalne i ich wpływu na ewolucję rozwoju. Jak wyjaśnia Rodrik (2011), „kraje rozwijające się różnią się jakościowo od krajów rozwiniętych - nie są one jedynie promieniowo pomniejszonymi wersjami krajów bogatych. Aby zrozumieć wyzwania związane z opóźnieniami w rozwoju, trzeba zrozumieć, w jaki sposób ustalane są struktury zatrudnienia i produkcji, a zwłaszcza duże rozbieżności pomiędzy społecznym marginalnym produktem pracy w działaniach tradycyjnych w stosunku do działań nowoczesnych - i jak można pokonać przeszkody, które blokują przemiany strukturalne".

Głównym argumentem Nowej Ekonomii Strukturalnej jest, że struktury gospodarcze, w tym struktura technologii i przemysłu określająca wydajność pracy oraz twarda i miękka infrastruktura, która określa koszty transakcyjne są endogenne dla wyposażenia kapitałowego podanego w dowolnie określonym okresie i zmiennego w czasie.

Wyposażenie kapitałowe i struktura wyposażenia kapitałowego decyduja o całkowitym budżecie gospodarki i względnych cenach czynników w dowolnie określonym czasie. Te z kolei określają przewagę konkurencyjną i optymalną 
strukturę przemysłową. Oznacza to, że gdy struktura przemysłowa jest zgodna z przewagą komparatywną określaną przez strukturę wyposażenia kapitałowego, będzie miała najniższy współczynnik kosztów produkcji na rynkach krajowych i międzynarodowych. W związku z tym, kiedy struktura gospodarki w zakresie stanu zasobów awansuje z jednego poziomu rozwoju na inny, odpowiednio rozwijać się będzie optymalna struktura przemysłowa danej gospodarki.

Wzrost dochodów zależy od modernizacji struktury przemysłowej, której celem jest zwiększenie wydajności pracy. Ta z kolei zależy od modernizacji struktury wyposażenia przechodzącego od branż pracochłonnych do kapitałochłonnych. Wraz z modernizacją struktury przemysłowej wymagane są ulepszenia twardej i miękkiej infrastruktury w celu obniżenia kosztów i ryzyka transakcji.

Drugim najlepszym sposobem osiaggnięcia dynamicznego wzrostu i konwergencji - zaraz po przewadze komparatywnej (określonej przez strukturę zasobów) - jest rozwój różnych branż przemysłu. Gospodarka posiadająca rozwinięty przemysł i odpowiednią twardą i miękką infrastrukturę będzie najbardziej konkurencyjna, będzie też produkować największą nadwyżkę, generować największe możliwe zyski z kapitału, a tym samym oszczędności, jak również gwarantować najszybsze ulepszenie struktury wyposażenia kapitałowego i osiągnięcie najszybszej modernizacji przemysłu i wzrostu dochodów (Ju, Lin i Wang, 2015). W tym procesie kraj rozwijający się może czerpać korzyści ze swojego późnego startu i dzięki temu realizować innowacje technologiczne i przemysłowe szybciej niż kraje o wysokim dochodzie, co z kolei prowadzi do szybszego wzrostu i konwergencji z krajami o wysokim dochodzie.

Przedsiębiorców z kolei interesuje rentowność. Jak przełożyć ideę podążania za przewagą komparatywną kraju na wpływ na spontaniczne decyzje przedsiębiorców? Wymaga to dobrze funkcjonującego rynku - tak, aby względne ceny czynników odzwierciedlały ich względną podaż w wyposażeniu kapitałowym. Przy takich względnych cenach czynników przedsiębiorcy będą w interesie własnej rentowności i konkurencyjności na rynku angażować się w przemysł i stosować technologie zgodne z przewagą komparatywną określoną przez współczynnik zasobów.

Rozwój gospodarczy jest jednak procesem dynamicznym. Jest to proces ciągłych innowacji technologicznych i modernizacji przemysłu. Takie modernizacje i ulepszenia wymagają kogoś, kto wykona pierwszy ruch. W trakcie tego procesu pojawiają się dwa problemy związane z niedoskonałością rynku. Pierwszym z nich jest czynnik zewnętrzny, tzn. rząd musi stworzyć zachętę dla pierwszego gracza. Drugim jest koordynacja w celu poprawy instytucji i infrastruktury, które mają wpływ na koszty transakcji i na prawdopodobieństwo sukcesu pierwszych 
graczy. Tak więc, oprócz skutecznego mechanizmu rynkowego potrzebny jest rząd odgrywający aktywną rolę w ułatwianiu zmian strukturalnych.

Te dwa warunki, skuteczny rynek i państwo ułatwiające, to właśnie stylizowane fakty 4 i 5 z raportu na temat wzrostu gospodarczego. Jeśli kraj podąża za swoją przewagą komparatywną w rozwoju, otworzy swoją gospodarkę na rynek światowy (fakt 1) i osiągnie stabilność makroekonomiczną ze względu na swoją konkurencyjność (fakt 2). Podążanie za przewagą komparatywną wygeneruje największe nadwyżki i najlepsze zachęty do oszczędności i inwestycji (fakt 3). Zatem podążanie za przewagą komparatywną jest receptą na sukces w zakresie rozwoju gospodarczego (Lin, 2012, rozdz. 2).

Z perspektywy Nowej Ekonomii Strukturalnej strukturalizm zawiódł, ponieważ zignorowano endogeniczność struktury ekonomicznej kraju i zalecono promocję niektórych gałęzi przemysłu - zbyt zaawansowanych względem poziomu rozwoju kraju i przeciwstawiających się przewadze komparatywnej tego kraju. Przedsiębiorstwa takie były nierentowne na otwartych rynkach konkurencyjnych i wymagały subwencji rządowych oraz ochrony inwestycji początkowych, a także ciągłości działalności. Doprowadziło to do niewłaściwej alokacji zasobów, pogoni za rentą korupcji i zawłaszczania politycznego. Odnoszące sukcesy gospodarki Azji Wschodniej postąpiły inaczej: przyjęły strategie zorientowane na eksport w celu rozwinięcia pracochłonnej produkcji i wykorzystały przewagę komparatywną, jaką stanowiły ich bogate zasoby siły roboczej w latach 50. i 60. Strategia ta nie zaliczała się do tych, które zalecał strukturalizm.

Z kolei konsensus waszyngtoński oparty na neoliberalizmie również zawiódł, ponieważ zignorowano fakt, że interwencję, czyli wypaczenie zasady wolnorynkowej w krajach rozwijających się realizowano by chronić nierentowne firmy w sektorach priorytetowych (nierentowne, bo poprzednia strategia nie wykorzystywała przewagi komparatywnej). Rządom tych krajów zalecano natychmiastowe zaprzestanie interwencji, co spowodowało upadek starych sektorów priorytetowych i deindustrializację. Konsensus waszyngtoński sprzeciwiał się także przyjęciu przez rząd wytycznych polityki sektorowej, polegających na zapewnieniu zewnętrznych zachęt w postaci rekompensat i przezwyciężeniu niepowodzeń w zakresie koordynacji poprzez ulepszenie niezbędnej twardej i miękkiej infrastruktury w celu ułatwienia wprowadzania firmy do sektora zgodnego z przewagą komparatywną kraju.

W wypadku gospodarek przechodzących transformację od systemu centralnie sterowanego do wolnorynkowego, które w okresie transformacji osiagnęły stabilność i dynamiczny wzrost - takich jak Chiny, Wietnam i Kambodża w latach 80. oraz Mauritius w latach 70., ich rządy przyjęły pragmatyczne podejście dwutorowe. $\mathrm{Z}$ jednej strony, w okresie transformacji zapewniały ciągłe wsparcie dla 
nierentownych przedsiębiorstw w starych sektorach priorytetowych, a interwencji zaprzestawały dopiero wtedy, gdy przedsiębiorstwa w tych sektorach zyskały rentowność lub gdy dane sektory zmalały do bardzo nieznacznych rozmiarów. $\mathrm{Z}$ drugiej zaś - o ile przed transformacją prywatne firmy napotykały ze strony rządu same przeszkody, o tyle teraz ułatwiano im wchodzenie do sektorów zgodnych z przewagą komparatywną kraju. Ułatwienia takie przybierały postać tworzenia specjalnych stref ekonomicznych/parków przemysłowych w celu pokonania ograniczeń infrastruktury ${ }^{4}$, świadczenia kompleksowych usług na rzecz poprawy środowiska biznesowego oraz angażowania się w aktywną promocję rozwijanych projektów, aby przyciągnąć inwestycje zagranicznych firm do tych krajów w ramach ich globalnych łańcuchów wartości. W ten sposób zaś można uzyskać dostęp do rynku światowego (Lin, 2013).

Strategia ta przyczyniła się do osiagnięcia stabilności i dynamicznego rozwoju, a ponadto sprzyja ona mobilizacji kapitału krajowego i bezpośrednich inwestycji zagranicznych (BIZ). Jak na ironię, podejście dwutorowe postrzegane było jako najgorsze podejście do transformacji z punktu widzenia neoliberalizmu (Murphy, Shleifer i Vishny, 1992).

\subsection{Bariery rozwojowe a polityka przemysłowa}

Nowa Ekonomia Strukturalna stoi na stanowisku, że państwo odgrywa zasadniczą rolę w ułatwianiu szybkich innowacji technologicznych, modernizacji przemysłowej i dywersyfikacji ze względu na potrzebę zajęcia się problemami zewnętrznymi i rozwiązania problemów koordynacyjnych w celu poprawy infrastruktury i instytucji. Polityka przemysłowa jest dla państwa użytecznym instrumentem, który służy ułatwianiu transformacji strukturalnej. Wynika to z faktu, że koordynacja, niezbędna dla poprawy infrastruktury i instytucji, może się różnić w poszczególnych branżach przemysłu i miejscach, a zasoby i możliwości rządu są ograniczone, więc rząd musi je wykorzystywać strategicznie 5 .

Warunkiem sukcesu polityki przemysłowej jest jednak jej nakierowanie na sektory odpowiadające uśpionej przewadze komparatywnej danej gospodarki. Uśpiona przewaga komparatywna odnosi się do przemysłu, który ma konkurencyjne, niskie koszty produkcji na arenie międzynarodowej - czyli zgodne

4 Specjalne strefy ekonomiczne w wielu krajach nie działają $\mathrm{z}$ wielu powodów, takich jak nieprawidłowości $\mathrm{w}$ infrastrukturze i/lub brak skutecznych przepisów i wdrażania rozporządzeń, ulokowanie stref w źle dobranych miejscach, powody polityczne lub fakt, że rozwijane w nich docelowe branże przemysłu rozmijały się z tymi, w których kraj miał przewagę komparatywną.

5 Szersze omówienie kwestii roli państwa i polityki przemysłowej - zob. Aghion i Rouglet, 2014; Aghion i in., 2015. 
z określaną przez współczynnik zasobów przewagą komparatywną w kraju - ale w którym koszty transakcji są, ze względu na niewystarczającą twardą i miękką infrastrukturę, zbyt wysokie, aby zyskać konkurencyjność na rynkach krajowych i międzynarodowych.

Firmy działające w branży posiadającej uśpioną przewagę komparatywną będą opłacalne, a całe sektory konkurencyjne, gdy rząd pomoże przedsiębiorstwom pokonać problemy koordynacyjne oraz zewnętrzne $\mathrm{z}$ udoskonaleniem twardej i miękkiej infrastruktury w celu obniżenia kosztów i ryzyka w transakcji. W jaki sposób rząd ma wybrać sektory, które są zgodne z uśpioną przewagą komparatywną gospodarki? W zależności od odległości docelowej branży do globalnej granicy technologicznej, Nowa Ekonomia Strukturalna dzieli gałęzie przemysłu w kraju rozwijającym się - szczególnie w kraju wysokiej i średniej zamożności, takim jak Chiny - na pięć kategorii i zaleca rządowi wsparcie zgodnie z ich potrzebami rozwojowymi (Lin, 2017):

1) branże, w których kraj nadal ma do pokonania dystans do globalnej granicy technologicznej - rząd powinien określić główne niedomagania w zakresie infrastruktury, finansowania, kapitału ludzkiego itd. i pomóc w ich usunięciu;

2) branże, w których kraj znajduje się już na globalnej granicy - rząd powinien wspierać firmy w zakresie prac badawczo-rozwojowych w celu utrzymania pozycji lidera technologicznego na całym świecie;

3) branże, które już utraciły przewagę komparatywną, takie jak pracochłonne gałęzie przemysłu w Chinach - rząd powinien pomóc firmom przejść na branding, projektowanie produktów i zarządzanie marketingowe, czyli dziedziny o wysokiej rentowności lub przenieść produkcję do krajów o niskich kosztach pracy;

4) sektory o krótkich cyklach innowacji, które opierają się bardziej na kapitale ludzkim niż na kapitale fizycznym, w krajach posiadających duży kapitał ludzki (jak Chiny) oraz duży rynek krajowy - rząd może tworzyć parki inkubacyjne, zachęcać do tworzenia kapitałów wysokiego ryzyka oraz chronić własność intelektualną, aby sprzyjać innowacjom;

5) branże strategicznie ważne dla obronności kraju, w których kraj nie posiada przewagi komparatywnej - rząd powinien dotować je bezpośrednio wydatkami fiskalnymi zamiast wspomagać metodami regulacji cen innych interwencji rynkowych. 


\section{Państwo ułatwiające, przywódcy polityczni i idee}

\subsection{Droga do rozwoju}

Problemami dla kraju rozwijającego się mogą być nie tylko przemysł o niskim poziomie produktywności i słaba infrastruktura, lecz także zacofane, zdegenerowane, roszczeniowo nastawione instytucje, których zachowanie kształtuje negatywne zachęty dla społeczeństwa. Nowa Ekonomia Instytucjonalna stoi na stanowisku, że kraj osiągnie dynamiczny wzrost i zamożność, jeżeli jego instytucje będą tworzyły zachęty do pracy, gromadzenia kapitału ludzkiego i fizycznego, zdobywania lepszych technologii i poprawy alokacji zasobów (North i Thomas, 1973; North, 1981; 1990). Jeśli kraj ma źle funkcjonujące instytucje, które nie zachęcają ludzi do starań o osiągnięcie wzrostu gospodarczego, to będzie on słaby i pogrążony w stagnacji. Przykładowo, Acemoglu i in. (2001) oraz Acemoglu i Robinson (2012) twierdzą, że Wielka Brytania i Stany Zjednoczone są bogate, ponieważ posiadają instytucje integracyjne, które ograniczały siłę elit i kształtowały społeczeństwo o równomiernym rozłożeniu praw politycznych. Z kolei Ameryka Łacińska i Afryka są ubogie ze względu na swoje instytucje przemysłu wydobywczego.

Oprócz twierdzenia, że instytucje mają znaczenie, Nowa Ekonomia Instytucjonalna twierdzi również, że są one endogenne i są określane przez inne czynniki społeczne, gospodarcze i polityczne w gospodarce (North, 1981; North i Thomas, 1973). Co więcej, instytucje, które istniały setki lat temu, zachowują istotny wpływ na instytucje obecne oraz na poziom rozwoju gospodarczego, ponieważ instytucje są również kształtowane przez kulturę i historię, a zatem zmiana instytucjonalna podlega zależności ścieżkowej (path dependency) (Acemoglu i in., 2001; North, 1981).

Zgodnie z powyższą logiką, zacofanie instytucji wyjaśnia dlaczego ubogie kraje nie zdołały się rozwinąć. Państwo jako takie oraz ludzie są bezsilni, instytucji nie można bowiem zmienić egzogennie. Jeżeli przyjmie się sposób rozumowania Nowej Ekonomii Instytucjonalnej, badanie zagadnień rozwoju stanie się zajęciem depresyjnym, ponieważ nie jest ono w stanie zaproponować żadnego rozwiązania problemów rozwojowych.

Szybki przegląd gospodarek Cudu Azji Wschodniej (Bank Światowy, 1993) oraz trzynastu odnoszących sukcesy gospodarek w raporcie Komisji ds. Wzrostu Gospodarczego i Rozwoju (2008) pokazuje następujące cechy wspólne: pomimo że wcześniej tkwiły one w ubóstwie i borykały się z problemem złych instytucji, wszystkie posiadały zaangażowane, wiarygodne i zdolne rządy, które przyjęły system praworządności i inne regulacje sprzyjające osiągnięciu nowoczesnego 
wzrostu gospodarczego, jak również strategie rozbudowy eksportu, wykorzystując przewagę komparatywną wynikającą z ich ówczesnych poziomów rozwoju 6 . Oznacza to, że zerwanie jarzma złych instytucji jest możliwe, jeżeli państwo spełnia odpowiednią funkcję.

Patrząc jednak wstecz na wzrost gospodarczy na świecie, nietrudno dostrzec, że większość krajów ubogich nie miała rządów naprawdę świadomych tego, jak rozwijać środowisko biznesowe i zapewniać mu adekwatne, wydajne usługi publiczne (Besley i Persson, 2009; Bardhan, 2016).

Na każdym etapie rozwoju państwo ma odgrywać proaktywną, ułatwiającą rolę. Ograniczenia w rozwoju gospodarczym, które państwo musi usunąć będą różne dla różnych państw, a nawet dla jednego kraju na różnych etapach rozwoju. We wczesnym stadium rozwoju ograniczeniem dla kraju może być jego słaba infrastruktura, niskie umiejętności, złe otoczenie biznesu i zacofane instytucje, a dodatkowo różne zakłócenia i interwencje, jeśli kraj jest w trakcie transformacji ze strukturalnej strategii rozwoju do gospodarki rynkowej.

$\mathrm{Z}$ kolei dla kraju rozwiniętego wyzwaniem jest zapewne zyskanie czołowej pozycji w naukach podstawowych, niezbędnych do rozwijania nowych technologii/produktów lub kwalifikacji do pracy w nowych branżach. Jeżeli skuteczne instytucje i wydajne środowisko biznesowe nie mogą się rozwijać samoczynnie, a sektor prywatny nie jest w stanie zapewnić infrastruktury, konieczne jest, aby państwo wspomagało te dziedziny w interesie rozwoju gospodarki.

\subsection{Rola przywódców politycznych}

Przywódcy polityczni kierują rządem. Jeśli chcemy przeanalizować jakość rządowych wytycznych polityki i przepisów, musimy zrozumieć, co motywuje przywódców politycznych do określania polityki rządu (Lin, 1989). W każdym systemie osobisty interes przywódcy politycznego polega: 1) na utrzymaniu się przy władzy oraz 2) kiedy utrzymanie władzy nie jest zagrożone - na pozostawieniu po sobie dziedzictwa, włącznie $\mathrm{z}$ dobrym zapisaniem się $\mathrm{w}$ historii (Lin, 2009). Najlepszym sposobem pozostania u władzy i pozostawienia dobrego dziedzictwa jest zapewnienie dobrobytu społeczeństwu. Daje to gwarancję, że przywódca polityczny będzie wspierany przez ludzi, a historia dobrze go zapamięta. Jeżeli jednak idee przyświecające przywódcy politycznemu i jego polityka nie

6 Należy zauważyć, że wiele innych krajów również wprowadziło rządy prawa i inne regulacje, ale nie udało im się osiągnąć nowoczesnego wzrostu gospodarczego. Kluczowe znaczenie ma tu nie to czy wprowadzono rządy prawa, ale czy towarzyszy temu strategia rozwoju promująca rozwój przemysłowy zgodny z przewagami komparatywnymi danego kraju. Zostanie to omówione później. 
przynoszą dobrobytu narodowi, może on stracić poparcie ludu, a jego rola przywódcza może zostać zakwestionowana. Aby utrzymywać się przy władzy, przywódca polityczny może tworzyć grupy interesów wspierane poprzez patronat i umacniać swoją władzę kosztem dobrobytu społecznego, jednak taka postawa prowadzi do powstania błędnego koła. W związku z tym państwo wywłaszczające i chciwe elity można uznać za prawdopodobne konsekwencje niezdolności przywódcy politycznego do zapewnienia społeczeństwu dobrobytu.

Przywódca polityczny jest oczywiście zobowiązany do przestrzegania pewnych konwencji i ograniczony przez elity lub ludzi, którzy dali mu władzę, niemniej może on wykorzystać swoje kompetencje do załatwiania różnych spraw. Kluczem do sukcesu w kraju rozwijającym się o słabej infrastrukturze i instytucjach jest takie wykorzystanie władzy przez przywódców, aby ich działania przekładały się na szybkie sukcesy i na pobudzenie nowoczesnego wzrostu gospodarczego, także tworzenie enklaw w rodzaju specjalnych stref ekonomicznych. Ich dobra infrastruktura i środowisko biznesowe służą przebudzeniu uśpionej przewagi komparatywnej kraju. Takie szybkie sukcesy rozpoczynają samonapędzający się proces generujący więcej środków na rozwijanie infrastruktury i ulepszanie środowiska biznesowego w innych częściach kraju. Szybkie wygrane wzmacniają również autorytet przywódcy politycznego, co daje mu legitymację do przeprowadzania pożądanych reform instytucjonalnych. Wraz z dynamicznym wzrostem pojawia się nowa klasa przedsiębiorczości, a siła starych grup interesów stopniowo maleje. Dlatego to pragmatyczne podejście może być wykorzystane do przerwania impasu instytucjonalnego w kraju nękanym przez roszczeniowe grupy interesów, złe instytucje lub odziedziczone z przeszłości nadmierne zakłócenia rynku i interwencje (Lin i Monga, 2017).

Park Chung-hee w Korei Południowej, Chang Kaj-szek na Tajwanie, Lee Kuan Yew w Singapurze w latach 60. i Deng Xiaoping w Chinach od 1979 roku odegrali instrumentalną rolę w procesie pobudzenia rozwoju, który przekształcił ich gospodarki, pomimo że przed rozpoczęciem dynamicznej transformacji - podobnie jak w innych krajach rozwijających się - tkwily one w ubóstwie i zmagały się z problemami słabej infrastruktury i złych, zdegenerowanych instytucji. Literatura empiryczna pokazuje, że zmiana przywódcy kraju może mieć duże znaczenie dla wzrostu gospodarczego. Jones i Olken (2005) uważają, że zmiany przywództwa wykazują współzależność ze zmianami tempa rozwoju kraju.

Nawet przywódca polityczny, który zastaje państwo wywłaszczające i pazerne elity może mieć motywację, by użyć powierzonej sobie władzy do skierowania kraju na drogę integracji i szybkiego rozwoju - o ile tylko jest do tego przygotowany mentalnie i myśli takimi kategoriami. Przywódca taki ma największe szanse osiągnąć cel, jeżeli postępuje pragmatycznie i początkowo chroni zastane 
grupy interesów, aby zapewnić sobie stabilność polityczną i społeczną, jednocześnie uruchamiając nowe nisze - tak, jak było to w wypadku dwutorowej transformacji na Mauritiusie w latach 70. XX wieku oraz w Chinach i Wietnamie w latach 80. Celem strategicznym takich działań jest wygenerowanie samonapędzającego się cyklu wzrostu?

\subsection{Trafne pomysły i właściwe strategie rozwoju}

Dążąc do modernizacji, przywódcy polityczni w krajach rozwijających się przyjęli pewne strategie obejmujące zestaw wytycznych polityki, w tym różnych interwencji i rozporządzeń jako sposób na osiągnięcie swoich celów. Zestaw wytycznych polityki kształtował rozwój i jakość instytucji w ich krajach, co z kolei przekładało się na wyniki gospodarcze (Lin, 2009). Ze względu na złożony charakter modernizacji krajów rozwijających się i niejednakowy stopień rozumienia tych zjawisk u przywódców politycznych, za najbardziej praktyczne rozwiązanie w ramach starań o rozwój kraju uznawali oni podążanie za dominującymi ideami społecznymi. I właśnie dominujące idee społeczne kształtowały porządek instytucjonalny państw rozwijających się.

Problem polegal jednak na tym, że w dziedzinie dążenia do modernizacji dominująca myśl społeczna opierała się na błędnej percepcji głównych przyczyn i niedomagań krajów rozwijających się. Wiele strategii powstało pod wpływem poprzednich generacji ekonomii rozwoju, które wprowadzały przywódców politycznych w błąd i skaziły niejedną politykę ekonomiczną w tych krajach. W konsekwencji tego przywódcom nie tylko nie udało się dotrzymać złożonych obietnic, że ich kraje wejdą na drogę takich samych sukcesów, jakie stały się udziałem krajów rozwiniętych, lecz ich posunięcia prowadziły wręcz do stagnacji, częstych kryzysów, a nawet pociągały za sobą katastrofalne następstwa dla ich gospodarek (Lin, 2009). Tylko nieliczne kraje zdołały w tym okresie wydobyć się spod wpływu dominującej myśli społecznej - przykładem tygrysy Azji Wschodniej w latach 60. i Chiny w latach 80. Przywódcy tych rządów nie ulegali nadmiernym wpływom dominującej wówczas myśli społecznej, a ponadto w dobie transformacji przyjęli podejście pragmatyczne ${ }^{8}$.

Transakcje dokonywane bez tarć, kompletne informacje i jasno określone prawa własności - wszystko to są zjawiska pożądane, ale nieczęste w rzeczywistości - zwłaszcza gospodarek rozwijających się. Rząd może próbować narzucić instytucjom styl przeniesiony z kraju rozwiniętego, aby poprawić współczynnik

Obszerniejsze omówienie tego zagadnienia: zob. Lin, 2009, rozdz. 2; Lin i Monga, 2017.

8 Szersze omówienie kwestii poważnego wpływu myśli społecznej na wzrost gospodarczy kraju - zob. Buera i Shin, 2010. 
rynkowy i efektywność rynku produktów, zwiększyć przejrzystość informacji, zmniejszyć tarcia w transakcjach itd., ale takie zmiany instytucjonalne są trudne do osiągnięcia, ponieważ instytucje są oporne i podlegają zależności ścieżkowej. Bez endogenicznej siły dążącej do zmian instytucje funkcjonujące według narzuconego stylu mogą nie działać zgodnie z zamierzeniami (Lin, 1989). Konieczne jest zatem zrozumienie i rozwiązanie problemu rozwojowego od strony struktury wyposażenia kapitałowego gospodarki, w tym jej instytucji, zamiast wychodzenia od efektywnych założeń rynkowych neoklasycznej ekonomii.

Częstym problemem krajów o niskich dochodach są zacofane lub zdegenerowane instytucje. W tym kontekście nie jest najważniejsze czy państwo jest dość silne i skuteczne, by przezwyciężyć bariery instytucjonalne, lecz w jaki sposób przywódca polityczny korzysta z przyznanej mu władzy, by pobudzić rozwój. Różnica między Nową Ekonomią Strukturalną a innymi sposobami myślenia o rozwoju jest następująca: Nowa Ekonomia Strukturalna opowiada się za tym, aby kraj rozwijający się trafnie określił, co potrafi robić dobrze w oparciu o posiadane kompetencje i zasoby i aby stworzył warunki do rozbudowy tych dziedzin, a nie koncentrował się na tym, czego nie posiada lub nie potrafi zrobić dobrze, na tym, co wymagałoby atutów posiadanych przez kraje o wysokim dochodzie lub na zdobyciu takich kompetencji i zasobów, i próbach imitowania w tym zakresie krajów o wysokim dochodzie.

Najważniejsze jest, ażeby państwo w sposób pragmatyczny trzymało się właściwej strategii, pozwalającej optymalnie korzystać z zasobów w gospodarce oraz tworzyć zachęty dla poszczególnych prywatnych przedsiębiorstw do prowadzenia działalności gospodarczej, która zwiększy poziom dochodów kraju. Właściwe podejście realizujące właściwy pomysł jest tutaj ważniejsze od silnego państwa zalecanego przez niektórych ekonomistów. Jeśli strategia rozwoju jest zła, silne państwo może spowodować więcej szkód dla własnego społeczeństwa niż słabe państwo. Pod tym względem rację ma North (1981, s. 20), twierdząc, że silne państwo jest mieczem obosiecznym.

Innymi słowy, warunkiem pobudzenia i podtrzymania procesu rozwoju jest skuteczne państwo ułatwiające, które potrafi zapewnić podstawową infrastrukturę publiczną i pomóc gałęziom przemysłu z uśpioną przewagą komparatywną zyskać konkurencyjność poprzez ulepszanie infrastruktury i instytucji. Nawet przy ograniczonej zdolności i zasobach, zastając słabe instytucje i naciski ze strony grup interesów, przywódca polityczny - o ile ma dobre pomysły - i tak ma możliwość umiejętnie korzystać ze swojej władzy do tworzenia enklaw, takich jak specjalne strefy ekonomiczne i parki przemysłowe, z dobrą infrastrukturą i kompleksową obsługą, aby pobudzać dynamiczny rozwój zgodnie z zasadą optymalności Pareto. 
Dynamiczny rozwój, nawet wychodzący od małych enklaw, będzie dawać nadzieję ludziom, wzmocni siłę polityczną przywódcy i wygeneruje więcej środków na dalsze zmiany w gospodarce - przykładem Mauritius, który dzięki swej transformacji osiagał w latach 70. najlepsze wyniki w Afryce. Kraj ten odziedziczył zachodnią demokrację wielopartyjną, monokulturę rolniczą uprawy cukru, instytucje zaburzone przez strukturalizacyjną strategię zastępowania importu i nie miał silnego państwa, ale osiągnął znaczący wzrost zarówno poziomu życia, jak i potencjału państwa, rozpoczynając transformację od strefy przetwarzania i eksportu wyrobów włókienniczych i odzieżowych w 1970 roku (Subramanian i Roy, 2003). Wartość PKB na jednego mieszkańca w 2016 roku wyniosła tam 9628 USD. W ten sam sposób Chiny, Wietnam i kilka innych krajów Azji Wschodniej jest w stanie rozwijać się dynamicznie, pomimo że ich instytucje były wtedy bardzo słabe, a pomiary dokonywane przy użyciu wielu wskaźników makroekonomicznych, m.in. Doing Business i Indeksu Percepcji Korupcji, wykazują, że ich słabość trwa do dzisiaj.

I odwrotnie - jeżeli idea rozwoju jest zła, jak na przykład strukturalizm dla rozwoju i neoliberalizm dla transformacji, nawet kraj o silnych zdolnościach państwowych, jak obfitujący w zasoby Związek Radziecki, Argentyna i wiele innych krajów Ameryki Łacińskiej lub kraj o zdrowych instytucjach w punkcie wyjścia, jak Filipiny, Indie i inne postkolonialne kraje rozwijające się, będzie miał niską wydajność rozwoju. Dlatego podstawowym wyznacznikiem sukcesu lub porażki rozwoju w każdym kraju w warunkach wstępnych jest idea9 ${ }^{9}$.

\section{Konkluzje}

Od czasów drugiej wojny światowej główny nurt ekonomii został zdominowany przez ekonomię neoklasyczną, w której jednak brakuje roli państwa. Wiele innych form ekonomii rozwoju przewiduje różne role dla rządu, jednak są one niezadowalające.

Strukturalizm opowiada się za państwem rozwojowym i zazwyczaj rekomenduje ambitną industrializację na przekór przewadze komparatywnej. Celem jest tu zbudowanie zaawansowanych, nowoczesnych branż przemysłu i wykorzystanie ochrony rządu i subsydiów jako instrumentów polityki. Neoliberalizm propaguje minimum państwa i sprzeciwia się wykorzystaniu polityki przemysłowej. Jego receptą jest zbudowanie dobrze funkcjonujących instytucji rynko-

$\overline{9}$ Więcej szczegółowych argumentów w tym kontekście - zob. Lin, 2009; Lin i Monga, 2017. 
wych, a tezą - że na dobrze funkcjonującym rynku zmiany strukturalne nastąpią samoczynnie.

Ekonomie neoklasyczne poruszają problem wydajnych rynków. Nowa Ekonomia Instytucjonalna stanowi teorię na temat roli instytucji i pokazuje ich znaczenie. Stwierdza, że w kontekście rozwoju najważniejsze jest państwo i właściwe idee. Wyjaśnia i pokazuje, jak osiaggnąć optymalne wyniki rozwoju przy danej strukturze wyposażenia - wraz z proaktywną polityką rządu. Nowa Ekonomia Strukturalna stawia państwo i strategię rozwoju oraz transformacji w centrum nowej generacji ekonomii rozwojowej.

Niniejszy artykuł skupia się na roli państwa z punktu widzenia Nowej Ekonomii Strukturalnej. Opowiada się ona za państwem ułatwiającym, którego rola polega na ułatwianiu zmian strukturalnych za pomocą polityki przemysłowej, która pomoże przezwyciężyć niedoskonałości rynku i wesprze branże przemysłu posiadające uśpioną przewagę komparatywną, by mogły one osiągnąć konkurencyjność na rynku. Doktryna ta stoi na stanowisku, że drogą do osiągnięcia stabilności i dynamicznego rozwoju jest pragmatyczne, stopniowe, dwutorowe podejście do problemu transformacji.

Niniejszy artykuł zawiera wskazówki odnośnie do tego, jak rządy powinny kierować gospodarką i podkreśla, że rząd powinien promować gospodarkę w sposób zgodny z jej przewagą komparatywną. Rozwija również teorię państwa ułatwiającego i twierdzi, że w literaturze konwencjonalnej brakowało ważnej roli państwa: wywoływania zmiany instytucjonalnej i ułatwiania rozwoju gospodarczego.

Kraj słabiej rozwinięty cechuje się niską akumulacją kapitału, niskim poziomem kapitału ludzkiego, słabą infrastrukturą i zacofanymi lub zaburzonymi instytucjami, które stanowią barierę dla rozwoju. Autorzy niniejszego artykułu uważają, że przywódcy polityczni mogą odegrać kluczową rolę w kształtowaniu rozwoju narodów. Jednakże w tym kontekście nie jest najważniejsze czy państwo jest silne, czy słabe. Większe znaczenie ma skuteczne przywództwo polityczne i zachowanie pragmatycznego podejścia, czyli niezbędne warunki pobudzenia rozwoju w krajach rozwijających się.

Jeżeli pomysł jest właściwy, to nawet państwo słabe w początkowej fazie przemian może stworzyć enklawy, takie jak specjalne strefy ekonomiczne, aby pomóc krajowym przemysłom z uśpioną przewagą komparatywną zyskać status narodowej przewagi komparatywnej i uruchomić samonapędzający się cykl rozwoju. Jeśli jednak idea nie jest właściwa - na przykład w Chinach strategia nakierowana na przemysł ciężki sprzed transformacji w 1979 roku lub terapia szokowa podczas transformacji w Rosji w latach 90. - może to doprowadzić do powolnego wzrostu dochodów i niskiego poziomu rozwoju gospodarczego, jak miało to miejsce w obydwu wspomnianych wypadkach. 
Autorzy opowiadają się zatem za aktywną rolą państwa, choć w historii - i dawnej i całkiem najnowszej - przeważają porażki rządu w wielu częściach świata. Lewis (1955, s. 376) zauważa: „żaden kraj nie dokonał postępu gospodarczego bez pozytywnego bodźca ze strony inteligentnych rządów. (...) Z drugiej strony, istnieje wiele przykładów szkody wyrządzonej życiu gospodarczemu przez rządy”. Niemniej, Stiglitz (2011) ma rację, kiedy twierdzi, że interwencje nigdy nie będą idealne - wybór zachodzi pomiędzy niedoskonałymi rządami a niedoskonałymi rynkami, z których każdy ma pełnić funkcję kontrolną dla drugiej strony; należy więc postrzegać je jako komplementarne i szukać równowagi pomiędzy dwiema stronami tego wyboru. Równowagi, która jest nie tylko kwestią rozdzielenia konkretnych zadań pomiędzy te dwie możliwości, lecz także projektowania takich systemów, w ramach jakich możliwości te będą skutecznie ze sobą współgrały.

Aby zmniejszyć ryzyko niewłaściwych interwencji i zwiększyć prawdopodobieństwo sukcesu, Nowa Ekonomia Strukturalna opowiada się za organiczną relacją rynku i państwa, w której „rynek jest skuteczny tylko wtedy, gdy państwo odgrywa rolę ułatwiającą przezwyciężenie nieodłącznych nieprawidłowości w działaniu rynku, a ostatecznym celem ułatwień ze strony państwa jest zagwarantowanie skuteczności rynku”. Nowa Ekonomia Strukturalna stwierdza również, że państwa powinny korzystać ze swoich ograniczonych zasobów i możliwości wdrożeniowych pragmatycznie, według starannie określonych priorytetów, aby przezwyciężać ograniczenia i rozbudowywać te branże gospodarki, w których kraj ma uśpioną przewagę komparatywną (rozumianą jako to, co potrafi robić dobrze) w oparciu o posiadane zasoby (czyli to, co aktualnie ma). Jeżeli przywódca polityczny w kraju rozwijającym się realizuje takie zalecenia, każdy rozwijający się kraj ma zdolność pobudzenia ścieżki dynamicznego rozwoju gospodarczego, nawet jeśli od wieków tkwi w ubóstwie i boryka się ze słabą infrastrukturą, zepsutymi instytucjami i naciskami politycznymi grup interesów.

\section{Bibliografia}

Acemoglu, D., Johnson, S. i Robinson, J. (2001). The Colonial Origins of Comparative Development: an Empirical Investigation. American Economic Review, 91(5), 1369-1401. Acemoglu, D. i Robinson, J.A. (2012). Why Nations Fail: The Origins of Power, Prosperity, and Poverty. New York: Random House, Crown Business.

Agenor, P.R., Canuto, O. i Jelenic M. (2012). Avoiding Middle-income Growth Traps. Economic Premise, 98, World Bank.

Aghion, P., Cai, J., Dewatripont, M., Du, L., Harrison, A. i Legros, P. (2015). Industrial Policy and Competition. American Economic Journal: Macroeconomics, 7(4), 1-32. 
Aghion, P. i Roulet, A. (2014). Growth and the Smart State. Annual Review of Economics, 6(1), 913-926.

Bardhan, P. (2016). State and Development: The Need for a Reappraisal of the Current Literature. Journal of Economic Literature, 54(3), 862-892.

Buera, F.J. i Shin, Y. (2010). Financial Frictions and the Persistence of History: A Quantitative Exploration. Journal of Political Economy, 121(2), 221-272.

Commission on Growth Development. (2008). The Growth Report: Strategies for Sustained Growth and Inclusive Development. Commission on Growth and Development Final Report. Washington, DC: World Bank.

Easterly, W. (2001). The Lost Decades: Explaining Developing Countries' Stagnation in Spite of Policy Reform 1980-1998. Journal of Economic Growth, 6(2), 135-157.

Jones, B. i Olken, B. (2005). Do Leaders Matter? National Leadership and Growth Since World War II. Quarterly Journal of Economics, 120(3), 835-864.

Ju, J., Lin, J.Y. i Wang, Y. (2015). Endowment Structures, Industrial Dynamics, and Economic Growth. Journal of Monetary Economics, 76, 244-263.

Keynes, J.M. (1935/1964). The General Theory of Employment, Interest, and Money (first Harbinger edition). New York, Chicago, Brulingame: Harcourt, Brace and World.

Kuznets, S. (1966). Modern Economic Growth: Rate, Structure, and Spread. New Haven, CT: Yale University Press.

Lewis, A. (1966). Theory of Economic Growth. London: Allen and Unwin.

Lin, J.Y. (1989). An Economic Theory of Institution Change: Induced and Imposed Change. Cato Journal, 9(1), 1-33.

Lin, J.Y. (2009). Economic Development and Transition: Thought, Strategy and Viability. Cambridge, UK: Cambridge University Press.

Lin, J.Y. (2012). New Structural Economics: A Framework for Rethinking Development and Policy. Washington DC: the World Bank.

Lin, J.Y. (2013). Demystifying the Chinese Economy. The Australian Economic Review, 46(30), 259-68.

Lin, J.Y. (2017). Industrial Policies for Avoiding the Middle-income Trap: a New Structural Economics Perspective. Journal of Chinese Economic and Business Studies, 15(1), 5-18.

Lin, J.Y. i Monga, C. (2017). Beating the Odds: Jump-starting Developing Countries. Princeton, NJ: Princeton University Press.

Lin, J.Y. i Rosenblatt, D. (2012). Shifting Pattern of Economic Growth and Rethinking Development. Journal of Economic Policy Reform, 15(3), 171-194.

Lucas, R.E., Jr. (1990). Why Doesn't Capital Flow from Rich to Poor Countries? American Economic Review, 80(2), 92-96.

Mankiw, G., Romer, D. i Weil, D.N. (1992). A Contribution to the Empirics of Economic Growth. The Quarterly Journal of Economics, 107(2), 407-437.

Murphy, K.M., Shleifer, A. i Vishney, R.W. (1992). The Transition to a Market Economy: Pitfalls of Partial Reform. Quarterly Journal of Economics, 107(3), 889-906.

North, D.C. (1981). Structure and Change in Economic History. New York: W.W. Norton \& Co.

North, D.C. i Thomas, R.P. (1976). The Rise of the Western World: A New Economic History. Cambridge: Cambridge University Press.

North, D.C., Wallis, J.J. i Weingast, B.R. (2009). Violence and Social Orders: a Conceptual Framework for Interpreting Recorded Human History. Cambridge: Cambridge University Press. 
North, D.C. i Weingast, B.R. (2000). Introduction: Institutional analysis and economic history. The Journal of Economic History, 60(02), 414-417.

Rodrik, D. (2006). Goodbye Washington Consensus, hello Washington Confusion? A Review of the World Bank's Economic Growth in the 1990s: Learning from a Decade of Reform. Journal of Economic Literature, 44(4), 973-987.

Solow, R. (1956). A Contribution to the Theory of Economic Growth. Quarterly Journal of Economics, LXX, 65-94.

Williamson, J. (1990). What Washington Means by Policy Reform. In: J. Williamson (ed.), Latin American Adjustment: How Much Has Happened? Washington: Institute for International Economics.

World Bank. (1993). The East Asian Miracle: Economic Growth and Public Policy. Oxford, UK: Oxford University Press. 


\title{
Wykorzystanie Nowej Ekonomii Strukturalnej dla modernizacji i zwiększenia innowacyjności polskiej gospodarki
}

\begin{abstract}
W ostatecznym rozrachunku decydujące znaczenie dla sukcesu modernizacyjnego Polski będzie miało promodernizacyjne nastawienie przedsiębiorców, pracowników i konsumentów (a więc całego społeczeństwa). Aparatura Nowej Ekonomii Strukturalnej może być pomocna we wzmocnieniu roli państwa w sprostaniu wyzwaniom stojącym przed polską gospodarką, trzeba jednak mieć świadomość, że zastosowanie NES może zderzyć się z wieloma istotnymi wyzwaniami i ograniczeniami. Po pierwsze, duże firmy potrzebne do tworzenia innowacyjnej koalicji rozwojowej są albo własnością korporacji zagranicznych, albo pozostają własnością państwa. Po drugie, nieliczne polskie małe i średnie firmy rosną dostatecznie, aby podjąć wysitek konkurencji globalnej. Po trzecie, społeczeństwo, a w tym i przedsiębiorcy, odnoszą się nieufnie do instytucji państwa, a państwo z dużą nieufnością podchodzi do publiczno-prywatnych przedsięwzięć. I wreszcie, po czwarte, Polacy po latach niedoboru chcą konsumować, a nie oszczędzać, tym samym nie są podatni na obietnice poprawy przyszłego poziomu życia w zamian za zdyscyplinowane służenie interesom państwa i korporacji.
\end{abstract}

Słowa kluczowe: modernizacja, innowacje, rola państwa, przydatność NES.

\section{Wprowadzenie}

W ostatnich dekadach napisano tysiące artykułów i książek o innowacyjności przedsiębiorstw. Teorie Schumpetera z marginesu przesunęły się do głównego nurtu rozważań ekonomicznych. W tym kontekście rola państwa przedstawiana jest jako działalność wspomagająca inicjatywy przedsiębiorców i uczonych w ramach ekonomii wiedzy (knowledge economy).

Nowa Ekonomia Strukturalna (NES) inaczej rozkłada akcenty współzależności między państwem a podmiotami gospodarki - przedsiębiorstwami i gospodarstwami domowymi (czy w nomenklaturze funkcji produkcji: między kapitałem i pracą). W dalszej części staramy się pokazać w jakim zakresie jest to podejście lepiej dostosowane do wyzwań stojących przed gospodarkami usiłują- 
cymi dogonić kraje rozwinięte, w tym gospodarką polską jako małą gospodarką otwartą, a w jakim - podejście to może napotkać inherentne trudności.

Jak pokazywaliśmy w innym miejscu, zalecenia NES nie mogą być dosłownie przeniesione na warunki polskie. Wynika to w pierwszej kolejności z odmiennych długotrwałych uwarunkowań kulturowych - braku analogii dla tradycji relacji społecznych zbudowanych na gruncie konfucjanizmu (Jędrzejczak i Sterniczuk, 2017). Dodatkowym ograniczeniem są zobowiązania Polski w sieci powiązań prawnych i instytucjonalnych Unii Europejskiej - ograniczających dostępność pewnych mechanizmów polityki gospodarczej, np. przez zakaz subsydiowania firm oraz wymóg przestrzegania norm produktowych, ekologicznych oraz warunków pracy.

Nie oznacza to jednak nieprzydatności zasad i doświadczeń NES. Widzimy trzy wymiary jej wykorzystania, przystosowane do konkretnych realiów i wyzwań gospodarczej modernizacji Polski:

1) przeformułowania paradygmatu gospodarki,

2) formułowania i prowadzenia polityki gospodarczej,

3) uczestnictwa w gospodarce światowej.

W dalszej części zajmiemy się bardziej szczegółowo tymi trzema wymiarami możliwego wykorzystania NES w realizacji polskich wyzwań modernizacyjnych.

\section{Przeformułowanie paradygmatu gospodarki}

Pojęcie paradygmatu - założeń myślenia o gospodarce - wydaje się nie mieć wiele wspólnego ze skutecznym wykorzystaniem NES w rozwiązywaniu problemów innowacyjnej modernizacji polskiej gospodarki A.D. 2018. Tak jednak nie jest. Należy zauważyć, że paradygmat gospodarki rynkowej, jaki znamy z teorii ekonomii, jest produktem XIX wieku z domieszką legitymizacji dla działań rządu obserwowanych po wielkim kryzysie lat dwudziestych. To wtedy utrwalały się różne fragmenty rozumienia czym jest gospodarka rynkowa, jakie są jej „czyste” lub właściwe powiązania z państwem i jakie rozwiązania polityki gospodarczej mieszczą się w obrębie tego przyjętego paradygmatu gospodarki.

Środowisko ekonomistów i polityków gospodarczych z wielkim trudem i niechęcią dopuszcza zmianę paradygmatu, w ramach którego operuje. Jest to wynik nie tylko obrony karier, lecz także, a może przede wszystkim, znajomości i powszechności metodologii, a więc języka, w którym grupa się porozumiewa. 
W wielkim skrócie, podstawą (punktem wyjścia) obowiązującego paradygmatu myślenia o gospodarce rynkowej jest system wolnych w swych wyborach jednostek kierujących się zasadą maksymalizacji korzyści (homo oeconomicus). Wolny rynek może prowadzić do rozwiązań suboptymalnych, co jednak jest wynikiem niedoskonałości (market failure), a nie strukturalnych (nienaprawialnych) właściwości rynku. Spór toczy się więc o skalę niedoskonałości alokacji przez rynek. Istniejące spektrum poglądów zaczyna się od stanowiska, iż niewidzialna ręka rynku potrzebuje państwa tylko jako „nocnego stróża” pilnującego zasad fair play między uczestnikami rynku, a kończy się na przypisywaniu państwu ról zarówno pilnowania reguł gry, jak i twórcy oraz administratora infrastruktury gospodarczej i tzw. strategicznych przedsiębiorstw ${ }^{1}$.

W naszym rozumieniu, NES jest odejściem od rozumienia gospodarki jako „rynku, który wymaga większego lub mniejszego wsparcia ze strony państwa” na rzecz paradygmatu przedsiębiorców i państwa jako równorzędnych partnerów w podejmowaniu decyzji gospodarczych ${ }^{2}$. Jest to więc teza znacznie mocniejsza niż, przykładowo, pogląd wynikający z keynesizmu o uzupełniającej fiskalnej i monetarnej roli państwa w przywracaniu równowagi pełnego zatrudnienia.

Nie oznacza to jednak, że w NES partnerstwo między rynkiem a państwem jest zadaniem łatwym i nierodzącym napięć. Są to jednak problemy realizacji, a nie pryncypiów. NES promuje punkt widzenia, że wobec wyzwań, z którymi mierzą się tzw. kraje doganiające zamykanie się w ramach dyskusji „rynek czy państwo" nie prowadzi do dobrych rozwiązań, a raczej marnuje potencjał intelektualny na fałszywe spory, zasoby materialne zaś na tworzenie i wdrażanie nierealistycznych rozwiązań.

Trzeba podkreślić, że jest to perspektywa jakościowo inna od propozycji dominującej roli państwa (np. Mazucatto, 2013), która mimo wszystko jest stanowiskiem w sporze rynek czy państwo.

Paradygmat gospodarki NES, zakładając partnerstwo przedsiębiorców i państwa, wcześniej musiał założyć, że obie strony są do pewnego stopnia sobie

1 Ekstrema: (a) całkowitego wyeliminowania rynku, po latach daremnych prób krajów komunistycznych, znalazło swoje zasłużone miejsce na śmietniku historii, oraz (b) rynku bez państwa znalazło swoje schronienie na stronach Internetu.

2 NES nie poświęca istotnej uwagi gospodarstwom domowym jako podmiotom decyzji gospodarczych (jak to ma miejsce w ekonomii głównego nurtu wywodzącej się z klasycznego paradygmatu). Nie wynika to w naszym przekonaniu z lekceważenia decyzji gospodarstw domowych co do zachowań na rynku pracy oraz poziomu i struktury konsumpcji, ale ze względów pragmatycznych - możliwość kształtowania zachowań gospodarstw domowych wymaga dużo czasu (wręcz generacji), a rezultaty są niepewne. Ponadto NES to propozycja dla krajów doganiających, gdzie „głód pracy i podstawowych dóbr konsumpcyjnych” jest dominujący w decyzjach gospodarstw domowych. 
równe. Oznacza to, paradoksalnie, nie tyle wzmocnienie państwa, ile że państwo jest skłonne do samoograniczenia swoich instrumentów. Jest to koncepcja nawiązująca do historii rozwoju Japonii, później Korei Południowej, a obecnie realizowana jest w Chinach.

Formy partnerstwa można było odszukać w działaniach koalicji rozwojowej rządu i chaebols w Korei Południowej lub rządu i prywatnych korporacji w rozwoju Japonii w latach 1946-1970. W obu przypadkach to partnerstwo przebiegało w kontekście kultury będącej spadkobiercą konfucjanizmu, gdzie liberalna, zachodnia koncepcja partnerstwa jako współpracy równorzędnych aktorów jest wprost niewyobrażalna, szczególnie w tradycyjnych społeczeństwach, jakimi były te kraje. Nie można jednak wpaść w pułapkę stosowania zachodniego myślenia o dominacji państwa opartej na instrumentach administracyjnego przymusu. Zarówno w Japonii, jak i w Korei była to komunikacja pomiędzy władzą państwa a wolnymi, prywatnymi przedsiębiorcami. Przykładowo, utrzymywanie odrębnej opinii czy wręcz niechęć do działań zalecanych przez wszechwładne Ministerstwo Handlu Międzynarodowego i Przemysłu (MITI) w Japonii nie groziło ani utratą stanowiska, ani tym bardziej utratą własności prywatnego przedsiębiorstwa. Podobnie było w Korei Południowej. Zapobiegało to między innymi kumulacji błędów w polityce gospodarczej i wybranych kierunków rozwoju przedsiębiorstw.

Dobrą ilustracją tej zależności jest relacja między rządem i przedsiębiorcami w Japonii lat 50. XX wieku. Otóż MITI było na początku przeciwne rozwojowi przemysłu samochodowego oraz elektroniki. Samochody ciężarowe, maszyny budowlane, elementarny sprzęt gospodarstwa domowego były akceptowane, ale prywatne auta czy wyszukana elektronika - już nie. Biznes uparcie dążył jednak do celu i po latach ta rebeliancka koncepcja została przez MITI zaakceptowana, choć na początku strumień pomocy rządowej omijał te „nieprawomocne” biznesy. Jak wiadomo, efektem tego kierunku rozwoju było uzyskanie przez Japonię i Koreę dominującej pozycji na rynkach światowych.

Partnerstwo pomiędzy państwem a korporacją jest trudne do wyegzekwowania ze względu na różnicę wagi tych dwóch aktorów - państwo może w ostateczności odwołać się do swojego monopolu „użycia przemocy”. Niemniej jednak, gdy państwo ma za partnera prywatną korporację poszanowanie prywatnej własności wyznacza granice forsowanych koncepcji rozwojowych. W omawianym przypadku, gdyby MITI miało więcej kontroli nie mielibyśmy prawdopodobnie ani Sony, ani japońskich samochodów lub przynajmniej ich tworzenie uległo by poważnemu opóźnieniu. Partnerstwo oznacza zarazem i współpracę, i spór, a w ostateczności możliwość zerwania relacji. Tworzy to zdrową zasadę konieczności analizy perspektywy partnera i uzasadniania swojego stanowiska, zmu- 
sza do kompromisu. Te procesy umożliwiają wzajemną adaptację i tworzenie nowych rozwiązań będących bliżej opcji cenionych przez partnerów.

W tym kontekście niezwykle ciekawe dla gospodarki globalnej jest doświadczenie Chin. Ze względu na historyczną zaszłość skrajnie upaństwowionej gospodarki, mamy obecnie do czynienia z celowym „hodowaniem” przez państwo prywatnych korporacji mogących stać się partnerami programu modernizacyjnego.

Podsumowując, obok państwa jako twórcy polityki gospodarczej i kontrolera jej realizacji poprzez własność i podobnie drastyczne formy oraz państwa jako nocnego stróża jest więc miejsce dla państwa partnera prywatnego biznesu. Ta koncepcja wymaga jednak spełnienia dwóch elementarnych warunków, ze strony państwa - akceptacji faktu partnerstwa $\mathrm{z}$ autonomicznymi podmiotami zdolnymi kalkulować swoje interesy biznesowe, a tym samym poszanowania tych kalkulacji, natomiast ze strony biznesu - przyjęcia współodpowiedzialności za rozwój gospodarki, czyli systemu wykraczającego poza wąskie interesy pojedynczego biznesu. Tak właśnie stało się w Japonii i w Korei Południowej. W obu przypadkach mieliśmy do czynienia z ukształtowaniem się koalicji rozwojowych biznesu i państwa. W obu wypadkach także udało się przekonać resztę społeczeństwa do akceptacji tej koalicji i wysokiego poziomu oszczędności, co pozwalało na wysoką stopę inwestycji.

\section{Formułowanie i prowadzenie polityki gospodarczej}

Celem NES jest „wspomagana konwergencja” - działania na rzecz dogonienia wysoko rozwiniętych, zamożnych krajów Zachodu przez kraje aspirujące do dołączenia do tego ekskluzywnego klubu.

Zarówno teoria, jak i praktyka doganiania nie są zjawiskiem historycznie nowym, czego przykład daje np. Rosenstein-Rodan (1943).

Historycznym przykładem udanej modernizacji zarządzanej przez państwo są Prusy początku XIX wieku, które można uznać za wzór pioniera udanej centralnie zarządzanej całościowej reformy, jak mówi jeden z jej twórców, opartej na „trójwymiarowym prymacie: armii, wiedzy i konstytucji” (Gneisenau, za: Nipperdey, 1998).

Historia gospodarcza pokazuje jednak, że udana konwergencja przez modernizację jest niestety zjawiskiem stosunkowo niezbyt częstym. We współczesnym świecie konwergencja jest trudniejsza niż w historycznej przeszłości - oznacza bowiem nie tyle przyśpieszenie wzrostu przez wykorzystanie nieaktywnych zaso- 
bów pracy ${ }^{3}$, ile modernizację gospodarki przez alokacje czynnych zasobów do działań o wyższej wartości dodanej. W pierwszej kolejności jest to wyzwanie „modernizacji pasywnej” polegającej na adaptacji rozwiązań z Zachodu. W drugiej zaś - jest to wyzwanie „modernizacji aktywnej” opartej na tworzeniu i wdrażaniu oryginalnych własnych rozwiązań innowacyjnych.

Przyczyny sukcesów, ale i porażek programów modernizacyjnych można doszukać się zarówno po stronie struktury procesu modernizacji, jak i praktyki zarządzania tymże procesem ${ }^{4}$.

\subsection{Strukturalne uwarunkowania procesu modernizacji}

Po stronie struktury procesu modernizacji podstawowym problemem jest nieuniknione napięcie między „cyklem politycznym” a „cyklem modernizacyjnym”. O ile cykle polityczne w demokracjach operują w perspektywie kilku lat „od wyborów do wyborów", o tyle cykle modernizacyjne realizują się w perspektywie kilkunastoletniej wyznaczonej przez znaczące zwiększenie udziału gospodarki opartej na produktach innowacyjnych. Modernizacja systemowa, a więc polegająca na masowych innowacjach (a nie kilku nawet spektakularych udanych innowacjach wprowadzonych ad hoc) wymaga działań w długim okresie, wystarczającym dla przeprowadzenia i ,zakorzenienia” zmian instytucjonalnych i regulacyjnych decydujących o skutecznym transferowaniu wiedzy do gospodarki, jak również internalizacji odpowiednich zachowań uczestników. Stąd zrozumiała jest pokusa wśród krajów doganiających poświęcenia demokracji na rzecz modernizacji. Przypadek Chin również w tym względzie wprowadza historyczny precedens. Jeszcze kilka dekad temu przeważał pogląd, iż demokracja polityczna typu zachodniego jest warunkiem niezbędnym modernizacji, jednakże dotychczasowe sukcesy modernizacyjne Chin co najmniej osłabiają tę tezę. Oczywiście w przypadku Polski, chociażby ze względów zobowiązań międzynarodowych, taki dylemat nie ma miejsca, choć akceptowalny model demokracji, z uwagi na poszczególne rozwiązania realizowanej praktyki, jest dosyć pojemny.

W tym kontekście deklaracje polityków, ale również przedsiębiorców i menedżerów, iż innowacje - szczególnie oparte na rodzimej wiedzy - są warte bezwarunkowego poparcie są podejrzane. Innowacje oznaczają bowiem zaburzenie

3 Choć to też ma znaczenie szczególnie w ludnych Chinach i Indiach, a w perspektywie dekad również w Afryce.

4 Trzeba też jednak pamiętać, że konkretne historyczne przypadki sukcesu czy porażki zależą również od wielu niekontrolowanych czynników, jak np. osobowości przywódcy, przełomowych wydarzeń politycznych czy technologicznych, zagrożeń zewnętrznych. Tymi bez wątpienia ważnymi zjawiskami się nie zajmujemy. 
status quo i to na wielu poziomach. Innowacje powodują większe lub mniejsze zakłócenie porządku gospodarczego i społecznego dla wielu grup społecznych, przynajmniej w krótkim i średnim horyzoncie czasowym.

Z punktu widzenia państwa szczególnie zakłócający wpływ innowacji rozgrywa się na wrażliwym politycznie rynku pracy. Dlatego też zjawisko „zabijania innowacyjności" przez państwową politykę ochrony miejsc pracy w starych sektorach gospodarki jest reakcją uzasadnioną cyklem politycznym. Po pierwsze, związki zawodowe w starych sektorach są dobrze osadzone w strukturach politycznych. Nierzadko także zawody schyłkowych sektorów są postrzegane wysoko w społecznej gradacji zawodów (w Polsce takim przykładem jest zawód górnika). Sektory nowe, innowacyjne są pozbawione takich przewag $-\mathrm{z}$ definicji oferują mało miejsc pracy, a na dodatek często stanowią zagrożenie dla miejsc pracy w starych sektorach gospodarki.

Powodzenie (lub nie) społecznego procesu modernizacji przez innowacje jest uwikłane w cyrkularną zależność o charakterze „błędnego koła” (vicious circle): innowacje są motorem rozwoju, jednak aby innowacje stały się zjawiskiem napędzającym wzrost, potrzebne jest osiągnięcie dostatecznie zaawansowanego poziomu rozwoju gospodarczego. W konsekwencji, wyzwanie modernizacyjne na poziomie strukturalnym to przejście od gospodarki niskiego potencjału innowacyjnego (rys. 1) do gospodarka wysokiego potencjału innowacyjnego (rys. 2).

Rysunek 1. Cykl gospodarki niskiego potencjału innowacyjnego

Prosta niskoptatna
praca potaczona
$z$ wysokim bezrobociem
i niskim poziomem
aktywności zawodowej
\[ \]
4
Utrwalanie
ekstensywnego modelu
gospodarczego do
czasu wyczerpania
nadwyżek prostej
i taniej pracy

Niski popyt wewnętrzny $i$ duża niepewność pracy,

$\rightarrow$ maty popyt na produkty $i$ ustugi o dużej zawartości wiedzy

Brak motywacji dla innowacji: niskie wydatki na $B \& R$, mate kapitatowe inwestycje (maszyny i kadry)
Rysunek 2. Cykl gospodarki wysokiego potencjału innowacyjnego

Preferencje fiskalne dla

Wzrost ilości dobrze kształcenia pracowników i inwestycji innowacyjnych

Proinnowacyjne zamówienia publiczne

Przesuwanie w strone
intensywnego modelu
rozwoju z rosnacym
wykorzystaniem wiedzy
$i$ specjalizowanej
pracy

Przesuwanie $w$ strone Motywacja do innowacji: zwiększone wydatki $n a \quad B \& R$, kapitałowe inwestycje $w$ firmę $i$ ksztatcenie pracowników

Źródło: opracowanie własne.

Przejście od cyklu niskiego potencjału innowacyjnego do cyklu wysokiego potencjału innowacyjnego wymaga czasu oraz zarówno ekonomicznych, jak 
i społeczno-politycznych zmian. Aby kontynuacja tych wysiłków była możliwa w sposób nieprzerywany cyklem politycznym, konieczny jest concensus elit polityczno-gospodarczych. Przykład rozwoju Korei Południowej pokazuje jak ważne jest takie porozumienie.

Porozumienie elit politycznych i gospodarczych było na początku wymuszone przez dyktaturę generała Parka, jednak później zostało dość powszechnie przyjęte $\mathrm{i}$ jest kontynuowane do dzisiaj. W Korei okres przejściowy obejmował sześć 5-letnich planów rozwoju. Do połowy lat 70 . XX wieku motorem była tania praca, później do połowy lat 90 . były to inwestycje. Okres budowy potencjału został ukoronowany w 1996 roku członkostwem w OECD, a następnie intensywną koncentracją na innowacjach (U.S. Bureau of Labor Statistics, 2018).

Często, jako warunek przejścia od cyklu niskiego potencjału innowacyjnego do cyklu wysokiego potencjału innowacyjnego przyjmuje się poziom nakładów na badania i rozwój (B\&R). Nakłady te są oczywiście warunkiem koniecznym udanego przejścia jednakże z punktu widzenia polityki modernizacyjnej podstawowe znaczenie ma struktura nakładów (udział państwowych i prywatnych uczestników sektora badawczego) oraz „ssanie” innowacji przez przemysł. Strategia wymuszania innowacyjności przez znaczne zwiększanie wydatków państwa na $B \& R$ jakkolwiek przynosi pewne rezultaty, okupiona jest jednak marnotrawstwem.

Patrząc z perspektywy doświadczeń krajów, które wyszły z grupy aspirantów i uzyskały trwałą obecność w grupie liderów innowacyjnej gospodarki, wydaje się, że przejście od gospodarki niskiego potencjału do gospodarki wysokiego potencjału innowacyjnego wymaga uporządkowania kilku ważnych spraw:

- minimalizacji napięć pomiędzy cyklem politycznym a czasem koniecznym na uzyskanie efektów rozwojowych poprzez porozumienie elit politycznych i gospodarczych oraz uzgodnienie długookresowej strategii;

- poważnych inwestycji w B\&R, prawdopodobnie na poziomie $2.5 \%$ PKB i wspomaganego przez państwo rozwoju potencjału badawczego w korporacjach; chodzi tu o aplikacyjną orientację pozwalającą na przyśpieszone efekty badań naukowych;

- rozwoju systemu edukacyjnego ukierunkowanego na twórczość, nauki ścisłe, technologię i współpracę między ludźmi;

- mobilizacji społeczeństwa, opinii publicznej w kierunku rozwoju innowacyjności w życiu publicznym i gospodarce; wymaga to poważnego wysiłku propagandowego, instytucji i nakładów finansowych ${ }^{5}$.

Ten niezwykle istotny problem wykracza poza ramy tego rozdziału. Warto jednak zasygnalizować kluczowe znaczenie tzw. Sputnik moment - mobilizacji Stanów Zjednoczonych w obliczu wprowadzenia na orbitę radzieckiego Sputnika. 


\subsection{Praktyka zarządzania procesem innowacyjnym}

Wysoki odsetek nieudanych prób modernizacyjnych wynika w naszym przekonaniu z nadmiernego koncentrowania się na tym „co zrobić”, przy jednoczesnym niedostatecznym skupieniu się na pytaniu ,jak zrobić”.

Pytanie „co zrobić” nie tylko sprzyja „mierzeniu siły na zamiary”, lecz także prowadzi nieuchronnie do mnożenia zadań przez grupy interesów, biurokrację i polityków. Praktyka ta w swej istocie nie różni się od praktyki „podczepiania pod plan" znanej z gospodarki planowej. Działanie takie znakomicie ułatwia fakt, że liczne zadania dadzą się uzasadnić jako społecznie i ekonomicznie ważne (i takimi są w znacznej liczbie przypadków). W efekcie końcowym, program modernizacyjny cieszy się szerokim poparciem, lecz ma małą szansę realizacji ze względu na nieadekwatne zasoby materialne i ludzkie.

Pytanie, ,jak zrobić” wymaga krytycznej pogłębionej oceny dostępnych możliwości dla konkretnego kraju w określonym czasie. Trudność odpowiedzi polega na tym, że zakres możliwości jest węższy niż zakres wyznaczony przez diagnozę „co zrobić” i wymaga zawężenia liczby priorytetów, naruszającego tym samym oczekiwania poszczególnych grup interesów.

Pierwszym krokiem ku „co zrobić” jest realistyczna ocena miejsca kraju na globalnej mapie konkurencyjności w stosunku do innych krajów budujących swą przewagę na innowacyjności, nie zaś na niskich kosztach. Trzeba realistycznie ocenić swoje obecne miejsce na globalnej mapie konkurencyjności i szanse awansu. Mówiąc kolokwialnie, trzeba ocenić, w której lidze się obecnie gra i w której można by grać za kilka sezonów, awansując lub spadając w rankingu.

O wartości nawet najlepiej pomyślanego i społecznie akceptowanego programu modernizacyjnego decyduje jego realizacja, a to z kolei wymaga odpowiedniego continuum kadr - od szeroko rozumianego aparatu państwa, przez samorządy lokalne, do organizacji społeczeństwa obywatelskiego.

Sprawność aparatu w decydującym stopniu wyznacza jego stabilność i odpolitycznienie urzędników wybranych w oparciu o kryteria merytoryczności i uczciwości. Znaczenie aparatu urzędniczego państwa w zarządzaniu gospodarką jest szczególnie ważne, ale i złożone w przypadku realizacji polityki innowacyjnej. W przypadku kadr realizujących politykę innowacyjną ocena skuteczności kadry urzędniczej jest trudniejsza niż w innych obszarach działania państwa ze względu na „słabą algorytmiczność” takiej oceny oraz znaczny odstęp czasowy między działaniami a ich rezultatami. Istnieje podstawowa sprzeczność między cechami dobrej administracji - postępowania według standardowych reguł i unikania ryzyka - a innowacjami, z definicji zakłócającymi zastany porządek i obciążonych znacznym i słabo zdefiniowanym ryzykiem powodzenia. Stąd pokusa oceny 
na podstawie realizacji nakładów, np. wydania państwowych pieniędzy na $B \& R$, może prowadzić do marnotrawstwa środków i, co gorsze, tworzenia „potiomkinowskich wiosek" dających fałszywe poczucie sukcesu.

Stworzenie kadry urzędniczej spełniającej te warunki to dopiero pierwszy krok. W sprawnym systemie administracji zachowania urzędników są w znacznym stopniu kształtowane nie przez ich osobiste przymioty, a przez środowisko instytucjonalne - system zasad i motywacji, które powodują lub zakazują określonych działań. Zasady i przepisy, formalne i nieformalne, wspólnie definiują strukturę zachęt urzędników w określonej organizacji lub w sektorze publicznym jako całości. Obszar polityki innowacyjnej wymaga od urzędników wyjścia poza standardowy zakres oczekiwanych cech osobowościowych - niezbędny jest komponent zachowań biznesowych, np. zdolności podejmowania ryzyka oraz akceptacji zmniejszania w czasie roli administracji w danym obszarze.

Badania sprawności administracji pokazują, że niezależnie od państwa, na poziomie indywidualnych motywacji, aby dobrze wypełniać swoje obowiązki (w rozumieniu oczekiwań ze strony systemu), urzędnicy muszą widzieć związek między swoim wysiłkiem a przyszłą oceną ich pracy. Trwałość i konsekwencja tych związków kształtowane są przez środowisko instytucjonalne, w którym pracują (Manning, Mukherjee i Gokcekus, 2000). Jednakże związek między zachowaniami urzędników a instytucjonalnym środowiskiem nie jest deterministyczny. W tym samym otoczeniu niektórzy urzędnicy pracują nieudolnie (przy czym na ogół jest to wyuczona nieudolność, a nie wynik ich wrodzonej nieudolności), niektórzy wykorzystują swoją pozycję dla pozyskiwania ubocznych dochodów, w tym korupcyjnych, inni pracują sprawnie, mając jako priorytet interes publiczny. Możemy więc raczej mówić o przewadze pewnych zachowań w danym otoczeniu niż o wszechogarniającej regule.

Znajomość warunków sprawnego funkcjonowania administracji nie oznacza jednak automatycznie zdolności zreformowania samej administracji. Bank Światowy ocenia, że mniej niż połowa projektów wspierających reformy administracyjne zakończyła się sukcesem. Wśród przyczyn tak niskiej efektywności interwencji mających za cel wprowadzenie sprawniejszych i bardziej przystających do potrzeb współczesnego społeczeństwa systemów zarządzania publicznego Bank Światowy wskazuje na zbytnio zawężony, technokratyczny punkt widzenia na temat tego, co jest potrzebne w reformach sektora publicznego oraz zbytnie poleganie na „najlepszych praktykach” przenoszonych z krajów rozwiniętych, a często niemożliwych do wdrożenia w krajach rozwijających się. Warunkiem poprawy efektywności reform administracji publicznej powinna być „praca z lokalnymi partnerami dla lepszego zrozumienia i uwzględnienia szerokiej gamy motywacji i nacisków - zarówno wewnątrz, jak i na zewnątrz wła- 
dzy - które mają wpływ na funkcjonowanie administracji publicznej” (Manning, Mukherjee i Gokcekus, 2000, s. 1).

Problemem o kluczowym znaczeniu jest funkcjonalna relacja między światem polityki (rządzenia) i światem administracji (zarządzania). Polityczna atrakcyjność klientelizmu oraz zagrożenie korupcją w obszarach zamówień publicznych, państwowych subsydiów, podziału etatów w organizacjach państwowych i samorządowych powoduje, że szczególnego znaczenia nabiera stworzenie „chińskiego muru" między administracją a światem polityki. Dotyczy to administracji państwowej, ale może nawet w większym stopniu administracji samorządowej, gdzie granica między rządzeniem a zarządzaniem jest płynna (World Bank, 2008).

Tradycyjną metodą takiego oddzielenia administracji od polityki jest tworzenie służby cywilnej. Koncepcja ta wspiera się na dwóch filarach: merytorycznej kompetencji oraz stabilizacji zawodowej. Tak wybrani urzędnicy służby cywilnej są lojalni wobec interesu państwa ponad bieżącymi interesami partii rządzącej.

Historycznie wyłonienie służby cywilnej w krajach transformacji, w tym w Polsce, wymagało zmierzenia się z problemem „grzechu pierworodnego” - stabilizacji pierwszej generacji urzędników służby cywilnej - a więc ludzi pochodzących z systemu, który okazał się niesprawny administracyjnie. Na początku transformacji istniało ryzyko stabilizacji urzędników, którzy nie tylko zostali ukształtowani $\mathrm{w}$ systemie niesprawnym, lecz także szybko tracących merytoryczne kwalifikacje (pomijamy sprawę lojalności wobec nowego ładu politycznego) ${ }^{6}$. $\mathrm{Na}$ dodatek, akceleracja zmian zachodzących w gospodarce i społeczeństwie prowadzi do dodatkowego problemu funkcjonowania służby cywilnej - szybkiej deprecjacji merytorycznej wiedzy urzędników. Model „mandarynów administracji” był adekwatny do zarządzania w stabilnym otoczeniu. W czasach szybkich zmian niezrozumienie nowych technologii oraz społecznych zachowań i trendów może wręcz prowadzić do działań obstrukcyjnych, antyinnowacyjnych.

Niewątpliwą słabością polskiej administracji jest brak służby cywilnej, a więc klasy urzędniczej wybranej według kryteriów merytorycznych i niepodlegającej

$6 \quad$ Historycznie, problem ten rozwiązywano na różne sposoby. Przykładowo, w Wielkiej Brytanii istniała klasa właścicieli ziemskich (landed gentry), która dzięki zasadzie niepodzielności majątków ziemskich „wypychała” osoby dobrze przygotowane merytorycznie do służb cywilnej i kolonialnej. W kontynentalnej Europie służba cywilna była narzędziem sprawowania władzy „oświeconego" monarchy absolutnego. Systemy te zostały też odpowiednio przeniesione do dawnych kolonii. Specyficzny model przyjęły klasyczne Chiny, gdzie czynnik merytoryczny wyboru urzędników niezależnie od klasy był dominujący (słynne egzaminy znajomości tysięcy znaków pisma). Jednakże, w żadnym historycznym przypadku klasa służby cywilnej nie powstała w środowisku demokratycznego sprawowania władzy. $Z$ tej też przyczyny Stany Zjednoczone w znacznie mniejszym stopniu niż inne kraje Zachodu opierają administrację na służbie cywilnej, a w znacznie większym na politycznych nominatach. 
wymianie wraz ze zmianą partii rządzącej. Następujące po sobie partie rządzące dążyły do wymiany kadry służby cywilnej na lojalną wobec polityków, „falandyzując" ustawowe podstawy służby cywilnej, np. przez wprowadzenie zasady „pełniącego obowiązki” lub poprzez rezygnację z zasady konkursowego naboru. Potrzeba wynagrodzenia sojuszników partyjnych i zwyczajny nepotyzm nie były bez znaczenia. „Każdy rząd - wbrew zasadom służby cywilnej - przygotowuje i forsuje swój projekt ustawy, dla siebie, ale kiedy zaczyna on obowiązywać, rząd musi swe miejsce oddać następnemu. Można powiedzieć, że każdy z nich gotuje byt następnemu... Obywatele są ofiarami stałej atmosfery zagrożenia i niepewności" (Górzyńska, 2009, s. 198). Opinia ta jest niestety nadal aktualna.

W przypadku Polski trudność zbudowania administracji zdolnej zarządzać procesem innowacyjnym trzeba zderzyć z faktem bezprecedensowego wzrostu, w ostatnich dwóch dekadach, liczby absolwentów uczelni kierunków wymaganych w sprawnej administracji: ekonomii, prawa, zarządzania i administracji. W początkowym okresie transformacji opcja pracy w administracji przegrywała z otwierającymi się możliwościami w prywatnym biznesie, znacznie atrakcyjniejszym finansowo i społecznie. Poprawa ogólnego standardu pracy w administracji oraz zwiększenie konkurencji na rynku prywatnym spowodowały, że „praca w urzędzie" staje się rozważaną alternatywą dla młodych absolwentów uczelni. Potwierdza to tezę o upolitycznieniu zatrudnienia w administracji, ale również spółkach handlowych pod bezpośrednia kontrolą rządu i samorządów. Mając dostęp do wykształconych absolwentów, polska klasa polityczna nie musi budować z nich sprawnego, uniwersalnego politycznie aparatu urzędniczego.

Postępujące przesunięcie punktu ciężkości działań innowacyjnych z przestrzeni działań indywidualnych na styku nauka - przedsiębiorstwo do działań w przestrzeni społecznej wymaga zaistnienia nowego typu partnera dla administracji państwowej w prowadzeniu polityki proinnowacyjnej - możliwie szerokiego i zróżnicowanego wachlarza organizacji społeczeństwa obywatelskiego: od zrzeszeń producentów, przez niezależne ośrodki badawcze (think tanks), do organizacji charytatywnych. Doświadczenie krajów wysoko rozwiniętych potwierdza rosnącą rolę rozwojową, jaką odgrywają organizacje pozarządowe, w szczególności co do:

- pośrednictwa między administracją a obywatelami - z jednej strony, co do przekazu aspiracji, pytań i proponowanych alternatyw obywatelskich, z drugiej zaś - co do przekazu zamierzeń i działań rządowych w sposób zrozumiały dla obywateli; funkcja „przekładania” zamierzeń administratora polityki gospodarczej będzie miała coraz większe znaczenie, ponieważ coraz liczniejsze obszary polityki gospodarczej nie mogą być ocenione bezpośrednio przez obywateli i wymagają profesjonalnej, lecz niezależnej oceny; 
- społecznej kontroli działań administracyjnych (accountabiity), co do ich przejrzystości i wykorzystania środków;

- dostarczania usług, takich jak szkolenia, kwalifikowanie beneficjentów polityki itd.

Tkanka organizacji społecznych jest w Polsce ciągle niewystarczająco rozwinięta. Działalność taka nadal kojarzy się Polakom bardziej z bohaterami Żeromskiego niż systematyczną i pragmatyczną kontrybucją na rzecz swojego otoczenia niewymagającą jednak szczególnych życiowych poświęceń.

Bogato ustrukturyzowane społeczeństwo obywatelskie z gęstą siecią organizacji nie nastawionych na zysk, a obsługujących różnorodność społeczeństwa, to właściwość kultury protestanckiej (mając świadomość znacznego uproszczenia tej oceny). Niewątpliwą przyczyną słabego rozwoju systematycznej działalności organizacji społecznych w latach transformacji było pojawienie się możliwości polepszania dobrobytu swojej rodziny i bliskich przez zwiększony wysiłek zawodowy, bezpośrednio konkurujący o ten sam budżet czasowy z aktywnościami na rzecz „obcych”. Pojawiła się też możliwość okazjonalnej działalności charytatywnej (jak WOŚP), zjawisko pozytywne samo w sobie, ale dające ludziom usprawiedliwienie dla słabego uczestnictwa w organizacjach społecznych. Rolę odegrało też bez wątpienia złe doświadczenie organizacji pseudospołecznych czasu komunizmu. Jeszcze innym wymiarem tego zjawiska jest trwałość cech kulturowych.

Aktywność społeczna wspierająca działania modernizacyjne utrzymuje się od kilku lat na podobnym poziomie bez tendencji wzrostowych. Aktywna jest około $1 / 3$ społeczeństwa. W wolontariat w ramach formalnych organizacji zaangażowana jest $1 / 5$ jedna piąta, a w działania na rzecz osób spoza kręgu rodziny i znajomych lub na rzecz okolicy około $1 / 4$ społeczeństwa $^{7}$ (Adamiak, 2014).

\section{Uczestnictwo w gospodarce światowej}

W dającej się przewidzieć przyszłości będziemy wystawieni na coraz to brutalniejszą konkurencję w zglobalizowanej gospodarce zarówno o zasoby, jak i o rynki zbytu. Wpływa na to w pierwszej kolejności czynnik geopolityczny - rozszerzenie obszaru konkurencji o zasoby podażowe i rynki zbytu ze strony

7 Odsetek badanych deklarujących zaangażowanie w wolontariat na rzecz organizacji o charakterze charytatywnym jest prawdopodobnie zawyżony, część badanych mogła bowiem za wolontariat uznać materialne wspieranie tych organizacji. 
krajów dotychczas niebędących istotnymi podmiotami gospodarki światowej. Czynnik geopolityczny jest w sposób rewolucyjny wzmacniany przez nowe technologie obniżające koszty transakcyjne przemieszczania ludzi, rzeczy i informacji, a przez to pozwalające na tworzenie globalnych elastycznych łańcuchów produkcji - nowych reguł alokacji kapitału.

\subsection{Polska wobec wyzwań konkurencji globalnej}

W nowych warunkach zmianie ulegają też sposoby konkurencji, które dadzą Polsce szanse polepszenia swej pozycji w gospodarce globalnej. Dotychczas rozwój oparty na produkowaniu więcej tego samego, w najlepszym przypadku ze zmianą technologii prowadzącą do obniżki kosztów, był dominującą strategią rozwojową. W polskiej gospodarce nastąpiły, co prawda, poważne zmiany technologiczne i organizacyjne, nośnikiem których były nowe metody wytwarzania wdrażane do firm przez nowych, na ogół zagranicznych właścicieli przedsiębiorstw (prywatyzowanych i greenfield). Innowacyjność technologiczna i organizacyjna nie wynikała jednak z oryginalnych polskich wynalazków czy też presji polskich przedsiębiorców na ich wdrożenie. Miała miejsce w wyniku absorpcji technologii i rozwiązań organizacyjnych wynalezionych poza Polską, z reguły będących innowacyjnymi imitacjami w stosunku do zagranicznych firm matek.

Na ogół zagraniczni właściciele przedsiębiorstw zatrzymywali dobrze przygotowanych pracowników, rynek produktu, jak również markę produktu, a następnie modernizowali proces produkcji przez wprowadzenie nowych maszyn, doskonalili design produktu oraz marketing. Był to bierny proces niejako wtłaczania innowacji w gospodarkę. Przykładem może być rynek produktów mlecznych, gdzie pod starymi nazwami i smakami produktów kryje się często nowa technologia ich produkcji, pozyskania surowców i dystrybucji - ograniczająca koszty, w tym zatrudnienia.

Autonomiczny popyt na innowacje związany był z niejako organicznym odreagowaniem na nieudolność systemu gospodarki planowej. W czasie transformacji Polska doświadczyła prawdziwej eksplozji małych firm, zjawisko szeroko podziwiane na świecie jako dowód na naturalną potrzebę samorealizacji gospodarczej w warunkach gospodarki rynkowej. Transformacja stworzyła dostatecznie dużo przestrzeni dla idącej w miliony grupy ludzi przedsiębiorczych. Nowi przedsiębiorcy, zakładając małe firmy, siłą rzeczy kupowali nowe maszyny i technologie, bardziej wydajne w porównaniu z istniejącymi uprzednio, nawet jeśli z drugiej ręki po kilku latach używania na zachodzie. W polskich warunkach był to ciągle olbrzymi skok innowacyjny (podobnie jak pięcioletni Mercedes jest ciągle znacznie lepszy niż nowa Łada). 
Modernizacja oparta na „wypełnianiu luk” odziedziczonych z przeszłości ma oczywiście swoje ograniczenia - jej moc sprawcza wygasa wraz z usunięciem niesprawności starego systemu.

Dotychczasowa modernizacja dawała jedynie pośrednie wzmocnienie konkurencyjności gospodarki polskiej - zastąpienie lokalnymi produktami produktów importowanych ${ }^{8}$. Nie tworzyła jednak możliwości konkurencji na rynkach globalnych. Rozwój przez wchodzenie na wyższe poziomy w łańcuchu tworzenia wartości produktu oraz zmiany struktury gospodarki polegające na zwiększaniu udziału sektorów o większej produktywności i unikalności, to oczywiście najlepsza droga modernizacji, dająca największe szanse wzrostu produktywności i konkurencyjności w wymiarze nie tylko poszczególnych przedsiębiorstw, lecz także całej gospodarki i społeczeństwa. Jest to, mimo postępu ostatnich lat, wciąż w niezbyt znacznym zakresie przypadek Polski.

\subsection{NES wobec wyzwań konkurencji globalnej}

Wielką pokusą państwowych modernizatorów jest protekcjonizm gospodarczy. Dotyczy to zarówno ochrony starych przemysłów, jak i przemysłów raczkujących (infant industries). O ile taki model modernizacji mógł mieć sens jeszcze w XX wieku, o tyle nie ma go (a co ważniejsze instrumentów) w dobie wolnego handlu i pojawiania się innowacyjnych substytutów produktowych ${ }^{9}$.

Protagoniści NES są świadomi niepowodzeń aktywizmu modernizacyjnego państwa opartego na protekcjonizmie. W szczególności wyciągnięto wnioski z niepowodzenia popularnej w krajach Ameryki Łacińskiej w latach 60. i 70. $\mathrm{XX}$ wieku polityki substytucji importu, polegającej na wspieraniu krajowych producentów oferujących produkty zastępujące produkty z importu. Polityka ta, uzasadniana chęcią przyśpieszonej modernizacji, przyniosła skutki odwrotne do oczekiwanych. Pomimo krótkoterminowych korzyści, takich jak wzrost zatrudnienia i stworzenie ograniczonej ilości lepiej płatnych miejsc pracy, brak kon-

$8 \quad$ Przykładem może być wyparcie zagranicznych produktów spożywczych, masowo wchodzących na polski rynek w początkowych latach transformacji, przez produkty polskie, dzięki zwiększeniu ich atrakcyjności.

9 Rozgrywający się na naszych oczach dramat protekcjonizmu spod znaku America first czy francuskiej obrony przed „dumpingiem socjalnym” może mieć daleko idące konsekwencje dla programu innowacyjnej modernizacji w krajach, takich jak Polska. Symptomatyczna była reakcja E. Macrona na plany firm Whirepool przeniesienia produkcji z Francji do Polski. „Macron rozmawiał z regionalnym dziennikiem północnej Francji po środowym spotkaniu w Amiens ze strajkującymi pracownikami zakładów Whirlpool, które zostaną zamknięte ze względu na przeniesienie produkcji do Łodzi [...] W ciągu trzech miesięcy po wybraniu mnie (na prezydenta) podjęta zostanie decyzja w sprawie Polski” - powiedział Macron. Pozyskano z: https://www. bankier.pl/wiadomosc/Francja-Macron-opowiada-sie-za-sankcjami-wobec-Polski-3685431.html. 
kurencji prowadził do małej innowacyjności i niskiej produktywności, a w efekcie do wysokich cen przy słabej jakości lokalnych produktów w porównaniu z produktami z importu. Co więcej, uznaniowość protekcjonizmu prowadziła do wzrostu korupcji i pogłębienia się nierówności dochodowych (Lustig i in., 2013).

Dlatego też NES postuluje realizację programu modernizacyjnego w ramach gospodarki otwartej na wyzwania konkurencji w skali globalnej, wręcz wykorzystującej jej mechanizmy i efekty skali. Jest to propozycja oparta nie na grze zero-jedynkowej, lecz na działaniach z korzyściami dla wszystkich uczestniczących stron porozumienia. To z kolei wymaga koordynacji i kooperacji na poziomie państwowym. Przykładem takiej koordynacji ma być transgraniczny program tzw. Nowego Jedwabnego Szlaku.

Argumentem integrującym, leżącym u podstaw korzyści tak rozumianej koordynacji między państwami, ma być podobna relacja krajów doganiających w stosunkach z krajami wysoko rozwiniętymi - ich peryferyjność.

W relacji centrum - peryferie typ inwestycji, czy szerzej, międzynarodowy podział pracy ma charakter strukturalny. Zagraniczne inwestycje bezpośrednie w krajach doganiających z krajów Zachodu koncentrują się na ogół w sektorach tradycyjnych o małym stopniu ryzyka inwestycyjnego, a więc małym nasyceniu innowacjami. Inwestycje zagraniczne trafiają do sektorów o znacznym zużyciu energii i ze względów ekologicznych nietolerowanych w krajach rozwiniętych, takich jak cementownie czy stalownie oraz montowniach wykorzystujących tanią siłę roboczą (nie należy mylić montowni produktów wysokiej technologii z wprowadzaniem innowacji). Próby motywowania zagranicznych inwestorów do inwestowania w przedsięwzięcia innowacyjne, np. przez zaostrzenie regulacji ekologicznych, mogą prowadzić do konsekwencji odwrotnych od zamierzonych - ograniczenia napływu inwestycji do tradycyjnych sektorów i ucieczka do krajów gotowych zaakceptować warunki stawiane przez inwestorów.

Ograniczenie transferu innowacji z najwyższej półki do krajów peryferyjnych ma swoje racjonalne biznesowe podstawy. W pierwszej kolejności może być podyktowane słabszym przygotowaniem siły roboczej oraz niższymi kosztami zewnętrznymi (externalities) niż w krajach pochodzenia kapitału. Jakkolwiek siła robocza w Polsce może mieć (i często ma) wyższe formalne wykształcenie niż siła robocza w krajach rozwiniętych, jednak dla inwestora decydujące znaczenie ma wiedza praktyczna (tacit knowledge), a tę zdobywa się w praktyce, naśladując mistrzów zawodu oraz uczestnicząc w grupie pracowniczej. Są to zdolności trudne do przeniesienia między krajami czy społecznościami i nabywane latami. Wymagania wiedzy praktycznej są tym powszechniejsze i łatwiejsze do zdobycia, im niżej technologicznie w łańcuchu produkcji jest ulokowana działalność. 
Wyśrubowane normy ekologiczne i prawa pracy w krajach rozwiniętych są istotną przyczyną przenoszenia elementów działalności gospodarczej niespełniających tych norm do krajów gotowych do akceptacji mniej ostrych norm. Motywem lokalizacji jest więc możliwość eksternalizacji kosztów związanych z przestrzeganiem norm. Dotyczy to w znaczącym stopniu „brudnych” elementów łańcucha produkcji, z reguły o najmniejszym nasyceniu wysoką technologią i najmniej innowacyjnych.

Nie można też pomijać faktu, iż najnowsze, najbardziej innowacyjne produkty i technologie decydujące o przewadze konkurencyjnej są pod najściślejszą ochroną przedsiębiorstw, które je wytwarzają. Dlatego patrzą one z dużą podejrzliwością na propozycje ulepszeń proponowane przez podwykonawców z krajów peryferyjnych - ryzyko utraty monopolu w zakresie ulepszania produktu jest nieraz oceniane jako większe niż korzyści wynikające z możliwości obniżki kosztów.

$\mathrm{W}$ ograniczaniu przepływu innowacji centrum - peryferie istotną rolę odgrywają również czynniki pozabiznesowe. Zagraniczne korporacje w razie ograniczeń globalnego popytu są pod wielkim naciskiem politycznym - któremu często ulegają - do przeniesienia produkcji umiejscowionej wysoko w łańcuchu tworzenia wartości z kraju peryferyjnego do kraju pochodzenia inwestora. Kwestia tak zwanej narodowości kapitału, czy raczej ulegania zagranicznych właścicieli politycznym naciskom krajów ich pochodzenia, powróciła ze wzmożona siłą w następstwie kryzysu 2008 roku. Efektem likwidacji w kraju peryferyjnym produkcji o dużym nasyceniu nowoczesnymi rozwiązaniami innowacyjnymi jest niekorzystna zmiana struktury gospodarki na mniej innowacyjną oraz zmniejszenie puli dobrze płatnych miejsc pracy. W dłuższej perspektywie oznacza to likwidację miejsc zdobywania przez pracowników wiedzy praktycznej, co odbija się niekorzystnie na społecznej zdolności budowy potencjału innowacyjnego w skali całej gospodarki.

\section{Konkluzje}

Modernizacja gospodarki oznacza przechodzenie do modelu pozwalającego na uzyskiwanie znaczących przychodów z uczestnictwa w gospodarce światowej na wyższym poziomie łańcucha wartości w ramach istniejących sektorów gospodarki oraz zmiany struktury gospodarki polegającej na zwiększaniu udziału sektorów o wyższej produktywności i lepszej konkurencyjności globalnej.

Zadanie to nie jest łatwe, rezultaty w coraz większym stopniu zależą od umiejętności uruchomienia społecznej zdolności do innowacji jako systematycz- 
nej aktywności mającej na celu lepsze wykorzystanie dostępnych zasobów oraz lepsze zaspokajanie potrzeb, to zaś zależy od umiejętności współpracy - zawiązywania koalicji rozwojowych między państwem a przedsiębiorstwami. $\underline{\mathrm{W}}$ tym kontekście trzeba postawić pytanie, z kim ze sfery biznesu w Polsce nadchodzacych dekad państwo może tworzyć koalicję rozwojową?

Gospodarka polska jest zdominowana przez mikroprzedsiębiorstwa o zatrudnieniu do 9 osób (96\% całego zbioru). Polska gospodarka ma tylko około 3500 ( $0,2 \%$ całego zbioru przedsiębiorstw sektora niefinansowego) dużych przedsiębiorstw. Sektor dużych przedsiębiorstw jest zdominowany przez firmy państwowe i firmy kontrolowane przez kapitał zagraniczny. Wśród 10 największych firm (według wielkości sprzedaży) 54,9\% stanowią przychody spółek kontrolowanych przez państwo. Wśród krajów transformacji większy udział sektora kontrolowanego przez państwo jest tylko na Ukrainie (68,9\%) (Szarzec, 2016, s. 130). Średnia wielkość zatrudnienia w firmach kontrolowanych przez państwo wynosi 243 pracowników, przez kapitał zagraniczny 230, a przez kapitał krajowy 72 osoby. Sektor dużych firm kontrolowanych przez kapitał krajowy w zasadzie nie wzrasta, rośnie za to sektor firm kontrolowanych przez państwo (Błaszczyk, 2017).

Małe i średnie przedsiębiorstwa, mimo że stanowią trzon polskiej gospodarki w sensie proporcji zatrudnienia i kontrybucji do GDP, nie dysponują ani kapitałem, ani zasobami ludzkimi, aby w aktywny sposób uczestniczyć w rynku badań i rozwoju. Z kolei sektor przedsiębiorstw państwowych, mimo że obejmuje duże przedsiębiorstwa, ma tylko $8 \%$ przychodów z eksportu, co oznacza nieobecność na rynkach wysokiej konkurencji, które weryfikują potencjał innowacyjny.

Zagraniczne firmy w Polsce odgrywają i będą odgrywać w dającej się przewidzieć przyszłości znaczącą rolę we wprowadzaniu innowacji do polskiej gospodarki - zarówno kapitałowych, jak i bezkapitałowych. Dlatego też należy utrzymywać atrakcyjność Polski dla inwestycji zagranicznych, są one bowiem poważnym kanałem dopływu z zewnątrz nowych produktów, technologii i metod organizacji i zarządzania. Firmy zagraniczne mogą i powinny być traktowane jako ważne źródło innowacji dla polskich firm kooperantów. Wymaga to jednak umiejętnego wsparcia ze strony organów rządowych, co, jak pokazuje np. transfer technologii związanych z zakupem zachodniego uzbrojenia, nie jest zadaniem prostym.

Trzeba sobie jednak zdawać sprawę, że strategia taka oznacza dominację innowacji imitacyjnych, które są generowane i instalowane u polskich wykonawców w ramach zadań produkcyjnych zleconych z firm-matek działających globalnie. Innowacje niesuwerenne powodują dwa rodzaje ryzyka. Po pierwsze, innowacje takie mogą być wycofane z Polski w przypadku przeniesienia produk- 
cji do lokalizacji bardziej opłacalnych z punktu widzenia firmy-matki. Po drugie, innowacje niesuwerenne, na ogół ucieleśnione w importowanych maszynach, nie rozwijają miejscowego potencjału innowacyjnego, na przykład przez z wielu względów niemożliwą dla Polski odwróconą inżynierię, która leżała u podstaw początkowych sukcesu krajów dalekiego wschodu.

Coraz popularniejszym obszarem aktywizmu gospodarczego państwa jest wspieranie startupów, szczególnie w modnych obszarach, takich jak biochemia czy informatyka. Jest to działanie ważne, chociażby dla wyzwalania „społecznej energii innowacyjnej”, popularyzacji sukcesu opartego na talencie i wiedzy jako głównego koła napędowego nowoczesnych gospodarek. Trzeba jednak pamiętać, że dla przejścia od startupu do implementacji potrzebny jest cały biznesowy ekosystem, którego w Polsce niestety brak. Stąd też, zwiększając zaangażowanie państwa w rozwój startupów, nie należy oczekiwać ich istotnego wpływu na gospodarkę.

Kierunkiem modernizacyjnej koalicji rozwojowej, z którym obecny rząd wiąże największe nadzieje, ale również wywołującym największe kontrowersje, jest wykorzystanie dużych spółek (firm) kontrolowanych własnościowo przez Skarb Państwa. Uzasadnieniem formułowanym explicite jest fakt, że tylko te „niezagraniczne” firmy dysponują znaczącymi zasobami kapitałowymi niezbędnymi do realizacji kapitałochłonnych programów modernizacyjnych (jak np. centralny port lotniczy). Uzasadnieniem implicite jest łatwość „przekonania” zarządu tych spółek do inwestowania w wybrane programy. W przypadku spółek SP jest naturalnym odruchem odwołanie się do dominacji administracyjno-politycznej, jedynie formalistycznie ukrytej pod płaszczykiem interwencji właścicielskich. Ten zarzut odnosi się w jeszcze większym stopniu do przedsiębiorstw kontrolowanych przez samorządy, gdzie pokusa nepotyzmu i korupcji jest silniejsza ze względu na słabszą kontrolę społeczną ${ }^{10}$.

Sukces wykorzystania zasobów kapitałowych spółek SP w procesie modernizacji gospodarki wymaga kombinacji: (1) doboru kadr zarządzających na podstawie kryteriów czysto merytorycznych; (2) przestrzegania dobrych praktyk korporacyjnych (corporate governance) w szczególności wykluczenia interwencji „na telefon”; (3) profesjonalnego zewnętrznego systemu oceny (audytu) spółek.

10 W polskim prawodawstwie konstrukcja spółki SP pojawiła się w ustawie o prywatyzacji z 1990 roku (którą autorzy współtworzyli). Oryginalnym zamiarem było nadanie dużym przedsiębiorstwom państwowym „,w kolejce do prywatyzacji” formy rynkowej. Z perspektywy lat było to myślenie naiwne, niedoceniające politycznych interesów skupiających się wokół tych spółek. Tyle że alternatywy były także ułomne. Pokazała to prywatyzacja zarówno w Rosji, jak i Czechosłowacji. 
W efekcie tych ograniczeń, w przeciwieństwie do azjatyckich przykładów sukcesu, w Polsce polityka oparta na sugestiach NES nie ma oczywistego kandydata do tworzenia koalicji rozwojowej. Jest to najpoważniejsze ograniczenie tej koncepcji jako sugestii dla tworzenia strategii doganiania.

W tym kontekście lepsze zbalansowanie aktywności gospodarczej przez wzmocnienie współpracy z innymi krajami doganiającymi ma sens. W pierwszej kolejności, strategiczny pragmatyzm zaleca obecności na maksymalnie wielu rynkach, szczególnie w czasie daleko idących zmian w globalnym porządku gospodarczym. Gospodarka polska jest w znaczącym (według nas nadmiernym) stopniu zależna od gospodarki niemieckiej (1/4 eksportu). Jest to szczególnie istotne przy oczekiwanych szansach eksportowych na rynkach regionu Azji i Pacyfiku, które stają się najbardziej dynamicznym regionem wzrostu klasy średniej i związanego z tym popytu. W roku 2015 wydatki konsumpcyjne (PPP, w USD 2011 r.) USA stanowiły 4,7 biliona dolarów co stanowiło $13 \%$ światowych wydatków konsumpcyjnych, a dla Chin wynosiły 4,2 biliona dolarów, co stanowiło $12 \%$ światowych wydatków konsumpcyjnych, dla Niemiec odpowiednio 1,5 bilionów dolarów i 4\% światowych wydatków. Prognozowane wielkości dla roku 2030 wynoszą odpowiednio: dla USA 4,7 bilionów dolarów i 7\% światowych wydatków konsumpcyjnych, dla Chin 14,3 bilionów dolarów i 22\%, Niemiec 1 bilion i 2\% (Kharas, 2017).

Trzeba mieć jednak świadomość, że aspiracje modernizacyjne Polski mogą kolidować z interesami gospodarek i firm zarówno centrum, jak i peryferii; tak na poziomie strategicznym, jak i w konkretnych przypadkach. Model uczestnictwa w gospodarce światowej realizował się dotychczas przez relacje z inwestorami centrum. NES z jej zredefiniowaną rolą państwa i narodowego interesu, $\mathrm{z}$ jednej strony prowadzi do zredefiniowania współpracy z tradycyjnymi partnerami zachodnimi w kierunku większej selektywności oraz warunków inwestowania (np. wakacji podatkowych). Z drugiej zaś - wymaga nowych umiejętności prowadzenia polityki gospodarczej w warunkach innej kultury współpracy oraz asymetrii potencjału partnerów ${ }^{11}$.

Polskie firmy zaczynają wchodzić na rynek światowy, gdzie znajdują się pod wielką konkurencyjną presją premiującą technologie i produkty najnowsze. Toteż firm takich jest niewiele, za to dużo jest firm, które współpracują z największymi światowymi koncernami prowadzącymi działalność na skalę globalną. Tak dzieje się choćby w przemyśle samochodowym. Ci kooperanci też są pod presją: poszukiwania nowych metod zarządzania, produkcji, szkolenia pracowników, podnoszenia jakości. Pośrednio bowiem, podobnie jak koncerny dla

11 Symptomatyczna jest formuła „1+16” współpracy między Chinami a 16 państwami Europy Środkowo-Wschodniej - ludność „16” to mniej niż $10 \%$ ludności Chin. 
których pracują, konkurują na rynkach światowych. To sprzyja innowacyjności uzupełniającej. Dotyczy to przede wszystkim możliwości wzrostu firm średnich o polskim kapitale i oryginalnych polskich produktach i technologiach. Pojawia się pytanie, na ile państwo może świadomie „hodować” duże firmy oparte na polskim kapitale? Wydaje się, że korzystanie z oligarchicznych wzorów Azji napotkało by barierę społecznej nieufności mającej swe źródła w tworzeniu fortun w czasach burzliwej transformacji. Fortuny te nazbyt często powstawały bowiem w wyniku niejasnych związków miedzy aparatem państwa a biznesmenami (mimo że w Polsce praktyki te były znacznie rzadsze niż w byłym ZSRR).

W ostatecznym rozrachunku decydujące znaczenie dla sukcesu modernizacyjnego Polski będzie miało promodernizacyjne nastawienie przedsiębiorców, pracowników i konsumentów (a więc całego społeczeństwa). Aparatura Nowej Ekonomii Strukturalnej może być pomocna we wzmocnieniu roli państwa w sprostaniu wyzwaniom stojącymi przed gospodarką polską, trzeba jednak mieć świadomość, że zastosowanie NES może zderzyć się z wieloma istotnymi wyzwaniami i ograniczeniami. Po pierwsze, duże firmy potrzebne do tworzenia innowacyjnej koalicji rozwojowej są albo własnością korporacji zagranicznych albo pozostają własnością państwa. Po drugie, nieliczne polskie małe i średnie firmy rosną dostatecznie duże, aby podjąć wysiłek konkurencji globalnej. Po trzecie, społeczeństwo, a w tym i przedsiębiorcy, odnosi się nieufnie do instytucji państwa, a państwo z dużą nieufnością podchodzi do publiczno-prywatnych przedsięwzięć. I wreszcie, po czwarte, Polacy po latach niedoboru chcą konsumować, a nie oszczędzać, tym samym nie są podatni na obietnice poprawy przyszłego poziomu życia w zamian za zdyscyplinowane służenie interesom państwa i korporacji.

Dlatego też dalsza modernizacja gospodarki polskiej będzie wypadkową ograniczeń społecznych, politycznych i międzynarodowych oraz motywacji rozwojowych społeczeństwa. W systemie międzynarodowego krążenia towarów, usług, pieniędzy i ludzi czeka nas seria przystosowań, których charakter trudno dziś przewidzieć. Główne wyzwanie wewnętrzne stanowią sekularne zmiany demograficzne: starzenie społeczeństwa oraz spadek aktywności zawodowej. Paradoksalnie, przejście do rynku pracownika może okazać się silnym motywatorem dla przedsiębiorców do pracooszczędnych innowacji technologicznych i zarządzania.

Indywidualne motywacje konsumpcyjne społeczeństwa w Polsce są bardzo wysokie, natomiast motywacje na rzecz tworzenia form współkształtowania z państwem polityki rozwoju wydają się być niedostateczne. Rezultatem jest dominacja państwa w artykulacji celów i kierunków rozwoju, przy słabej partycypacji podmiotów gospodarczych i społecznych. Dla państwa pragnącego realizo- 
wać bardziej aktywną rolę gospodarcza zgodnie z zaleceniami Nowej Ekonomii Strukturalnej, może oznaczać to pułapkę błędnych, bo niepoddanych ocenie zewnętrznej, priorytetów polityki gospodarczej, jak również doboru niewłaściwych metod i ludzi do ich realizacji. „Przed porażką - wyniosłość, duch pyszny poprzedza upadek”. Ta mądrość króla Salomona powinna wisieć nad biurkiem każdego urzędnika realizującego politykę NES ${ }^{12}$.

\section{Bibliografia}

Adamiak, P. (2014). Zaangażowanie spoteczne Polek i Polaków. Wolontariat, filantropia, 1\% $i$ wizerunek organizacji pozarzadowych. Raport z badania 2013. Warszawa: Stowarzyszenie Klon/Jawor.

Błaszczyk B. (2017). Zmiany w systemie instytucjonalnym polskiej gospodarki. Wypieranie własności prywatnej rynku przez państwo w ramach „Dobrej Zmiany”. W: W. Gadomski (red.), Raport: Perspektywy dla Polski. Polska gospodarka $w$ latach 2015-2017 na tle lat wcześniejszych i prognozy na przyszłość. Warszawa: FOR. Pozyskano z: perspektywy.for. org.pl/wp-content/uploads/2017/11/Raport_Perspektywy_internet.pdf.

Górzyńska, T. (2009). Służba cywilna w Polsce: Problemy z tradycją, problemy z przyszłością. W: J. Supernat (red.), Między tradycja a przysztościa $w$ nauce prawa administracyjnego. Ksiega jubileuszowa dedykowana Profesorowi Janowi Bociowi (s. 189-199). Wrocław: Wydawnictwo Uniwersytetu Wrocławskiego.

Jędrzejczak, G. i Sterniczuk, H. (2017). Nowa Ekonomia Strukturalna a polskie wyzwania rozwojowe. W: J.Y. Lin, A.Z. Nowak (red.), Nowa Ekonomia Strukturalna wobec krajów mniej zaawansowanych. Warszawa: Wydawnictwo Naukowe Wydziału Zarządzania UW.

Kharas, H. (2017). The Unprecedented Expansion of the Global Middle Class, Global Economy \& Development, Working Paper, 100, February. Washington, DC: The Brookings Institution.

Lustig, N., Lopez-Calva, L.F. i Ortiz-Juarez, E. (2013). Deconstructing the Decline in Inequality in Latin America. Policy Research Working Paper, No. 6552. Washington, DC: World Bank. Pozyskano z: https://openknowledge.worldbank.org/handle/10986/15915.

Manning, N., Mukherjee, R. i Gokcekus, O. (2000). Public Officials and Their Institutional Environment: An Analytical Model for Assessing the Impact of Institutional Change on Public Sector Performance. Policy Research Working Paper, No. 2427. Washington, DC: World Bank. Pozyskano z: https://openknowledge.worldbank.org/handle/10986/19797.

Mazzucato, M. (2013). The Entrepreneurial State Debunking Public vs. Private Sector Myths. London-New York-Delhi: Anthem Press.

Mracek, K. (2012). Middle-Class Spenders Will Lead Global Growth. Washington, DC: Kiplinger Washington Editors Inc. Pozyskano z: https://www.kiplinger.com/article/business/T019-C021-S001-middle-class-spenders-will-lead-global-growth.html.

Nipperdey, Th. (1998). Deutsche Geschichte 1800-1866. Bürgerwelt und starker Staat. Munich: Verlag C.H. Beck.

12 Księga Przysłów, 16,18, przekład Biblia Tysiąclecia. 
PARP. (2017) Raport o stanie sektora małych i średnich przedsiębiorstw w Polsce 2017. Warszawa: PARP. Pozyskano z: parp.gov.pl/images/PARP_publications/pdf/raport $\% 20$ o\%20stanie \%20sektora \%20msp\%20w\%20polsce_2017.pdf.

Rosenstein-Rodan, P. (1943). Problems of Industrialization of Eastern and South-Eastern Europe. Economic Journal, 53(210/211), pp. 202-11.

Struktura sektora przedsiębiorstw w Polsce na tle krajów UE. (2018). Ernst and Young. Pozyskano z: https://www.ey.com/Publication/vwLUAssets/ey-raport-polskie-przedsiebiorstwa2017-02-mikrofirmy/\$FILE/ey-raport-polskie-przedsiebiorstwa-2017-02-mikrofirmy.pdf.

Szarzec, K. (2016). Przedsiębiorstwa państwowe w krajach Europy Środkowo-Wschodniej. Studia Ekonomiczne Uniwersytet Ekonomiczny w Katowicach, 260, 125-136.

U.S. Bureau of Labor Statistics. (2018). Real GDP per Capita in the Republic of Korea (South Korea) (DISCONTINUED) [KORRGDPC], August 31. FRED, Federal Reserve Bank of St. Louis. Pozyskano z: https://fred.stlouisfed.org/series/KORRGDPC.

World Bank. (2008). Public sector reform: what works and why? An IEG evaluation of World Bank support (English). Washington, DC: World Bank. Pozyskano z: http://documents. worldbank.org/curated/en/311251468150314338/Public-sector-reform-what-works-andwhy-An-IEG-evaluation-of-World-Bank-support. 


\title{
Proces doganiania rozwoju gospodarczego krajów OECD oraz rola bezpośrednich inwestycji zagranicznych w tym procesie
}

\begin{abstract}
Artykut składa się z dwóch części. W pierwszej opisujemy poziom rozwoju gospodarczego 51 krajów związanych z Organizacją Współpracy Cospodarczej i Rozwoju (OECD), wykorzystując w tym celu PKB per capita. Proponujemy podział tych krajów na trzy grupy: wysoko, średnio i nisko rozwinięte. Następnie, posługując się średniorocznym tempem wzrostu w okresie 2005-2016, wyróżniamy kraje: rozwijające się, w stagnacji i recesji. Łącząc obie te zmienne, proponujemy wyróżnić 7 podgrup krajów: od wysoko rozwiniętych uciekających, poprzez wysoko rozwinięte stabilne i doganiane do krajów średnio i nisko rozwiniętych doganiających.

W drugiej części artykułu analizujemy bezpośrednie inwestycje zagraniczne (FDI) w ujęciu globalnym, krajów OECD i Unii Europejskiej (EU), w szczególności badamy przepływy kapitałowe między wyszczególnionymi wcześniej trzema (wysoko, średnio i nisko rozwiniętymi) grupami krajów OECD. W ostatniej części, prezentujemy modele regresji potwierdzające dodatnie sprzężenie zwrotne między FDI i wzrostem gospodarczym. Świadczą one o procyklicznym działaniu bezpośrednich inwestycji zagranicznych.
\end{abstract}

Słowa kluczowe: kraje wysoko, średnio i nisko rozwinięte, OECD, kraje uciekające, doganiające i doganiane, bezpośrednie inwestycje zagraniczne.

\section{Wprowadzenie}

Nowa Ekonomia Strukturalna (New Structural Economics - NSE) jest teoretyczną bazą polityki gospodarczej państwa wspierającego wzrost gospodarczy, głównie dedykowaną dla gospodarek doganiających ${ }^{1}$. Doganianie jest atrybutem wszelkich wyścigów. Skłoniło to nas do zbadania, jak wygląda wyścig krajów w pogoni za najbardziej rozwiniętymi. Analizę ograniczamy do bazy danych 51 krajów związanych z Organizacją Współpracy Gospodarczej i Rozwoju (Organisation for Economic Co-operation and Developp-

1 Świadczy o tym chociażby tytuł artykułu J.Y. Lina „Nowa Ekonomia Strukturalna dla gospodarek doganiających" (zob. Lin, Nowak 2017). 
ment - OECD). Jest to rodzaj sprawozdania sportowego $\mathrm{z}$ wyścigu tych krajów w procesie rozwoju gospodarczego, jaki odbył się w latach 2005-2016.

Państwa powiązane z OECD mają różny status: 36 państw ma status członka; Polska przystąpiła do tej Organizacji w roku 1996; osiem państw aspiruje do członkostwa w OECD (np. Federacja Rosyjska), pozostałe uwzględnione w badaniu państwa mają podpisane umowy o wzmożonej współpracy (https:// data.oecd.org). Przynależność do OECD jest pewną nobilitacją państwa i ma niewątpliwy wpływ na ocenę ryzyka kraju i jego rating². Pełna lista uwzględnionych w badaniu krajów znajduje się na rysunku 1.

\section{Stopień i tempo rozwoju krajów OECD}

Za jedyny miernik poziomu rozwoju gospodarczego kraju przyjmujemy Produkt Krajowy Brutto na głowę mieszkańca (Gross Domestic Product per capita - GDP per capita). Jesteśmy świadomi jego ograniczeń informacyjnych, nie ma jednak innego tak bardzo syntetycznego wskaźnika. Rysunek 1 prezentuje poziom PKB per capita w krajach OECD w roku 2005, a więc na starcie opisywanego wyścigu. Przyznać należy, że rozpiętość poziomu PKB per capita jest bardzo wysoka. Najwyższy - 80 tys. USD jest w Luxemburgu, najniższy 707 USD - w Indiach. Proponujemy podział krajów OECD, uwzględniający PKB per capita, na trzy grupy:

- 19 krajów wysoko rozwiniętych PKB per capita, 30-80 tys. USD,

- 21 krajów średnio rozwiniętych PKB per capita, 5-30 tys. USD,

- 11 krajów nisko rozwiniętych PKB per capita, 700-5 tys. USD.

W pierwszej grupie na uwagę zasługuje 6 krajów o najwyższym poziomie PKB per capita: Luksemburg - 80 tys. USD (pozycja 1), Norwegia - 68 tys. USD (pozycja 2), Islandia - 58 tys. USD (pozycja 3), Szwajcaria - 55 tys. USD (pozycja 4), Irlandia - 50 tys. USD (pozycja 5), Dania - 49 tys. USD (pozycja 6). Kraje te, jak się wydaje, mają pewne wspólne cechy. Są to relatywnie małe kraje zachodnio-europejskie, posiadające wielowiekową tradycję gospodarki kapitalistycznej, które ominęły pożogi wojenne, w szczególności straty w II wojnie światowej. Stany Zjednoczone znajdują się na 7 miejscu (42 tys. USD), Niemcy zaś na miejscu 17 (35 tys. USD). Grupę krajów najbardziej rozwiniętych zamykają Włochy (31 tys. USD).

2 Przed przyjęciem Bazylei II, w obliczaniu współczynników wypłacalności banków dla należności od instytucji finansowych działających w krajach OECD przyjmowano wagę ryzyka 0,2, podczas gdy dla pozostałych wagę ryzyka 0,5 . 


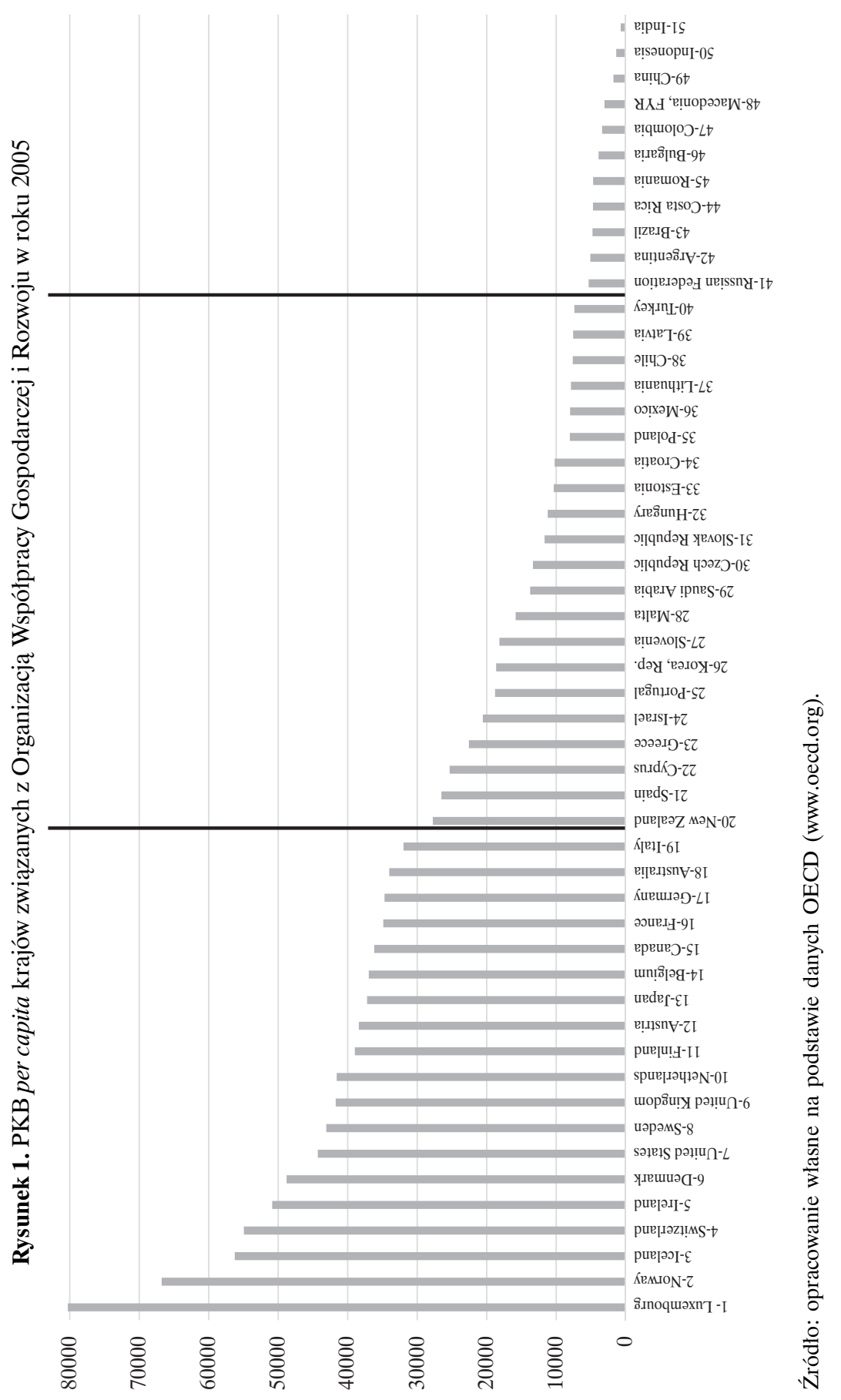


Drugą grupę krajów średnio rozwiniętych otwiera Nowa Zelandia (28 tys. USD), zamyka natomiast Turcja (7 tys. USD). Grupę tę tworzą południowo europejskie kraje zaliczane do grupy PIGS (Portugal, Italy, Greece, Spain) oraz kraje określane jako emerging markets: z Europy Środkowej i Wschodniej (w tym Polska -8 tys. USD; pozycja 35), z Azji (Turcja -7 tys. USD; pozycja 36) i z Ameryki Południowej (Meksyk - 8 tys. USD; pozycja 40).

Do trzeciej grupy krajów najmniej rozwiniętych należą duże kraje z Europy i Azji: Federacja Rosyjska - 500 USD (pozycja 41), Chiny - 200 USD (pozycja 49), Indonezja - 150 USD (pozycja 50), Indie - 100 USD (pozycja 51) oraz Ameryki Południowej: Argentyna - 400 USD (pozycja 42), Brazylia - 300 USD (pozycja 43).

Na rysunku 2 prezentujemy średnioroczne stopy wzrostu PKB w cenach stałych $(r)$ w 51 badanych krajach w latach 2005-2016. W skali globalnej w okresie tym, w latach 2005-2007, była wysoka i poprawiająca się koniunktura gospodarki, załamanie i kryzys w latach 2008-2010 oraz przezwyciężanie kryzysu i powrót do lepszej koniunktury w latach 2011-2016. Poszczególne kraje przechodziły to w sposób istotnie zróżnicowany. Najwyższe tempo wzrostu osiągały: Chiny $-10,4 \%$; Indie $-8,4 \%$; Indonezja $-6,1 \%$; Turcja - 5,0\%. Dwa kraje miały w tym okresie stopy ujemne: Grecja $-1,9 \%$; Włochy $-0,2 \%$. Polska ze średnioroczną stopą wzrostu $4,1 \%$ znalazła się na 13 miejscu po Chile $(4,2 \%)$ i przed Maltą (3,9\%). Uwzględniając średnioroczne tempo wzrostu, podzieliliśmy badane kraje na trzy grupy:

- kraje rozwijające się $(29) r=(+2+10 \%)$;

- kraje w stagnacji (15) $r=(+1+2 \%)$;

- kraje w recesji $(7) r=(-1+1 \%)$.

Zdecydowanie największa liczba krajów (29) odnotowała istotny wzrost gospodarczy. Co bardzo ważne z punktu widzenia NSE są to kraje z grupy najsłabiej i średnio rozwiniętych. Tylko 7 krajów odnotowało procesy stagnacji i recesji są to głównie: Japonia $(0,07 \%)$ oraz wybrane kraje europejskie: Finlandia $(0,08 \%)$, Cypr $(1,0 \%)$, Portugalia $(0,01 \%)$, Włochy $(-0,02 \%)$ i Grecja $(-1,9 \%)$. 

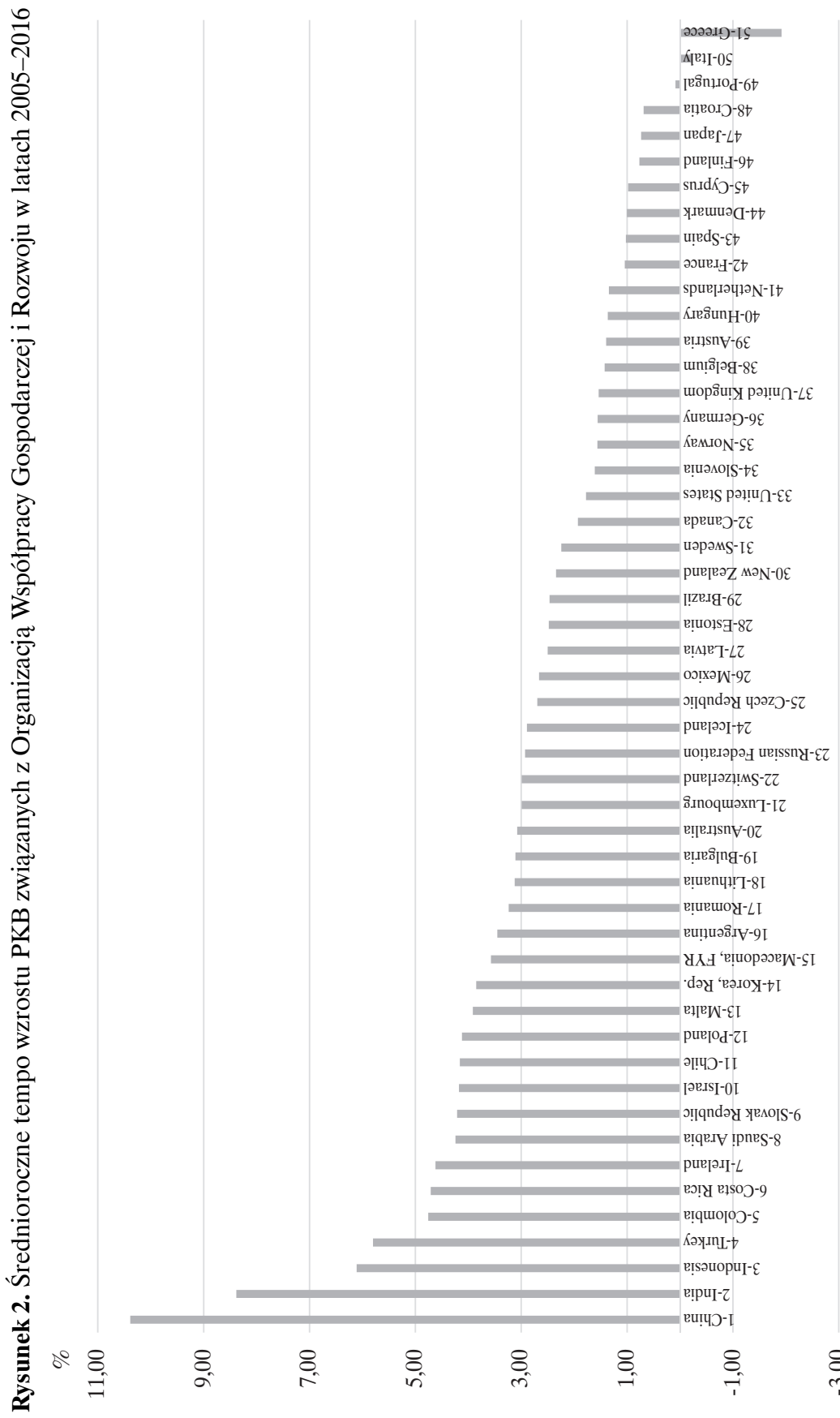
Uwzględniając dwa kryteria: poziom PKB per capita na początku okresu (2005 r.) oraz średnioroczne tempo wzrostu $(r)$ w okresie 2005-2016 możemy wydzielić w ramach 51 badanych krajów siedem ich grup.

Tabela 1. Klasyfikacja krajów OECD z uwzględnieniem PKB per capita w roku 2005, tempa wzrostu gospodarczego (r) w latach 2005-2016 oraz długoterminowego credit ratingu dotyczącego zobowiązań wyrażonych w walucie obcej przez S\&P

\begin{tabular}{|c|c|c|c|c|}
\hline Lp. & $\begin{array}{l}\text { Grupa } \\
\text { krajów }\end{array}$ & Kryteriumn & $\begin{array}{l}\text { Liczba } \\
\text { krajów }\end{array}$ & $\begin{array}{c}\text { Lista krajów wraz } \\
\text { z długoterminowym } \\
\text { ratingiem emitenta dotyczącym } \\
\text { zobowiązań wyrażonych w walucie obcej } \\
\text { publikowanym przez S\&P }\end{array}$ \\
\hline 1a & $\begin{array}{l}\text { Rozwinięte } \\
\text { uciekające }\end{array}$ & $\begin{array}{l}\mathrm{PKB}>30 \text { tys. USD } \\
\mathrm{r}>2 \%\end{array}$ & 5 & $\begin{array}{l}\text { Luksemburg AAA, Islandia AA-, } \\
\text { Irlandia A+, Szwecja AAA, } \\
\text { Australia AAA }\end{array}$ \\
\hline $1 b$ & $\begin{array}{l}\text { Rozwinięte } \\
\text { stabilne }\end{array}$ & $\begin{array}{l}\text { PKB }>30 \text { tys. USD } \\
\mathrm{r}=(+1+2 \%)\end{array}$ & 11 & $\begin{array}{l}\text { Norwegia AAA, Szwajcaria AAA, } \\
\text { Dania AAA, Stany Zjednoczone AA+, } \\
\text { Wielka Brytania AA, Holandia AAA, } \\
\text { Austria AA+, Belgia AA, Kanada AAA, } \\
\text { Francja AA, Niemcy AAA }\end{array}$ \\
\hline $1 c$ & $\begin{array}{l}\text { Rozwinięte } \\
\text { dościgane }\end{array}$ & $\begin{array}{l}\text { PKB }>30 \text { tys. USD } \\
r=(-1+1 \%)\end{array}$ & 3 & $\begin{array}{l}\text { Finlandia AA+, Japonia A+, } \\
\text { Włochy BBB- }\end{array}$ \\
\hline $2 \mathrm{a}$ & $\begin{array}{l}\text { Średniorozwinięte } \\
\text { dościgające }\end{array}$ & $\begin{array}{l}\text { PKB }=30 \text { tys. USD } \\
-7 \text { tys. USD } \\
r>2 \%\end{array}$ & 13 & $\begin{array}{l}\text { Nowa Zelandia AA, Izrael A+, } \\
\text { Korea Południowa AA, Malta A-, } \\
\text { Arabia Saudyjska A-, Republika } \\
\text { Czeska AA-, Republika Słowacka A+, } \\
\text { Polska BBB+, Meksyk BBB+, } \\
\text { Litwa BBB+, Chile AA, Lotwa A-, } \\
\text { Turcja BB }\end{array}$ \\
\hline $2 b$ & $\begin{array}{l}\text { Średniorozwinięte } \\
\text { stabilne }\end{array}$ & $\begin{array}{l}\text { PKB }=30 \text { tys. USD } \\
-7 \text { tys. USD } \\
\mathrm{r}=(+1+2 \%)\end{array}$ & 4 & $\begin{array}{l}\text { Hiszpania BBB+, Słowenia A, } \\
\text { Wegry BBB-, Estonia AA- }\end{array}$ \\
\hline $2 c$ & $\begin{array}{l}\text { Średniorozwinięte } \\
\text { dościgane }\end{array}$ & $\begin{array}{l}\text { PKB }=30 \text { tys. USD } \\
-7 \text { tys. USD } \\
\mathrm{r}=(-1+1 \%)\end{array}$ & 4 & $\begin{array}{l}\text { Cypr BB, Grecja B-, Portugalia BB+, } \\
\text { Chorwacja BB+ }\end{array}$ \\
\hline $3 a$ & $\begin{array}{l}\text { Słaborozwinięte } \\
\text { dościgające }\end{array}$ & $\begin{array}{l}\mathrm{PKB}<7 \text { tys. USD } \\
\mathrm{r}>2 \%\end{array}$ & 11 & $\begin{array}{l}\text { Federacja Rosyjska BB+, } \\
\text { Argentyna B-, Brazylia BB, Costa } \\
\text { Rica BB-, Rumunia BBB-, } \\
\text { Bułgaria BB+, Kolumbia BBB, } \\
\text { Macedonia BB-, Chiny AA-, } \\
\text { Indonezja BB+, Indie BBB }\end{array}$ \\
\hline
\end{tabular}

Źródło: obliczenia własne na podstawie danych OECD oraz Thomson Reuters Database.

Zdecydowanie największa liczba krajów (11) wysoko rozwiniętych znalazła się $\mathrm{w}$ grupie gospodarek stabilnych $\mathrm{z}$ umiarkowanym tempem wzrostu gospo- 
darczego (1-2\%). Do krajów tych należą: Stany Zjednoczone oraz główne kraje Unii Europejskiej (EU). Wszystkie kraje słabo rozwinięte oraz większość średnio rozwiniętych znalazło się w grupie krajów doganiających (24), co, jak się wydaje, stwarza dobre perspektywy rozwoju, popularyzacji i praktycznego wykorzystania idei oraz koncepcji NSE.

Zróżnicowane tempo wzrostu gospodarczego spowodowało zmiany w klasyfikacji krajów OECD pod względem PKB per capita. Klasyfikację tę na rok 2016 prezentujemy na rysunku 3. Na pierwszym miejscu utrzymał się Luksemburg, jednak PKB per capita wzrosło do 100 tys. USD. Przyczyną tego wzrostu jest jednak nie tylko relatywnie wysokie tempo wzrostu gospodarczego tego kraju, ale również wzrost kursu EUR do USD. Na drugim miejscu znalazła się Szwajcaria (80 tys. USD), pomimo umiarkowanego tempa wzrostu. Jest to przede wszystkim efekt umocnienia się FRS względem USD. Grupę 19 krajów najbardziej rozwiniętych opuściła Francja (38 tys. USD) i Włochy (29 tys. USD). $\mathrm{Na}$ ich miejsce do grupy tej weszły: Nowa Zelandia (40 tys. USD) oraz Izrael (39 tys. USD).

W grupie krajów średnio rozwiniętych w roku 2016 na pierwszym miejscu znalazła się Francja (37 tys. USD), na drugim Włochy (29 tys. USD). Grupę tę opuścił: Meksyk (4 tys. USD) i Turcja (5 tys. USD). Dołączyły zaś do niej Argentyna (12 tys. USD) i Costa Rica (11 tys. USD). Polska, pomimo relatywnie wysokiego tempa wzrostu gospodarczego $(4,1 \%)$, spadła w tej klasyfikacji z pozycji 33 na 38, co wynika przede wszystkim ze wzrostu kursu USD w PLN.

Bardzo wysokie tempo wzrostu gospodarczego Chin $(10,4 \%)$ przesunęło ten kraj z pozycji 49 na pozycję 46. Natomiast relatywnie wysokie tempo wzrostu w Indiach $(8,4 \%)$ i w Indonezji $(6,1 \%)$ nie przesunęło tych krajów z ostatniego i przedostatniego miejsca na liście najbogatszych krajów OECD.

Jak widać, krajowe ratingi agencji S\&P w roku 2016 są silnie skorelowane $\mathrm{z}$ zaproponowanym przez nas podziałem krajów OECD pod względem PKB per capita na trzy grupy. W pierwszej grupie krajów najbogatszych, poza Włochami, oceny mieszczą się w przedziale AAA - AA-. Niższa ocena Włoch (BBB-) wynika zapewne $\mathrm{z}$ wysokiego długu publicznego tego państwa (132\% PKB). Relatywnie niskie oceny Irlandii $(\mathrm{A}+)$ oraz Islandii są pokłosiem recesji tych dwóch gospodarek w okresie kryzysu 2008-2009.

Ratingi krajów w grupie średnio rozwiniętych są bardziej zróżnicowane i mieszczą się poza Grecją (B-) w przedziale AA (Nowa Zelandia) - BB (Cypr). Najniższa nota Grecji wynika z kryzysu zadłużeniowego tego państwa. Najniższe ratingi posiadają kraje $\mathrm{z}$ grupy słabo rozwiniętych i mieszczą się one w przedziale BB+ (Federacja Rosyjska) - BBB- (Indie). 


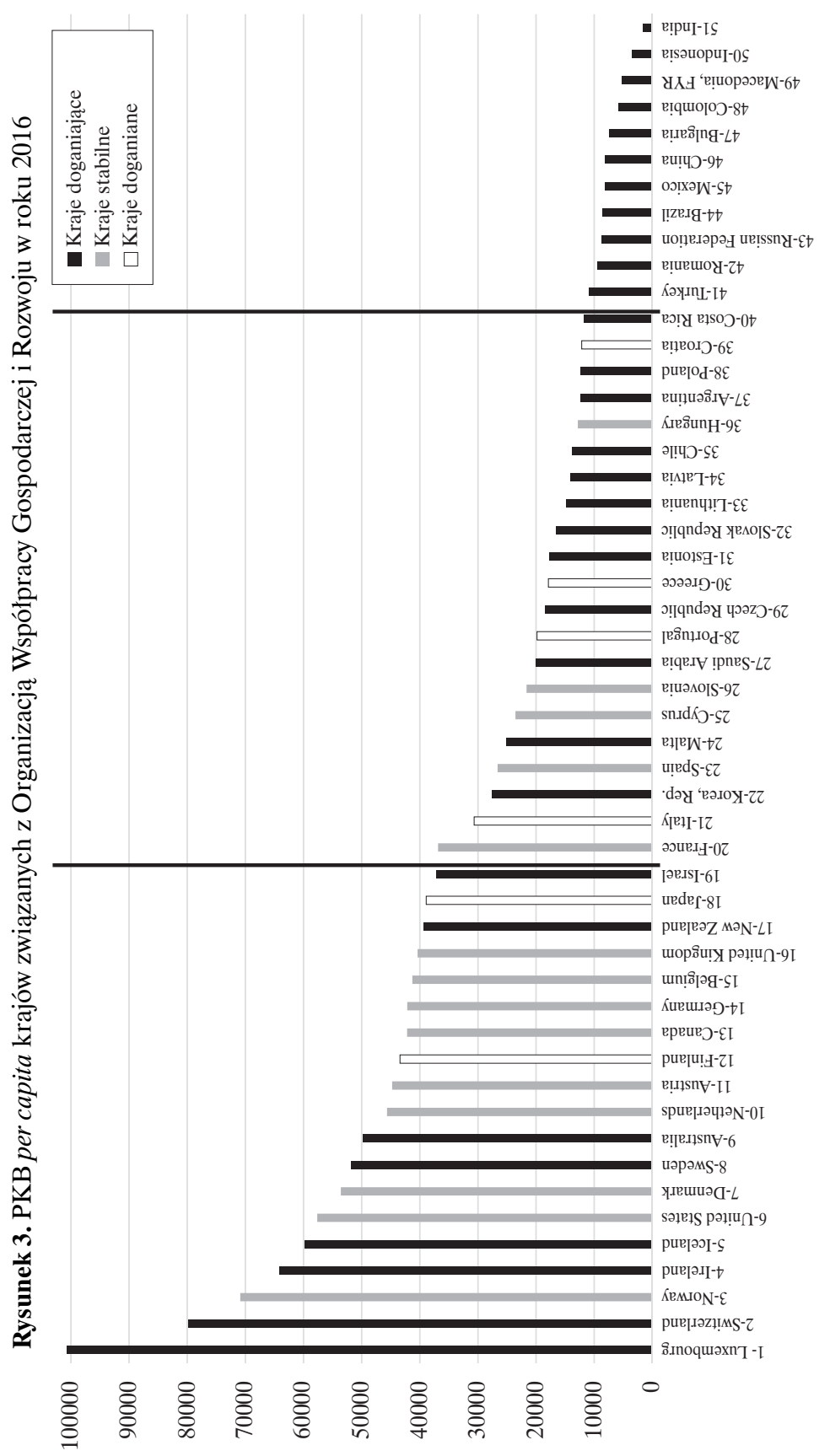




\section{Bezpośrednie inwestycje zagraniczne}

We współczesnej otwartej i zglobalizowanej gospodarce potencjał jej rozwoju niewątpliwie zależy od udziału kraju w wymianie międzynarodowej na wszystkich rynkach: towarowych, pracy i finansowych. W szczególności przeanalizujemy światowe przepływy kapitału w ramach tzw. bezpośrednich inwestycji zagranicznych (foreign direct investment - FDI). FDI są zestawiane i publikowane przez banki centralne.

Według definicji IMF i OECD są kategorią międzynarodowych inwestycji dokonywanych przez rezydenta jednego kraju (nazywanym „inwestorem bezpośrednim” lub „spółką-matką”) z zamiarem sprawowania długoterminowej kontroli w przedsiębiorstwie innego kraju (nazywanym „przedsiębiorstwem bezpośredniej inwestycji” lub „spółką-córką”). Przez długoterminową kontrolę rozumie się istnienie długoterminowych relacji między inwestorem bezpośrednim i spółką-córką, a istotny sposób oddziaływania, który daje inwestorowi bezpośredniemu efektywny głos w zarządzaniu przedsiębiorstwem, zależy od udziału inwestora bezpośredniego w kapitale spółki-córki. Minimalny próg zaangażowania kapitałowego inwestora bezpośredniego w spółce-córce ustalono na poziomie $10 \%$.

Komponentami FDI są: kapitał zakładowy (equity capital), reinwestowane zyski (reivested earnings) oraz inny kapitał (other capital). FDI w kapitał zakładowy związane są z:

- zakupem akcji, udziałów lub majątku spółki,

- aportem rzeczowym, np. w postaci maszyn i urządzeń,

- reinwestowanymi zyskami, częścią lub całością wypracowanych zysków (proporcjonalne do udziału inwestora bezpośredniego w kapitale spółki), które nie zostały wypłacone w formie dywidendy.

Inny kapitał to pożyczki wewnątrzkorporacyjne oraz transakcje związane $\mathrm{z}$ obsługą tego długu. Istotą FDI jest transfer nie tylko kapitału, lecz również pracy (np. udział przedstawicieli w zarządzie spółki-córki) i wiedzy (technologicznej, marketingowej i organizacyjnej).

Bezpośrednie inwestycje zagraniczne w krajowych bilansach płatniczych występują w następujących ujęciach:

- bezpośrednie inwestycje krajowe za granicą:

- napływ (inflow) - nabyte (objęte) przez rezydentów za granicą akcje (udziały, majątek) + reinwestowane zyski + przyrost długu spółek zagranicznych u rezydentów; 
- odpływ (outflow) - sprzedane przez rezydentów zagraniczne akcje (udziały - majątek) + wypłacone rezydentom dywidendy przez spółki zagraniczne + spłata długu przez spółki zagraniczne rezydentom;

- stan (stocs) - posiadane przez rezydentów na koniec roku (kwartału) akcje (udziały, majątek) + niespłacone długi spółek zagranicznych względem rezydentów.

- bezpośrednie inwestycje zagraniczne w kraju:

- napływ (inflow) - nabyte przez podmioty zagraniczne w kraju akcje (udziały, majątek) + reinwestowane przez podmioty zagraniczne w kraju zyski + przyrost długu spółek krajowych względem podmiotów zagranicznych;

- odpływ (outflow) - sprzedane przez podmioty zagraniczne akcje (udziały, majątek) + wypłacone przez rezydentów podmiotom zagranicznym dywidendy + spłata długu rezydentów dla spółek zagranicznych;

- stan (stocs) - posiadane przez podmioty zagraniczne w kraju akcje (udziały, majątek) + niespłacone przez rezydentów względem podmiotów zagranicznych długi.

Zgodnie z definicją OECD oraz Banku Światowego w statystykach międzynarodowych saldo napływu netto (net inflow) w ramach FDI to wartość bezpośrednich inwestycji dokonanych przez inwestorów zagranicznych w gospodarce sprawozdającej. Saldo wydatków netto (net outflow) natomiast to wartość bezpośrednich inwestycji zagranicznych dokonywanych przez rezydentów gospodarki sprawozdającej na zewnętrzne gospodarki. Inwestycje bezpośrednie, zwane również inwestycjami bezpośrednimi w gospodarce sprawozdającej, obejmują wszystkie zobowiązania i aktywa przenoszone między rezydentami instytucji dokonującymi bezpośrednich inwestycji a ich inwestorami bezpośrednimi. Obejmują również transfery aktywów i zobowiązań pomiędzy przedsiębiorstwami będącymi rezydentami i nierezydentami, jeżeli ostateczny dominujący członek kontroli nie jest rezydentem.

Zewnętrzne inwestycje bezpośrednie, zwane również inwestycjami bezpośrednimi za granicą, obejmują aktywa i pasywa przeniesione między bezpośrednich inwestorów i ich przedsiębiorstwami bezpośredniego inwestowania. Obejmują transfery aktywów i zobowiązań między przedsiębiorstwami będącymi rezydentami i nierezydentami, jeżeli ostateczny dominujący członek kontroli jest rezydentem. Zewnętrzne inwestycje bezpośrednie są również nazywane inwestycjami bezpośrednimi za granicą.

Dane o przepływach FDI są prezentowane również jako saldo (FDI netto): różnica między napływem kapitału do kraju sprawozdającego i odpływem 
kapitału z kraju sprawozdającego (należności minus zobowiązania między inwestorami bezpośrednimi i ich zagranicznymi podmiotami powiązanymi). Pomniejszenie wartości netto aktywów lub wzrost wartości zobowiązań netto są rejestrowane jako kredyty, natomiast wzrosty netto aktywów lub zmniejszenie netto zobowiązań są rejestrowane jako obciążenia. Stąd przepływy FDI ze znakiem ujemnym wskazują, że co najmniej jeden ze składników FDI jest ujemny i nie jest kompensowany dodatnimi wartościami pozostałych składników. Są to przypadki odwrotnej inwestycji lub dezinwestycji.

Rysunek 4. Napływ inwestycji bezpośrednich w mld USD

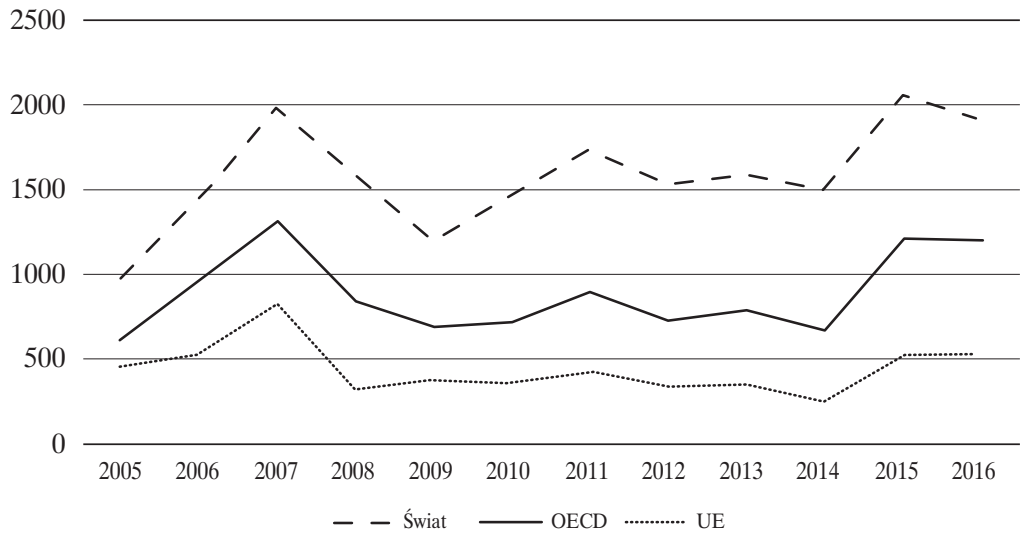

Źródło: opracowanie własne na podstawie danych OECD (www.oecd.org).

Rysunek 5. Odpływ inwestycji bezpośrednich w mld USD

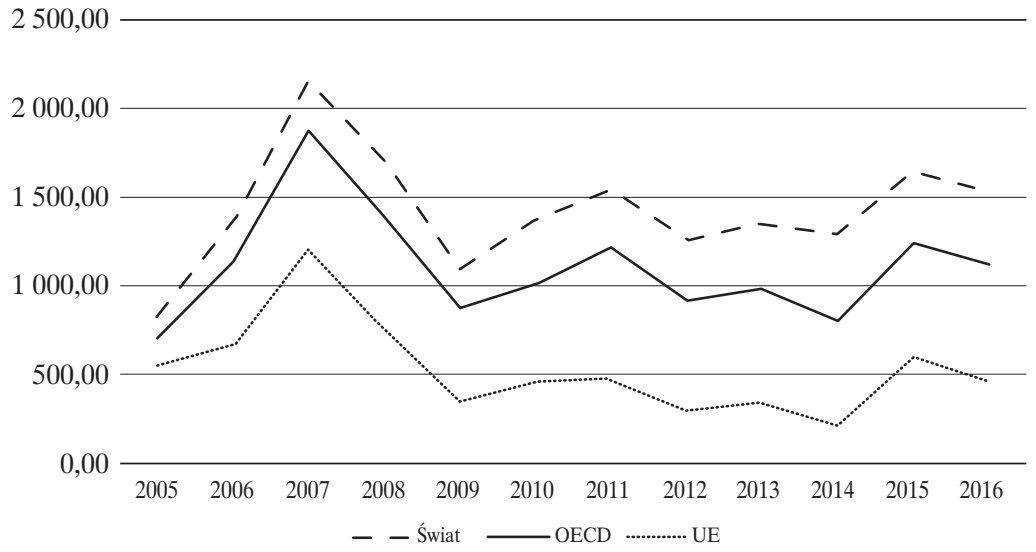

Źródło: opracowanie własne na podstawie danych OECD (www.oecd.org). 
Baza danych o FDI publikowana przez OECD obejmuje wartości rocznego strumienia napływu i odpływy inwestycji do i z poszczególnych krajów w USD, wartość rocznego salda napływu i odpływu kapitału w formie FDI oraz udział strumienia napływu FDI w PKB krajów goszczących i udział strumienia odpływu FDI w PKB krajów inwestujących.

Największy udział w napływie i odpływie kapitału w ramach FDI mają kraje OECD, przy czym ich udział w rocznych strumieniach odpływu wynosi około 90\% odpływów globalnych, podczas gdy w rocznych strumieniach napływu FDI wynosi tylko $62 \%$. Z tego wynika, że kraje OECD są w większym stopniu dostarczycielami inwestycji bezpośrednich do pozostałych krajów, natomiast w mniejszym stopniu są miejscem docelowym światowych inwestycji bezpośrednich.

L. Alfaro oraz J. Chauvin (2017) w swoich badaniach dowiedli, że rozwijające się gospodarki rosną w wyniku wzrostu inwestycji bezpośrednich, stwarzających jednocześnie szanse i zagrożenia dla krajów goszczących. W swojej analizie wykorzystali zmienne makroekonomiczne (stopę wzrostu PKB, zagregowaną produkcję, eksport) oraz mikroekonomiczne (pozytywne efekty zewnętrzne skutków ubocznych, powiązania i realokację kapitału). Korzyści gospodarcze są zróżnicowane względem poziomu rozwoju gospodarczego z tytułu napływu inwestycji bezpośrednich. Firmy zagraniczne częściej inwestują kapitał w gospodarkach słabo rozwiniętych niż w rozwiniętych, gdzie mogą gromadzić fundusze na szczeblu lokalnym. Oba typy gospodarek prawdopodobnie skorzystają na podwyżkach płac i eksporcie z powodu obecności zagranicznego kapitału, choć potencjalnie będą to różne kanały. W słabo rozwiniętych gospodarkach eksport może wzrosnąć, ponieważ firmy zagraniczne mają mniejsze ograniczenia finansowe i mogą sobie pozwolić na stały koszt eksportu, w gospodarkach rozwiniętych eksport może wynikać z tego, że firmy zagraniczne unikają większej konkurencji na rynkach lokalnych. Większe korzyści mikroekonomiczne wynikające z rozprzestrzeniania się bezpośrednich inwestycji zagranicznych, pozytywnych powiązań i presji konkurencyjnej są bardziej prawdopodobne w gospodarkach o dobrze rozwiniętych rynkach finansowych, na których lokalne firmy mogą reagować na te szanse i zagrożenia $z$ tytułu wzrostu konkurencji poprzez inwestycje zwiększające ich produktywność.

$\mathrm{Na}$ rysunku 6 pokazujemy roczne strumienie napływu, a na rysunku 7 roczne strumienie odpływu FDI w skali: globalnej, OECD i EU jako procent PKB (odpowiednio: światowego, OECD i EU). Największe znaczenie w relacji do PKB mają FDI w ramach EU. Wartość inwestycji bezpośrednich, które napłynęły w roku 2007 do krajów EU wynosiła 4,60\% ich PKB, podczas gdy wartość FDI rezydentów EU za granicą stanowiła w tym roku 7,00\% PKB. A więc rezydenci EU w większym stopniu są inwestorami bezpośrednimi niż biorcami 
inwestycji zagranicznych. Dla krajów OECD te same wskaźniki w 2007 roku odpowiednio wynoszą: napływ FDI - 3,10\% PKB; odpływ FDI - 4,20\% PKB. A więc ponownie rezydenci tych krajów w większym stopniu inwestują za granicą niż są beneficjentami inwestycji zagranicznych. Jednak różnica jest znacznie niższa w porównaniu z EU.

Rysunek 6. Napływ inwestycji bezpośrednich jako procent PKB

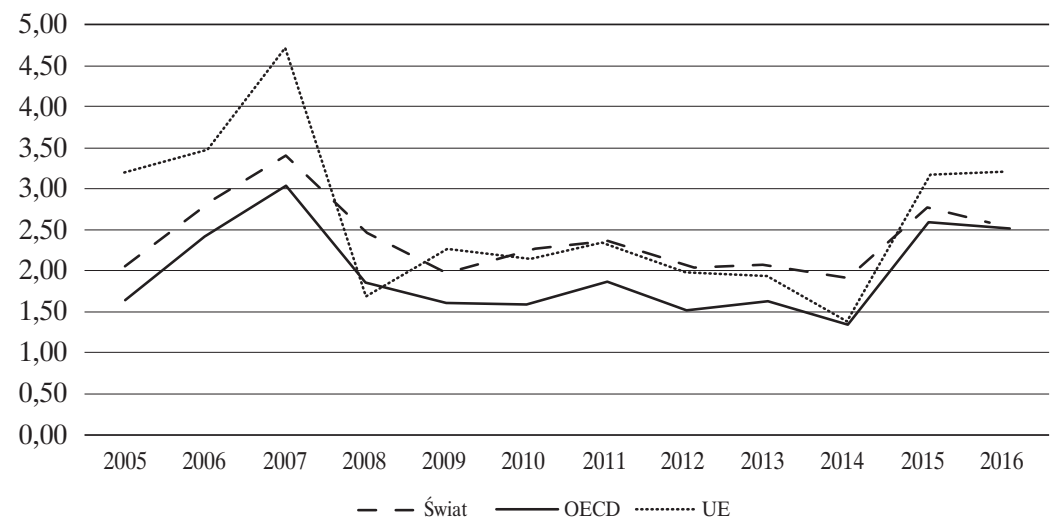

Źródło: opracowanie własne na podstawie danych OECD (www.oecd.org).

Rysunek 7. Napływ inwestycji bezpośrednich jako procent PKB

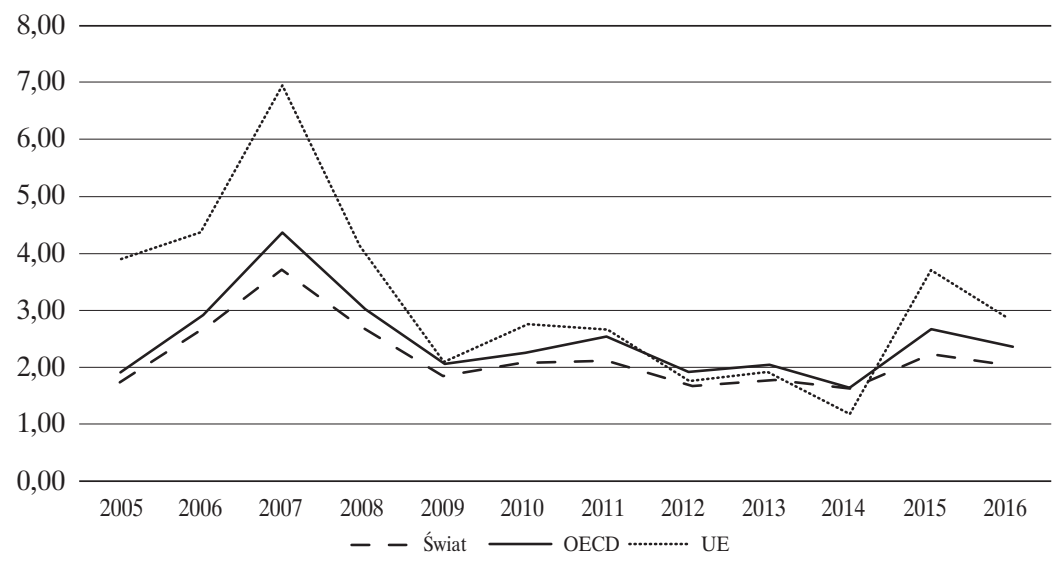

Źródło: opracowanie własne na podstawie danych OECD (www.oecd.org). 
Na rysunku 8 pokazujemy napływ FDI, na rysunku 9 zaś odpływ kapitału z trzech grup krajów OECD wyróżnionych w pierwszej części artykułu (wysoko rozwinięte, średnio rozwinięte i słabo rozwinięte). Jak poprzednio wszystkie strumienie są podawane w okresie 2005-2016. Warto zauważyć, że napływ i odpływ kapitału w ramach FDI jest bardzo wrażliwy na światowy cykl koniunkturalny, czego nie widać $\mathrm{w}$ grupie krajów średnio i słabo rozwiniętych. Napływ FDI wzrósł w okresie 2005-2007 z około 500 mld USD do 1100 mld USD. Wartość inwestycji bezpośrednich rezydentów krajów OECD za granicą wynosiła w 2007 roku 1,6 bln USD, co stanowiło $84 \%$ inwestycji bezpośrednich całego OECD i $71 \%$ światowych inwestycji bezpośrednich. Napływ FDI do krajów OECD wyniósł w tym roku 1,1 bln USD, co stanowiło 85\% wartości napływu FDI do całego OECD i 55\% wartości globalnych FDI w tym roku. Z powyższych wskaźników wynika, że podstawowe znaczenie w ramach OECD mają FDI między rezydentami 19 najbardziej rozwiniętych krajów świata. Rezydenci tych krajów są eksporterami netto do pozostałych krajów, co wyraża się w ujemnym saldzie FDI tej grupy krajów, przedstawionym na rysunku 10. W odwrotnej sytuacji są kraje średnio i słabo rozwinięte, które mają dodatnie saldo FDI. Szczególnym beneficjentem FDI jest grupa krajów najniżej rozwiniętych, której saldo FDI jest niemalże dwukrotnie wyższe w porównaniu z grupą krajów średnio rozwiniętych. Szczegółowe wyniki zaprezentowano w tabelach 2 i 3.

Rysunek 8. Napływ inwestycji bezpośrednich w trzech grupach krajów OECD przy uwzględnieniu poziomu rozwoju gospodarczego mierzonego PKB per capita w mln USD

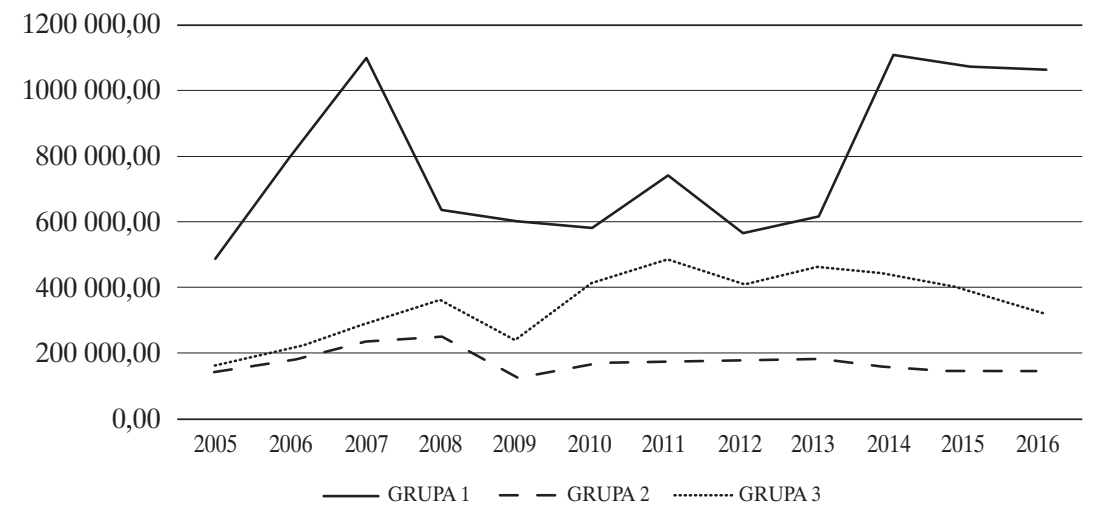

Źródło: opracowanie własne na podstawie danych OECD (www.oecd.org). 
Rysunek 9. Odpływ inwestycji bezpośrednich w trzech grupach krajów OECD przy uwzględnieniu poziomu rozwoju gospodarczego mierzonego PKB per capita w mln USD

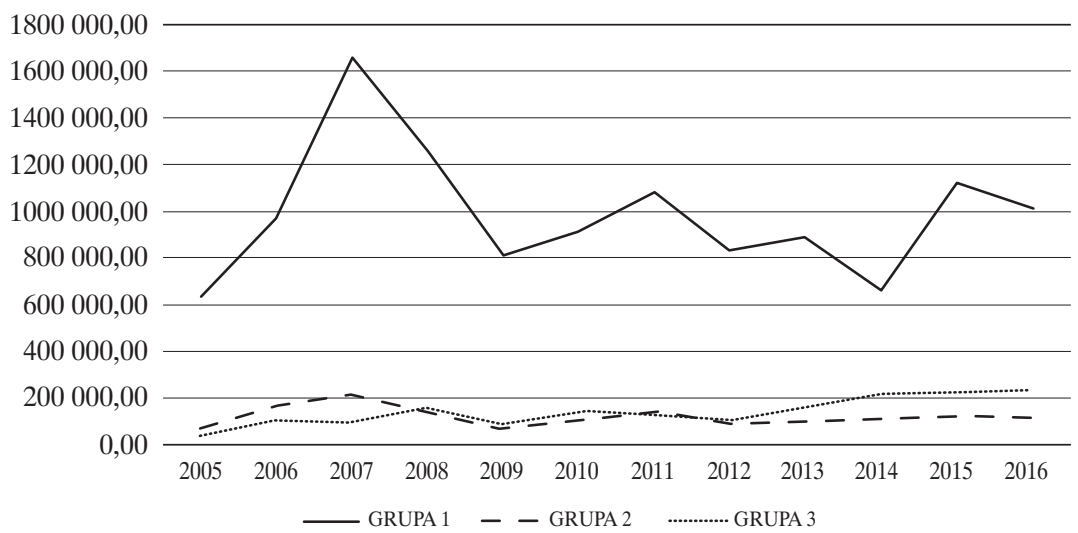

Źródło: opracowanie własne na podstawie danych OECD (www.oecd.org).

Rysunek 10. Saldo inwestycji bezpośrednich w trzech grupach krajów OECD przy uwzględnieniu poziomu rozwoju gospodarczego mierzonego PKB per capita

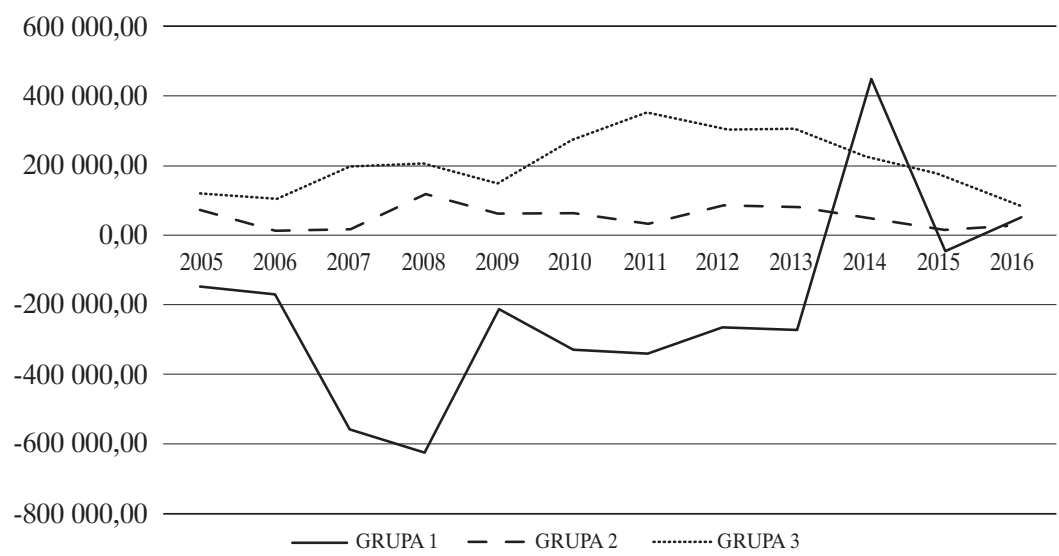

Źródło: opracowanie własne na podstawie danych OECD (www.oecd.org).

W badaniu przeprowadzonym przez R. Cezar i O.R. Escobar (2015) przeanalizowano powiązania między bezpośrednimi inwestycjami zagranicznymi a odległością instytucjonalną ${ }^{3}$. Zweryfikowali oni, w jaki sposób dystans instytucjonalny wpływa na bezpośrednie inwestycje zagraniczne i pokazali, że odległości instytucjonalne zmniejszają prawdopodobieństwo, że firma zainwestuje

3 Różnice pomiędzy regulacjami i instytucjami regulującymi. 
w obcym kraju, co ma związek również z wielkością inwestycji, które podejmie. Badanie przeprowadzone na danych OECD wskazuje, że aktywność FDI maleje wraz z odległością instytucjonalną. Ponadto zauważają, że firmy z gospodarek rozwiniętych łatwiej adaptują się do dystansu instytucjonalnego niż firmy z gospodarek rozwijających się.

Tabela 2. Napływ inwestycji bezpośrednich z grup I, II i III do grup I i II w mln USD

\begin{tabular}{|c|r|r|r|r|r|r|}
\hline $\begin{array}{c}\text { Kraje } \\
\text { przyjmujące }\end{array}$ & \multicolumn{2}{|c|}{ GRUPA I } & \multicolumn{2}{c|}{ GRUPA II } & \multicolumn{2}{c|}{ GRUPA III } \\
\hline $\begin{array}{c}\text { Kraje } \\
\text { wysylające }\end{array}$ & GRUPA I & GRUPA II & GRUPA I & GRUPA II & GRUPA I & GRUPA II \\
\hline 2005 & 68341 & 22728 & 11933 & 3156 & 174 & 144 \\
\hline 2006 & 50024 & 20339 & 5902 & 2768 & 3206 & 83 \\
\hline 2007 & 123325 & 28132 & 10864 & 5695 & 906 & 35 \\
\hline 2008 & 60463 & 24204 & -11864 & 6570 & 279 & 282 \\
\hline 2009 & 69549 & 20932 & 2693 & 6074 & -1619 & 329 \\
\hline 2010 & 91608 & 25737 & 2507 & 4938 & -98 & 230 \\
\hline 2011 & 355466 & 78538 & 16896 & 7327 & 1589 & -2103 \\
\hline 2012 & 337360 & 59715 & 15593 & 3251 & 3412 & 303 \\
\hline 2013 & 637943 & 102548 & 77210 & 5694 & 12347 & 1255 \\
\hline 2014 & 398755 & 78380 & 31463 & 13313 & 19822 & 1272 \\
\hline 2015 & 870877 & 40743 & 19141 & 10394 & 1575 & 395 \\
\hline 2016 & 709703 & 116074 & 25188 & 16292 & 7451 & 1071 \\
\hline
\end{tabular}

Źródło: opracowanie własne na podstawie danych OECD (www.oecd.org).

Tabela 3. Odpływ inwestycji bezpośrednich z grup I i II i III do grup I, II, III w mln USD

\begin{tabular}{|c|r|r|r|r|r|r|}
\hline $\begin{array}{c}\text { Kraje } \\
\text { przyjmujące }\end{array}$ & \multicolumn{2}{|c|}{ GRUPA I } & \multicolumn{2}{c|}{ GRUPA II } & \multicolumn{2}{c|}{ GRUPA III } \\
\hline $\begin{array}{c}\text { Kraje } \\
\text { wysylające }\end{array}$ & GRUPA I & GRUPA II & GRUPA I & GRUPA II & GRUPA I & GRUPA II \\
\hline 2005 & 93999.50 & 83.32 & 24061.65 & 425.89 & 7659.71 & 222.50 \\
\hline 2006 & 131022.97 & 355.27 & 30079.08 & 676.51 & 10372.79 & 134.14 \\
\hline 2007 & 198611.91 & 467.78 & 26477.75 & 1142.08 & 20750.17 & 288.89 \\
\hline 2008 & 87543.86 & 413.61 & 36568.71 & 925.55 & 19596.49 & -83.17 \\
\hline 2009 & 143029.68 & -63.04 & 17421.18 & 2170.64 & 4487.36 & 280.24 \\
\hline 2010 & 129460.87 & 1139.48 & 19266.27 & -139.63 & 6712.58 & $-3,75$ \\
\hline 2011 & 405668.24 & 42001.20 & 21922.29 & 3332.72 & 10119.23 & 194.26 \\
\hline
\end{tabular}


cd. tabeli 2

\begin{tabular}{|c|c|r|r|r|r|r|}
\hline $\begin{array}{c}\text { Kraje } \\
\text { przyjmujące }\end{array}$ & \multicolumn{2}{|c|}{ GRUPA I } & \multicolumn{2}{c|}{ GRUPA II } & \multicolumn{2}{c|}{ GRUPA III } \\
\hline $\begin{array}{c}\text { Kraje } \\
\text { wysylające }\end{array}$ & GRUPA I & GRUPA II & GRUPA I & GRUPA II & GRUPA I & GRUPA II \\
\hline 2012 & 314797.58 & 1647.07 & 35197.69 & 2186.47 & 14596.41 & 428.15 \\
\hline 2013 & 567517.90 & 7785.97 & 79522.83 & 8911.37 & 27716.08 & 878.87 \\
\hline 2014 & 491038.61 & 24053.40 & 59599.13 & 21673.86 & -96.58 & 971.46 \\
\hline 2015 & 774445.08 & 8577.26 & 36172.76 & 8936.24 & 15702.54 & 1980.20 \\
\hline 2016 & 676821.75 & 97956.83 & 72499.14 & 6566.18 & 9926.59 & 33.81 \\
\hline
\end{tabular}

Źródło: opracowanie własne na podstawie danych OECD (www.oecd.org).

Badania M. Irandoust (2016) przeprowadzone na grupie krajów bałtyckich pomiędzy FDI oraz zmianami strukturalnymi wykazały, że poprzez promowanie wzrostu i reform strukturalnych kraje będące beneficjentami mogą zachęcać do napływu bezpośrednich inwestycji zagranicznych, co z kolei może wpływać na wzrost. Wskazali ponadto na występowanie sprzężenia zwrotnego pomiędzy tymi dwiema zmiennymi.

Rysunek 11. Saldo inwestycji bezpośrednich w podziale na sektory w I grupie krajów w mln USD

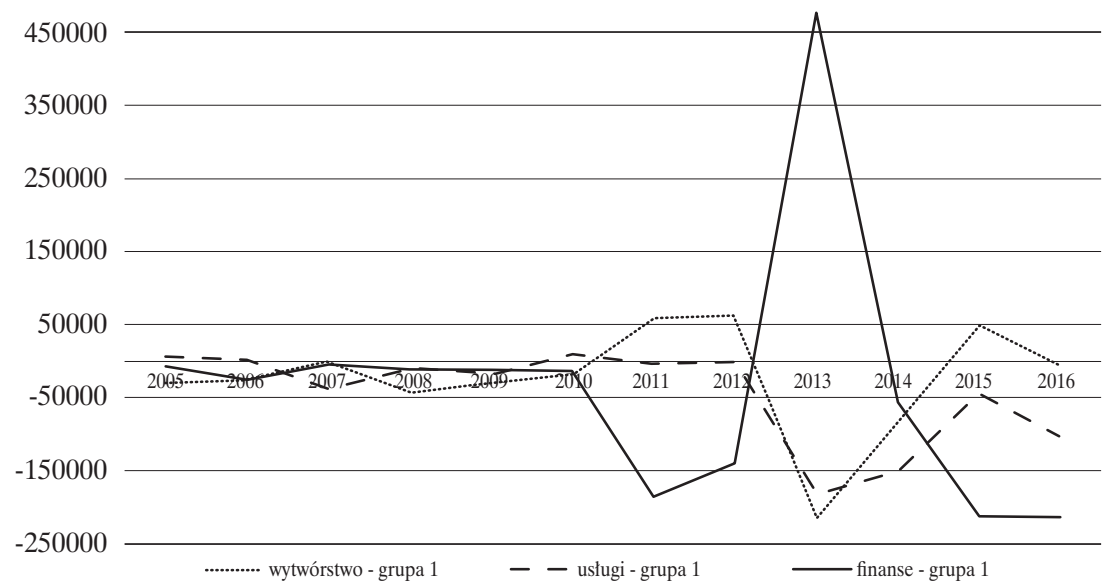

Źródło: opracowanie własne na podstawie danych OECD (www.oecd.org). 
Przeprowadzona analiza jest zgodna z założeniami Nowej Ekonomii Strukturalnej (Lin, 2010; 2012). Okazało się, że w zależności od poziomu rozwoju gospodarczego optymalna struktura przemysłowa ulega zmianom. Zmianom ulega również forma, z punktu widzenia gałęzi gospodarki, napływu środków z inwestycji bezpośrednich. W zaistniałej sytuacji można domniemywać, że w zależności od poziomu rozwoju gospodarczego kraje powinny inwestować zarówno w „miękką”, jak i w „twardą” infrastrukturę. Jednocześnie, zgodnie z założeniem wspomnianej teorii, można domniemywać, że w procesie ciągłości następuje ciagły wzrost gospodarczy przedstawiony przez nas jako teoria „wyścigu krajów”. Zmiana w zależności od rodzaju sektora, w którym dokonywane są inwestycje bezpośrednie powoduje stopniowy wzrost gospodarczy. W związku z tym kraje powinny dostosowywać swoje inwestycje w dany sektor w zależności od poziomu rozwoju gospodarczego. Ponadto wpływ kryzysu finansowego na alokację inwestycji bezpośrednich w poszczególnych gospodarkach pokazuje, że na każdym danym etapie rozwoju rynek jest podstawowym mechanizmem efektywnego alokowania zasobów. W skutek tego wraz ze wzrostem poziomu gospodarczego, zgodnie z Nową Ekonomią Strukturalną, gospodarki wymagają modernizacji przemysłowej i odpowiednich ulepszeń w „twardej” i „miękkiej” infrastrukturze na każdym etapie. Taka modernizacja pociąga za sobą znaczne efekty zewnętrzne dla kosztów transakcyjnych firm i zwrotów z inwestycji kapitałowych. W związku z tym, oprócz skutecznego mechanizmu rynkowego, rząd powinien odgrywać aktywną rolę w ułatwianiu modernizacji przemysłowej i ulepszaniu infrastruktury.

Przeprowadzone badania wskazują na dwie gospodarki o szczególnym zainteresowaniu w tym względzie, tj. Chiny i Indie, zarówno ze względu na swoją wielkość, jak i bardzo szybki wzrost. R. Dekle i G. Vandenbroucke (2012, s. 119-135) badali strukturalną transformację w Chinach w latach 1978-2003. Odkryli, że zróżnicowany sektorowy wzrost produktywności i zmniejszenie względnej wielkości chińskiego rządu spowodowały większość transformacji strukturalnej, ale spowolnity ruch w rolnictwie. V. Rubina (2012, s. 163-177) badała transformację strukturalną w Indiach w latach 1980-2005 i stwierdziła, że wzrost był najszybszy w usługach. Udowodniła, że model trójsektorowy może uwzględniać zmiany w sektorowej wartości dodanej, ale nie w udziałach w zatrudnieniu. C.M. Betts i in. (2011), M. Sposi (2011) i M. Teignier (2012) twierdzą, że handel międzynarodowy przyspieszył przejście gospodarki z rolnictwa do przemysłu i usług. Teignier (2012) dowiódł, że efekt międzynarodowych inwestycji odegrałby jeszcze większą rolę, gdyby Korea Południowa nie wprowadziła jednocześnie polityki ochrony rolnictwa. 
Praca D.W. Jorgenson i M.P. Timmer (2011, s. 1-29), opierająca się na badaniu Unii Europejskiej, Japonii i USA, wykazuje znaczną niejednorodność usług. Finanse i usługi biznesowe odznaczają się niskim wzrostem wydajności i zwiększają udział w zatrudnieniu i PKB, przy czym usługi dystrybucyjne mają szybki wzrost produktywności i stały udział. M. Duarte i D. Restuccia (2010, s. 129-173) studiują różnice między tradycyjnymi ${ }^{4}$ i nietradycyjnymi usługami. W przypadku usług tradycyjnych zauważają, że cena względna wzrasta, a realny udział wydatków maleje wraz z przychodami, podczas gdy w przypadku usług nietradycyjnych są przeciwne. D. Lagakos i M.E. Waugh (2013, s. 948-980) twierdzą, że uwzględnienie heterogenicznej jakości pracy w różnych sektorach dowodzi, że kraje ubogie wydają się mieć szczególnie niską wydajność pracy w rolnictwie.

B. Herrendorf, R. Rogerson, A. Valentinyi (2014, s. 855-941) wskazują, że nieodpowiednio dobrane polityki strukturalne mogą zniekształcać alokację zasobów w różnych sektorach. Zgodnie z Nową Ekonomią Strukturalną transformacja strukturalna powinna dążyć przy wykorzystaniu interwencji państwa do rozwoju specyficznych sektorów mających największy potencjał rozwoju (Ketels, 2017). Założenia dotyczące rentowności w ekonomii neoklasycznej można złagodzić, analizując kwestie rozwoju i transformacji w gospodarkach socjalistycznych, transformacyjnych i rozwijających się (Lin, 2015).

Rysunek 12. Saldo inwestycji bezpośrednich w podziale na sektory w II grupie krajów w mln USD

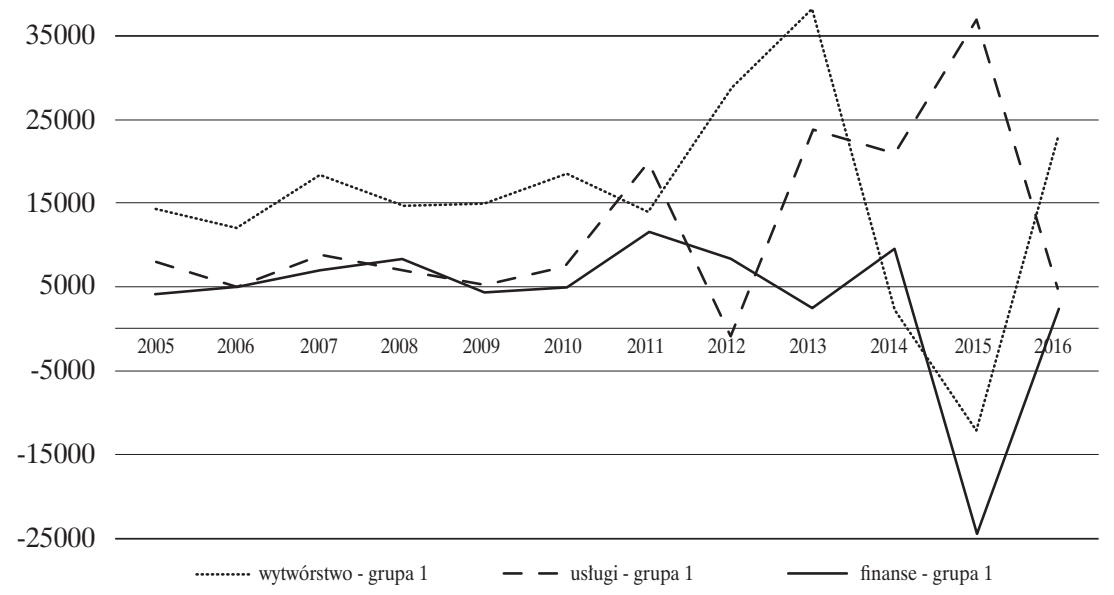

Źródło: opracowanie własne na podstawie danych OECD (www.oecd.org).

4 Tj. usługi tradycyjne to: usługi domowe i edukacja, zdrowie, mieszkalnictwo, nietradycyjne zaś to: komunikacja, usługi transportowe, ubezpieczeniowe i finansowe oraz usługi rekreacyjne i kulturalne. 
Następnie postanowiono zweryfikować wzajemne zależności pomiędzy saldem inwestycji bezpośrednich a realną stopą wzrostu PKB i odwrotnie. W celu przeprowadzenia weryfikacji wspomnianej zależności zebrano dane roczne z Banku Światowego dla lat 1970-2017 dla 165 krajów. Do badania wykorzystano statyczne modele panelowe. Do weryfikacji poprawności wyboru modelu zastosowano test Hausamana, Breuscha-Pagana. Wybór modelu panelowego podyktowany był jednoczesnym posiadaniem cech danych przekrojowych, czyli danych dla krajów oraz szeregów czasowych. Model prezentujący wpływ realnej stopy wzrostu PKB na saldo inwestycji bezpośrednich do PKB został zaprezentowany poniżej:

$$
f d i_{i t}=\alpha+p k b_{i t}+u_{i t}+e_{i t}
$$

$f d i_{i t}$ - stosunek salda inwestycji bezpośrednich do PKB $i$-tego kraju w okresie $t$, $p k b_{i t}$ - realna stopa wzrostu PKB $i$-tego kraju w okresie $t$, $\alpha$ - stała, $u_{i t}$ - błąd losowy zawierający stałe w czasie nieobserwowane charakterystyki, $e_{i t}-$ błąd czysto losowy.

Natomiast model prezentujący wpływ salda inwestycji bezpośrednich na realną stopę wzrostu PKB został zaprezentowany poniżej:

$$
p k b_{i t}=\alpha+f d i_{i t}+u_{i t}+e_{i t}
$$

W tabeli 4 zaprezentowano wyniki estymacji.

Wyniki estymacji przeprowadzone dla testu Hausmana sugerują poprawność wykorzystania statycznego modelu panelowego z efektami zmiennymi. Natomiast otrzymane wyniki dla testu Bresucha-Pagana wskazują na zasadność wykorzystania modelu panelowego wobec modelu liniowego w obu przypadkach. Będąc świadomi słabego dopasowania modelu, nie dokonujemy bezpośredniej analizy otrzymanych wyników. Naszym celem była jedynie weryfikacja istotności wzajemnych zależności pomiędzy saldem inwestycji bezpośrednich a realną stopą wzrostu PKB i odwrotnie. Przeprowadzone badanie dowiodło wysoce istotnej statystycznie zależności pomiędzy obiema zmiennymi. Niski poziom dopasowania modelu należy tłumaczyć wpływem innych istotnych czynników oddziałujących zarówno na saldo inwestycji bezpośrednich, jak i realną stopę wzrostu PKB. Otrzymane wyniki symulacji są zgodne z badaniami C.K. Volos, I.M. Kyprianidis, I.N. Stouboulos (2015, s. 1-7). 
Tabela 4. Wyniki estymacji wpływu realnej stopy wzrostu PKB na saldo inwestycji bezpośrednich (1) oraz salda inwestycji bezpośrednich na realną stopę wzrostu PKB

\begin{tabular}{|c|c|c|c|c|}
\hline \multirow{2}{*}{ Zmienna zależna } & \multicolumn{2}{|c|}{ FDI netto (1) } & \multicolumn{2}{|c|}{ Realna stopa wzrostu PKB (2) } \\
\hline & Coef. & $P>z$ & Coef. & $\mathbf{P}>\mathbf{z}$ \\
\hline Zmienna niezależna & .123695 & 0.000 & .0306341 & 0.000 \\
\hline$\alpha$ & 3.500842 & 0.000 & 3.704615 & 0.000 \\
\hline Liczba obserwacji & \multicolumn{2}{|c|}{5911} & \multicolumn{2}{|c|}{5911} \\
\hline Liczba grup & \multicolumn{2}{|c|}{165} & \multicolumn{2}{|c|}{165} \\
\hline Test F & \multicolumn{2}{|c|}{0.0000} & \multicolumn{2}{|c|}{0.0000} \\
\hline Hausman & \multicolumn{2}{|c|}{0.1306} & \multicolumn{2}{|c|}{0.1947} \\
\hline $\mathrm{BP}$ & \multicolumn{2}{|c|}{0.0000} & \multicolumn{2}{|c|}{0.0000} \\
\hline \multicolumn{5}{|l|}{$\mathrm{R}$ squared } \\
\hline Wewnątrz & \multicolumn{2}{|c|}{0.0034} & \multicolumn{2}{|c|}{0.0034} \\
\hline Pomiędzy & \multicolumn{2}{|c|}{0.0240} & \multicolumn{2}{|c|}{0.0240} \\
\hline Całość & \multicolumn{2}{|c|}{0.0070} & \multicolumn{2}{|c|}{0.0070} \\
\hline Model & \multicolumn{2}{|c|}{ z efektami zmiennymi } & \multicolumn{2}{|c|}{ z efektami zmiennymi } \\
\hline
\end{tabular}

Legenda: liczba grup - liczba krajów poddanych analizie; test $\mathrm{F}$ - test Fishera; Hausman - test Hausmana; $\mathrm{BP}$ - test Breuscha - Pagana; R squared - skorygowany $\mathrm{R}^{2}$ : wewnątrz - skorygowany $\mathrm{R}^{2}$ wewnątrz grupy krajów; pomiędzy - skorygowany $\mathrm{R}^{2}$ pomiędzy grupami krajów; całość - łączny skorygowany $\mathrm{R}^{2}$. Źródło: opracowanie własne.

K. Dellis, D. Sondermann, I. Vansteenkiste (2017) wskazali na wpływ zmian strukturalnych, takich jak koszty pracy, wielkość rynku docelowego (zgodnie z jego wartością), działalność gospodarcza, otwartość handlu kraju będącego beneficjentem oraz jego tendencja do opodatkowania. S. Estrin i M. Uvalic (2013) dowiedli, że przy uwzględnieniu wielkości gospodarki, odległości, jakości instytucjonalnej i perspektyw członkostwa w UE, kraje Bałkanów Zachodnich charakteryzują się niższym napływem bezpośrednich inwestycji zagranicznych. Kwestie te mają duże znaczenie polityczne dla gospodarek bałkańskich.

\section{Podsumowanie}

Jesteśmy w pełni przekonani, że bezpośrednie inwestycje zagraniczne nie są jedynym, ani nawet głównym, czynnikiem wpływającym na wzrost gospodarczy, jak również tempo wzrostu gospodarczego nie w pełni determinuje napływ i odpływ tych inwestycji. Świadczą o tym niskie współczynniki korelacji wielorakiej w obu zaprezentowanych modelach. Naszym celem nie było jednak pełne 
wyjaśnienie determinantów tych dwóch zmiennych. Do tego celu należałoby zastosować modele wieloczynnikowe. Jednak oba modele jednoczynnikowe udowadniają hipotezę o istnieniu dodatniego sprzężenia zwrotnego pomiędzy tymi zmiennymi. Napływ bezpośrednich inwestycji pozytywnie wpływa na tempo wzrostu gospodarczego, a wzrost gospodarczy zachęca inwestorów zagranicznych do inwestowania. Oznacza to, że FDI działają procyklicznie. Wspomagają wzrost gospodarczy, ale również pogłębiają recesje i spadek PKB. Jeżeli zahamowanie bądź spadek tempa wzrostu gospodarczego następuje na skutek szoków wewnętrznych, bądź zewnętrznych to reakcja inwestorów zagranicznych pogłębia ten spadek. Zjawisko to bardzo wyraźnie wystąpiło w roku 2018 w przypadku Argentyny i Turcji.

Zjawisko to zaobserwowano już wcześniej w relacji kredytów bankowych i wzrostu gospodarczego. W ramach Bazylei III wprowadzono dla przeciwdziałania procyklicznemu charakterowi kredytów specjalne antycykliczne bufory kapitałowe w obliczaniu współczynnika wypłacalności. W przeciwieństwie jednak do sektora bankowego, FDI nie są regulowane ani przez państwa pochodzenia kapitału, ani przez państwa goszczące.

\section{Bibliografia}

Alfaro, L. i Chauvin, J. (2017). Foreign Direct Investment, Finance, and Economic Development. Harvard Business School Working Papers.

Betts, C.M., Giri, R. i Rubina, V. (2011). Trade, Reform, and Structural Transformation in South Korea. University of Southern California Working Paper.

Cezar, R. i Escobar, O.R. (2015). Institutional Distance and Foreign Direct Investment. Banque de France, December.

Dekle, R., Vandenbroucke, G. (2012). A Quantitative Analysis of China's Structural Transformation. Journal of Economic Dynamics and Control, 36, 119-135.

Dellis, K., Sondermann, D. i Vansteenkiste, I. (2017). Determinants of FDI inflows in advanced economies: Does the quality of economic structures matter? European Central Bank Working Paper, No. 2066.

Duarte, M. i Restuccia, D. (2010). The Role of the Structural Transformation in Aggregate Productivity. Quarterly Journal of Economics, 125, 129-173.

Estrin, S. i Uvalic, M. (2013). Foreign direct investment into transition economies: Are the Balkans different? London School of Economics Europe in Questions Working Paper, No. 63.

Herrendorf, B., Rogerson, R. i Valentinyi, A. (2014). Growth and Structural Transformation. Handbook of Economic Growth, 2, 855-941.

https://data.oecd.org

Irandoust, M. (2016). Structural changes, FDI, and economic growth: evidence from the Baltic states. Journal of Economic Structures, 5(14). 
Jorgenson, D.W. i Timmer, M.P. (2011). Structural Change in Advanced Nations: A New Set of Stylised Facts. Scandinavian Journal of Economics, 113, 1-29.

Ketels, C. (2017). Structural transformation: a competitiveness-based view. African Development Bank Group Working Papers, No. 258.

Lagakos, D. i Waugh, M.E. (2013). Selection, Agriculture, and Cross-Country Productivity Differences. The American Economic Review, 103(2), 948-980.

Lin, J.Y. (2010). New Structural Economics A Framework for Rethinking Development. World Bank Policy Research Working Paper, No. 5197.

Lin, J.Y. (2012). New Structural Economics. A Framework for Rethinking Development and Policy. World Bank.

Lin, J.Y. (2017). New Structural Economics and 2017 industrial policies catching-up economics. W: J.Y. Lin, A.Z. Nowak (red.), New Structural Economics for less advanced countries. Warszawa: Wydawnictwo Naukowe Wydziału Zarządzania UW.

Lin, J.Y. (2015). The Washington Consensus revisited: a new structural economics perspective. Journal of Economic Policy Reform, 18.

Rubina, V. (2012). Can Total Factor Productivity Explain Value Added Growth in Services. Journal of Development Economics, 99, 163-177.

Sposi, M. (2011). Evolving Comparative Advantage, Structural Change, and the Composition of Trade. University of Iowa Working Paper.

Teignier, M. (2012). The Role of Trade in Structural Transformation. Universidad de Alicante Working Paper.

Volos, C.K., Kyprianidis, I.M. i Stouboulos, I.N. (2015). The Effect of Foreign Direct Investment in Economic Growth from the Perspective of Nonlinear Dynamics. Journal of Engineering Science and Technology Review, 8(1), 1-7. 


\section{Prawne otoczenie dla inwestycji zagranicznych w Polsce}

Swoboda przepływu kapitału oraz szeroko rozumianych dóbr i usług realizowana jest przez państwa za pomocą szeregu instrumentów prawnych, wyznaczających stopień otwarcia gospodarki danego kraju dla uczestnictwa w niej podmiotów zagranicznych, a szczególnie możliwości podejmowania i prowadzenia przez te podmioty działalności gospodarczej, zatrudnienia, dokonywania inwestycji, obrotu nieruchomościami, obrotu dewizowego. Kształt przepisów prawnych tworzących ramy normatywne dla aktywności gospodarczej inwestorów zagranicznych w danym kraju jest elementem definiującym stopień dostępu do danego rynku, poziom jego internacjonalizacji i liberalizacji. Celem niniejszego artykułu jest analiza regulacji prawa polskiego w zakresie warunków prawnych podjęcia i wykonywania działalności gospodarczej na terytorium Rzeczpospolitej Polskiej przez osoby zagraniczne i przedsiębiorców zagranicznych. Temat ten jest szczególnie aktualny w związku ze zmianami wprowadzonymi w tym obszarze przez obowiązującą od niedawna Konstytucję Biznesu.

Słowa kluczowe: osoba zagraniczna, przedsiębiorca zagraniczny, działalność gospodarcza, transgraniczna działalność usługowa, Konstytucja Biznesu.

\section{Uwagi wprowadzające}

Zjawisko swobodnego przepływu produktów, technologii, kapitału oraz przemieszczania się instytucji, przedsiębiorców i ludzi jest elementem charakterystycznym i pozostającym w ścisłym związku z postępującym procesem umiędzynarodowienia stosunków społeczno-gospodarczych na płaszczyźnie rynków, branż i przedsiębiorstw. Konsekwencją działania rynku w skali globalnej jest zmniejszenie barier w gospodarce światowej, w szczególności w handlu międzynarodowym, ale także stopniowe znoszenie ograniczeń w przepływie kapitału i zasobów finansowych. W tym kontekście zniesienie przeszkód dla bezpośrednich inwestycji zagranicznych tak, aby podmioty zagraniczne konkurowały z krajowymi na równych zasadach stanowi jedną z głównych tendencji występujących w gospodarce światowej (Nowak, 2017, s. 19-20; Kotyński, 2005, s. 9 i nast.; Hejduk i Bakalarczyk, 2013, s. 11 i nast.). Dzięki procesowi globalizacji oraz traktatom międzynarodowym w obszarze wolnego handlu państwa otwie- 
rają się na wymianę handlową oraz inwestycje zagraniczne, a zasada wolnego handlu stanowi jedną z podstaw działania Unii Europejskiej (Nowak, 2017a, s. 27). Zgodnie z preambułą dyrektywy Parlamentu Europejskiego i Rady dotyczącej usług na rynku wewnętrznym (Dz. Urz. UE L 276 z 27.12.2006), Unia Europejska dąży do tworzenia coraz ściślejszych związków między państwami i narodami Europy oraz do zapewnienia postępu gospodarczego i społecznego. Zgodnie z postanowieniami Traktatu ustanawiającego Wspólnotę Europejską ${ }^{1}$ rynek wewnętrzny obejmuje obszar bez granic wewnętrznych, w którym zapewniony jest swobodny przepływ usług, swoboda przedsiębiorczości oraz swoboda świadczenia usług wewnątrz Wspólnoty. Konkurencyjny rynek usług ma istotne znaczenie przy wspieraniu wzrostu gospodarczego i tworzeniu miejsc pracy w Unii Europejskiej. W preambule stwierdza się ponadto, że obecnie liczne bariery na rynku wewnętrznym uniemożliwiają usługodawcom, w szczególności małym i średnim przedsiębiorstwom, rozszerzanie swojej działalności poza granice ich krajów i pełny udział w korzyściach z rynku wewnętrznego. Osłabia to globalną konkurencyjność usługodawców z Unii Europejskiej. Wolny rynek zobowiązujący państwa członkowskie do znoszenia ograniczeń w transgranicznym świadczeniu usług, przy jednoczesnej większej przejrzystości oraz pełniejszej informacji, oznaczałby dla konsumentów większy wybór i lepszą jakość usług po niższych cenach².

Zwiększanie skali międzynarodowych obrotów usługami jest efektem zintensyfikowanych w czasie globalizacji procesów deregulacyjnych, postępu technicznego oraz wzrostu liczbowego klasy średniej w krajach o gospodarkach wschodzących i krajach rozwijających się (Budnikowski, 2017, s. 29). Proces globalizacji oznacza wejście w nową jakościowo fazę umiędzynarodowienia działalności gospodarczej, realizowaną na płaszczyźnie rynków, sektorów i przedsiębiorstw (Budnikowski, 2017, s. 599), a z perspektywy internacjonalizacji obrotów gospodarczych podstawowe znaczenie posiada kwestia zniesienia barier dla inwestycji zagranicznych w danym kraju, pozwalających zmniejszać międzynarodowe dysproporcje w wyposażeniu w kapitał. Inwestycje zagraniczne, choć nie wpływają w jednakowy sposób na wszystkie mierniki koniunktury gospodarczej, stanowią jednak jeden z motorów wzrostu gospodarczego, przyczyniając się do powiększenia zasobów kapitału danej gospodarki, co wiąże się ze wzrostem produkcyjności i płac oraz zwiększenia dostępności do nowoczesnych technologii (Mankiw i Taylor, 2016, s. 80; Burda i Wyplosz, 2013, s. 171; Begg, Vernasca, Fischer i Dornbusch, 2014,

Obecnie Traktatu o funkcjonowaniu Unii Europejskiej (TFUE).

2 Dyrektywa 2006/123/WE Parlamentu Europejskiego i Rady z dnia 12 grudnia 2006 r. dotycząca usług na rynku wewnętrznym (Dz.Urz. UE L 276 z 27.12.2006), zwana również dyrektywą usługową. 
s. 480 i nast.). Warto również zaznaczyć rolę zwiększania inwestycji zagranicznych i kapitału obcego jako instrumentu wychodzenia ze światowego kryzysu finansowego w gospodarkach światowych ostatnich lat (Nowak, 2015, s. 590).

Swoboda przepływu szeroko rozumianych usług jest realizowana przez państwa za pomocą szeregu instrumentów prawnych, wyznaczających stopień otwarcia gospodarki danego kraju dla uczestnictwa w niej podmiotów zagranicznych (szerzej o podmiotach gospodarki światowej zob. Orłowska i Żołądkiewicz, 2012, s. 42 i nast.), w szczególności możliwości podejmowania i prowadzenia przez te podmioty działalności gospodarczej, możliwości zatrudnienia, dokonywania inwestycji, obrotu nieruchomościami, obrotu dewizowego (Budnikowski, 2017, s. 36). Kształt przepisów prawnych tworzących ramy normatywne dla wykonywania działalności gospodarczej w danym kraju przez przedsiębiorców zagranicznych jest elementem definiującym stopień dostępu do danego rynku, poziom jego internacjonalizacji i liberalizacji. Wyznaczone przez normodawcę ramy regulacyjne stanowią podstawę dla ekonomicznej analizy gospodarki oraz ustalają kierunki polityki gospodarczej państwa w tym zakresie.

\section{Konstytucja Biznesu}

W dniu 30 kwietnia 2018 r. wszedł w życie pakiet ustaw określanych jako Konstytucja Biznesu, przeprowadzających gruntowną reformę polskiego prawa gospodarczego. Zmiany wprowadzone przez Konstytucję Biznesu stanowią najgłębszą i najbardziej kompleksową po 1989 roku rekonstrukcję otoczenia gospodarczego, w którym funkcjonuje przedsiębiorca na polskim rynku. Celem reformy jest poprawa warunków prawno-instytucjonalnych, w których działają przedsiębiorcy poprzez urzeczywistnienie konstytucyjnej zasady wolności gospodarczej oraz stworzenie partnerskich relacji przedsiębiorca - państwo (zasada „co nie jest przez prawo zakazane jest dozwolone”, klauzula pewności prawa, reguła domniemania uczciwości przedsiębiorcy, rozstrzygania wątpliwości faktycznych na jego korzyść, przyjazna interpretacja przepisów prawa, zasada rozstrzygania wątpliwości prawnych na korzyść przedsiębiorcy, reguła pogłębiania zaufania, proporcjonalności, bezstronności i równego traktowania, czy wreszcie zasada odpowiedzialności urzędników za naruszenie prawa, pewności prawa i przewidywalności rozstrzygnięć organów państwa, współdziałania organów w celu pełnego wyjaśnienia sytuacji przedsiębiorcy, odformalizowanie komunikacji między urzędem a przedsiębiorcą). Celem Konstytucji Biznesu jest również wsparcie przedsiębiorczości, w tym stworzenie przyjaznych warunków 
prawnych do rozpoczynania działalności gospodarczej, zmniejszenie tzw. szarej strefy, zapewnienie wsparcia instytucjonalnego dla przedsiębiorców poprzez powołanie Rzecznika Małych i Średnich Przedsiębiorców. Główną osią zmian jest nowa ustawa - Prawo przedsiębiorców ${ }^{3}$, zastępująca dotąd obowiązująca ustawę o swobodzie działalności gospodarczej ${ }^{4}$. Nowa ustawa w sposób systemowy określa podstawy ustroju gospodarczego Polski, stanowiąc zbiór fundamentalnych zasad obrotu gospodarczego, określa pozycję prawną przedsiębiorcy oraz obowiązki państwa wobec przedsiębiorców. Szczegółowe zmiany wprowadzone ustawą - Prawo przedsiębiorców były szeroko opisywane, wśród nich na szczególną uwagę zasługują uproszczenia dla drobnej działalności i osób dopiero organizujących działalność gospodarczą. Drobna działalność zarobkowa będzie mogła być prowadzona w sposób wolny, bez konieczności wpisu do CEIDG, osoba ją wykonująca nie będzie otrzymywała numeru Regon. Osoby fizyczne rozpoczynające wykonywanie działalności gospodarczej zwolnione są z obowiązku odprowadzania składek na ubezpieczenie społeczne przez 6 miesięcy. Ustawa wprowadza uproszczenia w zakresie reglamentacji działalności gospodarczej. Dotychczasowe zgody i licencje, jako oddzielne formy reglamentacji, przestają istnieć. Pozostają trzy formy ograniczeń: działalność wymagająca koncesji, działalność wymagająca zezwolenia i działalność regulowana. Istotne są również zmiany ograniczające kontrolę działalności gospodarczej.

Konstytucja Biznesu, poza nową ustawą - Prawo przedsiębiorców, obejmuje również: ustawę o Rzeczniku Małych i Średnich Przedsiębiorców5; ustawę o Centralnej Ewidencji i Informacji o Działalności Gospodarczej i Punkcie Informacji dla Przedsiębiorcy6; ustawę - Przepisy wprowadzające; ustawę - Prawo przedsiębiorców; inne ustawy dotyczące działalności gospodarczej ${ }^{7}$ oraz - co jest kluczowe z punktu widzenia przedmiotu niniejszej analizy - ustawę o zasadach uczestnictwa przedsiębiorców zagranicznych i innych osób zagranicznych w obrocie gospodarczym na terytorium Rzeczypospolitej Polskiej8.

3 Ustawa z dnia 6 marca 2018 r. - Prawo przedsiębiorców (Dz.U. 2018, poz. 646).

4 Ustawa z dnia 2 lipca 2004 r. o swobodzie działalności gospodarczej (t.j. Dz.U. 2017, poz. 2168 z późn.zm.), uchylona ustawą z dnia 6 marca 2018 r. - Przepisy wprowadzające ustawę - Prawo przedsiębiorców oraz inne ustawy dotyczące działalności gospodarczej (Dz.U. 2018, poz. 650).

5 Ustawa z dnia 6 marca 2018 r. o Rzeczniku Małych i Średnich Przedsiębiorców (Dz.U. 2018, poz. 648).

6 Ustawa z dnia 6 marca 2018 r. o Centralnej Ewidencji i Informacji o Działalności Gospodarczej i Punkcie Informacji dla Przedsiębiorcy (Dz.U. 2018, poz. 647 z późn. zm.).

7 Ustawa z dnia 6 marca 2018 r. - Przepisy wprowadzające ustawę - Prawo przedsiębiorców oraz inne ustawy dotyczące działalności gospodarczej (Dz.U. 2018, poz. 650).

8 Ustawa z dnia 6 marca 2018 r. o zasadach uczestnictwa przedsiębiorców zagranicznych i innych osób zagranicznych w obrocie gospodarczym na terytorium Rzeczypospolitej Polskiej (Dz.U. 2018, poz. 649 z późn. zm.). 
Dotychczasowe zasady dotyczące działalności gospodarczej osób zagranicznych na terytorium RP rozproszone były w kilku aktach prawnych. Zastosowana technika legislacyjna powodowała w efekcie brak przejrzystości odnośnie do kluczowych warunków funkcjonowania przedsiębiorców zagranicznych w krajowym obrocie gospodarczym. Warunki te określone były ustawą o swobodzie działalności gospodarczej, ustawą o świadczeniu usług na terytorium Rzeczypospolitej Polskiej ${ }^{9}$, ustawą o zasadach prowadzenia na terytorium Polskiej Rzeczypospolitej Ludowej działalności gospodarczej w zakresie drobnej wytwórczości przez zagraniczne osoby prawne i fizyczne ${ }^{10}$. Nowa ustawa o zasadach uczestnictwa przedsiębiorców zagranicznych i innych osób zagranicznych w obrocie gospodarczym na terytorium Rzeczypospolitej Polskiej (dalej: ustawa) scala w jednym akcie prawnym obowiązujące dotychczas regulacje prawne, w sposób kompleksowy i spójny ustalając warunki uczestnictwa przedsiębiorców zagranicznych w obrocie gospodarczym w Polsce. Powyższe powoduje, że zasady te stają się przejrzyste, bardziej przystępne i zrozumiałe dla podmiotów zagranicznych zainteresowanych dokonywaniem inwestycji na terytorium Polski. Omawiana ustawa w zakresie swojej regulacji wdraża dyrektywę 2006/123/WE Parlamentu Europejskiego i Rady dotyczącą usług na rynku wewnętrznym.

\section{Zasady wykonywania działalności gospodarczej na terytorium RP przez osoby zagraniczne oraz przedsiębiorców zagranicznych}

\subsection{Formy organizacyjnoprawne oraz warunki wykonywania działalności gospodarczej}

Osoby zagraniczne z państw członkowskich Unii Europejskiej lub państw członkowskich Europejskiego Porozumienia o Wolnym Handlu (EFTA) - strony umowy o Europejskim Obszarze Gospodarczym (państwa członkowskie) moga podejmować i wykonywać działalność gospodarczą na terytorium RP na takich

9 Ustawa z dnia 4 marca 2010 r. o świadczeniu usług na terytorium Rzeczypospolitej Polskiej (t.j. Dz.U. 2016, poz. 893 z późn.zm.), uchylona ustawą z dnia 6 marca 2018 r. - Przepisy wprowadzające ustawę - Prawo przedsiębiorców oraz inne ustawy dotyczące działalności gospodarczej (Dz.U. 2018, poz. 650).

10 Ustawa z dnia 6 lipca 1982 r. o zasadach prowadzenia na terytorium Polskiej Rzeczypospolitej Ludowej działalności gospodarczej w zakresie drobnej wytwórczości przez zagraniczne osoby prawne i fizyczne (t.j. Dz.U. 1989, poz. 27 z późn.zm.), uchylona ustawą z dnia 6 marca 2018 r. - Przepisy wprowadzające ustawę - Prawo przedsiębiorców oraz inne ustawy dotyczące działalności gospodarczej (Dz.U. 2018, poz. 650). 
samych zasadach, jak obywatele polscy. Przez osobę zagraniczną rozumie się osobę fizyczną nieposiadającą obywatelstwa polskiego, osobę prawną z siedzibą za granicą oraz jednostkę organizacyjną niebędącą osobą prawną posiadająca zdolność prawną, z siedzibą za granicą. Regułą tą objęte są podmioty prawa, bez względu na ich status prawnogospodarczy w państwie członkowskim.

Podobna zasada dotyczy obywateli innych państw niż państwa członkowskie, jeśli spełniają warunki określone w art. 4 ust. 2 ustawy (w szczególności jeśli posiadają zezwolenie na pobyt stały na terytorium RP, zezwolenie na pobyt rezydenta długoterminowego UE, zezwolenie na pobyt czasowy udzielony na wskazanych zasadach, status uchodźcy, ochronę uzupełniającą, korzystają w RP z ochrony czasowej, posiadają ważną Kartę Polaka i in.).

Pozostałe osoby zagraniczne mogą podejmować i wykonywać działalność gospodarczą na terytorium RP wyłącznie w formie spółki komandytowej, komandytowo-akcyjnej, z ograniczoną odpowiedzialnością i akcyjnej. Mogą również przystępować do takich spółek oraz obejmować bądź nabywać ich udziały lub akcje, o ile umowy międzynarodowe nie stanowią inaczej. Należy przy tym podkreślić, iż wymienione spółki są podmiotami prawa polskiego, działającymi w oparciu o przepisy prawa polskiego. Ustawa wyklucza możliwość podejmowania i wykonywania przez tę kategorię osób zagranicznych działalności gospodarczej na terytorium RP w innej formie organizacyjnoprawnej, np. w formie spółki jawnej czy partnerskiej oraz przystępowania do takich podmiotów.

Warto przy tym pamiętać, że nabycie lub objęcie przez cudzoziemca udziałów lub akcji w spółce handlowej z siedzibą na terytorium RP, a także każda inna czynność prawna dotycząca udziałów lub akcji wymaga zezwolenia ministra właściwego do spraw wewnętrznych, jeżeli w ich wyniku spółka będąca właścicielem lub użytkownikiem wieczystym nieruchomości na terytorium RP stanie się spółką kontrolowaną. Jeśli spółka handlowa z siedzibą na terytorium RP, będąca właścicielem lub użytkownikiem wieczystym nieruchomości na terytorium RP, jest spółką kontrolowaną, a udziały lub akcje nabywa lub obejmuje cudzoziemiec niebędący udziałowcem lub akcjonariuszem, to czynność taka również wymaga zezwolenia ministra właściwego do spraw wewnętrznych. Powyższa regulacja wynika $\mathrm{z}$ obowiązującej w prawie polskim zasady wymagającej zezwolenia ministra właściwego do spraw wewnętrznych na nabycie przez cudzoziemca prawa własności nieruchomości lub prawa użytkowania wieczystego, na podstawie każdego zdarzenia prawnego ${ }^{11}$. W rozumieniu ustawy o nabywaniu nieruchomości przez cudzoziemców, cudzoziemcem jest osoba fizyczna nieposiadająca obywatelstwa polskiego, osoba prawna mająca siedzibę

11 Ustawa z dnia 24 marca 1920 r. o nabywaniu nieruchomości przez cudzoziemców (t.j. Dz.U. 2017, poz. 2278). 
za granicą, nieposiadająca osobowości prawnej spółka w/w osób, mająca siedzibę za granicą, utworzona zgodnie z ustawodawstwem państw obcych oraz osoba prawna i spółka handlowa nieposiadająca osobowości prawnej mająca siedzibę na terytorium RP, kontrolowana bezpośrednio lub pośrednio przez osoby lub spółki wyżej wymienione. Ustawa o nabywaniu nieruchomości przez cudzoziemców zawiera szereg wyłączeń od obowiązku uzyskania zezwolenia, spośród których największe znaczenie posiada zwolnienie z wymogu uzyskania zezwolenia przez cudzoziemców będących obywatelami lub przedsiębiorcami państw - stron umowy o Europejskim Obszarze Gospodarczym albo Konfederacji Szwajcarskiej.

Przedsiębiorcy zagraniczni z państw członkowskich (a więc osoby zagraniczne wykonujące działalność gospodarczą w państwie członkowskim) mogą na terytorium RP tworzyć oddziały. Oddział tworzony jest wyłącznie dla wykonywania działalności gospodarczej na terytorium RP w zakresie, w jakim przedsiębiorca zagraniczny prowadzi tę działalność za granicą. Przedsiębiorcy zagraniczni z innych państw niż państwa członkowskie mogą tworzyć oddziały na zasadzie wzajemności, o ile ratyfikowane umowy międzynarodowe nie stanowią inaczej. Oddział przedsiębiorcy zagranicznego podlega rejestracji w Rejestrze Przedsiębiorców Krajowego Rejestru Sądowego.

Utrzymana została dotychczasowa zasada braku odrębnej podmiotowości prawnej oddziału przedsiębiorcy zagranicznego w świetle przepisów prawa polskiego. Oddział stanowi zatem wyodrębnioną i samodzielną organizacyjnie część działalności gospodarczej wykonywanej przez przedsiębiorcę zagranicznego i działa on w ramach podmiotowości prawnej samego przedsiębiorcy zagranicznego. $\mathrm{Z}$ tego powodu przepisy prawa wymagają, aby przedsiębiorca zagraniczny tworzący oddział na terytorium RP ustanowił osobę upoważnioną w oddziale do reprezentowania przedsiębiorcy zagranicznego. Zgodnie z art. 39 pkt 4 ustawy o Krajowym Rejestrze Sądowym ${ }^{12}$, osoba upoważniona przez przedsiębiorcę zagranicznego do reprezentowania go w oddziale musi być ujawniona w rejestrze przedsiębiorców.

Nowa regulacja ograniczyła obowiązek przeprowadzenia postępowania likwidacyjnego w trybie i na zasadach określonych w przepisach kodeksu spółek handlowych o likwidacji spółki z o.o. tylko do sytuacji, gdy likwidacja oddziału przedsiębiorcy zagranicznego następuje $\mathrm{w}$ wyniku wydania przez właściwego ministra decyzji o zakazie wykonywania działalności gospodarczej przez przedsiębiorcę zagranicznego w ramach oddziału. Określona w ustawie procedura wydania przez właściwego ministra decyzji o zakazie wykonywania działalności

12 Ustawa z dnia 20 sierpnia 1997 r. o Krajowym Rejestrze Sądowym (t.j. Dz.U. 2018, poz. 986 z późn. zm.). 
gospodarczej przez przedsiębiorcę zagranicznego w formie oddziału nie dotyczy przedsiębiorców zagranicznych państw członkowskich. W przypadku gdy przedsiębiorca zagraniczny samodzielnie podejmuje decyzję o likwidacji oddziału, wówczas - w przeciwieństwie do dotychczas obowiązujących regulacji - nie ma obowiązku przeprowadzenia postępowania likwidacyjnego $\mathrm{w}$ trybie i na zasadach określonych w kodeksie spółek handlowych o likwidacji spółki z o.o.

Przedsiębiorca zagraniczny może tworzyć na terytorium RP przedstawicielstwa, których zakres działania obejmuje wyłącznie prowadzenie działalności w zakresie reklamy i promocji przedsiębiorcy zagranicznego. Przedstawicielstwo nie może służyć do wykonywania działalności gospodarczej przez przedsiębiorcę zagranicznego na terytorium Polski. Utworzenie i prowadzenie przedstawicielstwa wymaga wpisu do rejestru przedstawicielstw przedsiębiorców zagranicznych. Co istotne, wpis do rejestru dokonywany jest na okres 2 lat od dnia dokonania wpisu, na wniosek przedsiębiorcy zagranicznego wpis zostaje wydłużony na kolejny okres 2 lat.

Na marginesie należy dodać, że ustawa o zasadach uczestnictwa przedsiębiorców zagranicznych i innych osób zagranicznych w obrocie gospodarczym na terytorium Rzeczypospolitej Polskiej, choć mająca wymiar regulacji kompleksowej i scalającej rozproszone dotychczas przepisy prawa, nie jest wyłącznym źródłem prawa określającym organizacyjnoprawne warunki działalności podmiotów zagranicznych w polskim obrocie gospodarczym. Poza jej zakresem znajdują się np. przepisy określające procedury transgranicznego łączenia się spółek kapitałowych i komandytowo-akcyjnych (regulowane przepisami kodeksu spółek handlowych ${ }^{13}$ ).

\subsection{Transgraniczna działalność usługowa}

Ustawa o zasadach uczestnictwa przedsiębiorców zagranicznych i innych osób zagranicznych w obrocie gospodarczym na terytorium RP inkorporuje przepisy określające warunki wykonywania transgranicznej działalności usługowej. Kluczową kwestią z punktu widzenia tej regulacji jest pojęcie „usługi”, definiowane w art. 3 pkt 8 ustawy jako świadczenie wykonywane przez usługodawcę z państwa członkowskiego na własny rachunek, zwykle za wynagrodzeniem, w szczególności usługi budowlane, handlowe oraz usługi świadczone w ramach wykonywanego zawodu. Pomijając fakt, że definicja ta obarczona jest błędem logicznym idem per idem (usługą są (...) usługi), jej brzmienie skłania do kilku spostrzeżeń. Przede wszystkim ustalenia wymaga jej zakres przedmio-

13 Ustawa z dnia 15 września 2000 r. - Kodeks spółek handlowych (t.j. Dz.U. 2017, poz. 1577 z późn. zm.). 
towy, a więc określenie do jakiego rodzaju aktywności gospodarczej odnoszą się analizowane przepisy ustawy. Definicja usługi, zawarta w ustawie, swoim brzmieniem nawiązuje do pojęcia „usługi” zawartego w art. 57 Traktatu o funkcjonowaniu Unii Europejskiej, zgodnie z którym usługami są świadczenia wykonywane zwykle za wynagrodzeniem w zakresie, w jakim nie są objęte postanowieniami o swobodnym przepływie towarów, kapitału i osób. Zgodnie z art. 57 TFUE, usługi obejmują zwłaszcza: działalność o charakterze przemysłowym, działalność o charakterze handlowym oraz wykonywanie wolnych zawodów. Zgodnie natomiast $\mathrm{z}$ art. 4 pkt 1 dyrektywy usługowej usługa oznacza wszelką działalność gospodarczą prowadzoną na własny rachunek, zwykle świadczoną za wynagrodzeniem, zgodnie z art. 50 Traktatu. Regulacje unijne dają więc podstawę dla szerokiego rozumienia pojęcia „usługi” jako działalności gospodarczej w szczególności o charakterze przemysłowym, handlowym oraz wykonywanie wolnych zawodów. Polski ustawodawca, formułując definicję usługi, również posługuje się jedynie przykładowym wyliczeniem rodzajów aktywności gospodarczych, klasyfikowanych do tej kategorii pojęciowej. Katalog ten nie ma więc charakteru zamkniętego, natomiast jego normatywne dekodowanie musi być przeprowadzane z uwzględnieniem licznych wyłączeń określonych w art. 12 ustawy (odnoszących się do szczególnych kategorii aktywności gospodarczych, do których przepisy ustawy nie mają zastosowania).

Usługodawca z państwa członkowskiego może czasowo świadczyć usługi na terytorium RP na zasadach określonych w przepisach TFUE albo w postanowieniach umów regulujących swobodę świadczenia usług, bez konieczności uzyskania wpisu do rejestru przedsiębiorców w Krajowym Rejestrze Sądowym albo Centralnej Ewidencji i Informacji o Działalności Gospodarczej. Usługodawcą jest przedsiębiorca zagraniczny z państwa członkowskiego, który wykonuje działalność gospodarczą zgodnie z obowiązującymi w tym państwie przepisami, a na terytorium RP czasowo oferuje lub świadczy usługę. Czasowe wykonywanie usługi może wiązać się z obowiązkiem uzyskania koncesji, zezwolenia, wpisu do rejestru działalności regulowanej, certyfikatu lub inną formą reglamentacji, o ile przepisy ustaw odrębnych nakładają taki obowiązek ze względu na porządek publiczny, bezpieczeństwo publiczne, bezpieczeństwo państwa, zdrowie publiczne lub ochronę środowiska naturalnego. Usługodawca z państwa członkowskiego może świadczyć usługi samodzielnie lub łącznie z innymi usługodawcami z państwa członkowskiego, a odstępstwo od tej zasady może nastąpić w odrębnych ustawach i jest dopuszczalne wyłącznie w celu określonym przez ustawę. Na usługodawcy ciążą obowiązki informacyjne wynikające z ustawy.

Osoby zagraniczne, inne niż przedsiębiorca z państwa członkowskiego, mogą świadczyć usługi na terytorium RP na zasadach określonych w wiążących Rzecz- 
pospolitą Polską umowach międzynarodowych lub - w braku takich umów - na zasadzie wzajemności.

\section{Podsumowanie}

Wprowadzone Konstytucją Biznesu zmiany normatywne w krajowym porządku prawnym w obszarze tworzącym organizacyjnoprawne warunki dla inwestycji zagranicznych na terytorium RP, poprzez przejrzystość i spójność regulacyjną, powinny przyczynić się do zmniejszenia barier wejścia kapitału zagranicznego na polski rynek. Polski ustawodawca wdraża w tym zakresie unijną dyrektywę usługową, a stworzone warunki prawne mają sprzyjać mobilności kapitału oraz intensyfikacji współpracy gospodarczej z przedsiębiorcami zagranicznymi. Przeprowadzona w ostatnim czasie gruntowna reforma polskiego prawa gospodarczego, dokonywana w celu poprawy sytuacji prawnogospodarczej przedsiębiorcy oraz ułatwienia relacji przedsiębiorca-państwo, powinna również wpłynąć na zwiększenie atrakcyjności rynku polskiego dla inwestorów zagranicznych.

\section{Bibliografia}

Begg, D., Vernasca, G., Fischer, S., Dornbusch, R. (2014). Makroekonomia. Warszawa: PWE. Budnikowski, A. (2017). Ekonomia międzynarodowa. Warszawa: PWE.

Burda, M. i Wyplosz, Ch. (2013). Makroekonomia. Podręcznik europejski. Warszawa: PWE. Dyrektywa 2006/123/WE Parlamentu Europejskiego i Rady z dnia 12 grudnia 2006 r. dotycząca usług na rynku wewnętrznym (Dz.Urz. UE L 276 z 27.12.2006).

Hejduk, I.K. i Bakalarczyk, S. (red.). (2013). Global Economics: Past, Present \& Future. Warszawa: Difin.

Kotyński, J. (red.). (2005). Globalizacja i integracja europejska: szanse i zagrożenia dla polskiej gospodarki. Warszawa: PWE.

Mankiw, N.G. i Taylor, M. (2016). Makroekonomia. Warszawa: PWE.

Nowak, A.Z. (2015). W: A.Z. Nowak, T. Zalega (red.), Makroekonomia. Warszawa: PWE.

Nowak, A.Z. (2017). Globalizacja jako makroekonomiczny megatrend. W: A.Z. Nowak, K. Ryć (red.), Polityka $w$ regionach $w$ warunkach globalizacji. Warszawa: Wydawnictwo Naukowe Wydziału Zarządzania UW.

Nowak, A.Z. (2017). Kryzysy a finansyzacja gospodarki światowej. W: A.Z. Nowak, K. Ryć (red.), Polityka $w$ regionach $w$ warunkach globalizacji. Warszawa: Wydawnictwo Naukowe Wydziału Zarządzania UW.

Orłowska, R. i Żołądkiewicz, K. (2012). Globalizacja i regionalizacja w gospodarce światowej. Warszawa: PWE. 
Ustawa z dnia 15 września 2000 r. - Kodeks spółek handlowych (t.j. Dz.U. 2017, poz. 1577 z późn. zm.).

Ustawa z dnia 2 lipca 2004 r. o swobodzie działalności gospodarczej (t.j. Dz.U. 2017, poz. $2168 \mathrm{z}$ późn. zm.).

Ustawa z dnia 20 sierpnia 1997 r. o Krajowym Rejestrze Sądowym (t.j. Dz.U. 2018, poz. 986 z późn. zm.).

Ustawa z dnia 24 marca 1920 r. o nabywaniu nieruchomości przez cudzoziemców (t.j. Dz.U. 2017, poz. 2278).

Ustawa z dnia 4 marca 2010 r. o świadczeniu usług na terytorium Rzeczypospolitej Polskiej (t.j. Dz.U. 2016, poz. 893 z późn. zm.).

Ustawa z dnia 6 lipca 1982 r. o zasadach prowadzenia na terytorium Polskiej Rzeczypospolitej Ludowej działalności gospodarczej w zakresie drobnej wytwórczości przez zagraniczne osoby prawne i fizyczne (t.j. Dz.U. z 1989 r., poz. 27 z późn. zm.).

Ustawa z dnia 6 marca 2018 r. - Prawo przedsiębiorców (Dz.U. 2018, poz. 646).

Ustawa z dnia 6 marca 2018 r. - Przepisy wprowadzające ustawę - Prawo przedsiębiorców oraz inne ustawy dotyczące działalności gospodarczej (Dz.U. 2018, poz. 650).

Ustawa z dnia 6 marca 2018 r. o Centralnej Ewidencji i Informacji o Działalności Gospodarczej i Punkcie Informacji dla Przedsiębiorcy (Dz.U. 2018, poz. 647 z późn. zm.).

Ustawa z dnia 6 marca 2018 r. o Rzeczniku Małych i Średnich Przedsiębiorców (Dz.U. 2018, poz. 648).

Ustawa z dnia 6 marca 2018 r. o zasadach uczestnictwa przedsiębiorców zagranicznych i innych osób zagranicznych w obrocie gospodarczym na terytorium Rzeczypospolitej Polskiej (Dz.U. 2018, poz. 649 z późn. zm.). 


\title{
Czy można zamienić państwa w huby motoryzacyjnej innowacji?
}

\begin{abstract}
Artykuł rozważa hipotezę, iż w obliczu nałożenia się czterech trendów, które będą kształtowały przyszłość przemysłu samochodowego: autonomizacji, urbanizacji, cyfryzacji i elektryfikacji, osiągnięcie sukcesu w przemyśle samochodowym w nadchodzących latach będzie wymagało synergicznej kooperacji pomiędzy sektorem prywatnym i publicznym. W kontekście globalnej konkurencji, której podmiotami są nie tylko pojedyncze przedsiębiorstwa, lecz także całe ekosystemy, państwa będą musiały na nowo przemyśleć swoją zdolność do dostarczania wartości dodanej dla swoich gospodarek. Na przykładzie elektromobilności artykuł proponuje pięć czynników sukcesu dla jej rozwoju w zależności od sytuacji państwa, są to: siła tradycyjnych firm samochodowych, oczekiwania społeczne, potencjał kreacji miejsc pracy, możliwości umiędzynarodowienia i zdolność do inkubacji nowych podmiotów. Ze wstępnej analizy, wymagającej dalszej rozbudowy i weryfikacji, wynika, iż państwa, takie jak Chiny, na starcie wydają się znajdować w uprzywilejowanej pozycji, aby najbardziej skorzystać z potencjału nowej mobilności.
\end{abstract}

Słowa kluczowe: elektromobilność, urbanizacja, autonomizacja, cyberbezpieczeństwo, rola państwa.

\section{Wprowadzenie}

Centralnym celem Nowej Ekonomii Strukturalnej jest przemyślenie na nowo państwa jako koła zamachowego rozwoju. Funkcjonujący od połowy dwudziestego wieku na Zachodzie paradygmat liberalny, którego częścią jest światowy handel, stopniowo przyjmowany przez kraje rozwijające się, a następnie wzmocniony upadkiem komunizmu, doprowadził do podniesienia poziomu życia na całej planecie. Jeżeli wziąć pod uwagę PKB per capita, statystyczny mieszkaniec planety wzbogacił się aż czterokrotnie pomiędzy $1980 \mathrm{r}$. a chwilą obecną, a proporcja najuboższych spadła z 42\% w $1993 \mathrm{r}$. do nawet poniżej $10 \%$ obecnie (Roser, 2018).

Efektem ubocznym globalnego rynku okazały się jednak potężne globalne nierówności. Pogłębiona kryzysem finansowym 2007-2008 r. oraz kryzysem 
strefy euro od 2009 r., rosnąca przepaść pomiędzy garstką coraz bogatszych, najbogatszych i wszystkimi pozostałymi poddała w wątpliwość zasadność globalizacji. Nierówności stały się przedmiotem kontestacji ze strony ekonomistów (Pikketty, 2010). Przełożyły się one również na rosnące zapotrzebowanie wyborców na politykę tożsamości (Fukuyama, 2018).

W efekcie państwa powracają na scenę, choć bardziej trafne byłoby stwierdzenie, że tak naprawdę nigdy z niej nie zeszły, a zwłaszcza te najbardziej skuteczne i rozwijające się. Ale powracająca refleksja nad potrzebą polityki przemysłowej, dawno niewidziane wojny celne, a nawet coraz częstsze korzystanie z polityki sankcji, są w świecie krajów rozwiniętych pewnym novum. Po latach konsumowania owoców wzrostu poprzez politykę społeczną, czerpania recepty na wzrost z konsensusu waszyngtońskiego, wzmacniania więzów regionalnych i budowania reguł globalnych, wszystkie państwa zostały zmuszone na nowo przemyśleć swoją rolę. W szczególności, w jaki sposób stać się wartością dodaną dla swoich gospodarek.

Hipotezą przyjętą w tym artykule jest twierdzenie, że państwa nie mogą tego robić skutecznie, abstrahując od globalnych trendów, które kształtują technologię, biznes, społeczeństwo i nasze otoczenie. Jednym z najciekawszych pól kumulacji tych trendów i nadchodzącej konfrontacji będzie przemysł motoryzacyjny, w którym kluczową rolę odegrają cztery siły: autonomizacja, urbanizacja, cyfryzacja oraz elektryfikacja. Ani firmy, ani pojedyncze państwa nie zdołają wydobyć pełnego potencjału z ich interakcji. Dzięki temu, że synergiczna kooperacja państwa i firm pozostanie bardziej wyjątkiem niż regułą, nagrodą za jej osiągnięcie będzie globalne przywództwo i renta gospodarcza w jednej z najbardziej lukratywnych gałęzi gospodarki na świecie.

\section{Transport autonomiczny}

Początek dwudziestego pierwszego wieku to okres bezprecedensowego przyśpieszenia innowacji. Opisując tę sytuację, szereg autorów oczekuje pojawienia się „punktu technologicznej osobliwości” (Kurzweil, 2005), w którym inteligencja maszyny wyprzedzi możliwości człowieka i w konsekwencji dojdzie do stopniowej fuzji człowieka i maszyny (Harari, 2018).

Dla przemysłu motoryzacyjnego ten moment nie kojarzy się jednak z fuzją, a wręcz z czymś dokładnie odwrotnym. Człowiek nie będzie musiał kierować samochodem, ponieważ maszyna będzie wystarczająco inteligentna, żeby wykonać tę pracę za niego. Będący owocem technologii cyfrowej i wyrosłych 
z niej sztucznej inteligencji i automatyzacji, transport autonomiczny pobudza wyobraźnię i mobilizuje czołowe zespoły badawcze i zasoby. Większość dużych producentów samochodów przewiduje, że w pierwszej połowie lat 2020 nastąpi przełom i na drogach pojawią się pierwsze pojazdy w pełni autonomiczne. Najpierw będą to pojazdy luksusowe bądź dostawcze poruszające się po przewidywalnych i długich trasach - długodystansowe. Mało kto jednak wątpi, że w perspektywie $2030 \mathrm{r}$. pojazdy autonomiczne w jakiejś formie będą obecne również w miastach.

Wyzwania technologiczne przestają być jedynie obszarem zarezerwowanym dla firm technologicznych. Tworzą się sojusze pomiędzy tradycyjnymi graczami motoryzacyjnymi i nowymi - technologicznymi, jak np. BMW i Intel, FiatChrysler i Google (Waymo) albo Renault-Nissan i Google. Jak podaje bank Morgan Stanley, pomiędzy 2013 i 2016 r. nastąpił dziesięciokrotny wzrosły zakupów firm technologicznych przez firmy nietechnologiczne (Morgan Stanley, 2018). W charakterze kupujących i hubów innowacji cyfrowej firmy, takie jak Ford, GM czy Uber, dołączyły do tradycyjnych gigantów technologicznych, jak Apple, Google, Facebook czy IBM. Pośród różnych obszarów technologii najszybciej rosnącym segmentem wzrostu stała się sztuczna inteligencja. Jedna z jej głównych aplikacji - rozpoznawanie otoczenia niezbędne dla upowszechnienia samochodów autonomicznych, czyli machine vision - przyniosła w ciągu ostatnich 24 miesięcy jedną trzecią transakcji M\&A w tym obszarze. Najbardziej spektakularną pozostał zakup przez amerykański Intel w 2017 roku izraelskiego start-upu Mobileye produkującego system wizualizacji dla wsparcia kierowcy w prowadzeniu pojazdu. Niedawno zaś, symptomatyczne było przejęcie przez chińskiego giganta technologicznego, Baidu, amerykańskiego start-upu xPerceptions. Dowiódł on bowiem, że wyścig do samochodu autonomicznego przestał być domeną jedynie tradycyjnego świata zachodniego (Hampleton, 2018).

Można się więc spodziewać, że w perspektywie nadchodzących kilkunastu lat pojawiają się pierwsze w pełni autonomiczne pojazdy, które stopniowo upowszechniać się będą w coraz bardziej złożonym środowisku komunikacyjnym, na końcu w miastach. Autonomiczna rewolucja odciąży człowieka z prowadzenia pojazdu, dając tym samym więcej czasu na inne aktywności. Jednocześnie jednak będzie skłaniać do dłuższych podróży, a co za tym idzie do dalszego zwiększania się odległości pomiędzy domem i miejscem pracy. Pod warunkiem nadążenia rozwoju infrastruktury za nowymi możliwościami pojazdu, przełoży się to na dalszy, spektakularny rozwój miast. 


\section{Urbanizacja}

O ile na początku dziewiętnastego wieku jedynie jeden na 50 mieszkańców ziemi mieszkał w mieście, o tyle obecnie aż połowa ludności świata zamieszkuje obszary miejskie. Największe miasta świata w ciągu ostatnich zaledwie kilkudziesięciu lat przeszły spektakularny wzrost. W 1990 r. było 10 megamiast liczących każde ponad $10 \mathrm{mln}$ mieszkańców. Obecnie jest ich już prawie 30 i są zamieszkałe przez niewiele mniej niż 500 milionów ludzi. W perspektywie 2050 roku na całym świecie dwóch na trzech mieszkańców będzie mieszkało w miastach. Oznacza to pomiędzy 6 a 7 miliardów ludzi spośród 9 miliardów zamieszkujących całą planetę (...).

Urbanizacja pociąga za sobą szereg konsekwencji, których skali ani siły oddziaływania nie do końca jesteśmy sobie w stanie wyobrazić. Jedną z najważniejszych będzie odpowiedź na zapotrzebowanie mobilności: z miast „w świat” - jako turyści; pomiędzy miejscem pracy i miejscem zamieszkania - jako pracownicy; pomiędzy miastami - w interesach. Wzrośnie zapotrzebowanie na indywidualizację poruszania się, choć niekoniecznie na własność środków transportu. Wygoda mierzona dostępem i łatwością użytkowania, a nie społeczna aspiracja mierzona posiadaniem, będzie nową normą. Już dzisiaj Nowy Jork posiada znacznie mniejsze nasycenie samochodami niż Warszawa. Samochód, jako narzędzie samorealizacji będzie tracił na znaczeniu wobec pojazdu pozwalającego płynnie przemieszczać się z miejsca A do miejsca B. Sukces Ubera czy Lyfta są już tego przedsmakiem. Firmy samochodowe coraz bardziej zdają sobie $\mathrm{z}$ tego sprawę, a wymowne w tym kontekście są globalne sojusze budowane przez przewoźników miejskich i producentów pojazdów: GM i Lyft, Volvo i Uber.

Banalizacja pojazdu jest nieuchronna, jeśli zdamy sobie sprawę ze skali nadchodzącego wyzwania. Zaopatrzenie w środki transportu, zwłaszcza samochody, jest bardzo nierówne pomiędzy różnymi częściami świata. W Europie na 1000 mieszkańców przypada między 300 a 600 samochodów. W Stanach Zjednoczonych jest to już prawie stosunek jeden do jednego. W Indiach ten stosunek w dalszym ciągu wynosi jedynie 50 samochodów na 1000 mieszkańców. Przy czym trzeba mieć na uwadze, że Indie to kraj szybko rozwijający się, kraj ludzi młodych: w 2030 r. 60\% hindusów będzie miało poniżej trzydziestego roku życia; a w 2050 r. 700 mln ludzi będzie tam mieszkało w miastach. Czy możemy sobie zatem wyobrazić jeszcze więcej samochodów poruszających się po drogach tego kraju? Sadząc po zatłoczonych ulicach New Delhi, Kalkuty, Mumbaju $\mathrm{i}$ innych wielkich miast wydaje się to prawie niemożliwe. Zaspokojenie potrzeb i aspiracji mieszkańców miast, np. w Indiach czy w Chinach, w zakresie mobilności stanie się jednym z największych wyzwań XXI wieku. 
W kontekście urbanizacji nie jest jasne czy upowszechnienie pojazdów autonomicznych przyczyni się do rozładowania problemów komunikacyjnych, czy też wręcz przeciwnie - doprowadzi do ich pogłębienia. $Z$ jednej strony, poprzez współdzielenie, pojazd autonomiczny uwolni niezagospodarowany dzisiaj czas korzystania z pojazdów, zwalniając jednocześnie miejsca parkingowe. $\mathrm{Z}$ drugiej zaś - człowiek będzie mógł inaczej zagospodarować czas podczas jazdy, przeznaczając go na rozrywkę, pracę i odpoczynek. Wygoda nieposiadania środka transportu połączona z taniością korzystania z niego może powodować wypieranie transportu publicznego, co jest już częściowo obserwowane w miastach, gdzie upowszechnił się np. Uber.

W efekcie istnieje ryzyko, że miasto jeszcze bardziej się rozciągnie w przestrzeni i ulegnie jeszcze większemu zatłoczeniu w centrach. Wstępne badania opracowane na podstawie doświadczeń z transportem autonomicznym w Bostonie wydają się potwierdzać tę tezę (BCG, 2018). Jakkolwiek w wyniku hipotetycznego upowszechnienia transportu autonomicznego całkowity czas podróży skróci się, jednak w centrum ulegnie on wydłużeniu („efekt zatłoczenia”), podczas gdy w suburbiach w znaczący sposób skróci dojazdy (w konsekwencji prowokując zapewne „efekt rozciągnięcia”). Te badania prowadzone są jednak ceteris paribus, bez zmiany innych parametrów, jak np. polityka w zakresie transportu publicznego, opodatkowanie i ograniczenie wjazdów do centrów miast, dostępność miejsc parkingowych. A jak pokazuje przykład Tokio, możliwe jest bardzo radykalne odciążenie centrum miasta od ruchu samochodowego, dzięki bardzo dobremu dostępowi do transportu publicznego. $\mathrm{Z}$ podobnych przesłanek wychodzą władze Singapuru, które zakładają, że do 2030 roku $80 \%$ mieszkańców miasta będzie miało stację metra lub autobusu w promieniu 5 minut piechotą od miejsca swojego zamieszkania. Najlepiej skonfigurowane systemy miejskie będą zniechęcały do posiadania pojazdu indywidualnego.

W każdym przypadku, interakcja pomiędzy urbanizacją i autonomizacją będzie stanowić wyzwanie. Poprzez autonomizację nastąpi ograniczenie kosztu transportu indywidualnego, co nieuchronnie przełoży się na zwiększony popyt na takie usługi. W efekcie rolę hamulca wezmą na siebie włodarze miast i regulatorzy. Poprzez ograniczenia ruchu, wspieranie transportu publicznego, rozbudowę infrastruktury będą ograniczać pojazdy indywidualne w centrach. Ich sojusznikiem będzie cyfrowa integracja pojazdów i infrastruktury. 


\section{Pojazdy zintegrowane cyfrowo}

Jednym z najbardziej oczywistych megatrendów ostatnich lat, o których dużo się już mówi, jest rosnące znacznie komunikacji i wymiany danych pomiędzy urządzeniami. W szczególności pojazdy integrują się cyfrowo z innymi pojazdami i infrastrukturą. W 2020 roku wszystkie nowe pojazdy będą połączone w sieci (BCG, 2018). To szansa na zwiększenie bezpieczeństwa ruchu, ograniczenie awaryjności. Połączone w sieci pojazdy autonomiczne ograniczą rolę najsłabszego ogniwa w prowadzeniu pojazdu, jakim jest człowiek. Będą mniej narażone na wypadki. Komunikacja z zapleczem serwisowym pozwoli szybciej i lepiej reagować na awarie i problemy techniczne. Ale nie tylko.

Pojazdy zintegrowane cyfrowo i komunikujące się między sobą otworzą nowe perspektywy przed ubezpieczycielami, reklamodawcami, różnymi usługodawcami. Odciążony od uwagi niezbędnej dzisiaj do prowadzenia pojazdu pasażer stanie się atrakcyjnym obiektem działań reklamowych. Możliwość dostarczania produktów do poruszających się pojazdów pozwoli zintegrować drony i pojazdy. Wokół mobilności pojawią się nowe modele biznesowe i nowe przemysły.

Stopniowa digitalizacja wszystkich obszarów aktywności ludzkiej otwiera ogromny potencjał. W kontekście pojazdów autonomicznych i połączonej infrastruktury stawia jednocześnie wyzwanie związane z zapewnieniem bezpieczeństwa danych. Wypadki w przyszłości będą zapewne mniej liczne, ale te które będą miały miejsce mogą być bardziej spektakularne, jeżeli ich powodem będzie działalność terrorystyczna bądź awaria systemu. Cyberbezpieczeństwo stanie się jedną z najbardziej kluczowych dziedzin gospodarki. Potrzeba jej zapewnienia będzie również motywowała do rosnącej interwencji państw. Nie będzie możliwe utrzymanie całościowej ciągłości działania systemu bez jego scentralizowanego monitoringu. O ile wykreowanie standardów bezpieczeństwa będzie udziałem sektora prywatnego, o tyle ich upowszechnienie będzie rolą regulatora.

Cyfryzacja będzie postępowała ramię w ramię z rosnącym znaczeniem energii elektrycznej. O ile mówi się, że XX wiek stał pod znakiem ropy naftowej, o tyle coraz więcej wskazuje na to, że XXI będzie wiekiem elektryfikacji. Energia elektryczna jako napęd rozwoju cywilizacji to również nowa perspektywa dla sektora transportu drogowego. 


\section{Elektryfikacja jako odpowiedź na zanieczyszczenie środowiska i wyzwania klimatyczne}

Szybki rozwój gospodarczy końca XX wieku to również rosnące wyzwanie klimatyczne i środowiskowe. Z perspektywy zobowiązań podjętych przez państwa w ramach porozumienia paryskiego niezbędne stało się ograniczenie emisji dwutlenku węgla w transporcie. Stał się on najszybciej rosnącym źródłem emisji w krajach OECD (IEA, 2018). W szybko rozwijających się krajach Południa miasta stały się siedliskiem smogu i głównym źródłem hałasu. Na całym świecie w niespotykanym tempie pogarsza się jakość powietrza spowodowana właśnie rosnącym ruchem samochodowym. Pociaga on za sobą emisje cząstek sadzy i tlenków azotu. Ponad trzy miliony przedwczesnych zgonów na świecie jest związanych z zanieczyszczeniem powietrza cząstkami sadzy 2,5 PM. Jedna na cztery z tych cząsteczek pochodzi z transportu (CCAC, 2018).

Samochody elektryczne to odpowiedź na rosnące zapotrzebowanie na czystsze miasta bez hałasu. Zastąpienie samochodu spalinowego samochodem elektrycznym zmniejsza emisje tlenków azotu nawet o $80 \%$. Samochody elektryczne pozwalają na zmniejszenie smogu w miastach. Pozwalają na redukcję emisji dwutlenku węgla od 25 do nawet $60 \%$ w zależności od sposobu produkcji energii elektrycznej. Upowszechnienie samochodów elektrycznych w miastach obniży poziom hałasu na ulicach. Dodatkowo samochód elektryczny może być bardzo wygodny. Jak pokazują badania na rynkach, gdzie doszło do ich upowszechnienia - np. w Norwegii czy w Kalifornii - kierowcy chętnie ładują swój samochód w domu, bez konieczności korzystania ze stacji paliw (IEA, 2018). W wielu krajach ładowanie w nocy dodatkowo obniża koszt użytkowania samochodu. Nie ma manualnej skrzyni biegów, co jest szczególnie wygodne podczas jazdy w mieście.

Do niedawna, jeszcze do pierwszych lat XXI wieku, pojazdy elektryczne nie miały szans na upowszechnienie ze względu na: zaporowy koszt baterii, brak infrastruktury ładowania, niechęć tradycyjnych producentów samochodowych do kanibalizowania swojego know-how, brak rynku wtórnego. Wiele jednak wskazuje, że to właśnie one wkrótce staną się konkurencyjne kosztowo dla tradycyjnych pojazdów spalinowych. Spośród paliw alternatywnych to elektromobilność upowszechni się najszybciej. Pozostawi ona w tyle pojazdy wodorowe, jak również napędzane biopaliwami i gazem, choć oczywiście nie można wykluczyć, że kolejne innowacje przełamią z czasem i ten trend.

Stanie się tak dlatego, że koszt posiadania samochodu to nie tylko koszt zakupu, lecz także koszt paliwa, napraw i serwisu. Już obecnie poruszanie się 
samochodami elektrycznymi jest tańsze i wygodniejsze niż autami spalinowymi. Mniejsze są koszty napraw i serwisu, bo samochody elektryczne są mniej złożone (silnik i skrzynia biegów to około 1000 części mniej), nie potrzebują wymiany oleju ani filtrów. Jednak kluczem do ich upowszechnienia stanie się spadający koszt baterii litowo-jonowych, który przełoży się na niższą cenę zakupu samochodu elektrycznego. Stanowiące $40 \%$ kosztu jego wyprodukowania baterie tanieją o 10-15\% rocznie (IEA, 2018). W efekcie, ocenia się, że w perspektywie 2020-2022 całkowity koszt posiadania samochodu elektrycznego - liczony łącznie jako koszt zakupu i użytkowania w okresie co najmniej pięcioletnim - będzie niższy od samochodu spalinowego. Rynek będzie rozwijał się coraz szybciej, przechodząc ze wzrostu liniowego w wykładniczy, co już jest zauważalne: aby sprzedać pierwszy milion samochodów elektrycznych potrzeba było 60 miesięcy, drugi milion zabrał tylko 17 miesięcy, trzeci to już 10 miesięcy, a czwarty milion został osiągnięty w sierpniu 2018 roku w 6 miesięcy. W pespektywie globalnej ocenia się, że z obecnego $1 \%$ pojazdów, „elektryki” osiągną pomiędzy 20 a $40 \%$ udziału w rynkach. W samej Europie w 2030 roku będzie to $5 \mathrm{mln}$ nowych samochodów elektrycznych rocznie. W perspektywie 2040 roku pomiędzy 250 a 500 milionów pojazdów, spośród 2 miliardów na świecie, będzie napędzanych energią elektryczną.

\section{Rozwój przemysłu motoryzacyjnego a rola państwa}

Środki transportu, przede wszystkim zaś samochód indywidualny, będą zatem przez najbliższe dziesięciolecia podlegały intensywnej (r)ewolucji. Rosnąca urbanizacja połączona $\mathrm{z}$ digitalizacją $\mathrm{i}$ autonomizacją wymusi nowe modele biznesowe i regulacyjne. Następować będzie wypieranie samochodu ze sfery własności do sfery korzystania. Postęp technologiczny umożliwi ewolucję napędu od silnika spalinowego do elektrycznego.

Z pojazdów przyszłości będziemy korzystać na inne sposoby niż dotychczas, ewoluując od własności do współdzielenia. Ocenia się, że w 2025 roku będzie 80 milionów użytkowników car-sharingu na świecie. W perspektywie $2030 \mathrm{r}$. jedna trzecia podróży w Indiach będzie odbywanych za pomocą współdzielonych środków transportu, co postawi ten kraj w roli lidera tego typu komunikacji. Współdzielenie zakorzeni się jako alternatywa dla rozbudowania transportu publicznego, który wśród krajów rozwijających nie cieszy się należną mu popularnością, wymagając długookresowego planowania przestrzennego i środków na inwestycje. 
Elektryczne, ładowane w nocy pojazdy przyszłości będą poruszały się w sposób zautonomizowany po ustalonych trasach. Upowszechnią się zróżnicowane pojazdy dostawcze, od ciężarowych, poprzez półciężarowe, po transport ostatniej mili, być może łącznie z dronami. Podobnie jak pierwsze samochody wyglądem przypominały dorożki, podobnie pojazd przyszłości nie musi przypominać swojego dziadka z XIX ani ojca z XX wieku. Pomiędzy pojazdem rodzinnym a autobusem otworzy się przestrzeń na małe, autonomiczne pojazdy dowożące na krótkie odległości: pomiędzy miejscem zamieszkania i metrem; w obrębie dzielnicy. To szansa dla nowych firm, które skoncentrują się tylko na samochodach elektrycznych. W szczególności powstanie niskobudżetowego samochodu elektrycznego radykalnie zmieni obraz rynku.

Samochody elektryczne ograniczą zależność od ropy. Wiele państw uzna ten argument za wystarczająco atrakcyjny, aby wesprzeć upowszechnienie pojazdów elektrycznych.

Państwo będzie odgrywało kluczową rolę w dostępie do nowego potencjału wartości. Nie będzie autonomicznego transportu bez wyrafinowanych regulacji prawnych, definiujących odpowiedzialność stron i standardy bezpieczeństwa. Współdzielenie transportu zyska znacznie na przywilejach, w tym fiskalnych. Elektryfikacja nie będzie możliwa bez determinacji legislatorów i początkowego dofinansowania ze środków publicznych. Cyfrowa mobilność będzie uwarunkowana dostępem do wyrafinowanych kompetencji cyberbezpieczeństwa, które jako dobro publiczne będzie w stanie zgromadzić jedynie wspólnota na poziomie państwa. Nie będzie nowych, wysoko płatnych miejsc pracy bez zaawansowanych systemów edukacyjnych.

Otworzą się nowe modele biznesowe, stare zostaną doprowadzone do ruiny, dając szansę nowym graczom lub ugruntowując przewagę istniejących. Nowa mobilność, cyfrowa, autonomiczna, elektryczna i współdzielona to perspektywa na rozwój dla przemysłu motoryzacyjnego. Szacuje się, że w ciągu nadchodzących 20 lat przybędzie 2500 miliardów dolarów nowych przychodów. W tym samym czasie dotychczasowe technologie praktycznie nie drgną. Cały, $40 \%$ wzrost sektora przypadnie na nową mobilność, otwierając „błękitny ocean” (...) dla pionierów. W tradycyjnym biznesie samochodowym brak dynamiki wzrostu będzie oznaczać regres (BCG, 2018). Więcej prostej konkurencji, siłą rzeczy kosztowej, kontynuacja raczej niż przełom ugruntują „,czerwony ocean” jako przestrzeń konkurencji dla tradycyjnego przemysłu samochodowego.

Najlepsi pionierzy zbiorą rentę pierwszeństwa. Państwa, które w sposób synergiczny przekształcą swój przemysł w kierunku nowej mobilności zyskają szansę na światowe przywództwo. Firmy, które skorzystają na wyobraźni swoich zarządzających i legislatorów wykorzystają potencjał rodzimych rynków i aktywów dla 
zbudowania globalnej przewagi. Nowa mobilność przewartościuje dotychczasowy pejzaż konkurencyjny. Jakkolwiek tradycyjni producenci samochodowi pozostaną dobrze spozycjonowani, aby wychwycić potencjał nowej wartości, to nie jest im on dany automatycznie. Elektryfikacja pojazdu postawi wszystkich na nowej linii startu. Nowe modele biznesowe otworzą nowe przestrzenie konkurencji. Nowi producenci, m.in. tacy jak Tesla, NIO, Faraday Future, Lucid mają w tym nowym wyścigu unikalną szansę na równorzędny start razem z BMW, Renault i Fordem. Może również okazać się, że elektromobilni innowatorzy - poprzez unikalną szansę na brak nagromadzonego bagażu zaszłości tradycyjnych producentów - zyskają nawet na starcie przewagę w tym nowym, globalnym rozdaniu. W końcu przekraczająca kapitalizację GM wycena Tesli też o czymś świadczy.

\section{Szanse dla nowych producentów}

Połączenie biznesowej, społecznej i technologicznej zmiany to niepowtarzalny moment dla nowych producentów. Dominacja silnika spalinowego utrwaliła na przestrzeni XX wieku określoną strukturę rynku. Jednak producenci klasyczni nie mają interesu w szybkiej elektryfikacji transportu. $Z$ jednej strony potrzebują czasu na zamortyzowanie inwestycji w auta spalinowe. $Z$ drugiej - utraca nawet do 50\% marży pochodzącej obecnie z serwisu. To właśnie poprzez części zamienne uzyskują swoją rentowność w całym cyklu życia pojazdu. W sytuacji, kiedy pojazd elektryczny jest znacząco prostszy, nie będą w stanie wykorzystywać swoich aktywów produkcyjnych ani dostawców.

Ocenia się, iż w samej tylko grupie Volkswagen elektryfikacja pojazdów spowoduje ograniczenie zatrudnienia o co najmniej 10\%, czyli 60 tys. pracowników. Broniąc się, klasyczni producenci stosują wszelkie dostępne, a nawet nielegalne metody, aby ograniczyć tempo tej transformacji. Namacalnym tego dowodem może stać się postępowanie o zmowę uruchomione we wrześniu 2018 roku przez Komisję Europejską o ograniczenie upowszechniania czystego transportu przez europejskich producentów. Prowadzą więc oni elektryfikację w sposób selektywny, koncentrując się na segmentach niemasowych. W mniejszym stopniu starają się o zdominowanie nowych obszarów, w większym zaś - walczą o utrzymanie dotychczasowych.

Dodatkowym wyzwaniem jest dla nich bagaż nieefektywności, który za sobą niosą historycznie. Rozbudowane sieci dilerskie okazują się w dobie Internetu nieefektywne i kosztowne, czego ilustracją jest sposób sprzedaży bezpośredniej, jaki stosuje Tesla. Struktura zatrudnienia w fabrykach jest niedostosowana do 
samochodów elektrycznych ze względu nie tylko na skalę, lecz także na kompetencje. Umiejętności w zakresie energochemii, elektryki, informatyki niezbędne dla produkcji bateryjnych „komputerów na kółkach” zastępują klasyczne umiejętności w zakresie mechaniki i silników.

Nowa mobilność pozwoli na stworzenie wysoko płatnych miejsc pracy. Każda nowa fabryka samochodów elektrycznych bądź złożonych komponentów oznacza setki, a często tysiące nowych miejsc pracy. Każde miejsce pracy u producenta samochodów pozwala na utworzenie dodatkowych 3-5 miejsc pracy poza fabryką, np. u poddostawców. Nie tylko wysokie wynagrodzenia, lecz także kompetencje w zakresie automatyzacji, sztucznej inteligencji czy cyberbezpieczeństwa przyniosą dodatkowe korzyści w innych obszarach: inteligentnego miasta, energetyki, bezpieczeństwa, IT bankowości, ubezpieczeniach. Firmy nowej mobilności przyczynią się do promocji wizerunku swojego państwa.

Uruchomienie rentownej produkcji na poziomie kilkuset tysięcy egzemplarzy to inwestycja rzędu kilku do kilkunastu miliardów dolarów, która jakkolwiek ryzykowna, może już być atrakcyjna dla kapitałodawców, a na pewno dla państw i regionów, które na nie postawią. Wymownym przykładem tego jest wspierane publicznymi środkami, ale również ogromną kapitalizacją powstanie Tesli, w ślad za którą idą obecnie kolejni.

\section{Elektryfikacja transportu i strategie wybranych państw}

Nie wszystkie państwa i nie każdy ekosystem gospodarczy będzie jednak w stanie skorzystać z opisanej (r)ewolucji. Większość państw ugrzęźnie w nieefektywnościach charakteryzujących biurokrację lub w ociężałościach systemu politycznego. Mało jest miejsc na świecie, gdzie możliwe jest zgromadzenie wystarczającego kapitału do inkubacji nowych, ryzykownych biznesów. Na wielu dojrzałych rynkach zmiana technologiczna napotka opór współczesnych „luddystów", dla których będzie ona niosła za sobą utratę dotychczasowego zajęcia. Nawet jeśli lokalnie wykiełkują nowe podmioty, a system regulacyjny okaże się wystarczająco sprawny, aby je wesprzeć, w rysującym się na horyzoncie świecie gospodarczej fragmentaryzacji nie jest pewne czy uda się je wyprowadzić na rynki globalne, dając szanse na rozwinięcie skrzydeł. Zaistnieje wiele przeszkód, które zahamują uruchomienie synergicznej kooperacji pomiędzy państwem i firmami, znajdującymi się w jego obszarze wpływów.

Ujęcie wszystkich możliwych współzależności pomiędzy wymienionymi czterema trendami i strategiami państw jest wzywaniem wykraczającym poza poje- 
dynczy artykuł. Chcąc jednak zbudować pewien zespół hipotez - czynników sukcesu synergicznej kooperacji - opisana poczwórna rewolucja została zredukowana tylko do zmiany technologicznej, czyli przejścia z pojazdu spalinowego do elektrycznego.

Dla uzyskania pełnego potencjału rozwoju wynikającego z elektryfikacji napędów pojazdów zakłada się zatem, iż skuteczna interakcja pomiędzy sektorem publicznym i prywatnym będzie zależna od kombinacji co najmniej pięciu czynników: siły tradycyjnych firm samochodowych, odpowiedzi na oczekiwania społeczne, potencjału tworzenia nowych miejsc pracy, możliwości umiędzynarodowienia oraz zdolności do inkubacji nowych graczy. Każdy z nich został poniżej zarysowany na przykładzie siedmiu państw: Niemiec, Chin, USA, Francji, Wielkiej Brytanii, Norwegii i Polski. Wybór krajów jest arbitralny, a opis sytuacji w każdym z nich nie pretenduje do zupełności, a jedynie służy postawieniu pewnych hipotez, które będą mogły stanowić podstawę do dalszych badań.

Największym wyzwaniem na drodze do skorzystania z potencjału elektrycznej mobilności jest siła tradycyjnych firm samochodowych. Ponieważ skuteczna zmiana technologiczna wymaga płynnej i synergicznej kooperacji pomiędzy państwem i sektorem prywatnym, więc państwa, w których funkcjonuje tradycyjny przemysł motoryzacyjny będą poddane tendencjom do jej wyhamowania. W szczególności, silne przewagą 150 miliardów euro nadwyżki eksportowej w przemyśle motoryzacyjnym, osiagnniętą $\mathrm{z}$ tytułu nagromadzonego know-how w zakresie silnika spalinowego, Niemcy będą traktowały elektryfikację transportu w kategoriach bardziej defensywnych niż ofensywnych. Z kolei Chiny będą w tym upatrywały szansy, aby „przeskoczyć, nie doganiając”, czyli wykreować własny przemysł w nowej niszy technologicznej w opozycji do dzisiejszych potentatów. Kraje jak Polska, Norwegia czy Wielka Brytania - pozbawione rodzimych producentów - będą w zmianie technologicznej widziały możliwość inkubacji nowych podmiotów. Stanowiska USA i Francji, pozycjonujących się na przeciwległych biegunach w zakresie ambicji klimatycznych, będą do pewnego stopnia trybutariuszami tych wyborów.

Rozwój elektromobilności będzie postępował najlepiej tam, gdzie będzie odpowiedziq na oczekiwania społeczne. Kraje, w których społeczeństwa borykają się z zanieczyszczeniem powietrza, takie jak Chiny, Polska nie będą miały trudności z przekonaniem swoich społeczeństw do zalet czystego transportu. Również gęstość zaludnienia megamiast, takich jak Paryż, pomoże zbudować dla niego poparcie. Świadomości środowiskowa i klimatyczna przyczynią się do jego upowszechnienia, przynajmniej w niektórych stanach USA (np. w Kalifornii), w Niemczech i Norwegii. Przeszkodą będą możliwości finansowe społeczeństw, tonując rozwój kosztownych w zakupie pojazdów elektrycznych w uboższych 
społeczeństwach, jak Chiny czy Polska, a promując ich upowszechnienie w bogatych, jak Norwegia czy Kalifornia.

Potencjat tworzenia nowych miejsc pracy będzie największy w dynamicznie rozwijających się, zwłaszcza pod względem przemysłowym, krajach, jak Polska i Chiny. Dla Niemiec i Francji bilans w zakresie zatrudnienia będzie początkowo ujemny, powodując opór związków zawodowych, skonfrontowanych z utratą tradycyjnych miejsc pracy. Norwegia, Wielka Brytania będą miały utrudnioną sytuację. Pierwszy z nich ze względu na małą skalę przemysłu samochodowego, drugi ze względu na brexit, który pociaga za sobą znaczną niepewność dla firm lokujących się na Wyspach. Jednak ten ostatni argument może również wzmocnić determinację rządu do poszukiwania wszelkich możliwych sposobów wykreowania nowego zatrudnienia. Zważywszy na znaczenie i różnorodność rynku amerykańskiego globalna rewolucja technologiczna będzie tam wspierała miejsca pracy, nawet jeśli bilans w obrębie poszczególnych stanów będzie diametralnie zróżnicowany.

Dla wszystkich omawianych krajów bardzo ważne są możliwości umiędzynarodowienia, rozumiane jako zdolność do nawiązania produktywnych kooperacji międzynarodowych, jak również budowa wizerunku kraju, który pozytywnie rezonuje z elektryfikacją transportu. Szczególnie zyskają pionierzy, tacy jak Norwegia oraz największy rynek - Chiny. Niespójność w zakresie polityki klimatycznej pomiędzy rządem federalnym i niektórymi stanami, w szczególności Kalifornią, będą powodowały, że możliwość wykorzystania elektromobilności dla promocji Stanów Zjednoczonych nie będzie jednoznaczna.

Pozostaje jeszcze zdolność do inkubacji nowych graczy, która jest jednym z najtrudniejszych warunków do spełnienia, a jednocześnie warunkiem koniecznym dla sukcesu. W najlepszej sytuacji są gospodarki dojrzałe, o silnych kompetencjach, zaawansowanych więzach kooperacyjnych i posiadające zasoby kapitału wysokiego ryzyka, w szczególności USA. Przewagę mają również kraje, które obrały diametralnie inny model rozwoju, takie jak Chiny, mające silną tradycję etatyzmu, a jednocześnie narzędzia do jego ekspresji w sferze gospodarki. W najtrudniejszej sytuacji są kraje Unii Europejskiej skrępowane wspólnymi zasadami ochrony konkurencji. Francja, skonfrontowana od lat $\mathrm{z}$ wyzwaniami deindustrializacji, nie ma narzędzi inkubacji podmiotów przemysłowych. Gospodarka Niemiec jest również stosunkowo tradycyjna, choć udaje się zbudować nowe podmioty również w obszarze elektromobilności, choćby na potrzeby niemieckiej poczty. Znajdując się na środkowym etapie brexitu, Wielka Brytania nie będzie miała pełnej zdolności do wykorzystania wszystkich szans, jakie ofiaruje jej potencjał gospodarki i dostęp do finansowania. Na słabej pozycji są również Polska i Norwegia. 
Powyższe rozważania zostały ujęte w formie tabelarycznej, gdzie przyporządkowano im oceny na skali od najmniej sprzyjającej $(-)$, poprzez neutralną $(0)$ po dobrą $(+)$ i bardzo dobrą $(++)$.

Tabela 1. Schematyczna ocena perspektyw rozwoju elektromobilności dla wybranych państw

\begin{tabular}{|l|c|c|c|c|c|c|}
\hline & $\begin{array}{c}\text { Brak naturalnych } \\
\text { przeciwników } \\
\text { hamujących } \\
\text { rozwój } \\
\text { elektromobilności }\end{array}$ & $\begin{array}{c}\text { Odpowiedź } \\
\text { na wyzwania } \\
\text { i możliwości } \\
\text { społeczne }\end{array}$ & $\begin{array}{c}\text { Możliwość } \\
\text { tworzenia } \\
\text { nowych miejsc } \\
\text { pracy }\end{array}$ & $\begin{array}{c}\text { Potencjal } \\
\text { w sferze } \\
\text { międzynarodowej }\end{array}$ & $\begin{array}{c}\text { Zdolność } \\
\text { do inkubacji } \\
\text { nowych } \\
\text { graczy }\end{array}$ & Suma \\
\hline Polska & + & + & ++ & + & - & 4 \\
\hline Chiny & ++ & + & ++ & ++ & ++ & 8 \\
\hline Norwegia & + & ++ & 0 & ++ & - & 4 \\
\hline Niemcy & - & + & - & + & + & 1 \\
\hline USA & 0 & + & + & + & ++ & 4 \\
\hline Francja & 0 & + & - & + & 0 & 1 \\
\hline $\begin{array}{l}\text { Wlk. } \\
\text { Brytania }\end{array}$ & + & + & 0 & + & 2 \\
\hline
\end{tabular}

Skala od oceny najgorszej do najlepszej: $-, 0,+,++$

Źródło: opracowanie własne.

W efekcie wyłania się pewna hierarchia krajów posiadających najlepsze warunki do upowszechniania elektromobilności. Najlepiej spozycjonowane do skorzystania na rewolucji elektromobilności wydają się Chiny. Wielkość rynku, zdolność do wsparcia pionierów, korzyści wynikające z globalnej rewolucji technologicznej predestynują ten kraj do objęcia globalnego przywództwa w zakresie elektryfikacji transportu. Fakt, iż co drugi pojazd elektryczny na świecie sprzedaje się właśnie w Chinach i tutaj budują się największe fabryki ogniw litowo-jonowych, a przedsiębiorstwa, takie jak BYD, dominują na światowym rynku autobusów elektrycznych, potwierdza tę diagnozę. Wysoko w rankingu, i to z różnych powodów, sytuują się USA, Norwegia i Polska: USA jako globalny lider technologiczny i najbardziej innowacyjna gospodarka świata; Norwegia, silna bogactwem i oczekiwaniami swoich mieszkańców; Polska zaś skutecznie aspirująca do grona przemysłowych tygrysów XXI wieku. Wielka Brytania znajduje się w środku stawki, natomiast w najmniej sprzyjającej sytuacji wydają się znajdować Niemcy i Francja, gdzie elektromobilność oznacza konfrontację $\mathrm{z}$ tradycyjnym przemysłem w kontekście bardzo niepewnej walki o utrzymanie globalnej supremacji. 


\section{Podsumowanie}

Należy podkreślić, iż powyższe porównanie ma charakter poglądowy i schematyczny. Wymaga weryfikacji empirycznej. Jego wartością jest fakt, iż wskazuje na czynniki, które mogą zaważyć na sukcesie danego kraju i jego firm, nazwanej synergiczną kooperacją. Na przykładzie samej tylko elektromobilności pokazuje różne motywacje i różne bariery, które mogą stać się udziałem państw na drodze do sięgnięcia po realizację potencjału wartości, jaki wyłoni się z nałożenia się czterech trendów, które ukształtują przemysł samochodowy współczesności: autonomizacji, urbanizacji, cyfryzacji i elektryfikacji.

Wiele wskazuje bowiem, że to właśnie synergiczna współpraca pomiędzy państwem i sektorem prywatnym będzie warunkiem skorzystania z szans, jakie rysują się w zakresie nowej mobilności. W większości państw świata te szanse pozostaną niezagospodarowane, ale tam gdzie uda się po nie sięgnąć nagrodą będzie konkurencyjny przemysł, wysoko płatne miejsca pracy i globalna renta wynikająca z przewagi technologicznej.

\section{Bibliografia}

BCG. (2018). Analiza rynku elektromobilności i jego potencjału. Warszawa: The Boston Consulting Group.

CCAC. (2018). Briefing Paper by Climate and Clean Air Coalition for G7 Environment Ministers' Meeting on Urgent Action and Reduction Opportunities. Halifax, Canada: Climate and Clean Air Coalition.

Fukuyama, F. (2018). Against identity politics. Pozyskano z: https://www.foreignaffairs.com/ articles/americas/2018-08-14/against-identity-politics.

Hampleton Partners. (2018). Artificial Intelligence AI market report. Pozyskano z: https:// hampletonpartners.com/mediaarticle/hampleton-partners-artificial-intelligence-ai-marketreport/.

Harrari, Y. (2018). Homo Deus. Warszawa: Wydawnictwo Literackie.

IEA. (2018) Global EV Outlook. Paris: International Energy Agency.

Kurzweil, R. (2013). Nadchodzi osobliwość. Warszawa: Kurhaus Publishing.

Morgan Stanley. (2018). 5 acquisition trends investors should watch in 2018. Pozyskano z: https://www.morganstanley.com/ideas/5-acquisition-trends-investors-should-watchin-2018.

Piketty, Th. (2013). Le Capital au XXIe siècle. Paris: Edition de Seuil.

Roser, M. (2018). The short history of global living conditions and why it matters that we know it. Pozyskano z: www.ourworldindata.org.

UNGC (2016). Zrównoważone miasta. Życie w zdrowej atmosferze. Warszawa: United Nations Global Compact. Pozyskano z: http://ungc.org.pl/programy/zrownowazone-miasta/Miasta zrównoważone. 


\section{Polska na trasie chińskiego Jedwabnego Szlaku: szansa rozwojowa czy tylko wyzwanie?}

Idące do Europy dwa chińskie Jedwabne Szlaki, ogłoszone jesienią 2013 r., zaskoczyły nie tylko europejskie i światowe elity polityczne, lecz także środowiska akademickie. Ten bezprecedensowy projekt czy wizja chińskiego prezydenta Xi Jinpinga zwraca uwagę rozmachem i zasięgiem. Jest dowodem odrodzenia się Chin jako potęgi oraz ich globalnych ambicji. Celem tego opracowania jest pokazanie, jak do tego projektu odnoszą się kolejno elity państw Unii Europejskiej, regionu Europy Środkowo-Wschodniej, objętej inną chińska strategią 16+1 oraz w Polsce, która bezpośrednio na lądowym Szlaku się znalazła. Co z tą szansą Polska zrobiła? Z analizy wynika, że stosunkowo niewiele - mimo zauważalnej chińskiej obecności i interesów tu lokowanych. Jedwabne Szlaki pozostają więc dla Warszawy raczej niewykorzystaną, potencjalną szansą niż realną nową szansą rozwojową i aby to zmienić, potrzebna jest polityczna wola, której po polskiej stronie brak.

Słowa kluczowe: Belt and Road Initiative - BRI, strategia 16+1, Chiny, Europa, geopolityka, strategie rozwojowe, nowy ład ekonomiczny.

\section{Wprowadzenie}

Ogłoszony przez prezydenta Xi Jinpinga, jesienią 2013 r., w dwóch turach projekt, a raczej geostrategiczna wizja, zwana w oryginale Yidai, yilu, przestawiana najpierw jako One Belt, One Road (OBOR), a następnie - BRI (Belt and Road Initiative), czyli Inicjatywa Pasa i Szlaku, w chwili pojawienia się wzbudziła konsternację nawet w samych Chinach, nie mówiąc o świecie zewnętrznym. Oto kraj dotychczas trzymający się podyktowanej w początkach lat 90. minionego stulecia, przez wizjonera reform Deng Xiaopinga, formuły taoguang, yanghui, a więc budowy potęgi po cichu, bez zwracania niczyjej uwagi, wystąpił z bezprecedensowym projektem, którego wcielenie w życie może zmienić układ sił na świecie.

W Chinach szybko przekuto ten pomysł na konkrety: we wszystkich ważniejszych ośrodkach akademickich kraju powołano zespoły, katedry, a nawet 
instytuty badawcze mające stanowić naukowe zaplecze BRI, z podstawowym zadaniem, by wypełnić tę koncepcję konkretną treścią. Na samym początku tej drogi było bowiem tylko pięć propozycji prezydenta Chin dla krajów, które do projektu chciałyby się włączyć: koordynacja polityk, lepsze połączenia komunikacyjne (drogowe i kolejowe), otwarty handel, wymiana finansowa oraz zacieśnianie współpracy na szczeblu najniższym, między obywatelami ${ }^{1}$.

Dość szybko chińskie środowisko naukowe i tamtejsi eksperci pokazali, że chodzi tu o coś znacznie większego - by pokazać Chiny jako nowego geostrategicznego gracza, korzystającego ze swojego szybko rosnącego potencjału gospodarczego i finansowego, powracającego do statusu supermocarstwa oraz wielkiego ośrodka siły i pomysłów, jaki Chiny już kiedyś przez wieki posiadały (Maddison, 2007). A niektórzy przyznali nawet, że przy kreowaniu tej koncepcji Chiny sięgnęły do pomysłów „ojców geostrategii”, czyli Halforda Johna Mackindera i Nicholasa Spykmana, mówiących o łączącym Europę i Azję heartlandzie oraz otaczającym go łańcuchu mórz i oceanów, czyli rimlandzie (Xin Zhang, 2016, s. 28; szerzej na ten temat: Bartosiak, 2016. s. 70, 71). Cechą wyróżniającą tę koncepcję jest bowiem to, że oba Jedwabne Szlaki - lądowy i morski - zmierzają w kierunku zachodnim, przede wszystkim do Europy (choć z odnogami na Bliski Wschód i do Afryki, a z czasem okazało się, że niektóre projekty zainicjowano nawet w Tajlandii czy Indonezji).

Koncepcję OBOR, a potem BRI (chińska nazwa pozostała ta sama) przyjęto w świecie zewnętrznym, a przede wszystkim na szeroko rozumianym Zachodzie nie tylko z zaskoczeniem, lecz także z mieszanymi uczuciami. Owszem, pojawily się opinie, zgodnie z którymi BRI to „najbardziej znacząca i dalekosiężna inicjatywa, jaką Chiny kiedykolwiek przedstawiły" (Winter, 2016). Jednakże znacznie częściej stawiano tezy mówiące o tym, że oto na scenę światową wszedł nowy gracz wagi najcięższej, co naturalnie największą konsternację wzbudziło w USA, u dotychczasowego hegemona na scenie światowej.

Doskonałym dowodem na tę tezę jest książka Michaela Pillsbury'ego, który całe życie spędził w amerykańskim środowisku wywiadowczo-analitycznym zajmującym się Chinami. Po ogłoszeniu koncepcji OBOR wydał on tom o znamiennym tytule „Stuletni maraton”, w którym nawiązał do jeszcze innej, strategicznej koncepcji Xi Jinpinga, mówiącej o „dwóch celach na stulecie”. Pierwszy, na stulecie rządzącej Komunistycznej Partii Chin (KPCh), do realizacji zaś w połowie 2021 r., to zmiana tamtejszego modelu gospodarczego i oparcie go nie na eksporcie, jak było dotychczas, lecz na silnej i kwitnącej klasie średniej

Lądowy Jedwabny Szlak został ogłoszony 7 września 2013 r. w Astanie, natomiast morski Jedwabny Szlak ogłoszono 3 października 2013 r. na Bali w Indonezji (zob. Xi Jinping, 2014, s. 315,320 ). 
oraz dynamicznym rynku wewnętrznym. Drugi „cel na stulecie”, czyli okrągłą setną rocznicę proklamowania Chińskiej Republiki Ludowej (ChRL), a więc do wypełnienia na 1 października 2049 r., to nic innego, jak „wielki renesans chińskiego narodu", co wymaga spełnienia wielu poważnych wymagań, w tym kluczowego - pokojowego zjednoczenia z Tajwanem, bo przecież mamy do czynienia $\mathrm{z}$ dwoma organizmami z Chinami w nazwie 2 .

Zdaniem Pilsbury'ego i wielu innych ekspertów, te „dwa cele na stulecie”, połączone z BRI, to nic innego, jak wyłonienie się nowego geostrategicznego gracza, a zarazem najpotężniejszego rywala USA do pierwszoplanowej roli na globie. Przez dziesięciolecia, począwszy od wizyt Henry'ego Kissingera i prezydenta Richarda Nixona w ChRL w początkach lat 70. minionego stulecia, USA mocno się przyczyniały do tej sytuacji, co Pillsbury uznał zresztą za „bodaj najbardziej systematyczną, znaczącą i groźną porażkę wywiadu w amerykańskiej historii" (Pillsbury, 2016, s. 16).

\section{Percepcja BRI}

\subsection{W Unii Europejskiej (UE)}

Problemem jest, że chińskie Jedwabne Szlaki dość jednoznacznie pokazują nowego pretendenta do hegemonii na światowej scenie, co musi budzić zrozumiałą konsternację dotychczasowego hegemona, czyli USA. Narodziła się bowiem tym samym sytuacja nazwana przez ekspertów Uniwersytetu Harvarda „pułapką Tukidydesa”, kiedy to interesy dotychczasowego hegemona zderzają się z interesami pretendenta, co prowadzi najczęściej do wojny, niekoniecznie tylko handlowej. Podobnie dzieje się i teraz, szczególnie na Morzu Południowochińskim, kontrolowanym dotychczas przez flotę amerykańską, ale przy brzegach którego, w porcie Xiamen i paru innych miejscach rusza Morski Jedwabny Szlak, co zmusza Chińczyków do zwiększenia swej obecności, także militarnej, na tym akwenie. To obszar, gdzie „pułapka Tukidydesa” jest otwarcie zastawiona, a ścieranie się wpływów i interesów USA i ChRL zarówno tutaj, jak i na całej arenie międzynarodowej wydaje się być już nieuniknione ${ }^{3}$.

2 O nowym modelu: Góralczyk, 2017, s. 220-235. O nowej strategii: Góralczyk, 2018.

3 Pomysł pochodzi od emerytowanego i doświadczonego badacza i administratora z Harvardu, Grahama Allisona, który - wraz z zespołem - zbadał pod tym kątem okres od roku 1500 do współczesności. Badania wykazały, że „pułapek” było w tym czasie 16, z których 12 zakończyło się wojną (zob. Allison, 2017). W literaturze polskiej zob. Bartosiak, 2016, s. 554-663. 
Początki prawdziwej wojny handlowej, zainicjowanej wiosną 2018 r. przez administrację prezydenta Donalda Trumpa, stawiającego na hasło America First i w istocie izolacjonizm w handlu ${ }^{4}$, napotyka chińskie retorsje i zderza się z proponowaną i forsowaną przez władze ChRL polityką wolnego handlu, bez przeszkód i zahamowań, co tak silnie zaznaczył Xi Jinping w dwóch swoich głośnych wystąpieniach: na Forum Ekonomicznym w Davos w styczniu 2017 r. oraz na podobnym Forum w Boao w kwietniu 2018 roku (Xinhua, 2017; Xi Jinping, 2018).

OBOR, a następnie BRI przyjęte zostały z mieszanymi uczuciami również w UE i jej instytucjach, jak też zróżnicowały podejście do nich ze strony państw członkowskich w UE. W dostępnych już dzisiaj analizach ${ }^{5}$ wskazuje się, owszem, na nowe szanse i możliwości, idące w ślad za chińskimi koncepcjami i ich nową obecnością na terenie Europy, dotychczas nieznaną ani co do skali, ani - kapitałowego i inwestycyjnego - zaangażowania. Jeszcze częściej podkreśla się jednak, a w miarę upływu czasu argumenty te narastają i nabierają większej mocy, że chińska wizja ma poważne niedostatki i mankamenty takie przykładowo, jak: brak precyzji w przestawianych mapach i trasach BRI, forsowanie interesów własnych firm, brak przejrzystości proponowanych umów, sprzeczności proponowanych umów ze standardami i normami obowiązującymi w UE, niejasności dotyczące finansowania oraz publicznych przetargów dotyczących poszczególnych projektów, kwestie przestrzegania praw własności, zbyt duży nacisk kładziony na porozumienia dwustronne, z poszczególnymi państwami członkowskimi UE, które niemalże bez wyjątku cierpią na chroniczny deficyt handlowy z ChRL, czasami wyjątkowo wysoki, co prowadzi z jednej strony do ,asymetrii wpływów i oddziaływania”, a drugiej grozi realizacją przez Chiny strategii „,dziel i rządź” wśród państw członkowskich. Te opinie i zarzuty znalazły nawet dyplomatyczne odzwierciedlenie, kiedy to w kwietniu 2018 r. ambasadorzy państw UE w Pekinie, z wyjątkiem przedstawiciela Węgier, sformułowali na piśmie te zarzuty, począwszy od najpoważniejszego - że implementacja BRI grozi rozbiciem UE6.

Podstawowym mankamentem UE w stosunkach z Chinami - i ogólnie, „wschodzącymi rynkami” - jest brak spójnej i jednolitej strategii wobec nich, co tym bardziej prowadzi do asymetrii w świetle śmiałych wizji w ramach BRI.

4 Wstępne analizy: https://www.project-syndicate.org/bigpicture/trump-s-trade-war-expands (dostęp: 16.07.2018).

5 Dwie najlepsze i najbardziej wnikliwe, to: Godemont i. Vasselier, 2017; MERICS i Rhodium Group, 2017.

6 https://global.handelsblatt.com/politics/eu-ambassadors-beijing-china-silk-road-912258 (dostęp: 20.07.2018). 
Trzeba tak niestety stwierdzić, mimo przyjęcia przez Komisję Europejską w listopadzie 2013 r. strategicznej agendy współpracy w stosunkach dwustronnych z Chinami na okres do roku 2020 i umieszczenia w niej aż 94 „kluczowych inicjatyw" (EEAS, 2016) dotyczących tej współpracy w sferze nie tylko gospodarczej czy handlu, lecz także przykładowo w dziedzinie bezpieczeństwa i pokoju, w zakresie zrównoważonego rozwoju, współpracy naukowej i naukowo-badawczej czy turystyki i wymiany osobowej.

Drugi czynnik, który ujawnił się dosyć szybko po ogłoszeniu chińskiej Inicjatywy, to narastająca błyskawicznie chińska obecność inwestycyjna na terenie UE, która w roku 2016 sięgnęła 35 mld euro (skok aż o 77\% w stosunku do roku poprzedniego), podczas gdy unijna na terenie ChRL sięgnęła tylko 7,6 mld euro7. Co należy bowiem podkreślić i wyeksponować - już w rok po ogłoszeniu wizji OBOR chińskie inwestycje poza granicami kraju przewyższyły te do Chin przychodzące, które przynajmniej od 1992 r., czyli otwarcia Chin na globalizację po rozpadzie ZSRR, zawsze były wysokie. Tę zmianę trzeba uznać za przewrót iście kopernikański, a zrazem tutaj szukać wyjaśnienia, czemu prezydent Xi Jinping ze swą wizją BRI wyszedł - po prostu Chiny zaczynają mieć nadwyżki kapitałowe i inwestycyjne moce, które są i będą w stanie należycie spożytkować nie tylko u siebie, ale także na obcych rynkach.

I wreszcie trzeci, newralgiczny element: jak się szybko okazało, strona chińska nie tyle przychodzi do Europy i UE z nowymi inwestycjami typu greenefield, a więc pomysłami budowy nowych obiektów od samych fundamentów, lecz także jest zainteresowana operacjami typu fuzje i przejęcia, a raczej przede wszystkim przejęcia, najczęściej zresztą firm czy marek specjalizujących się w nowoczesnych i najnowszych technologiach. To właśnie przejęcie szwajcarskiego molocha chemicznego Syngenta za sumę szacowną na 65 mld dolarów, a następnie niemieckiej firmy Kuka, specjalizującej się w produkcji robotów przemysłowych (za sumę szacowaną na 5,5 mld euro) sprawiło, iż wszystkie państwa europejskie, w tym Niemcy, najbardziej zaangażowane we współpracę z Chinami, ostatecznie przekonały się, iż mają do czynienia z zupełnie nową chińską obecnością u siebie, w ramach której przejmowane są „najlepsze srebra rodowe”, jak to publicystycznie ujmowano. W efekcie nawet ówczesny niemiecki minister spraw zagranicznych Sigmar Gabriel zaczął zachęcać do ścisłej współpracy państw członkowskich UE i wypracowania przez nie wspólnej strategii w kontaktach z Chinami, albowiem - jak mówił - „jeśli nie uda się nam wypracować wspólnej strategii wobec Chin, to wtedy Chinom uda się podzielić Europę" (Godemont i Vasselier, 2017, s. 17).

7 A wszystko to przy ujemnym bilansie handlowym UE w tym samym roku rzędu 174 mld euro (zob. Godemont i Vasselier, 2017, s. 37). 
Dopiero przejęcia nowoczesnych firm oraz wysoka obecność inwestycyjna Chin na kontynencie europejskim do pewnego stopnia „obudziła” instytucje unijne oraz władze poszczególnych państw członkowskich. Wreszcie uświadomiono sobie, iż pomysł BRI rzeczywiście zaczyna być realizowany i nie może być w żadnej mierze ignorowany, jak to było na samym początku tuż po jego ogłoszeniu. Jego implementacja tworzy bowiem w stosunkach wzajemnych UE z ChRL zupełnie nową jakość, wymagającą od państw unijnych nowego namysłu, zastanowienia i prawdziwej strategii w tych zupełnie nowych okolicznościach.

Równocześnie jednak, co raczej zrozumiałe, władze unijne są ostrożne w przyjmowaniu chińskich sugestii, by „łączyć siły” w celu przeciwstawienia się inicjatywom administracji amerykańskiej Donalda Trumpa zmierzającym do ograniczeń w handlu. UE też na tych amerykańskich pomysłach traci, ale dość wyraźnie podkreśla, iż USA pozostają jej kluczowym, strategicznym partnerem. Innymi słowy, nawet groźba wojny handlowej nie oznacza jeszcze zmiany sojuszy czy nowej konfiguracji na scenie globalnej ${ }^{8}$. Tym samym UE mimo wszystko nie stawia na Chiny. A co na to państwa regionu EŚW?

\subsection{Percepcja BRI w regionie Europy Środkowej i Wschodniej (EŚW)}

Specyfika stosunków państw regionu EŚW z Chinami polega na tym, że państwa te rozpoczęły, też z inicjatywy Chin, wzmocnioną współpracę z ChRL jeszcze przed ogłoszeniem wizji BRI. Jeszcze poprzedni premier Wen Jiabao ogłosił bowiem w Warszawie w kwietniu 2012 r. koncepcję współpracy w ramach, wymyślonej w Pekinie, formuły $16+1$, czyli Chin z 16 państwami naszego regionu (czterema z Grupy Wyszehradzkiej, trzema Bałtyckimi oraz państwami bałkańskimi, z Rumunia, Bułgarią i Albanią oraz pojugosławiańskimi, bez Kosowa). Taki a nie inny skład 16 dowodzi, że Chiny nie za bardzo zważają ani na granice UE (11 członków, 5 kandydatów), ani - tym bardziej - strefy euro. Bardziej przekonująca dla nich była - i jest - bliskość geograficzna tych państw w słabo dotychczas rozpoznanym, a ważnym regionie u bram silnej Europy Zachodniej, jak też jego nieco zróżnicowane, ale wspólne doświadczenie „realnego socjalizmu" czy gospodarki planowej.

Pierwotnie strona chińska zaproponowała $\mathrm{w}$ ramach tej współpracy wizję „12 przedsięwzięć” czy kroków i wyasygnowała na te cele sumę 10 mld dolarów. Niewiele z tych planów udało się zrealizować, a niejako „okręt flagowy” tej współpracy, czyli szybka kolej łącząca Budapeszt z Belgradem (docelowo cho-

\footnotetext{
"We don't agree with Trump, but that doesn't mean we want to gang up on America with China, says EU adviser ahead of summit". Pozyskano z: https://www.project-syndicate.org/ bigpicture/trump-s-trade-war-expands (dostęp: 16.07.2018).
} 
dziłoby o połączenie portu w Pireusie, znajdującego się w rękach chińskiej firmy Cosco i wieńczącego, jak dotąd, Morski Jedwabny Szlak z Łodzią, czyli ważnym w chińskich planach komunikacyjnym centrum na drodze lądowego Jedwabnego Szlaku), nie jest realizowana do dziś, z racji oporu - i zarzutów - Komisji Europejskiej o „brak transparentności” (szerzej: Góralczyk, 2017, s. 153-162).

Dostrzegając problemy w ramach tej współpracy, jak też niechęć do niej otwarcie wyrażaną w instytucjach unijnych oraz najważniejszych stolicach państw członkowskich UE, począwszy od Berlina, strona chińska na szczycie $16+1$ w listopadzie 2016 r. Rydze, ustami szefa jej delegacji, premiera Li Keqianga, wyszła z kolejną, pięciopunktową propozycją współpracy. Zakładała ona: stymulowanie handlu, przyspieszenie budowy połączeń komunikacyjnych (zarówno infrastruktura, jak i logistyka), budowę chińskich parków przemysłowo-technologicznych w państwach 16 (jeden z nich powstał już poza nią, w Mińsku białoruskim), ożywienie wspólpracy finansowej (Węgierski Bank Narodowy jest zaangażowany $\mathrm{w}$ projekty badawcze nad umiędzynarodowieniem juana) oraz zwiększenie wymiany turystycznej i osobowej (Oehler-Sincai, 2018, s. 8).

Ta częściowa zmiana priorytetów niewiele jak dotychczas zmieniła: Chiny najwyraźniej nadal nie są zadowolone z tej współpracy. Choć początkowe założenia były inne i skoncentrowane na gospodarce oraz handlu, nadal poziom wspólpracy politycznej wyprzedza poziom wymiany gospodarczej. Albowiem jedynym wymiernym dotychczasowym osiaggnięciem w ramach inicjatywy $16+1$ jest powołanie jej Sekretariatu z siedzibą w Pekinie ${ }^{9}$ oraz doroczne szczyty, z których ostatni odbył się w Sofii w lipcu 2018 roku$^{10}$. Strona chińska zdaje się jednak coraz bardziej zmierzać do koncepcji przedstawionej przez prezydenta Xi Jinpinga wobec uczestników szczytu w Suzhou (listopad 2015), by „w pełni zintegrować" koncepcję 16+1 z BRI (Joić, 2017, s. 2). Pojawiają się również pomysły, by szczyty $16+1$ odbywały się nie - jak dotąd - corocznie, lecz raz na dwa lata, co dla wielu obserwatorów jest dowodem, iż projekt jednak nie za bardzo chwycit.

Natomiast przed ostatnim szczytem w Bułgarii głośno było o zaproszeniu nań także Niemiec. Jest to pomysł od pewnego czasu forsowany przez chińskich specjalistów zajmujących się Niemcami, którzy jednoznacznie traktują cały obszar EŚW jako niemiecką strefę oddziaływania w wymiarze politycznym i gospo-

9 Powstał też odrębny, koordynowany przez Polskę, sekretariat koordynujący współpracę logistyczną.

10 Uzupełnia je cała sieć innych spotkań i konwentykli: organizowane cztery razy do roku spotkania ambasadorów państw 16 w Pekinie, organizowane raz na pół roku (raz w Pekinie, raz w państwie organizującym doroczny szczyt) spotkania Narodowych Koordynatorów projektu, uzupełnione o spotkania think tanków i ekspertów. 
darczym. Dlatego też, jak sugerują, włączenie do ram $16+1$ Niemiec byłoby najlepszym sposobem na odsunięcie ich wyraziście formułowanych podejrzeń dotyczących prawdziwych motywów Chin w zaangażowaniu na tym obszarze (Zou Lu 2018, s. 8, 9).

Jest jeszcze inny, ważny element dowodzący nowej dynamiki wydarzeń wokół tego pomysłu, czyli nowy czynnik o charakterze geostrategicznym, jakim jest niekonwencjonalne zachowanie administracji i samego prezydenta Donalda Trumpa, tak w stosunkach z Chinami i regionie Azji i Pacyfiku, jak i transatlantyckich w ramach NATO oraz relacjach dwustronnych USA - UE. W tym właśnie kontekście strona chińska poszukuje nowych rozwiązań, czego dowodem wizyta szefa delegacji chińskiej, premiera Li Keqianga na szczycie w Sofii, bezpośrednio po nim w Berlinie, gdzie m.in. zapadła bezprecedensowa decyzja by niemiecki konglomerat BASF wybudował własną inwestycję o wartości rzędu 10 mld dolarów na południu Chin, bez udziału chińskiego kapitału, co jest rozwiązaniem zupełnie nowym i dotychczas na terenie ChRL nie stosowanym ${ }^{11}$.

Innym wartościowym osiągnięciem współpracy w ramach $16+1$ jest powołanie w kwietniu 2017 r. w Budapeszcie Instytutu Chiny - EŚW (China - CEE Institute) przez Chińską Akademię Nauk Społecznych (Chinese Academy of Social Science - CASS) w Pekinie, najpoważniejszy chiński think tank pracujący na rzecz władz, pierwszy w ogóle tego typu instytut badawczy poza Chinami. $\mathrm{Na}$ jego czele stanęli szefowie Instytutu Europy w CASS, którzy już wcześniej wykazali się największym zasięgiem badań nad $16+1$ oraz BRI (wraz z cenną serią wydawniczą) $)^{12}$ i są najcenniejszą pod tym względem placówką badawczą obok specjalnego Instytutu Badań nad Jedwabnym Szlakiem (China Silk Road Institute), powołanym w Pekinie przed pierwszym szczytem BRI (odtąd ma być organizowany co dwa lata). Instytut w Budapeszcie opublikował już dwie wartościowe serie working papers nt. współpracy w ramach inicjatyw 16+1 oraz BRI. Planowane są następne wydarzenia i publikacje, w tym książkowe ${ }^{13}$.

$\mathrm{Z}$ dostępnego dotychczas stanu badań wynika, że:

- państwa regionu EŚW, podobnie jak państwa całej UE, są dość mocno podzielone w stosunku do chińskich inicjatyw. Najbardziej pozytywnie odnoszą się do nich Węgry, Czechy i Rumunia oraz - ostatnio - obszar Zachod-

11 https:/cen.acs.org/business/petrochemicals/BASF-considering-10-billion-investment/96/ web/2018/07 (dostęp: 16.07.2018).

12 Trzy najcenniejsze jak dotąd prace, to: Liu Zuokui, 2017; Huang Ping i Liu Zuokui, 2017; Chen Xin, 2017.

13 W pierwszej transzy, opublikowanej w listopadzie 2017 r., było to kilkanaście opracowań, w drugiej, opublikowanej w czerwcu 2018 - ponad dwadzieścia. Są one dostępne na stronie: www.china-cee.eu i stanowią ważny materiał wykorzystany także w tym opracowaniu. 
nich Bałkanów, tzn. państw pojugosławiańskich, z wiodącą rolą pod tym względem Serbii. Natomiast bardziej wstrzemięźliwe są Polska, Państwa Bałtyckie, Albania czy Słowacja;

- znajdująca się w centrum w chińskich propozycji i zainteresowań współpraca inwestycyjna nie przynosi, jak dotąd, spodziewanych efektów, a chińskie inwestycje zmierzające do Europy są umieszczane przede wszystkim w Niemczech, Wielkiej Brytanii, Francji i Włoszech. Ostatnio, od roku 2017 widać też pewną nową dynamikę pod tym względem na terenie Zachodnich Bałkanów (zakłady metalurgiczne Smederevo, termy w Kostolac i pierwsza w kraju elektrownia wiatrowa w Serbii, fabryka samochodów elektrycznych Rimac i renowacja uzdrowiska Krapinske Toplice oraz most na półwyspie Pelješac w Chorwacji, inicjatywa „pięciu portów” obejmujących włoskie porty Triest, Wenecję, Ravennę, słoweński Koper i chorwacką Rijekę). Przy czym wszystkie badania i dane świadczą, że bezwzględnie pierwszym partnerem Chin na terenie Zachodnich Bałkanów jest Serbia, drugi kraj w ramach 16, obok Węgier, mający wyraźną wolę polityczną by tę współpracę rozwijać, co tym bardziej kontrastuje z odczuwalnym w regionie, w tym w Polsce, rozczarowaniem stanem dotychczasowej wspólpracy;

- jeśli chodzi o dotychczasowe chińskie inwestycje w regionie EŚW, to nadal rolę wiodącą odgrywają tu jednak państwa wyszehradzkie, w tym Czechy (34\% całości 16, gdzie chińskie firmy przejęły tamtejsze linie lotnicze, klub sportowy Sparta Praha, dwa luksusowe hotele w centrum Pragi, a negocjowane jest przejęcie wielkiego browaru), Węgry (19\%, głównie przejęcie konglomeratu chemicznego Borsodchem przez spółkę Wanhua) oraz Polska (9\%) (Lin Yue, 2018, s. 12, 13).

- tylko Węgry w regionie mają wyraźną, prowadzoną od 2011 roku strategię wobec Chin i partnerów na Wschodzie, zwaną keleti nyitás (otwarcie na wschód), która jednakże nie przyniosła, jak dotąd, spodziewanych efektów, chociaż politycznie mocno zbliżyła oba kraje. Dostępne badania pokazują też, że to Węgry są na czele listy państw 16, w których organizowanych jest najwięcej imprez i wspólnych przedsięwzięć z Chinami;

- dotychczasowe doświadczenie współpracy w ramach 16+1 dowodzi, iż przebiega ona niemal wyłącznie na zasadzie porozumień dwustronnych poszczególnych państw 16 z Chinami i nie przyniosła żadnej nowej jakości we współpracy regionalnej (niezrealizowany projekt szybiej kolei łączącej Budapeszt z Belgradem, projekt „pięciu portów” jedynie na papierze itp.). Co więcej, w wielu krajach 16 konterwersje budzą też chińskie warunki kredytowania proponowanych inwestycji, w tym znacznego udziału ich przedstawicieli i firm na budowach. To samo dzieje się zresztą po stronie unijnej, 
która wyszła nawet ostatnio z porpozycją screeningu, a więc uważnego monitorowania chińskich kontraktów i inwestycji na jej obszarze.

\subsection{Percepcja BRI w Polsce}

Ani koncepcja $16+1$, chociaż narodzona i ogłoszona w Polsce, ani idącą w ślad za nią, już nie regionalna lecz globalna w swym wymiarze, BRI nie znalazły się w centrum zainteresowania polskiej polityki zagranicznej (Stanzel, Kratz, Szczudlik i Pavlićević, 2016). Jest to wyraźny mankament, ponieważ, zdaniem autora niniejszego opracowania, po raz pierwszy w długich chińskich dziejach (nie licząc krótkiego epizodu jesienią 1956 r., gdy władze w Pekinie stanęły po stronie Władysława Gomułki) w interesie Chin leży rozwój współpracy z Polską. A to z tego powodu, że Polska znalazła się na głównej osi lądowego Jedwabnego Szlaku prowadzącego z Chin centralnych, przez Xinjiang, Kazachstan, Rosję i Białoruś, aż do Europy Zachodniej (Amsterdamu, Rotterdamu czy Hamburga).

Polska posiada niezbywalny atut w stosunkach $\mathrm{z}$ nabierającymi globalnego rozmachu Chinami w postaci swego miejsca na mapie. To, co było naszym prawdziwym przekleństwem przez wieki, położenie między Rosją a Niemcami, z chłodnego oglądu Chin jest najlepszym możliwym atutem geostrategicznym. Warto byłoby go należycie wykorzystać, ale - jak dotąd - udało się nam osiągnąć sukcesy jedynie w sferze politycznej, a znacznie mniej w gospodarczej, choć z założenia powinno być odwrotnie.

Na stosunkach demokratycznej Polski z Chinami na dość długo zaciążyła jedna data - 4 czerwca 1989 roku - gdy w Chinach doszło do siłowego rozwiązania głębokiego kryzysu na placu Tiananmen, a w Polsce w tym samym dniu doszło do pierwszych, ograniczonych, ale częściowo demokratycznych wyborów, które już we wrześniu tego roku przyniosły pierwszy demokratyczny rząd w państwach byłego bloku wschodniego, czyli gabinet premiera Tadeusza Mazowieckiego. Data ta stała się niejako „kamieniem węgielnym” stosunków dwustronnych, mocno je - ideologicznie - obciążając, mimo że Chiny podchodzą do współpracy z innymi państwami pragmatycznie, a nie ideologicznie (Góralczyk, 2009, s. 399). Przez następne dwie dekady, co najmniej do wielkiego kryzysu na światowych (czytaj: zachodnich) rynkach, podejście demokratycznej Polski do autorytarnych Chin było przesycone swego rodzaju mesjanizmem czy poczuciem wyższości (nowej demokracji nad autokratycznym - i przebrzmiałym - „realnym socjalizmem”).

Sytuacja zmieniła się dopiero na przełomie pierwszej i drugiej dekady XXI wieku, częściowo z racji kryzysu 2008 r., a chyba jeszcze w większym stopniu z powodu powolnego uświadamiania sobie przez cały Zachód szybko rosną- 
cej roli ChRL jako gospodarczego i handlowego giganta. Politycznym przełomem okazała się wizyta w Chinach prezydenta Bronisława Komorowskiego pod koniec 2011 r., kiedy podpisano porozumienia i podniesiono wzajemne relacje do poziomu strategicznych. Natomiast w trakcie wizyty prezydenta Xi Jinpinga w Polsce w czerwcu 2016 r. podniesiono stosunki dwustronne do poziomu najwyższego z możliwych: rozwiniętego partnerstwa strategicznego (comprehensive strategic partnership) (Xinhua, 2016). Wysoki poziom dialogu politycznego na najwyższym szczeblu podtrzymały: wizyta prezydenta Andrzeja Dudy na szczycie w 16+1 w Suzhou (choć organizowana na szczeblu premierów, strona polska, wykorzystując czas zmiany własnej administracji, wysłała tam prezydenta, na co strona chińska odpowiedziała - organizacją ad hoc wizyty oficjalnej polskiego prezydenta, dowodząc wagi przykładanej do wzajemnych relacji) oraz udział polskiej premier Beaty Szydło na pierwszym szczycie BRI w Pekinie w maju 2017 roku.

Niestety, towarzyszące tym wizytom porozumienia (zresztą, nie zawsze tak było), w tym blisko 40 podpisanych podczas wizyty chińskiej głowy państwa w RP albo nie zostały zrealizowane, albo były mocno spowalniane. Do rangi symbolu urosła decyzja szefa polskiego MON, by nie udzielić stronie chińskiej zgody na zakup działki należącej do Agencji Mienia Wojskowego, na której strona chińska zamierzała pobudować - kluczowe w swoich planach - centrum komunikacyjne na lądowym Jedwabnym Szlaku.

Rozwiązanie, jakie zastosowano w efekcie tej polskiej decyzji, czyli podpisanie porozumień na szczeblu samorządowym i przeniesienie chińskiego transportu kolejowego z Łodzi do pobliskiego Kutna dowodzi jednak, po pierwsze, skuteczności i determinacji strony chińskiej, a także, po drugie, jej dużego pragmatyzmu. Polska jest w chińskich planach ważnym ogniwem tak w ramach $16+1$, jak i BRI i ma nim pozostać. $\mathrm{W}$ efekcie, mamy do czynienia $\mathrm{z}$ wieloma chińskimi przedsięwzięciami na terenie RP, najczęściej o charakterze lokalnym, w wyniku porozumień z tamtejszymi władzami.

$\mathrm{Na}$ plan pierwszy należy wysunąć kwestię połączeń kolejowych. Albowiem akurat pod tym względem Polska odgrywa rolę nie tylko centralną, lecz wręcz pionierską w regionie. A to dlatego, że jeszcze przed ogłoszeniem inicjatyw $16+1$ oraz BRI ulokowana w Łodzi firma Hatrans wyszła z propozycją wykorzystania połączeń kolejowych dla rozwoju kontaktów handlowych z Chinami. Pierwsze składy pociągów z Chengdu w prowincji Sichuan przybyły, po blisko dwutygodniowej podróży do Łodzi 2 stycznia 2013 roku. Połączenia w obu kierunkach zainicjowano w maju tegoż roku, uzupełniając inne głośne i ważne połączenie z Chinami na linii Chongqing - Duisburg, otwarte w roku 2011. Regularne połączenia składów towarowych na tej trasie rozpoczęto $\mathrm{w}$ roku 
2015. Przy czym w początkowej fazie towary szły niemal wyłącznie w jednym kierunku - z Chin do Polski (Czerep, 2017; szerzej i wnikliwiej na ten temat: Jakóbowski, Popławski i Kaczmarski, 2018, s. 1, 12). Dopiero po roku 2015 sytuacja zaczęła się nieco zmieniać i również składy zmierzające do Chin, zarówno z Łodzi, jak i z Kutna, zaczęły być załadowywane przede wszystkim towarami rolnymi, jak owoce (głównie jabłka) czy przetworzone warzywa, a z czasem też towary chemiczne i przemysłowe. Ocenia się, że na koniec roku 2017 do Lodzi i Kutna przybywało ok. $25 \%$ całości towarów trafiających drogą kolejową do UE, a tymczasem dynamika obrotów kolejowych między Chinami a UE wzrosła w minionej dekadzie stukrotnie.

Jeszcze przed inauguracją połączeń kolejowych, co też trudno uznać za prawdziwy przypadek, już w 2009 r. chińska firma Covec wygrała przetarg na budowę odcinka autostrady pomiędzy Łodzią a Warszawą, co było pierwszym tego typu eksperymentem w wykonaniu chińskiej kompanii na terenie UE. Przedsięwzięcie to nie zakończyło się jednak sukcesem, Covec zmuszony był najpierw z polskiego rynku się wycofać, a następnie zapłacić odszkodowanie. Okazało się, że zderzyły się ze sobą odmienne mentalności biznesowe: Chińczycy zawierzyli porozumieniom i zapewnieniom politycznym na wysokim szczeblu, uznając tym samym, że posiadają należyte guanxi, a więc powiązania z należytymi czynnikami i osobami i nie dokonali właściwego rozeznania rynku (weszli bez feasibility study), a następnie zderzyli się z wymogami unijnymi i wolno napływającymi pieniędzmi, co wznieciło bunt polskich podwykonawców dla Covec. Innymi słowy, chińska mentalność oparta na osobistych relacjach i powiązaniach zderzyła się z unijnym porządkiem biurokratycznym i instytucjonalnym: u nich liczą się osoby i stanowiska, u nas (czytaj: w UE) instytucje, reguły i regulacje prawne.

Klęska Covec jednak Chin nie zniechęciła. Wręcz przeciwnie, jeszcze zwiększyły one swoją obecność w Polsce i w regionie, traktując przypadek tej firmy jako wypadek przy pracy, a zarazem cenne doświadczenie na trudnym i wymagającym rynku unijnym.

\section{Korzyści i ryzyka związane z BRI}

\subsection{Potencjalne korzyści}

Drugim obszarem, obok połączeń kolejowych i perspektywy wykorzystania szybkich chińskich kolei do połączeń w regionie (Budapeszt - Belgrad) są pierwsze kontrakty na chińskie inwestycje w sektorze energetycznym na 
obszarze EŚW. Największy i najbardziej zaawansowany pośród nich jest blok energetyczny w elektrowni Cernavoda II na terenie Rumunii, którego kontrakt opiewa na 7 mld euro i ma być sfinalizowany już w roku 2019. Inne podpisane porozumienia dotyczą elektrowni atomowych Temelin - Dukovany w Czechach (ok. 15 mld euro, ale do uruchomienia dopiero w trzeciej dekadzie tego stulecia) oraz Belene w Bułgarii. W tym kontekście zwracają uwagę również pierwsze chińskie projekty i inwestycje na terenie Polski, realizowane na szczeblu lokalnym, jak budowa trakcji elektrycznych w okolicach Słupska, Szczecina, Chełma i Lublina przez chińskie konglomeraty China State Grid (dwa pierwsze) oraz Sinohydro (dwa pozostałe).

Do dwóch wcześniejszych inwestycji, a raczej przejęć - w hucie Stalowa Wola przez firmę Liugong oraz Fabryki Łożysk Tocznych w Kraśniku przez Tri Gong - w ostatnich latach doszły takie przejęcia, jak przez China Everbright Intl. firmy Novago w Mławie specjalizującej w utylizacji odpadów czy firm Hongbo pod Opolem (oświetlenie led), Nuctech w Kobyłce (osprzęt na lotniskach), a także budowa montowni telewizorów TCL pod Żyrardowem, składalni rowerów w Koszalinie (Athletic Group) czy produkcja świec pod Tarnowem (Dalian Talent) (Sarek, 2017, s. 70-73).

Jak widać i co można udowodnić, chińska obecność gospodarcza i inwestycyjna w Polsce stale rośnie, ale ma raczej charakter wybiórczy i punktowy. Ani nie jest powszechna, ani odgórnie forsowana. Większość porozumień, mimo doskonałych relacji politycznych na najwyższym szczeblu, jest podpisywana na szczeblu lokalnym czy samorządowym. Jako takie trudno uznać je za niosące do Polski chiński model rozwojowy czy nawet tamtejsze rozwiązania w polityce przemysłowej lub zarządzaniu. Nadal należy je uznawać za przedsięwzięcia o ograniczonym charakterze. Brakuje w naszych stosunkach dwustronnych jakiejkolwiek poważnej inwestycji (w obu kierunkach), którą można byłoby uznać za symboliczną. Natomiast rozważania o zaangażowaniu chińskiego kapitału w budowę Centralnego Portu Lotniczego ulokowanego między Warszawą a Łodzia, jak dotąd należy bardziej uznać za spekulacje medialne niż realne porozumienia.

Jednakże najważniejszym, niezbywalnym atutem w stosunkach dwustronnych Polski z Chinami jest fakt, że strona chińska wyszła z dwoma śmiałymi projektami, najpierw współpracy z państwami naszego regionu w formule 16+1, a następnie w ramach wizji BRI. Chociaż nie wiadomo jak dalej potoczą się losy oby tych projektów i czy - z chińskiej woli - nie dojdzie pomiędzy nimi do fuzji, to jednak wszystko wskazuje na to, że zainteresowanie Chin Europą i UE, w tym Polską pozostanie trwałe, a nawet może się zwiększyć z racji ostatnich amerykańskich wizji izolacjonistycznych oraz widma wojny handlowej. 
Ten ostatni czynnik, ze względu na specyfikę polskich relacji i sojusz z USA, nie ułatwi zapewne stosunków z nowym graczem w naszym regionie, jakim stały się Chiny, ale z całą pewnością zmusza do podejmowania bardziej kreatywnego i strategicznego w wymiarze myślenia także w Warszawie.

Strona chińska bezustannie podkreśla, że BRI ma jak najbardziej otwarty charakter, praktycznie może do tego projektu przystąpić każdy, kto chce. Natomiast Polska nie tylko może, ale powinna do niego przystąpić z trzech podstawowych powodów: 1) lokalizacji; 2) płynących z punktu (1) chińskich interesów związanych z naszym krajem; 3) największego w regionie EŚW potencjału. Jednakże stopień tego zaangażowania powinien być stale starannie mierzony i dozowany, albowiem mamy do czynienia z niesymetrycznością potencjałów i mocy. Chiny to nowy globalny gracz ze swoimi interesami, a Polska jest - i powinna być - ulokowana na Zachodzie, tak pod względem bezpieczeństwa (NATO), jak i w sferze gospodarczej (UE, Niemcy), chociaż w tej drugiej właśnie BRI dowodzi, jak ważnym graczem w praktycznie wszystkich obszarach na świecie, włącznie z naszym regionem $(16+1)$ stały się Chiny. Najwyższy czas, by wyciągnąć stąd w Warszawie należyte wnioski.

\subsection{Potencjalne rodzaje ryzyka}

Podstawowy problem Polski i innych krajów regionu EŚW w stosunkach z Chinami są niesymetryczne relacje. Mamy do czynienia z partnerem wyrastającym na nowe supermocarstwo, drugą gospodarką świata (pierwszą w sensie siły nabywczej pieniądza) i państwem po 2012 r. z otwartą przyłbicą głoszącym, że zamierza być numerem jeden na świecie, nie tylko w wymiarze gospodarczym czy handlowym. Tym samym stosunki z tym partnerem mają charakter geostrategiczny i wymagają głębokiego, strategicznego namysłu.

Polska jest i pozostanie członkiem sojuszy zachodnich (NATO) i, podobnie jak państwa regionu, jest gospodarczo uzależniona od rynków UE oraz przede wszystkim od Niemiec. Tym samym ściślejsze stosunki z Chinami mogą budzić podejrzenia naszych sojuszników, począwszy od USA, jak też naszych partnerów handlowych, począwszy od Niemiec. Trzeba te czynniki brać pod uwagę we wszystkich porozumieniach i kontaktach z Państwem Środka. Tak po prostu dyktują prawa strategii i geostrategii.

Chińskie inicjatywy $16+1$, a następnie BRI sprawiły, że mimo woli Polska i nasz region weszły do wielkiej gry, albowiem Chińczycy nie tylko pojawili się na naszych rynkach, ale mają też tutaj swoje interesy i pola oddziaływania. Tymczasem - przykładowo - mocno forsowane przez Chiny projekty infrastrukturalne $\mathrm{w}$ wielu przypadkach stoją $\mathrm{w}$ sprzeczności $\mathrm{z}$ forsowaną przez UE siecią 
TENT (Tran-European Transport Network), co raz jeszcze dowodzi kontrowersji związanych z ewentualnymi porozumieniami ze stroną chińską. W przypadku Polski wymaga to namysłu i zastanowienia czy opowiadamy się za unijnym projektem korytarza Bałtyk - Adriatyk i czy chcemy szukać synergii między projektem forsowanym przez polskie władze, a szczególnie prezydenta, by budować Trójmorze a podobnymi propozycjami chińskimi, mającymi na celu łączenie morskiego i lądowego Jedwabnego Szlaku. Można te inicjatywy traktować rozłącznie, a można też próbować je łączyć: wybór należy do nas.

$\mathrm{Z}$ kolei w wymiarze czysto ekonomicznym największym naszym problemem jest chroniczny deficyt państw naszego regionu z Chinami, a inicjatywy $16+1$ oraz BRI niewiele pod tym względem zmieniły, Według danych chińskich, w okresie 2010-2016 chiński eksport do regionu EŚW wzrósł o 22,74\%, z 53,09 do 65,17 mld dolarów, natomiast import wzrósł co prawda w tym czasie o 41\%, ale zamyka się o wiele mniejszymi sumami - z 6,89 do 9,72 mld dolarów. Ponadto obroty te w ostatnich latach stanowią jedynie ok. $10 \%$ obrotów handlowych całej UE z Chinami, a ujemne saldo w handlu zwiększyło się w tym czasie z 46,2 do 55,45 mld dolarów (Deng Jing i Liu Xiaojing, 2018, s. 2, 3). Sprawa jest na tyle poważna, że trafiła do dokumentu końcowego po ostatnim szczycie 16+1 w Sofii (Szczudlik-Tatar, 2018).

Deficyt ten jest również podstawową bolączką w kontaktach Polski z Chinami. W okresie 2009-2017 wzrósł ponad dwukrotnie, z 9 do 14,5 ml dolarów i w ten sposób przykrył niewątpliwy sukces Polski, jakim był najwyższy w historii eksport polskich towarów do Państwa Środka w 2017 r. w wysokości 3,35 mld dolarów, zwiększając się ponad trzykrotnie w stosunku do poziomu sprzed uruchomienia formuły 16+1. Według danych Głównego Urzędu Celnego ChRL, nie do końca zbieżnych z podawanymi przez polski GUS, dwustronne obroty handlowe zwiększyły się w okresie 2012-2017 z 12,3 do - po raz pierwszy historii - poziomu ponad 20 mld dolarów według danych chińskich (17,85 według GUS $)^{14}$.

Niejednoznaczność w statystykach dotyczących handlu z Chinami polega na tym, że poważna jego część idzie przez Hongkong oraz raje podatkowe typu Kajmany czy Wyspy Dziewicze. Tym samym trudniej o zdobycie jednorodnych i bardziej precyzyjnych danych. natomiast podstawowy problem, jakim jest poważny deficyt w handlu, w naturalny sposób kładzie się wielkim cieniem na całości naszych dwustronnych stosunków. Według obliczeń jednego chińskich autorów, skumulowany deficyt Polski w handlu z ChRL w okresie 2008-2016 wyniósł 154,4 mld dolarów(Lin Yue, 2018, s. 9).

14 https://www.bankier.pl/wiadomosc/Eksport-z-Polski-do-Chin-najwyzszy-w-historii-7568470.html (dostęp: 16.07.2018). 
Taki stan rzeczy niepokoi, bo musi niepokoić. Tym bardziej, że w chińskiej ofercie towarowej jest coraz więcej towarów wysoko przetworzonych, w tym wysokich technologii, podczas gdy w naszej dominują surowce lub towary nieprzetworzone, dopiero w ostatnim czasie uzupełnione o chemikalia czy wyroby farmaceutyczne. Tak oto kraj, któremu UE (wraz z USA) nie chce nadać statusu gospodarki rynkowej oraz mianowany „państwem rozwijającym się” eksportuje towary wyższej jakości do obszaru formalnie należącego do UE, a więc jednego z najbardziej rozwiniętych na świecie.

To nie jedyny paradoks dowodzący tego, by jak najszybciej przewartościować swoje podejście do Chin. Tymczasem, jak już wspomniano, jedynie Węgry mają w regionie wypracowaną strategię współpracy z Chinami i polityczną wolę jej kontynuacji, natomiast jedynie Słowacja - kraj o słabo rozwiniętej skali współpracy z Chinami - wypracowała specjalny Plan Akcji na okres 2017-2020, uzupełniony o rządową Koncepcję rozwoju relacji gospodarczych z ChRL (Kironská i Turcsányi, 2017, s. 9). Podczas gdy takie dokumenty na pewno przydałyby się we wszystkich państwach EŚW.

W Polsce regularne analizy na temat Chin na szczeblu centralnym prowadzą, na dobrym poziomie, ale w daleko niewystarczającym stopniu, zaledwie dwa ośrodki: Polski Instytut Spraw Międzynarodowych (PISM) oraz Ośrodek Studiów Wschodnich (OSW). Pierwszy skoncentrowany jest na badaniu całości polityki zagranicznej państwa, w ramach której podejście do Chin czy wschodzących rynków odgrywa jedynie marginalną rolę (zaledwie dwójka analityków zajmujących się wyłącznie Chinami), a drugi skoncentrowany jest o wiele bardziej na obszarach poradzieckich, aniżeli regionie Azji Wschodniej. Tymczasem to ten ostatni - obok Chin i Tajwanu także obie Koree czy Japonia - odgrywa coraz większą rolę na arenie międzynarodowej, już nie tylko w wymiarze gospodarczo-handlowym, lecz także jak najbardziej strategicznym. Warto byłoby z tego wyciągnąć należyte wnioski i jak najszybciej utworzyć specjalny zespół czy nawet instytut analityczny zajmujący się wyłącznie tym obszarem i jego znaczeniem, co byłoby zapewne spełnieniem dobrze rozumianych interesów naszego kraju.

\section{Podsumowanie}

Tak zwana piąta generacja przywódców ChRL z Xi Jinpingiem na czele, u władzy od końca 2012 r., zerwała z poprzednią polityką skromności i (od) budowy własnej potęgi po cichu, bez zwracania uwagi świata zewnętrznego, jak postulował w swym politycznym testamencie wizjoner najpierw prorynkowych 
reform (1978), a potem włączenia Chin w globalizację (1992) Deng Xiaoping. Nowa ekipa wyszła $\mathrm{z}$ bardzo śmiałymi projektami tak na scenie wewnętrznej („dwa cele na stulecie”), jak i międzynarodowej, w postaci OBOR - BRI. Od tej chwili należy traktować relacje z Chinami jako nowo wyłaniającym się mocarstwem, mającym wpływ na układ sił na świecie, poprzez swoją wagę i rangę przywracającym nowy multipolarny ład światowy, z Chinami mającymi coraz więcej do powiedzenia w wielu dziedzinach, także w sferze modeli rozwojowych, o czym traktuje ten tom, a czemu - jak wykazuje niniejsza analiza - strona polska najwyraźniej nie przypisuje należytej wagi.

Poprzedzająca wizję BRI koncepcja 16+1 z 2012 r. jest dobrą platformą współpracy Chin $z$ danym regionem, chociaż od początku budziła podejrzenia czy kontrowersje o stosowanie przez Chiny zasady „dziel i rządź” czy to w USA, czy instytucjach unijnych oraz najważniejszych stolicach państw UE, począwszy od Berlina, jako że - jak wykazują dostępne statystyki i dane - cały region EŚW jest mocno gospodarczo i handlowo uzależniony od Niemiec. Ten czynnik trzeba stale uwzględniać w polskich kalkulacjach, mając na uwadze jakikolwiek rozwój stosunków z Chinami, partnerem pożądanym, bo mającym u nas swoje interesy, a na dodatek bogate zasoby kapitałowe i własne projekty oraz propozycje.

Właśnie uwarunkowania zewnętrzne sprawiają, iż w żadnej mierze nie dziwi fakt, że z chwilą wprowadzenia nowej dynamiki, a raczej turbulencji do stosunków tak z Chinami, jak i z UE przez nową administrację amerykańską Donalda Trumpa, u władzy od stycznia 2017, już nie tylko niektóre państwa 16 (jak Estonia, Litwa czy Albania) zaczęły się wahać co do swego dalszego udziału w tym formacie, ale zaczęli się zastanawiać nad sensem jego dalszego funkcjonowania w tej formule sami pomysłodawcy, czyli Chińczycy, o czym świadczą - nigdy oficjalnie nie potwierdzone, ale też nie zanegowane przez Pekin - koncepcje a to urządzania szczytów $16+1$ nie raz do roku, lecz raz na dwa lata (następny zapowiedziano w Chorwacji, ale bez daty), a to włączenia do nich najbardziej „drażliwych” Niemiec. Coraz więcej sygnałów napływających z Chin wskazuje również na to, iż formuła $16+1$ stanie się integralną częścią BRI.

Stanie się tak przede wszystkim dlatego, że w odpowiedzi na amerykańskie koncepcje unilateralizmu, protekcjonizmu, a nawet wojny handlowej w wykonaniu administracji Donalda Trumpa, strona chińska coraz mocniej forsuje własne, czyli wsparcie globalizacji oraz zasad wolnego handlu i reguł obowiązujących w WTO. Co więcej, przywódcy chińscy, w opozycji do projektu America First, zaczynają promować koncepcję community of shared destiny, a więc opartej na płynącej z sił globalizacji wspólnocie interesów, gdzie na dodatek ma dominować - według Pekinu - zasada obopólnych korzyści (win-win), co jednak nie wszyscy partnerzy Chin przyjmują jako dobrą monetę. 
Takie podejście Chin oraz ich rosnący potencjał, także inwestycyjny (od 2014 r. inwestycje z Chin wychodzące są większe od tych, które do nich przychodzą) sprawiają, że dosłownie każde państwo na świecie powinno przeprowadzić swoisty rachunek sumienia w stosunkach z tym nowym kolosem. Jak najbardziej dotyczy to także Polski, najważniejszego państwa w regionie EŚW, na dodatek położonego na głównej trasie lądowego Jedwabnego Szlaku rysowanego przez Chiny. Obok, zainicjowanych przez stronę polską, transportów kolejowych między oboma krajami, są to dwa niezbywalne atuty naszego kraju w stosunkach z Chinami, które na dodatek, kierując się oczywiście własnymi interesami, nie tylko chcą przyjść do Polski, ale rzeczywiście przychodzą - jako inwestor i nowy gracz.

Niestety, jak dowodzi niniejsza analiza, bardzo dobra sieć relacji na najwyższym szczeblu politycznym w tym wizyty prezydentów obu krajów nawzajem u siebie, nie zostały, jak dotąd, przekute w prawdziwy sukces gospodarczy, a Polska nadal zmaga się $\mathrm{z}$ chronicznym deficytem $\mathrm{w}$ handlu $\mathrm{z}$ tym partnerem, natomiast nowe porozumienia i umowy podpisuje bardziej na szczeblu lokalnym niż ogólnokrajowym. Aktualne władze w Polsce po pierwszym zachwycie w relacjach z nowym mocarzem najwyraźniej spowolniły współpracę z Chinami, co należy rozumieć częściowo jako odpowiedź na zupełnie nową dynamikę stosunków w trójkącie USA - UE - Chiny. Podobnie jak nieobojętne oczywiście dla kształtu naszych dwustronnych relacji są - bardzo ścisłe jak dotąd - powiązania i wspólpraca Chin z Rosją, traktowaną w Warszawie jako nasz największy antagonista.

Nie zmienia to jednak faktu, że zakrojona na wielką skalę koncepcja BRI jest i będzie przez Pekin forsowana, a Polska jest w tamtejszych kalkulacjach brana pod uwagę jako ważny partner. Warto byłoby te nasze atuty właściwie wykorzystać. Do czego jednak niezbędna jest zarówno polityczna wola, jak i szersze zaplecze eksperckie decydentów, zdolne do wypracowania - wręcz niezbędnej w obecnych okolicznościach - strategii stosunków z Chinami. Taki potencjał w sensie osobowym posiadamy. Potrzebna jest tylko wyobraźnia i polityczna wola, by go wykorzystać.

\section{Bibliografia}

Allison, G. (2017). Destined for War. Can America and China Escape Thucidydes Trap? New York: Houghton Mifflin Harcourt.

Bartosiak, J. (2016). Pacyfik i Eurazja. O wojnie. Warszawa: Wydawnictwo CSPA. 
Chen Xin. (red.). (2017). How Hungary Perceives Belt \& Road Initiative and China-CEEC Cooperation. Beijing: China Social Sciences Press/CASS.

Czerep, J. (2017). Influence of the Lódź-Chengdu railway on the perception of $16+1$ in Poland. China - CEE Institute Working Paper, No. 5, Budapest, 15 listopada.

Deng Jing i Liu Xiaojing, (2018). Deepening the "16+1 cooperation" relationship to foster the new growth pole of Sino-EU Trade. China - CEE Institute Working Paper, No. 13, 22 czerwca.

Deng Jing i Liu Xiaojing. (2018). Deepening the "16+1 cooperation" relationship to foster the new growth pole of Sino-EU Trade. China - CEE Institute Working Paper, No. 13, 22 czerwca.

EEAS. (2016). EU - China 2020. Strategic Agenda for Cooperation. Pozyskano z: https:// eeas.europa.eu /sites/eeas/files/20131123.pdf.

Godemont, F. i Vasselier, A. (2017). China At the Gate. Anew Power Audit of EU - China Relations. ECFR, grudzień. Pozyskano z: https://www.ecfr.eu/page/-/China_Power_Audit. pdf.

Góralczyk, B. (2017). China's interest in Central and Eastern Europe: enter the dragon. European View, 16, czerwiec.

Góralczyk, B. (2017). Wschodnioazjatycki model rozwojowy - państwo rozwojowe. W: J. Yifu Lin, A.Z. Nowak (red.), Nowa Ekonomia Strukturalna wobec krajów mniej zaawansowanych. Warszawa: Wydawnictwo Wydziału Zarządzania UW.

Góralczyk, B. (2018). Wielki Renesans. Chińska transformacja i jej konsekwencje. Warszawa: Wydawnictwo Naukowe Dialog.

Góralczyk, B. (red.). (2009). Polska - Chiny: wczoraj, dziś, jutro. Toruń: Wydawnictwo A. Marszałek.

https://cen.acs.org/business/petrochemicals/BASF-considering-10-billion-investment/96/ web/2018/07 (16.07.2018).

https://global.handelsblatt.com/politics/eu-ambassadors-beijing-china-silk-road-912258 (20.07.2018).

https://www.bankier.pl/wiadomosc/Eksport-z-Polski-do-Chin-najwyzszy-w-historii-7568470. html (16.07.2018).

https://www.project-syndicate.org/bigpicture/trump-s-trade-war-expands (16.07.2018).

https://www.project-syndicate.org/bigpicture/trump-s-trade-war-expands (16.07.2018).

Huang Pingci Liu Zuokui. (red.). (2017). China - CEEC cooperation and the 'Belt and Road Initiative'. Beijing: China Social Sciences Press/CASS.

Jakóbowski, J., Popławski, K. i Kaczmarski M. (2018). Kolejowy Jedwabny Szlak. Połączenia kolejowe UE - Chiny: uwarunkowania, aktorzy, interesy. Prace OSW, 72, Warszawa, luty.

Joić, S. (2017). How Serbia perceives „The Belt and the Road” Initiative and 16+1 Cooperatio. China - CEE Institute Working Paper, No. 9. Budapest, 15 listopada.

Kironská, K. i Turcsányi, R.Q. (2017). Slovak Policy towards China in the age of Belt and Road Initiative and 16+1 Format. China - CEE Institute Working Paper, No. 2. Budapest, 15 listopada.

Lin Yue. (2018). Economic 'highway' with three speed tracks and destinations between China and CEE. China - CEE Institute Working Paper, No. 14, Budapest, 22 czerwca.

Liu Zuokui. (2017). Europe and the "Belt and Road" Initiative: Responses and risks. Beijing: Paths International Ltd./China Social Sciences Press/CASS.

Maddison, A. (2007). Chinese Economic Performance in the Long Run (2nd edition). OECD, Paris: Development Centre Studies. 
MERICS i Rhodium Group. (2017). Chinese Investment in Europe: record flows and growing imbalances. Joint report by MERICS and Rhodium Group. Berlin: MERICS - Mercator Institute for China Studies, styczeń. Pozyskano z: https://www.merics.org/en/papers-on-china/chinese-investment-europe-record-flows-and-growing-imbalances (15.07.2018).

Oehler-Sincai, I.M. (2018). 16+1, a New Issue in China-EU Relations? China - CEE Institute Working Paper, No 1. Budapest, 22 czerwca.

Pillsbury, M. (2016). The Hundred-year Marathon. China's strategy to replace America as the global superpower. New York: St. Martin's Griffin.

Sarek, Ł. (2017). Chiński dylemat polskiej polityki zagranicznej. Polski Przegląd Dyplomatyczny „Chiński Dylemat”, 3(70), lipiec-wrzesień.

Stanzel, A., Kratz, A., Szczudlik, J. i Pavlićević, D. (2016). China's investment in influence: the future of $16+1$ cooperation. ECFR, grudzień.

Szczudlik-Tatar, J. (2018). Perspektywy format Europa Środkowa - Chiny po szczycie w Sofii. Biuletyn PISM, 91, 13 lipca.

Winter, T. (2016). One Belt, One Road, One Heritage: Cultural Diplomacy and the Silk Road. The Diplomat, 29 marca.

Xi Jinping (2014). The Governance of China. Mainland China: Foreign Languages Press.

Xi Jinping (2018). President Xi Addresses the 2018 Boao Forum for Asia in Hainan, Boa., 11 kwietnia. Pozyskano z: https://www.uscnpm.org/blog/2018/04/11/transcript-presidentxi-addresses-2018-boao-forum-asia-hainan/ (15.07.2018).

Xin Zhang. (2016). Chinese Capitalism and the New Silk Roads. Aspen Quarterly, 4.

Xinhua. (2016). China, Poland lift ties to comprehensive strategic partnership. Pozyskano z: http://www.xinhuanet.com/english/2016-06/21/c_135452132.htm (16.07.2018).

Xinhua. (2017). Xi Jinping's keynote speech at the World Economic Forum. Davos, 27 stycznia. Pozyskano z: http://www.china.org.cn/node_7247529/content_40569136.htm.

Zou Lu. (2018). An Analysis of Germany's Suspicions about „16+1 Cooperation” and China's Possible Countermeasures - From the Perspective of European Integration. China - CEE Institute Working Paper, No. 5. Budapest 22 czerwca. 
